НАЦИОНАЛЬНЫЙ ИССЛЕДОВАТЕЛЬСКИЙ ИНСТИТУТ

МИРОВОЙ ЭКОНОМИКИ И МЕЖДУНАРОДНЫХ ОТНОШЕНИЙ ИМЕНИ Е.М. ПРИМАКОВА

РОССИЙСКОЙ АКАДЕМИИ НАУК

Марина Стрежнева Дарья Руденкова

\title{
ЕВРОПЕЙСКИЙ СОЮЗ:
}

\section{АРХИТЕКТУРА ВНЕШНЕЙ ПОЛИТИКИ}

Москва

ИМЭМО РАН

2016 
УДК 327(4)

ББК 66.4(4)

Стре 84

Серия «Библиотека Национального исследовательского института мировой экономики и международных отношений имени Е.М. Примакова»

Рецензент:

Cтре 84 доктор экономических наук, профессор Ю.А. Борко

Стрежнева М.В., Руденкова Д.Э. Европейский союз: архитектура внешней политики. - М.: ИМЭМО РАН, 2016. - 135 с.

ISBN 978-5-9535-0480-5

DOI: $10.20542 / 978-5-9535-0480-5$

Монография посвящена институциональным и организационным особенностям внешних сношений Европейского союза после вступления в силу Лиссабонского договора 2007 г. о реформе ЕС. На основе анализа торговой политики, политики развития, оказываемой ЕС гуманитарной помощи, политики соседства и «высокой» внешней политики ЕС выявлена специфика способов поведения ЕС на международной арене и изучены основные инструменты (включая санкции), которыми он при этом пользуется.

Стрежнева Марина Вадимовна - доктор политических наук, $\mathrm{PhD}$ (Манчестерский университет, Великобритания), заведующий Сектором ИМЭМО РАН, профессор кафедры интеграционных процессов МГИМО (У) МИД России

Руденкова Дарья Эдуардовна - кандидат политических наук, младший научный сотрудник ИМЭМО РАН

Strezhneva M.V., Rudenkova D.E. European Union: the Architecture of Foreign Policy. Moscow, IMEMO, 2016. - 135 p.

ISBN 978-5-9535-0480-5

The study is devoted to the analysis of institutional and organizational characteristics of the external relations of the European Union since the Treaty of Lisbon (2007) became law. The cases of EU trade and development policies, as well as its humanitarian aid activities, neighbourhood policy and «higher» foreign policy are presented, exposing specific modes of EU policy in the international arena. The key instruments of the EU foreign policy (including sanctions) receive particular attention.

Strezhneva Marina - Doctor of political sciences, PhD in government (Manchester University, UK), Head of Sector, IMEMO, Professor of MGIMO University, Moscow

Rudenkova Daria - PhD in political sciences, Junior Research Fellow of IMEMO

Публикации ИМЭМО РАН размещаются на сайте http://www.imemo.ru

(с) ИМЭМО РАН, 2016

(C) Стрежнева М.В., Руденкова Д.Э., 2016 
ВВЕДЕНИЕ (М. Стрежнева).............................................. 4

Глава 1: ПРИНЦИПЫ И ПРИОРИТЕТЫ (М. Стрежнева). 15

Глава 2: ИНСТИТУЦИОНАЛЬНЫЕ АКТОРЫ .................23

§ 2.1 ИНСТИТУТЫ ЕВРОСОЮЗА ................................................ 23

§ 2.2 ЕВРОПЕЙСКАЯ СЛУЖБА

ВНЕШНЕПОЛИТИЧЕСКИХ ДЕЙСТВИЙ (Д.Руденкова) ........ 32

§ 2.3 СПЕЦИАЛЬНЫЕ ПРЕДСТАВИТЕЛИ (Д. Руденкова) .... 40

Глава 3: ПОЛИТИкИ ....................................................................446

§ 3.1 ТОРГОВАЯ ПОЛИТИКА........................................................46

$\S 3.2$ ПОЛИТИКА РАЗВИТИЯ ..................................................... 52

$\S 3.3$ ГУМАНИТАРНАЯ ПОМОЩЬ............................................ 60

§ 3.4 ЕВРОПЕЙСКАЯ ПОЛИТИКА СОСЕДСТВА ....................65

§ 3.5 ОБЩАЯ ВНЕШНЯЯ ПОЛИТИКА И ПОЛИТИКА БЕЗОПАСНОСТИ ..................................................................... 77

Глава 4: МНОГОСТОРОННОСТЬ (Д. Руденкова) ................86

Глава 5: САНКЦИИ (М. Стрежнева) .......................................... 102

ЗАКЛЮЧЕНИЕ ............................................................................119

ЛИТЕРАТУРА ….......................................................................... 127 


\section{ВВЕДЕНИЕ}

Евросоюз - это политический актор, единственный в своём роде (sui generis). Суверенитет, как и побудительный мотив к внешнеполитическому действию, в нём делят между собой государства-члены и различные институциональные игроки. Поэтому необходимо уточнить, что мы имеем в виду, рассуждая о внешней политике Евросоюза. С одной стороны, у каждого из государств-членов есть свои внешнеполитические приоритеты. С другой стороны, и сам Евросоюз говорит одним голосом при общении с третьими странами и на многосторонних встречах в верхах. Принципы, на которые опирается этот коллективный голос, определены в Лиссабонском договоре - это принципы демократии, верховенство права, универсальность и неделимость прав человека и фундаментальных свобод, уважение человеческого достоинства, принципы равенства и солидарности, а также уважением принципов Устава ООН и международного права. Нет ни одной другой международной организации в мире, в которой на разных уровнях управления взаимодействовало бы столько игроков, как в ЕС, вследствие чего и процесс принятия внешнеполитических решений в ЕС отличается большой сложностью.

В конечном счёте, с внешним миром он общается тремя разными способами:

(1) межправительственным,

(2) с помощью наднациональных институтов,

(3) через отдельные государства-члены ${ }^{1}$.

Между тем термин «внешняя политика» традиционно используется для описания того, как государства выстраивают свои отношения с другими государствами в рамках международной системы. По сути своей данный термин отражает именно государствоцентричный подход даже в том случае, когда его употребляют применительно к отношениям между государствами и другими акторами - такими, как международные организации. При этом, тем не менее, всегда подразумеваются подходы и цели, свойственные государству в его взаимодействии с другими государствами при продвижении своих национальных интересов на мировой арене.

Так как Европейский союз (ЕС) не является государством, в нём отсутствуют централизованная власть и собственные государственные институты, тогда как его внешняя политика отражает, в том числе, общие особенности функционирования его специфических (наднациональных) институтов ${ }^{2}$. Между тем европейские сообщества, из которых вырос Евросоюз, фактически стали участниками международных отношений со времени своего появления в 1950-х годах. Термин «внешние сношения» со временем обрёл в приложении к ЕС вполне определённый смысл, подразумевая внешнюю торговлю, помощь третьим странам и ряд других разрозненных отраслевых «низких» сфер его международной деятельности, которыми занималась Европейская комиссия (Комиссия, ЕК) и которые позднее стали противопоставлять «высокому» измерению его внешней политики.

Последнее зародилось только в 1970-е годы в виде Европейского политического сотрудничества (ЕПС) и сначала имело неформальную основу. Затем ЕПС была формализована в статье 30 Единого европейского акта 1986 г. и получила наименование Общей внешней политики и политики безопасности (ОВПБ) в Маастрихтском договоре 1992 г., учредившем Европейский союз. Ввиду слабостей межправительственной ОВПБ и нежелания государств-членов делегировать на наднациональный уровень те компетенции, которые дали бы возможность такую слабость преодолеть, с 1990-х годов Евросоюз, кроме

${ }^{1}$ Подробнее об этом см.: Abdelal Rawi, Krotz Ulrich. Disjoining Partners: Europe and the American Imperium // Power in a Complex Global System / Ed. by Louis W. Pauly and Bruce W. Jentleson. London: Routledge, 2014.

P. 131-147.

${ }^{2}$ См.: Борко Ю.А. Евросоюз как институциональная система // Мир перемен. 2011. № 2. С. 186-189. 
того, развивает общие стратегии и партнёрства с различными странами и регионами мира, которые можно охарактеризовать как его структурную внешнюю политику ${ }^{3}$.

Последовательность во внешней политике ЕС обеспечивается статьями 3 и 13 Договора о Европейском Союзе. В ст. 3 говорится о том, что Евросоюз должен обеспечить согласованность своих действий на международной арене и что Комиссия и Совет министров ЕС (Совет) должны сотрудничать для того, чтобы такую согласованность обеспечить. Ст. 13 требует, чтобы Совет обеспечивал единство, согласованность и действенность предпринимаемых Союзом акций. Речь идёт о правовом процедурном обязательстве, из которого вытекает политическое действие. Акторы в сфере внешней политики ЕС, действуя в общем поле, обязаны координировать свои разрозненные действия, чтобы обеспечить искомую последовательность.

В центре внимания авторов настоящей работы - нашедшая оформление в Лиссабонском договоре 2007 г. под шапкой «внешних действий Союза» попытка объединить в единую систему ОВПБ и все «экономические» направления его внешней политики - его внешние сношения ${ }^{4}$, которыми продолжает заниматься Комиссия.

Лиссабонский договор вступил в силу в декабре 2009 г. после длившихся в ЕС почти десятилетие конституционных споров. Он не замещает прежние основополагающие договоры, но вносит некоторые важные изменения в Договор о Европейском Союзе (Маастрихтский договор 1992 г. - ДЕС) и Договор о создании Европейского экономического сообщества (Римский договор 1957 г. - ныне Договор о функционировании Европейского Союза - ДФЕС).

Таким образом, наше исследование сосредоточено на анализе институциональной и политико-правовой архитектуры внешней политики Европейского союза в том виде, как она складывается на практике с 2010 г. В данном смысле внешняя политика ЕС взята в широком срезе, включающем и её «высокую», и её «низкую» составляющую. Мы относим к ней не только ОВПБ, включая Общую политику безопасности и обороны (ОПБО), но и общую торговую политику, сотрудничество в сфере содействия международному развитию, гуманитарную помощь, политику соседства. Устройство каждой из них будет подробнее рассмотрено на этих страницах. Однако за пределы нашего непосредственного внимания вынесены внешние аспекты внутренних компетенций ЕС (сельское хозяйство, рыболовство, транспорт, экономическая и монетарная, экологическая и энергетическая политики, миграция).

При наличии общей институциональной архитектуры в конкретных аспектах внешней политики ЕС, понимаемой в широком смысле, отдельные институты и органы выполняют в ней разные функции. Анализ в данном случае выстроен вокруг участия во внешней политике ЕС многочисленных институциональных акторов, включая Верховного представителя по иностранным делам и политике безопасности, одновременно выступающего в роли заместителя председателя Европейской комиссии. В работе подчёркнута сохраняющаяся дуальность (раздвоенность) между ОВПБ и прочими направлениями иностранной политики $\mathrm{EC}$, а также между внутренними и внешними измерениями в его функционировании. Наличие такой раздвоенности признано и в договорном тексте, где оговаривается, что ОВПБ «подчиняется специальным правилам и процедурам» (статья 24(1) ДЕС), по сути - остаётся межправительственной в своей основе. Главная причина сохранения такой раздвоенности - в

\footnotetext{
${ }^{3}$ Общее представление о ней даёт, к примеру, «Глобальная стратегия ЕС по внешней политике и политике безопасности. Общее видение, единое действие: более сильная Европа» 2016 г. (A Global Strategy for the European Union's Foreign and Security Policy. Shared Vision, Common Action: A Stronger Europe. 2016) [Electronic resource]. Mode of access: https://eeas.europa.eu/top_stories/pdf/eugs_review_web.pdf.

${ }^{4}$ Европейский Союз в ХХІ веке: время испытаний / Под ред. О.Ю. Потёмкиной (отв. ред.), Н.Ю. Кавешникова, Н.Б. Кодратьевой. М.: Весь мир, 2012. С. 22.
} 
озабоченности большинства государств-членов защитой собственного суверенитета при наличии общей европейской внешней политики.

Одним из важнейших изменений, которые были введены по Лиссабонскому договору, следует признать формальный отказ от системы трёх опор. Три опоры - это основные направления, между которыми была распределена компетенция Евросоюза по Маастрихтскому договору. К первой (коммунитаризированной) опоре были отнесены главным образом экономические вопросы, где применялось наднациональное регулирование, во вторую вошла межправительственная ОВПБ, в третью - политика в области внутренних дел и правосудия. В Амстердамский договор 1997 г. включили весь пакет Шенгенских соглашений, по которому положения, касающиеся свободного передвижения лиц, были перенесены из третьей опоры в первую. Наличие отдельных опор считалось главным препятствием, которое мешало в проведении согласованной политики ЕС на международной арене. В особенности это чувствовалось при подходе к решению проблем безопасности, где многоплановые угрозы, в качестве реакции на них, требовали мобилизации инструментов, остававшихся в разном подчинении (в национальном или наднациональном). Лиссабонский договор не вполне упразднил эту сложную систему, однако наделил ЕС статусом юридического лица. Это означает, что теперь ЕС вправе вступать в международные отношения во всех сферах без исключения вне зависимости от нюансов, связанных с его компетенцией в разных вопросах.

Вследствие институциональных изменений во внешней политике ЕC после вступления в силу Лиссабонского договора, в том числе ввиду учреждения Европейской службы внешнеполитических действий (ЕСВД), которой мы уделяем особое внимание, были созданы определённые условия для его более последовательных и оттого более действенных шагов на международной арене. Европейская служба внешнеполитических действий была создана в 2011 г. Она функционирует как «министерство иностранных дел ЕС». Во главе ЕСВД стоит Верховный представитель ЕС по иностранным делам и политике безопасности, который одновременно является заместителем председателя Комиссии. В настоящее время данный пост занимает итальянка Федерика Могерини (Federica Mogherini).

ЕСВД порой довольно метко называют «промежуточной» структурой, зависшей гдето на полпути от классической дипломатической службы, которую имеют государства, до наднациональной бюрократии по образу Европейской комиссии ${ }^{5}$, а потому, с точки зрения отказа от системы опор, её появление можно назвать символическим. Глава ЕСВД, т.е., по сути, межправительственной общей внешней политики, одновременно занимает высокий пост в наднациональной Комиссии, курируя европейские политики развития, соседства и торговли, что, хотя и способствует размыванию граней между наднациональными и межправительственными компетенциями и процедурами принятия решений, но не устраняет их грани окончательно ${ }^{6}$.

Как мы видим, Лиссабонский договор теснее сводит вместе две области, которые ранее развивались по отдельности: внешние сношения (торговля, помощь развитию), с одной стороны, и более традиционные измерения внешней политики (ОВПБ/ОПБО), с другой стороны. Тем не менее, произведенная реформа оказалась не до конца последовательной. Правовая природа принципов горизонтального и вертикального согласования имеющих отношение к «высокой» внешней политике решений прежняя. По большому счёту, она и теперь остаётся вне сферы судебной ответственности (за исключением некоторых нюансов, о которых речь впереди) и зависит от меры готовности к сотрудничеству со стороны государств-членов (либо отсутствия таковой).

\footnotetext{
${ }^{5}$ Bátora J. The 'Mitrailleuse Effect': The EEAS as an Interstitial Organization and the Dynamics of Innovation in Diplomacy // Journal of Common Market Studies. 2013. №51(4). P. 598-613.

${ }^{6}$ Erkelens L., Blockmans S. Setting up the European External Action Service: an Institutional Act of Balance // CLEER Working papers. 2012. №1.
} 
По заявлениям Верховного представителя ЕС по иностранным делам Федерики Могерини, Европейский союз, взятый в целом и с учётом международного влияния отдельных его государств-членов, представляет собой сверхдержаву, располагающую уникальными инструментами, которые позволяют справляться с некоторыми из наиболее опасных мировых кризисов ${ }^{7}$. Такая оценка выдаёт желаемое за действительное. Вопреки подобным утверждениям, ЕС не соответствует критериям сверхдержавы в привычном смысле этого слова.

Для традиционной сверхдержавы важно, в частности, обладание военной мощью, тогда как в военном плане возможности ЕС весьма невелики. К тому же у него децентрализованная политическая структура, которая в принципе не позволяет выдерживать единый курс на международной арене, хотя государства-члены и стремятся к тому, чтобы говорить одним голосом. Это подтвердила, например, его реакция на кризис в Ливии ${ }^{8}$, где собственная роль ЕС выразилась в доставке гуманитарной помощи и во введении режима санкций, однако в аспекте безопасности совместные действия Евросоюзу не удались. Как справедливо замечает по этому поводу российский эксперт Николай Кавешников, Верховный представитель зачастую «вынужден произносить обтекаемые фразы, а реальные мероприятия осуществляются на национальном уровне или в рамках ad hoc коалиций, как произошло с военной операцией в Ливии» ${ }^{9}$. Ему вторит немецкий аналитик Штефан Майстер, отмечая, что у Брюсселя нет адекватного военного и политического инструментария и для работы на сирийском направлении: «Это означает, что будет вестись только разговор без каких-либо действий и без европейского единства» ${ }^{10}$.

Уточним, что, поскольку страны ЕС так и не смогли договориться о полномасштабной операции по линии ОПБО, речь в Ливии шла о военно-гуманитарной миссии EUROFOR Libya, которая тоже так и не состоялась ${ }^{11}$. В интервенции в Ливии в результате участвовали самостоятельно Великобритания и Франция при поддержке ряда других европейских стран $\mathrm{HATO}^{12}$, тогда как Германия, вопреки общей политической линии ЕС, воздержалась при голосовании в Совете Безопасности ООН резолюции №1973, санкционировавшей внешнее военное вмешательство в гражданскую войну в Ливии, а Швеция заблокировала одобрение внутри ЕC концепции операций для EUROFOR Libya (в случае её развёртывания именно Швециипришлось бы осуществлять оперативное командование действиями в Ливии Северной боевой группы, для участия в которой уже было выделено, в частности, 1600 шведских военнослужащих).

По поводу военной операции Евросоюза в Сирии речь не идёт. При этом неудовлетворённость ролью ЕС в попытках урегулирования сирийского кризиса сквозит в словах главы Еврокомиссии Жан-Клода Юнкера: «Сегодня нужна европейская стратегия для Сирии. У Федерики должно быть место за тем столом, где обсуждается будущее Сирии,

\footnotetext{
7 Mogherini: 'The EU is a superpower' // EurActiv, 25.02.2015. [Electronic resource]. Mode of access: http://www.euractiv.com/section/global-europe/news/mogherini-the-eu-is-a-superpower/

${ }^{8}$ Подробно см.: Koenig N. The EU and the Libyan Crisis: In Quest of Coherence? // Istituto Affari Internazionali Working Papers, July 2011.

${ }^{9}$ Кавешников Н.Ю. Европейский союз после Лиссабонского договора // Европейский союз в ХХІ веке: время испытаний / Под редакцией О.Ю. Потёмкиной (отв. ред.), Н.Ю. Кавешникова, Н.Б. Кондратьевой. М.: Весь мир, 2012. С. 25.

${ }^{10}$ Цит. по: Субботин Игорь. Коридоры в Алеппо завели в тупик // Независимая газета, 26.10.2016. С. 8.

11 Gomes A. Was Eufor Libya an April fool's joke? // EUObserver, 13.06.2011. [Electronic resource].Mode of access: https://euobserver.com/opinion/32624.

${ }^{12}$ Подробно см.: Журкин В.В. Европейская армия: поражения и победы. М.: Международные отношения, 2012. C. $174-177$.
} 
чтобы Европа могла помочь восстановить мирное сирийское государство и плюралистическое, толерантное гражданское общество» ${ }^{3}$.

В данном случае роль ЕС выразилась в поддержке усилий, которые предпринимались по линии ООН (Евросоюз стал одним из участников женевского мирного процесса), в признании сирийской оппозиции и в оказании существенных объёмов гуманитарной помощи. В Международной группе поддержки Сирии, которая сложилась под совместным руководством США и России и включила в себя 17 стран и 3 международные организации, присутствовали четыре государства - члена Евросоюза (Франция, Великобритания, Германия, Италия), которые, однако, не демонстрировали слаженности в своих подходах, и Верховный представитель Могерини.

ЕС занял жесткую позицию в отношении режима Башара Асада за репрессии против собственных граждан, введя санкции в отношении Сирии. В ответ на подавление антиправительственных протестов ещё в марте 2011 г. он временно прекратил сотрудничество с сирийским правительством по линии Европейской политики соседства (ЕПС) и ввёл «рестриктивные меры» (санкции), которые постепенно расширялись (в конце января 2012 г. в ЕС был принят пакет ограничительных мер в отношении сирийских физических и юридических лиц).

ЕС устами своего Верховного представителя по иностранным делам признавал, что взаимодействие с Москвой важно при разрешении сирийской и ливийской проблем ${ }^{14}$, однако после срыва российско-американских попыток урегулирования осенью 2016 г. в эскалации сирийского конфликта ЕС винит российскую сторону, называя Россию союзником сирийского режима ${ }^{15}$. Тем не менее, особенно ввиду неспособности государств-членов договориться в определении роли России в Сирии и по мерам европейского влияния на российское лидерство в Сирии, его собственная роль в сирийском урегулировании, в конечном счёте, остаётся второстепенной, хотя Евросоюз вполне ощутил тяжесть драмы сирийских беженцев.

Сирийский пример подтверждает, насколько Евросоюз может быть неубедителен в своей международной роли, несмотря на внушительный потенциал. Ведь европейское интеграционное объединение является крупнейшим экономическим союзом (хотя и не достигшим стадии превращения в полномасштабный политический союз). Как экономический союз, он представляет собой гигантский общий рынок, в котором обеспечена гармонизация некоторых ключевых сфер политики. 19 из 28 стран-участниц перешли на единую валюту евро. Торговля подчинена наднациональному регулированию. Однако возможности ЕС на международной арене, его сильные и слабые стороны в качестве международного игрока определяются, главным образом, отмеченными выше структурными особенностями его внешней политики, в том числе чрезвычайно запутанными процедурами принятия решений, что приводит к непоследовательности в его международных действиях.

Эта непоследовательность имеет горизонтальное (рассогласованность действий ЕС по различным направлениям внешних сношений), институциональное (несогласованность в действиях различных европейских институтов) и вертикальное (разнобой между европейским курсом и национальной внешней политикой отдельных государств-членов) проявления.

13 Juncker J.-C. State of the Union Address 2016: Towards a better Europe: a Europe that protects, empowers and defends. Strasbourg, 14 September 2016. [Electronic resource].Mode of access: http://europa.eu/rapid/pressrelease_SPEECH-16-3043_en.htm.

${ }^{14}$ Burchard Hans von der. EU pushes for closer Russia cooperation. Sanctions remain, but EU backs "selective engagement" with Russia to solve conflicts. March 14 2016. http://www.politico.eu/article/eu-pushes-for-closer-russiacooperation-federica-mogherini-vladimir-putin-war-syria/

15 Европейский Совет обсудил отношения с Россией / Представительство Европейского Союза в Российской Федерации, 21.10.2016.[Электронный ресурс].Режим доступа: http://eeas.europa.eu/delegations/russia/12649/----_ru\%20. 
Для уточнения международной идентичности ЕС специалисты прибегают к разным терминам: нормативная сила ${ }^{16}$, структурная сила ${ }^{17}$ или даже (нео)империя ${ }^{18}$. Нормативная сила, которую зачастую приписывают Евросоюзу как глобальному актору ${ }^{19}$, подразумевает его способность влиять на действия и представления других (в том числе его собственных государств-членов) средствами прямого и опосредованного убеждения.

Идея Европы как нормативной силы была предложена в 2002 г. британским учёным Иэном Мэннерсом, который настаивал на состоятельности Евросоюза в вопросе моделирования желаемого устройства международных отношений ${ }^{20}$. В 2009 г. И. Мэннерс писал: «Нормативную силу должны признавать обоснованной в тех принципах, которые она продвигает. Чтобы нормативная мотивация была убедительной или привлекательной, продвигаемые принципы должны считаться легитимными. Кроме того, их нужно внедрять логически последовательно и согласованно» ${ }^{21}$.По словам Мэннерса, нормативная сила отражает способность международного игрока устанавливать, что считается нормальным в мировой политике, а самым важным фактором, определяющим роль ЕС в мире, служит не то, что он делает или говорит, а то, чем он является ${ }^{22}$.

Признание существования нормативной силы в лице Евросоюза предполагает, что имеют место иные, «нормальные» образования, от которых отличается ЕС и которые не соответствуют тому же определяющему критерию. Подразумевается, что они прагматичны и материалистичны в своих целях и политических ориентациях либо же нормативны по природе своей, но не располагают в достаточной степени тем, что необходимо, чтобы настоять на своих предпочтения ${ }^{23}$. Впрочем, приверженцы школы реализма в международных отношениях нередко утверждают, что рассуждения идеалистов о нём как о нормативной силе, гражданской силе ${ }^{24}$ или проводнике мягкой силы ${ }^{25}$, всего лишь призваны скрыть принципиальную слабость ЕС в качестве международного игрока ${ }^{26}$.

Подобные концептуальные разногласия усугубляются тем обстоятельством, что в институциональном плане организация Евросоюза уникальна. Её трудно напрямую сравнивать с тем, что мы наблюдаем даже в его 28 государствах-членах. Так, в отличие от

\footnotetext{
${ }^{16}$ Manners I. Sociology of Knowledge and Production of Normative Power in the European Union's External Actions // Journal of European Integration. 2015. Vol. 37. № 2. P. 299-318.

${ }^{17}$ Keukeleire S., Delreux T. The Foreign Policy of the European Union. Palgrave Macmillan, 2014. 408 p.

${ }^{18}$ Zielonka J. Europe as Empire: The Nature of the Enlarged European Union. Oxford University Press, 2007.

19 Романова Т.А. Евросоюз как нормативная сила и проблемы ее восприятия в России как барьер на пути политико-правового сближения // Вестник Санкт-Петербургского университета. 2011. Сер. 6. Вып. 1. С. 5266 ;
}

Прохоренко И.Л. Организационная теория в анализе глобального управления // Вестник Московского университета. Серия 25. Международные отношения и мировая политика. 2014. № 3. С. 150-173.

${ }^{20}$ Manners I. Normative Power Europe: a Contradiction in Terms // Journal of Common Market Studies. 2002. Vol. 40. № 2. P. 235-258.

${ }^{21}$ Manners I. Sociology of Knowledge and Production of Normative Power in the European Union's External Actions // Journal of European Integration. 2015. Vol. 37. № 2. P. 299-318; Manners I. The EU’s Normative Power in Changing World Politics // Normative Power Europe in a Changing World: a Discussion / Ed. by André Gerrits. Netherlands Institute of International Relations, 2009. P. 12.

${ }^{22}$ Manners I. Normative Power Europe: a Contradiction in Terms. Op. cit., pp. 236, 252.

${ }^{23}$ Wood S. The European Union: a normative or normal power? // European Foreign Affairs Review. 2009. Vol. 14. № 1. P. 116.

24 Этот термин впервые был применён по отношению к Европейскому сообществу в 1970-е годы Франсуа Дюшеном, директором Института стратегических исследований в Лондоне. См.: Duchêne F. The European Community and the Uncertainties of Interdependence // A Nation Writ Large? Foreign-Policy Problems before the European Community / Ed. by H. Kohnstammand W. Hager. London: Macmillan Press, 1973. P. 1-21.

${ }^{25}$ Hill C. Cheques and Balances: The European Union's Soft Power Strategy / Soft Power and US Foreign Policy: Theoretical, Historical and Contemporary Perspectives // Ed. by I. Parmar, M. Cox. London: Routledge,2010. P. 182199.

${ }^{26}$ Rettman A. NATO chief: EU soft power is "no power at all” // EUObserver, 06.05.2013. [Electronic resource]. Mode of access: https://euobserver.com/foreign/120046. 
национальных политических систем, в ЕС нет ни единого президента, ни премьер-министра или даже правительства. Слаженную работу обеспечивают сразу несколько институтов, у каждого из которых свои функции. Самыми главными среди институтов являются Европейская комиссия (ЕК), Европейский парламент (ЕП) и Совет Европейского союза (Совет). Европейскую комиссию, представляющую интересы Евросоюза в целом, нередко именуют правительством ЕС. Это влиятельный бюрократический орган, играющий ключевую роль в управлении интеграционным объединением. У Комиссии больше власти, чем у администраторов большинства международных организаций. Тем не менее, её сходство с национальным правительством обманчиво.

На самом деле в системе Евросоюза ЕК делит исполнительную власть с национальными правительствами, объединёнными в Совет. Европейский парламент, представляющий интересы граждан стран ЕС, выполняет, вместе с тем же Советом, функцию законодательной власти. Они могут отвергать законопроекты либо вносить в них свои поправки. Но ни ЕП, ни Совет не располагают правом законодательной инициативы монополия на законодательную инициативу в ЕС отдана именно Европейской комиссии.

Европейский союз взаимодействует практически со всеми странами, соседними по отношению к нему и далёкими от него регионами, а также с ключевыми международными организациями. Он имеет 139 делегаций в третьих странах и многосторонних институтах (начиная с ООН в Нью-Йорке) по всему мире - и это в дополнение к внушительной сети дипломатических миссий его государств-членов (большее число собственных посольств, чем у ЕС, среди стран ЕС имеют только Франция, Германия и Великобритания). Делегации ЕС наделены статусом дипломатической миссии (до вступления в силу Лиссабонского договора в мире уже насчитывалось свыше 100 представительств Европейской комиссии ${ }^{27}$ ).Кроме того, он поддерживает отношения с многочисленными неправительственными организациями и занимается публичной дипломатией ${ }^{28}$.

Европейский союз проявляет активность в различных сферах глобальной политики. Поэтому повторим, что было бы неправомерным упрощением сводить его внешнюю политику исключительно к ОВПБ и ОПБО, которые являются лишь важными компонентами значительно более разноплановой политики ЕС на международной арене.

Определение адекватных аналитических рамок для изучения столь сложного объекта, как внешняя политика ЕС, - это весьма трудная задача. В течение многих лет концептуальные подходы к внешней политике $\mathrm{EC}$ делились, прежде всего, на межправительственные и наднациональные. Её рассматривали либо как коллективное действие национальных правительств (со всеми вытекающими проблемами координации), либо как поле деятельности наднациональных акторов и институтов (Комиссии, Совета, Европейского парламента \{Парламента, ЕП\}, теперь ещё - ЕСВД). В последнем случае в центре внимания оказывались вопросы делегирования национальными правительствами полномочий наднациональным институтам, концентрация суверенитета на определённом уровне и контроль (национальных правительств как принципалов над наднациональными институтами как их агентами). Но подчиняться такой дихотомии в нашем случае непродуктивно, поскольку нас интересуют обе стороны вопроса. Классические теории слишком сосредоточены либо на межправительственных акторах (либеральный межправительственный подход Э. Моравчика), либо на наднациональных акторах (неофункционализм, федерализм), а нам интересны и те, и другие одновременно.

Сегодня в концептуальном плане Евросоюз обычно рассматривают как многоуровневую, многоакторную систему управления, куда, в качестве её составных частей,

\footnotetext{
${ }^{27}$ В 1954 г. первым открылся информационный офис Европейского объединения угля и стали в Вашингтоне (США).

${ }_{28}$ Duke S. The European External Action Service and Public Diplomacy // Discussion Papers in Diplomacy. Clingendael, Netherlands Institute of International Relations. The Hague, 2013. 44 p.
} 
включены европейские институты и государства-члены. Теория многоуровневого управления ${ }^{29}$ рассматривает интеграцию как процесс, в ходе которого происходит оформление специфической политической системы, где власть и влияние распределены между несколькими уровнями - субнациональным, национальным и наднациональным. Отсюда следует, что внешняя политика ЕС означает нечто большее, нежели просто сумма внешних политик его государств-членов. В то же время она не ограничивается внешнеполитическими действиями институтов ЕС. Она захватывает оба эти измерения, хотя не всё, что делают отдельные государства-члены в плане внешней политики, относится к внешней политике самого ЕС или даже идёт ей на пользу.

Майкл Смит продемонстрировал применимость этой теории при изучении ОВПБ ${ }^{30}$. В своей статье он признал маргинальность и даже ничтожность роли в ней наднациональных институтов, но тем не менее подчеркнул значимость институциональной эволюции внешней политики ЕС, которая из межправительственного джентльменского соглашения с неписаными правилами превратилась в систему формальных и неформальных правовых обязательств, плюс организаций со своими бюджетами, кадрами и постоянными штабквартирами. Подход с позиций многоуровневого управления подчёркивает важность контактов между акторами, которые находятся на различных уровнях (принадлежат к разным юрисдикциям), но он не позволяет ничего сказать о значении различного рода отношений между разными акторами, которые находятся на одном и том же уровне.

По нашим представлениям, для целей настоящего исследования Евросоюз особенно хорошо укладывается в определение комплексной организационной системы публичного сектора, что, как мы считаем, позволяет с успехом применять к нему наработки современной организационной теории ${ }^{31}$, берущей свои начала в социологии. Организационная теория изучает, как складываются отношения между акторами в определённой среде и как институциональная среда влияет на поведение и развитие этих акторов. Работы по организационной теории, получившей развитие в первой половине XX века, часто основывались на практике жизнедеятельности организаций публичного сектора. Поэтому в тот период, да и позднее к её развитию приложили руку политологи, включая таких авторитетных авторов, Джеймс Марч и Йохан Олсен ${ }^{32}$. В центре подхода с позиций организационной теории - идея о том, что понять процесс принятия решений в организации нельзя, если не проанализировать её структурные моменты. Марч и Ольсен ведут речь о таком толковании термина «структура», которое включает не только структуру формальную, но также неформальные и сетевые отношения, социокультурные и когнитивные аспекты организационного устройства.

Хотя подобные структуры не являются самодовлеющими, а индивидуальные агенты сохраняют некоторую свободу рук, их способность принимать решения поставлена в зависимость от «рутинизации практик в структурах и наличия площадок для совместного

\footnotetext{
${ }^{29}$ Hooghe L., Marks G. Multi-level governance and European integration. Lanham, Maryland: Rowman \& Littlefield, 2001.

${ }^{30}$ Smith, M. Toward a theory of EU foreign policy-making: multi-level governance, domestic politics, and national adaptation to Europe's common foreign and security policy //Journal of European Public Policy. 2004.Vol. 11(4). P. 740-758.

${ }^{31}$ Murdoch Z. Organization Theory and the Study of European Union Institutions: Lessons and Opportunities // Organization Studies. 2015. Vol. 36. Р. 1675-1692; Стрежнева М.В. Территориальный и функциональны типы организации политических пространств (в развитие интеграционной теории) // Политическая наука. 2014 . №2. С. 32-43; Прохоренко И.Л. Организационная теория в анализе глобального управления // Вестник Московского университета. Серия 25. Международные отношения и мировая политика. 2014. № 3. С. 150-173; Прохоренко И.Л. Глобальная роль Евросоюза: что и как объясняет организационная теория // Вестник Пермского университета. Серия: Политология. 2015. № 2. С. 5-17.

${ }^{32}$ March J.G., Olsen J.P. The New Institutionalism: Organizational Factors in Political Life // The American Political Science Review. 1984. Vol. 78. № 3. P. 734-749.
} 
принятия решений участниками» ${ }^{33}$. Отсюда следует, что организационные структуры, с точки зрения данной теории, выступают как независимая переменная, а предметносодержательные результаты деятельности организаций - как зависимая переменная.

Важный раздел организационной теории сегодня составляет организационная теория международных институтов (МИ $)^{34}$. Она подсказывает, что специфичная организация МИ может мешать или, напротив, способствовать действенности шагов, предпринимаемых ими, по распространению норм и повышению приверженности этим нормам участников МИ (государств). Более чем сами нормы, ценности, и принципы, которые являются общими для большого числа МИ, их организационная архитектура является важнейшим фактором в определении успеха или провала самого института в преследовании им своих продекларированных и подразумеваемых целей ${ }^{35}$.

Кроме того, в 2000-х годах шведские учёные Горан Арне и Нильс Брунссон разработали на той же базе концепцию метаорганизаций (MO) ${ }^{36}$. Данная концепция отразила серьёзные изменения в устройстве международных организаций, которые произошли с окончанием холодной войны. $\mathrm{C}$ распространением западной либеральной модели межгосударственную кооперацию в таких областях, как обеспечение безопасности, экономического благосостояния, защита окружающей среды, стало легче реализовать. Вследствие этого такие международные организации, как НАТО, ВТО и ЕС, приняли новых членов, а также перешли к правилам, которые можно назвать более инвазивными, нежели прежние. Иными словами, подобные организации превратились в агентов глобального управления, которые неправильно было бы, как встарь, рассматривать всего лишь как арены, на которых свободно действуют представители государств.

Метаорганизацию можно определить как такую организацию, членами которой являются не индивиды, а другие, более мелкие, организации (главным образом государства в качестве примеров были названы Всемирная торговая организация, Европейский союз, $\mathrm{OOH,} \mathrm{Международный} \mathrm{валютный} \mathrm{фонд} \mathrm{и} \mathrm{пр.}{ }^{37}$ ). Арне и Брунссон настаивали, что есть большие теоретические и эмпирические преимущества в том, чтобы со всей серьёзностью отнестись к подобным образованиям как к особой форме организации ${ }^{38}$, представляющей собой ассоциацию государств. Главное преимущество здесь состоит в том, что при таком отношении более выпукло предстаёт фундаментальное отличие МО от более стандартных форм организации. В сравнении с индивидами, организации, составляющие МО (государства), менее управляемы, а потому МО сложнее, нежели стандартной организации, выступать в роли самостоятельного актора.

Пол Дж. Димаджио и Уолтер В. Пауэлл в своей широко известной работе «Новый взгляд на «железную клетку»: институциональный изоморфизм и коллективная рациональность в организационных полях», которая была впервые опубликована в 1983 г.,

\footnotetext{
${ }^{33}$ Peters B.G. Institutional theory // The Sage Handbook of Governance / Ed. by M. Bevir. London: SAGE Publications, 2011. P. 85.

${ }^{34}$ Balding Ch., Wehrenfennig D. An Organizational Theory of International Institutions // Journal of International Organizations Studies. 2011. Vol. 2. № 1. P. 7-27; Barkin J.S. International Organization: Theories and Institutions. London: Palgrave Macmillan, 2006. 185 p.

${ }^{35}$ Duffield J. The Limits of 'Rational Design' // International Organization, 2003. Vol. 57. № 2. P. 411-430.

${ }^{36}$ Ahrne G., Brunsson N. Organizations and Meta-Organizations // Scandinavian Journal of Management. 2005.

Vol. 21. № 4. P.429-249; Ahrne G., Brunsson N. Meta-organizations. Cheltenham: Edward Elgar Publishing, 2008.

200 p.; Ahrne G., Brunsson N. How much do meta-organizations affect their members? // Paper presented at SGIR 7th Pan-European International Relations Conference, Stockholm, 9-11 September 2010. P. 3.; Kerwer D. International organizations as meta-organizations: The case of the European Union // Journal of International Organizations Studies. 2013. № 4. P. 40-53.

37 К примеру, членами ФИФА (Международная федерация футбола), тесно вовлечённой в глобальное спортивное управление, являются национальные футбольные ассоциации.

${ }^{38}$ Ahrne G., Brunsson N. How much do meta-organizations affect their members? // Paper presented at SGIR 7th PanEuropean International Relations Conference, Stockholm, 9-11 September 2010. P. 3.
} 
предложили исключительно полезное для нашего исследования понятие организационного поля $^{39}$, которое подразумевает совокупность организаций, утверждающих признанную область институциональной жизни. Если считать таковой сферу внешней политики Евросоюза, то организациями данного организационного поля для нас выступают как государства-члены (действуя через межправительственные Европейский совет и Совет или самостоятельно), так и вовлечённые в сферу внешней политики наднациональные институты ЕС (Комиссия, Европарламент, Суд). Разные «организации» взаимодействуют и конкурируют друг с другом за влияние, подчиняясь определённой логике и следуя сложносочинённым европейским правилам.

Преимущества выбора некоего организационного поля в качестве объекта изучения связаны с тем, что в результате наше внимание направлено не на какой-то один аспект организационной жизни, но охватывает полную совокупность относящихся к делу акторов, одновременно учитывая связи между ними и меру их структурной эквивалентности друг другу, как и полю в целом. В связи с этим Димаджио и Пауэлл разработали концепцию институционального изоморфизма, настаивая, что он является скорее правилом, нежели исключением.

В социологии изоморфизмом (isomorphism)называют сходство процессов или структуры одной организации с процессами или структурой другой организации, которое может происходить вследствие имитации, под давлением или в ходе самостоятельного развития в условиях одних и тех же ограничений. Данное понятие помогает отразить процесс гомогенизации организационного поля. По словам Хэннана и Фримена, изоморфизм обычно объясняется тем, что неоптимальные для данной среды формы выбраковываются из неё либо ответственные лица в организациях усваивают институциональную норму и соответствующим образом адаптируют свою организацию ${ }^{40}$.

Руководствуясь этой концепцией, можно, в частности, предсказывать, что если одна организация зависит от другой организации, в особенности в плане ресурсов, то это непременно со временем приведёт к повышению сходства первой организации со второй. При имплементации институциональных реформ рациональные акторы модифицируют институты и органы, добиваясь повышения их схожести с организационным полем: тем самым укрепляется легитимность (жизнеспособность) соответствующих институтов ${ }^{41}$.

Организационная теория, представленная в таком виде, идёт в общем русле институциональных подходов в политологии, которые опираются на точку зрения, что «институты имеют значение». Димаджио и Пауэлл утверждают, что в современных условиях, вопреки тому, что в прежние времена говорил Макс Вебер, структурные изменения движимы не необходимостью повышения эффективности институтов, но процессами, которые делают организации более схожими между собой, вследствие чего они вовсе не обязательно становятся более эффективными. Самой главной целью в данном случае является не эффективность, но легитимность (выживаемость) организаций. Идея институционального изоморфизма на самом деле приглашает понаблюдать за тем, как разные по природе организации соревнуются между собой в плане институциональной жизнеспособности на определённой площадке, и кто в итоге побеждает в этом соревновании.

Акторам и организациям приходится искать и определять своё место в заданной институциональной системе, а их роль и влияние в рамках такой системы зависят от

\footnotetext{
${ }^{39}$ Димаджио Пол Дж., Пауэлл Уолтер В. Новый взгляд на «железную клетку»: институциональный изоморфизм и коллективная рациональность в организационных полях //Экономическая социология. Т.11. №1. Январь 2010. C. 34-56.

${ }^{40}$ Hannan M. T., Freeman J. H. 1977. The Population Ecology of Organizations //American Journal of Sociology. 82: 929-964.

${ }^{41}$ Meyer J. W., Rowan B. Institutionalized Organizations: Formal Structure as Myth and Ceremony // American Journal of Sociology. 1977. Vol. 83. N 2. P. 340-363.
} 
«возможностей и ограничений, заложенных во внутренней и внешней среде» ${ }^{42}$ их существования. Так, поскольку внутренняя политика ЕС строится по отраслевому принципу, у Комиссии есть возможность обходить национальные правительства (национальные политические центры) и работать напрямую с национальными администрациями ${ }^{43}$. Соответственно, в области ОВПБ у Комиссии и ЕП тоже возникает порой возможность влиять на принимаемые межправительственные решения окольным путём. Это может происходить двумя способами ${ }^{44}:$ либо Комиссия и/или ЕП работают напрямую с некими акторами на национальном уровне, либо они взаимодействуют с Верховным представителем и её внешнеполитической службой.

В некоторых областях, где ЕС действует как глобальный актор (например, в сфере помощи международному развитию), у ЕСВД, как мы убедились в ходе исследования, своих ресурсов мало либо их нет вообще. Тогда соответствующие задачи в рамках европейской внешней политики решают другие службы, такие как Генеральный директорат ЕК по развитию, или государства-члены, или функция их решения поделена, рассыпана между различными игроками. Таким образом, архитектура внешней политики ЕС на деле остаётся довольно сложной вопреки предпринятым усилиям по её организационному сосредоточению. В частности, если подойти к рассмотрению природы ЕСВД с позиций институционального изоморфизма, то, напрашивается вопрос: о каком сходстве мы можем здесь вести речь в первую очередь - с Комиссией или с национальными дипломатическими службами? Ответить на него нам предстоит на последних страницах своей книги.

Работа включает введения, пять глав и заключение. Первая глава посвящена представлению ценностей, принципов и эволюционирующих приоритетов, образующих основу и каркас провидимой Евросоюзом внешней политики. Во второй главе рассмотрены институты и органы ЕС, относящиеся к числу самых важных организаций организационного поля внешней политики Евросоюза. Третья глава содержит институциональный анализ политик, имеющих отношение к внешней политике Евросоюза в широком её понимании. В четвёртой главе исследовано практическое действие во внешней политике ЕС принципа многосторонности. Пятая глава анализирует широкое применение во внешней политике ЕС такого инструмента, как санкции. В заключении даны выводы, которые позволяет сделать проведенное исследование.

\footnotetext{
42 Olsen J.P. Change and Continuity: An Institutional Approach to Institutions of Democratic Government //European Political Science Review. 2009. Vol.1. № 1. P.25.

${ }^{43}$ Egeberg M. Multilevel Union Administration: The Transformation of Executive Politics in Europe. Houndsmills: Palgrave Macmillan, 2006. 228 p.

44 Подробнее см.: Chou M.H., Riddervold M. The Unexpected Negotiator at the Table: How the European Commission’s Expertise Informs Intergovernmental EU Policies //Politics and Governance. 2015. Vol.3. № 1. P. 6172.
} 


\section{Глава 1 \\ ПРИНЦИПЫ И ПРИОРИТЕТЫ}

Фундамент внешней политики Евросоюза составляют определённые ценности, включая важнейшую ценность поддержания мира, а также базовые ценности человеческих прав и достоинства, свободы, демократии, равенства, справедливости и солидарности. Конечно, эти ценности сами по себе не являются уникальной принадлежностью ЕС или его внешней политики. Речь идёт о том, что Евросоюз определённым образом их интерпретирует, трансформируя такие интерпретации в основные принципы, являющиеся ориентирами для его внешнеполитического курса. Последние, в свою очередь, включают, в том числе, принципы предотвращения конфликтов, принципы кондициональности (для продвижения прав человека, демократии, верховенства права и должного управления), принципы предупреждения и предотвращения в целях экологической модернизации, а также многосторонность и приверженность свободной и регулируемой торговле. Исходя из этого, мы можем судить о внешней политике Евросоюза как принципиально направленной на трансформацию мира в определённом направлении, опирающуюся на веру в прогресс человечества и в значимость парадигмы права.

Одним из способов, которым ЕС пытается обеспечить мирную трансформацию в третьих странах, является применение политической обусловленности (кондициональности). Речь идёт о механизме, посредством которого государства и международные институты пытаются воздействовать на поведение других (обычно более слабых) государств, применяя при этом материальные стимулы. В концептуальном плане кондициональность тесно связана с логикой рационального выбора. В соответствии с этой логикой, акторы, на которых оказывается воздействие (его объекты), рассматриваются как настроенные, прежде всего, на достижение собственной максимальной выгоды ${ }^{45}$. Речь идёт не о том, чтобы одномоментно изменить их предпочтения, а о том, чтобы сначала заставить их переоценить свои выгоды и затраты в конкретной ситуации.

В трактовке ЕС, кондициональность касается соображений о соблюдении в третьих странах прав человека, наличии там должного управления (good governance), функционирующей демократии и верховенстве закона. Соглашения по торговле, сотрудничеству и ассоциации, заключаемые Евросоюзом с третьими странами, условия предоставления помощи на цели развития, дипломатическое признание и перспектива присоединения к ЕС обставляются с его стороны положениями о возможной временной приостановке их действия, что позволяет Евросоюзу реагировать в случае нарушения партнёрами прав человека и демократических принципов. Таким способом ЕС играет на международной арене нормативную роль (распространяет там собственные нормы) с использованием имеющихся в его распоряжении экономических и дипломатических инструментов.

Под нормами в данном случае мы понимаем мировоззренческие принципы и каузальные убеждения, отражающиеся во внешней политике ЕС. Кондициональность и сама по себе является нормой, т.е. определённым стандартом поведения. Между тем у специалистов есть разные трактовки в вопросе о том, зачем Евросоюз продвигает собственные нормы за рубежом. С точки зрения авторов, исповедующих подходы с позиции рационального выбора, это делается ввиду тех выгод, которых ЕС ожидает от применения своих норм в третьих странах (в таком случае его внешнеполитическое поведение следует

\footnotetext{
${ }^{45}$ Kelley J. International Actors on the Domestic Scene: Membership Conditionality and Socialization by International Institutions // International Organization. 2004. Vol.58. Issue 3. P. 425-457.
} 
расценить как рефлексивное и евроцентричное, если не циничное). С позиции конструктивизма Евросоюз продвигает вовне нормы универсального значения. Процесс, в ходе которого он это делает, начинается с сознательного решения, но затем постепенно, по инерции, перемещается в сферу неотрефлексированного, где утрачивается непосредственная циркулярная (циклическая) связь между причиной и следствием предпринятых действий. Наконец, социологический институционализм, который нам ближе всего в методологическом отношении, подсказывает, что Евросоюз продвигает европейские нормы в международной среде, потому что его институты стараются шире распространить собственную модель (институционный изоморфизм, организационная схожесть). По подсказке Димаджио и Пауэлла, они, практически неосознанно или даже машинально, стремятся экспортировать институциональный изоморфизм в качестве выбора по умолчанию.

Но идея обусловленности родилась не в интегрирующейся Европе, а была, скорее, позаимствована ею из экспертной литературы, посвященной деятельности Международного валютного фонда. МВФ предоставляет отдельным странам займы при условии, что их правительства согласны соблюдать определенные макроэкономические ограничения ${ }^{46}$. В середине 1970-х годов похожая концепция проявилась в решении Палаты представителей американского Конгресса, где речь идет о подчинении помощи третьим странам в военной и гражданской областях правилу соблюдения прав человека ${ }^{47}$.

Сначала принцип демократической обусловленности (democratic conditionality) подчинил себе стратегию Евросоюза по продвижения демократии и европеизации в Восточной Европе. Она исходила из гипотезы либерального сообщества, которую, вместе со своими единомышленниками, последовательно развивал в прикладных разработках представитель либерального направления конструкционизма немецкий автор Франк Шиммельфеннинг ${ }^{48}$. Из конструкционистской парадигмы определяющих норм следовало два основных положения. Во-первых, сообщество цивилизованных наций якобы распространяет соответствующие нормы среди своих членов, имеющих общую идентичность. Во-вторых, перспектива формального членства в подобном сообществе содействует уступчивости со стороны претендентов.

Данная стратегия стимулируемой европеизации берет свое начало в решениях Копенгагенского саммита ЕС, состоявшегося в июне 1993 года. Поскольку, в отличие от предшествующих этапов расширения ЕС, в этом случае речь шла о присоединении группы стран, весьма отличавшихся от «старых» членов и по политическому устройству, и по структуре экономики, в Копенгагене были сформулированы критерии, составляющие «порог допуска» для вновь вступающих стран. Оглашенные условия призваны были гарантировать, что в результате расширения ЕС не утратит собственную идентичность (речь шла о жестких условиях, которые не могли быть модифицированы договором о присоединении). Первый из копенгагенских критериев прямо касался стабильности национальных институтов, обеспечивающих демократию, верховенства закона, прав человека, а также уважения и защиты меньшинств. Были выработаны методы скрининга для оценки политической ситуации и структурных условий в странах-кандидатах, появились ежегодные отчёты об их успехах в восприятии aquis communautaire (достижений Сообщества), руководящие

\footnotetext{
${ }^{46}$ Позитивное отношение к данной идее высказывают, например, авторы в статье: Bienen H.S., Gersovitz M. Economic Stabilisation, Conditionality and Political Stability // International Organization. 1985. Vol. 39. № 4. P. 729754; сугубо негативное содержится в книге нобелевского лауреата по экономике Джозефа Стиглица, бывшего вице-президента и главного экономиста Всемирного банка: см. Stiglitz J.E. Globalization and its Discontents. New York, 2002.

${ }^{47}$ См., к примеру, Cohen Stephen B. Conditioning US Security Assistance on Human Rights Practices //American Journal of International Law.1982. Vol. 76. P. 246-279.

48 Schimmelfennig, Frank. International Socialization in the New Europe: Rational Action in an Institutional Environment. European Journal of International Relations 2000. 6(1) 109-139.
} 
указания, целевые ориентиры и приоритеты, на которые им следовало ориентироваться, добиваясь соответствия общим требованиям, формулируемым Европейской комиссией.

Принцип обусловленности и вытекающая из него стратегия подразумевали, что во взаимоотношениях с ЕС третьим странам для получения желаемого нужно добиваться соответствия определенным нормам в собственном государстве. Иногда демократическую обусловленность называли «усилением через поощрение», признавая, что оно особенно хорошо действует в рамках межправительственных переговоров с кандидатами на членство в EC. Нетрудно представить себе, что в отношении стран-кандидатов на членство, где весомым «призом» выступало скорое вступление в ЕС, данная стратегия действительно оказалась эффективна ${ }^{49}$.

Таким образом, речь сначала шла только о позитивной обусловленности. Но оценив эффективность применения стратегии обусловленности, в ЕС, по-видимому, в какой-то момент пришли к выводу, что в ходе переговорного процесса от стран-кандидатов можно было бы добиться и большего. Поэтому, в частности, ЕК впоследствии озвучила подход к управлению переговорным процессом, предполагающий повышенную изощренность в политике ЕС относительно нынешней группы стран-кандидатов, включая Турцию, Хорватию (ныне уже члена ЕС) и другие государства Балкан. Новый подход включил элементы негативной обусловленности, а именно введение критериев для приостановки переговоров о вступлении по отдельным отраслям, что, в качестве своеобразного «наказания», дополнительно стимулировало бы претендентов к проведению экономических и политических реформ, а также декларацию об отсутствии гарантий успешного завершения процесса вступления для новых кандидатов ${ }^{50}$.

Если позитивную кондициональность можно вкратце определить как обещание некоему государству определённых преимуществ в случае выполнения им заданных условий, то негативная кондициональность подразумевает сокращение, приостановление или прекращение действия подобных преимуществ, если это государство такие условия нарушает.

Помимо прочего, процесс восточного расширения Евросоюза выявил серьезное противоречие в его действиях: в то время как соблюдение демократических требований выступало в качестве принципиальной предпосылки для присоединения к Союзу, само расширение осуществлялось без соблюдения правил демократической отчетности.

В тот момент, когда страны-претенденты вступали в формальные переговоры с ЕС, последний в отношениях с ними переходил от косвенного воздействия к прямому вмешательству. От некоторых стран-кандидатов требовали соблюдения еще более жестких стандартов в сравнении с теми, что действовали в отношении «старых» членов ЕС политика конкуренции (competition policy and state aid rules) может послужить в данном отношении впечатляющим примером. Недемократичности, несбалансированности процесса расширения способствовала готовность ряда ассоциированных стран из Центральной и Восточной Европы самим заранее расстаться с национальным суверенитетом в обмен на твердую гарантию последующего вступления.

По завершении восточной стадии расширения, стратегия обусловленности получила дальнейшее развитие в Европейской политике соседства (ЕПС). В ее рамках соседям ${ }^{51}$ формально были предложены привилегированные отношения, построенные на общих

\footnotetext{
${ }^{49}$ Подробнее см.: Schimmelfennig F., Engert S., Knobel H. Cost, Commitment and Compliance: the Impact of EU Democratic Conditionality on Latvia, Slovakia and Turkey // Journal of Common Market Studies. 2003. Vol. 41 . № 3. P. 495-518.

${ }^{50}$ Подробнее см.: Бетчер Б. Турция на пути в Европейский союз // Расширение Европейского союза и Россия / Под ред. О.В. Буториной, Ю.А. Борко. М., 2006, С. 266-280.

${ }^{51}$ Первоначально ЕПС была предложена Алжиру, Белоруссии, Египту, Израилю, Иордании, Ливану, Ливии, Молдавии, Марокко, Палестинской Автономии, Сирии, Тунису и Украине (Россия отклонила такое предложение). В 2004 г. участие в ЕПС было распространено также на Армению, Азербайджан и Грузию.
} 
ценностях (демократия и права человека, верховенство закона, эффективное и демократическое управление, принципы рыночной экономики и устойчивое развитие). Хотя речь не шла о грядущем расширении, и такая перспектива в рамках ЕПС не просматривалась, подразумевались глубокие хозяйственные связи и экономическая интеграция, причем степень взаимной привязки была поставлена в прямую зависимость от степени приверженности страны соседства европейским нормам и стандартам.

Как мы увидим далее, ЕПС импортировала логику процесса восточного расширения в том, что касается кондициональности, без учёта принципиальных различий между Центральной Европой и странами соседства, а именно: отсутствия в случае последних гарантированной перспективы членства в ЕС, особого стремления центрально-европейских стран к «возращению в Европу» и различий в понимании суверенитета и допустимости вмешательства во внутренние дела.

В 2000 году в Котону (Бенин) была заключено соглашение нового типа, объединившее ЕС со странами АКТ (страны Африки, Карибского бассейна и Тихого океана), которое признано важной вехой на пути применения принципов прав человека к сфере международной торговли и развития. В качестве основополагающих принципов в него были включены международные и региональные стандарты в области защиты прав человека, миграции, гендерных вопросов, прав женщин и добросовестной деятельности органов государственного управления (вопросы борьбы с коррупцией). Соглашение требовало соблюдения этих стандартов не только от государств-участников, но и от созданных им договорных органов. Впоследствии политическая кондициональность, чаще всего в форме прекращения или приостановки помощи развитию ${ }^{52}$, стала одним из ключевых инструментов в политике ЕС по отношению к развивающимся странам ${ }^{53}$. Она применялась в качестве реакции на государственные перевороты, нарушения, выявленные в ходе выборов и серьёзные нарушения прав человека ${ }^{54}$. Акцент на негативные меры при определении и концептуализации политической обусловленности постепенно привёл к тому, что Елена Фиерро назвала «автоматическим рефлексом приравнивания кондициональности к санкциям» ${ }^{55}$.

Укажем, что ранее кондициональность вообще не затрагивала отношения Европейского Союза (Сообщества) с развивающимися странами. Его помощь развитию тогда трактовалась как осуществляемая вне политики, а его курс в отношении «третьего мира»как свободный от примет былого колониализма и выгодно отличающийся от своекорыстной политики сверхдержав. Однако фундаментальные подвижки в отношениях между Западом в целом и развивающимися странами за последнее десятилетие внесли в концепт политической кондициональности свои нюансы.

Многие развивающиеся экономики мира существенно поднялись и находятся теперь в статусе стран со средним уровнем дохода. Чем выше их ВВП на душу населения, тем меньше значимость иностранной помощи. Кроме того, Китай является для многих развивающихся стран источником финансов, не обременённых кондициональностью. В таком контексте привязанная к помощи политическая кондициональность перестаёт быть эффективным внешнеполитическим инструментом для ЕС, что заставило ЕС переключиться на продвижение устойчивого развития через заключение торговых соглашений. В области торговой политики ЕС основные принципы кондициональности впервые получили

\footnotetext{
${ }^{52}$ В 1977 г. Европейское сообщество вынуждено было отреагировать на резню в Уганде - впервые, не имея на то никакой правовой основы, оно приостановило предоставление этой стране обещанных средств.

${ }^{53}$ Crawford G. Foreign Aid and Political Reform: A Comparative Analysis of Democracy Assistance and Political Conditionality. Basingstoke, UK/New York: Palgrave, 2001. 293 p.

${ }^{54}$ Hazelzet H. Suspension of Development Co-operation: An Instrument to Promote Human Rights and Democracy? // European Centre for Development Policy Management (ECDPM) Discussion Paper №. 64B. 2005. 23 p.

${ }^{55}$ Fierro E. The EU's Approach to Human Rights Conditionality in Practice. The Hague: Kluwer Law International, 2002.
} 
оформление в 1995 г. в рамках Общей системы тарифных преференций (см. ниже), предоставляемых развивающимся странам.

В настоящее время политическая обусловленность отнюдь не утратила своей актуальности в сфере внешних сношений Евросоюза. Но её характер, качество, цели и используемые механизмы стали более широкими и разнообразными. В частности, следует констатировать нарастающее использование Евросоюзом на международной арене такого инструмента, как санкции, или, как их чаще называют в самом EC, рестриктивных мер, выступающих в его репертуаре в качестве наиболее доступной ему формы квазисиловой дипломатии.

Если говорить о многосторонности, то до 1990-х годов это понятие не относилось к числу ключевых и наиболее проработанных в теории международных отношений. Однако сразу по завершении холодной войны общий энтузиазм по поводу международных институтов вызвал заметный рост числа теоретических работ по многосторонности. Так, в определении Роберта Кеохейна ${ }^{56}$, речь идёт о «практике координации национальных курсов в группах по три или более государств, осуществляемой от случая к случаю или посредством институтов», принимающих форму международных режимов либо бюрократических организаций. Впрочем, Джон Рагги вскоре раскритиковал это определение как поверхностное и игнорирующее качественное измерение данного явления. Для него многосторонность означала координацию отношений между тремя или большим числом государств - в согласии с определёнными принципами, подчиняющими себе отношения между этими государствами. Она непременно влечёт за собой институционализацию, но часто наблюдается в отсутствие международных организаций, которые «появились относительно недавно и пока не обрели существенного значения» ${ }^{57}$. Более современное определение многосторонности звучит следующим образом: это «три или более акторов, вовлечённых в добровольное и, по большей части, институционализированное международное сотрудничество, подчинённое нормам и принципам, с правилами, которые, в общем и целом, в равной степени применяются ко всем государствам» ${ }^{58}$.

О преимуществах «эффективной многосторонности» Евросоюз впервые заявил в Европейской стратегии безопасности (ЕСБ) 2003 г., где читаем: «В мире глобальных угроз, глобальных рынков и глобальных массмедиа наши безопасность и благосостояние во все большей мере зависят от эффективности многосторонней системы» ${ }^{59}$. В Лиссабонском договоре (ст. 21 ДЕС) записано, что Союз добивается «развития международной системы, основанной на усиленном многостороннем сотрудничестве и хорошем глобальном управлении». «Эффективная многосторонность», краеугольными камнями которой должны выступать ООН и ВТО, была представлена в этом документе как путь к глобальному управлению и управляемой многополюсности. Она подразумевала действенность международных организаций, режимов и договоров в противостоянии глобальным вызовам и угрозам, ведь вопросы международной значимости предпочтительно решать не от случая к случаю в кругу отдельных стран, а создав для этого общую систему правил и институтов, которые признают большое число государств.

«Эффективная многосторонность» должна была к тому же опереться на прочное региональное управление, чем подчеркивалась значимость продвижения проектов

\footnotetext{
${ }^{56}$ Keohane R.O. Multilateralism: an Agenda for Research //International Journal. 1990.Vol. 45. № 4. P. 731.

${ }^{57}$ Ruggie J.G. Multilateralism: the Anatomy of an Institution // International Organization. 1992. Vol. 46. № 3. P. 568 .

${ }^{58}$ Peterson J., Bouchard C. Making Multilateralism Effective: Modernising Global Governance // Multilateralism in the 21st Century. Europe's Quest for Effectiveness / Ed. by C. Bouchard, J. Peterson, N. Tocci. London, New York: Routledge, 2014. P. 18.

${ }^{59}$ A Secure Europe in a Better World. European Security Strategy (ESS) // The European Council. Council of the European Union. 2003. P. 10. [Electronic resource]. Mode of access: https://www.consilium.europa.eu/uedocs/cmsUpload/78367.pdf.
} 
региональной интеграции по всему миру согласно представлению о том, что европейский интеграционный проект - это, по сути, воплощение идеи международного порядка, построенного на общих правилах. В 2008 г. был обнародован доклад о ходе имплементации ЕСБ $^{60}$, где утверждалось, что двусторонние партнерства ЕС с ключевыми третьими странами преследуют цель выстраивания «эффективной многосторонности». Как следовало из Европейской стратегии безопасности 2003 г, к числу стратегических партнёров ЕС на тот период были отнесены США, Россия (единственная европейская страна в этом списке), Япония, Китай, Канада и Индия. Такие страны, как Австралия, Индонезия и Турция, являясь стратегическими партнёрами Евросоюза де факто, не имеют соответствующего формального статуса. Остальные шесть стратегических партнёрств (с Китаем, Индией, Бразилией, Мексикой, Южно-Африканской Республикой и Республикой Кореей) были учреждены в период с 2003 по 2010 гг. уже после принятия ЕСБ.

Все вышеперечисленные стратегические партнёры ЕС входят в G20. Евросоюз является крупнейшим торговым визави для шести из названных десяти стран: для Бразилии, Китая, Индии, России, Южной Африки и США. Подход ЕС к стратегическим партнёрствам включает три элемента: 1) торговля и инвестиции; 2) продвижение многосторонности и укрепление международного сотрудничества; 3) коллективные обязательства в вопросах безопасности.

Идея стратегического партнёрства подразумевает долговременные взаимовыгодные отношения и совместное принятие решений. Особую важность имеют два критерия: нормативная конгруентность (но к далёким от Европы растущим странам, начиная с КНР, в этом вопросе Брюссель относится заметно снисходительнее, нежели к России) и значимость отношений с ними для ЕС в плане экономики и финансов. Предлагая стратегические партнерства в начале 2000-х годов, Европейская комиссия (ЕК) в первую очередь имела в виду именно укрепление глобальной роли Евросоюза в экономике, а также обеспечение экономической безопасности ЕС. Ежегодные (проводимые дважды в год в случае РФ) саммиты, министерские встречи и отраслевые диалоги между представителями ЕС и указанных стран проходили регулярно. Впрочем, в случаях с Бразилией, Китаем, Россией ${ }^{61}$, Индией и Южной Африкой это не помогло преодолеть существенные расхождения во взглядах и интересах.

В целом облик Евросоюза, который он сам стремится транслировать вовне, в духе английской школы в теории международных отношений ${ }^{62}$, объединяет кантианские условия для «вечного мира» ${ }^{63}$ - демократические режимы внутри стран, международный договор демократических стран и космополитическое право - с гроцианской верой в позитивное влияние регулирования и международного права. Упор на правовое регулирование внутри Евросоюзав его внешней политике находит выражение в том, что он старается продвигать

\footnotetext{
${ }^{60}$ Report on the Implementation of the European Security Strategy Providing Security in a Changing World // The European Council. Council of the European Union. Brussels, 11 December 2008. [Electronic resource]. Mode of access: https://www.consilium.europa.eu/ueDocs/cms_Data/docs/pressdata/EN/reports/104630.pdf

${ }^{61}$ В настоящее время Евросоюз не рассматривает Россию как своего стратегического партнёра. См.: Резолюция Европарламента: Россия больше не является стратегическим партнером Евросоюза. 9 июня 2015. URL: http://www.rosbalt.ru/main/2015/06/09/1407056.html. См. также: Борко Ю.А. Россия - Евросоюз: от стратегического партнёрства к холодному миру // Европейская безопасность: события, оценки, прогнозы. 2013. №30. С. 4-10; Борко Ю.А. Россия - Евросоюз: состоялось ли стратегическое партнёрство? // Современная Eвропа. 2014. №33. C. 4-8.

62 Миронов В.В. «Международный порядок» Хедли Булла и английская школа теории международных отношений // Вестник Омского университета. 2011. № 3.С. 108-114; Миронов В.В. «Новое Средневековье» в концепциях представителей английской школы теории международных отношений // Вестник Омского университета. Серия «Исторические науки». 2015. № 2 (6). С. 23-29.

${ }^{63}$ Саликов А.Н. Интерпретация идей трактата «К вечному миру» И. Канта в современной либеральной теории демократического мира // Кантовский сборник. 2012. №4 (42). С. 42-49.
} 
усилия по созданию и укреплению многосторонних регулирующих органов на международной и глобальной арене.

В Маастрихтском договоре были сформулированы руководящие принципы действий Евросоюза в сфере внешних сношений, которые включили:

- защиту его ценностей, основополагающих интересов, безопасности, независимости и целостности;

- консолидацию и поддержку демократии, верховенства права, прав человека и принципов международного права;

- заботу о сохранении мира, предотвращении конфликтов и укреплении международной безопасности;

- содействие устойчивому экономическому, социальному и экологическому развитию развивающихся стран (при ликвидации нищеты в качестве первостепенной задачи);

- поощрение интеграции всех стран в мировую экономику, в том числе путём последовательного устранения ограничений в международной торговле;

- помощь в развитии международных мер по сохранению и улучшению качества окружающей среды;

- содействие населению, странам и регионам, пострадавшим от природных или техногенных катастроф;

- продвижение международной системы, основанной на прочном международном сотрудничестве и надёжном глобальном управлении.

Европейская стратегия безопасности 2003 г. ${ }^{64}$, в свою очередь, позволяет судить об основах внешнеполитической доктрины $\mathrm{EC}$, а именно:

1. ЕС следует предпринимать все необходимые шаги в ответ на многочисленные глобальные вызовы и угрозы безопасности, включая региональные конфликты, распространение оружия массового уничтожения, терроризм, недееспособность государства, организованную преступность, опасные болезни и разрушительную бедность (Доклад о ходе имплементации ЕСБ-2003, выпущенный в 2008 г. ${ }^{65}$, добавил к этому списку морское пиратство, угрозы кибернетической безопасности, энергетической безопасности и климатические изменения, а Глобальная стратегия 2016 г. ${ }^{66}$, в качестве вызовов, выделяет также демографию, миграцию, гибридные угрозы и охрану внешних границ);

2. ЕС следует сфокусироваться на выстраивании региональной безопасности в зоне «европейского соседства», куда отнесены Балканы, Кавказ, Средиземноморский регион и Ближний Восток;

3. В долговременной перспективе ЕС должен преследовать цель создания основанного на правилах, многостороннего мирового порядка, в котором международное право, мир и безопасность обеспечены сильными региональными и глобальными институтами (в упомянутом выше Докладе 2008 г. утверждалось, что цель выстраивания эффективной многосторонности преследуют двусторонние партнёрства ЕС с ключевыми третьими странами).

В Евросоюзе исходят из того, что с такими угрозами и вызовами нельзя справиться исключительно военными средствами. Адекватный ответ на них требует сочетания военных,

\footnotetext{
${ }^{64}$ A Secure Europe in a Better World. European Security Strategy (ESS). 2003. [Electronic resource]. Mode of access: https://www.consilium.europa.eu/uedocs/cmsUpload/78367.pdf.

${ }^{65}$ Report on the Implementation of the European Security Strategy - Providing Security in a Changing World. Brussels, 112 December $2008 . \quad 12 \quad$ p. https://www.consilium.europa.eu/ueDocs/cms_Data/docs/pressdata/EN/reports/104630.pdf.

${ }^{66}$ A Global Strategy for the European Union's Foreign and Security Policy. Shared Vision, Common Action: A Stronger Europe. 2016) [Electronic resource]. Mode of access: https://eeas.europa.eu/top_stories/pdf/eugs_review_web.pdf.
} 
политических и экономических инструментов. При этом главная сила Евросоюза связана как раз с его богатым арсеналом гражданских средств, или инструментов «мягкой силы» ${ }^{67}$.

Об уточненных приоритетах внешнеполитических действий Евросоюза мы можем судить на основании обнародованной в конце июня 2016 г. Глобальной стратегии ${ }^{68}$. Эти приоритеты включают:

1. обеспечение безопасности самого Евросоюза, граждан ЕС и его территории ввиду угрозы терроризма, гибридных угроз, экономических потрясений, климатических изменений и уязвимости в энергетической сфере;

2. укрепление жизнестойкости государства и общества в странах к югу (вплоть до Центральной Африки) и к востоку (до Центральной Азии включительно) от границ ЕС;

3. комплексный подход к урегулированию конфликтов с использованием всех возможностей ЕС;

4. поддержку добровольных форм регионального управления;

5. приверженность глобальному порядку, основанному на международном праве ради сдерживания политики баланса сил, эффективное глобальное управление.

Глобальная стратегия Евросоюза в области внешней политики и политики безопасности, разработанная под руководством Верховного представителя Ф. Могерини, была представлена во время саммита ЕС в Брюсселе в июне 2016 г. В документе объёмом в 56 страниц понятие «Европа» чаще всего предстаёт синонимом Европейского союза. Там подтверждено, что именно ценности по-прежнему являются главной сущностной чертой Европы, воплощённой в ЕС. В то же время новая стратегия скромнее ЕСБ 2003 г. в заявленных амбициях. В Глобальной стратегии 2016 г. впервые признаётся, что у ЕС есть «жизненные интересы», но «между национальными и европейскими интересами нет противоречия». В качестве его жизненных интересов определены: безопасность граждан ЕС и его территории, благосостояние всех граждан; демократия; основанный на правилах глобальный порядок для сдерживания политики баланса сил.

Заметно, что Евросоюз более не настаивает на активной демократизации в собственных действиях, что отражает его вновь обретённую позицию принципиального прагматизма, подразумевающую преследование собственных интересов в сочетании с отстаиванием принципов международного права ${ }^{69}$. Но соседство Евросоюза в данном случае, как мы видим, трактуется широко: оно включает Центральную Азию и Центральную Африку.

Идеал нормативной, основанной на ценностях внешней политики ЕС сложился в контексте больших ожиданий по окончании холодной войны, которые отразила ЕСБ 2003 г., по поводу распространения в мире демократии и верховенства права. Но европейские усилия по продвижению демократии и прав человека в мире не имели повсеместного убедительного успеха, в особенности в зоне соседства (в качестве отдельных позитивных примеров в ЕС упоминают Тунис и Грузию), в силу чего роль ценностей и норм во внешней политике ЕС потребовала известной переоценки.

\footnotetext{
${ }^{67}$ Джозеф Най, автор популярного у специалистов концепта мягкой силы, подразумевает под нею способность международных игроков достигать своих внешнеполитических целей, опираясь не на принуждение, а на позитивное притяжение (attraction), на ценности, культуру, надёжные институты и политику, которую международное сообщество признаёт как легитимную и заслуживающую доверия. См.: Nye J. S., Jr. Soft Power: The Means to Success in World Politics. New York: Public Affairs, 2004. 191 p.

${ }^{68}$ A Global Strategy for the European Union's Foreign and Security Policy (2016) Shared Vision, Common Action: A Stronger Europe. Available at: <http://eeas.europa.eu/statements-eeas/2016/160628 02 en.htm>.

${ }^{69}$ Biscop Sven. The EU Global Strategy: Realpolitik with European Characteristics // ESecurity Policy Brief. 2016. № 75. June 2016. Р. 1-6. См. также: Fallon T. Europe's 'Principled Pragmatism' on the South China Sea // RUSI. 12.07.2016. [Electronic resource]. Mode of access:https://rusi.org/commentary/europe\%E2\%80\%99s$\%$ E2\%80\%98principled-pragmatism $\%$ E2\%80\%99-south-china-sea.
} 


\section{Глава 2 \\ ИНСТИТУЦИОНАЛЬНЫЕ АКТОРЫ}

\section{§ 2.1 ИНСТИТУТЫ ЕВРОСОЮЗА}

Сторонники «нового межправительственного подхода» ${ }^{70}$ и идеи «межправительственного союза» ${ }^{71}$ склонны полагать, что, при соблюдении некоторых условий, более глубокой интеграции в ключевых сферах деятельности Евросоюза, включающих внешнюю политику и политику безопасности, можно достичь и без упора на наднациональность. В этом они усматривают «интеграционный парадокс» ${ }^{72}$, поскольку в данном случае не используется традиционный метод сообщества (community method).Институты EC, которые представляют правительства государств-членов - это Европейский совет и Совет министров ЕС (Совет). Европейский совет осуществляет руководство в сфере ОВПБ. На Совет (как и на Комиссию) возложены определённые задачи, в выполнении которых они следуют его указаниям.

\section{ЕВРОПЕЙСКИЙ СОВЕТ}

Европейский совет, который собирается несколько раз в год, состоит из глав национальной исполнительной власти. На его заседаниях также присутствуют председатель Европейского совета (в настоящее время это Дональд Туск), председатель Европейской комиссии (ЖанКлод Юнкер) и глава Европейского центрального банка (Марио Драги). Председатель Европейского совета готовит его заседания, председательствует на них и призван облегчать достижение консенсуса. Постоянный председатель Европейского совета обеспечивает внешнее представительство Евросоюза. Он имеет также право созвать чрезвычайное заседание Европейского совета, если того требуют международные события.

Европейский совет определяет общую политическую линию Евросоюза, выявляет его стратегические интересы и ставит перед ним определённые задачи. В том, что касается внешней политики, Лиссабонский договор наделил Европейский совет ролью стратегического лидера. В статье 22 ДЕС говорится о том, что «Европейский совет устанавливает стратегические интересы и цели Союза», причём его решения на данный счёт касаются не только ОВПБ, но и «других сфер, относящихся к внешнеполитической деятельности», т.е. по всему спектру международных действий ЕС. В настоящее время роль Европейского совета во внешней политике ЕС заметно возросла. Но это не слишком способствует её сплочённости, последовательности и смелости, поскольку национальные премьер-министры не склонны оценивать долговременные последствия принимаемых ими решений и оценивают ситуацию, прежде всего, сквозь призму собственной актуальной внутриполитической ситуации каждый и исходя из расклада, складывающегося в отношении предстоящих национальных выборов. Европейский совет в итоге всегда работает в авральном режиме и почти исключительно сосредоточен на острых кризисных ситуациях, а потому, по большому счёту, с ролью стратегического лидера во внешней политике, которой его наделили, не справляется ${ }^{73}$.

\footnotetext{
${ }^{70}$ Puetter U. The European Council and the Council: New Intergovernmentalism and Institutional Change. Oxford: Oxford University Press, 2014. 288 p.

${ }^{71}$ Fabbrini S. From Consensus to Domination: The Intergovernmental Union in a Crisis Situation // Journal of European Integration. 2016.Vol. 38. № 5. P. 587-599.

${ }^{72}$ Bickerton J., Hodson D., Puetter U. The New Intergovernmentalism: European Integration in the Post-Maastricht Era // Journal of Common Market Studies. 2014. Vol.53. № 4. P. 703.

${ }^{73}$ Stefan Lehne. Are Prime Ministers Taking Over EU Foreign Policy? February $16,2015$. http://carnegieeurope.eu/publications/?fa=59070.
} 


\section{COBET}

В Совет по иностранным делам (одна из десяти конфигураций Совета министров ЕС), который собирается ежемесячно, входят национальные министры, ответственные за внешнюю политику, а также (в зависимости от конкретной повестки) за внешнюю торговлю, оборону и политику развития. Но в практическом плане он более не является главной инстанцией в принятии ключевых внешнеполитических решений, несколько отступив в тень на фоне Европейского совета, с одной стороны, и ЕСВД, с другой стороны.

Постоянным председателем на заседаниях Совета является Верховный представитель по иностранным делам. Но когда Совет по иностранным делам обсуждает вопросы общей торговой политики ЕС, то во главе стола сидит представитель того государства, которое в данное время (на очередные полгода) председательствует в Совете. Совет ЕС по иностранным делам принимает решения (голосует) по внешнеполитическим акциям и позициям. Решения по линии ОВПБ принимаются единогласно - но в отношении некоторых их аспектов допускается квалифицированное большинство при голосовании. В определённых случаях (например, когда предлагается осудить некое третьего государство) государство-член может воздержаться при голосовании по определённому внешнеполитическому действию ЕС, не блокируя его. Лиссабонским договором такое конструктивное воздержание (constructive abstention) предусмотрено и для Совета (когда он должен голосовать единогласно), и для Европейского совета. Например, этот механизм был использован в феврале 2008 г., когда Кипр воздержался при принятии в Совете решения, учреждающего миссию EULEX в Косово. Кипром было указано при этом, что Косово не имеет полного международного признания в качестве суверенного и независимого государства, а потому соответствующая миссия ЕС не получит мандата Совета Безопасности $\mathrm{OOH}^{74}$.

В области ОВПБ, как и в Евросоюзе в целом, Совет одновременно выступает и в законодательной и в исполнительной роли. Такую ситуацию наблюдатели не без некоторого основания именуют «делегированием, направленным на сговор» (collusive delegation). Ведь в данном случае национальные правительства (исполнительная власть национального уровня) создали межправительственную политику в таких формах, которая позволяет им избегать национального парламентского контроля, но при этом не обеспечили демократический контроль над собственными внешнеполитическими действиями на наднациональном уровне $^{75}$.

\section{КОМИССИЯ}

Пик бесспорного могущества Европейской комиссии в институциональной системе пришёлся на те десять лет, когда во главе ЕК стоял Жак Делор (1985-1995). После вступления в силу Лиссабонского договора и связанных с ним институциональных реформ ЕК, по признанию специалистов, несколько потеряла в своём прежнем влиянии из-за произошедшего перераспределения власти между институтами. Принято считать, что во внешней политике это выразилось в наибольшей степени. Но такое мнение следует признать неточным, поскольку во всех сферах внешних сношений Евросоюза за пределами ОВПБ

\footnotetext{
74 Среди членов ЕС пять стран (Греция, Испания Кипр, Румыния и Словакия) не признали независимость Косово.

${ }^{75}$ Lalon Nathaniel. Accountability in the EU's Common Foreign and Security Policy: Lessons from the Common Commercial Policy // The Role of Parliaments in European Foreign Policy: Debating on Accountability and Legitimacy / Barbe Esther and Herranz, Anna (eds.) Barcelona, Foreign Policy Governance in Europe Research Network (FORNET), 2005. P. 39.
} 
позиции Комиссии на самом деле не только сохранились, но и (в ряде случаев) даже несколько укрепились.

На самом деле Европейская комиссия остаётся одним из важнейших акторов в сфере внешних сношений Евросоюза, хотя институциональные изменения, внесённые по Лиссабонскому договору, действительно подсократили, по крайней мере формально, её влияние в сфере ОВПБ. Комиссия по-прежнему играет важную роль в сфере внешних сношений Евросоюза. Она ответственна за выработку проекта бюджета ЕС, включая средства, которые выделяются по линии ОВПБ (всего на обеспечение внешних сношений ЕС на период 2014-2020 гг. из общего бюджета выделено 66262 млн. евро, или 6,1\% от общей суммы), на 2016 г. - 9143 млн. евро). В сфере непосредственной ответственности Комиссии остаётся согласуемое с ЕСВД распределение средств ЕС, выделяемых по линии политики соседства, политики развития и предоставления третьим странам гуманитарной помощи. Кроме прочего, Комиссия надзирает и за тем, как тратятся средства, выделяемые непосредственно ЕСВД (в

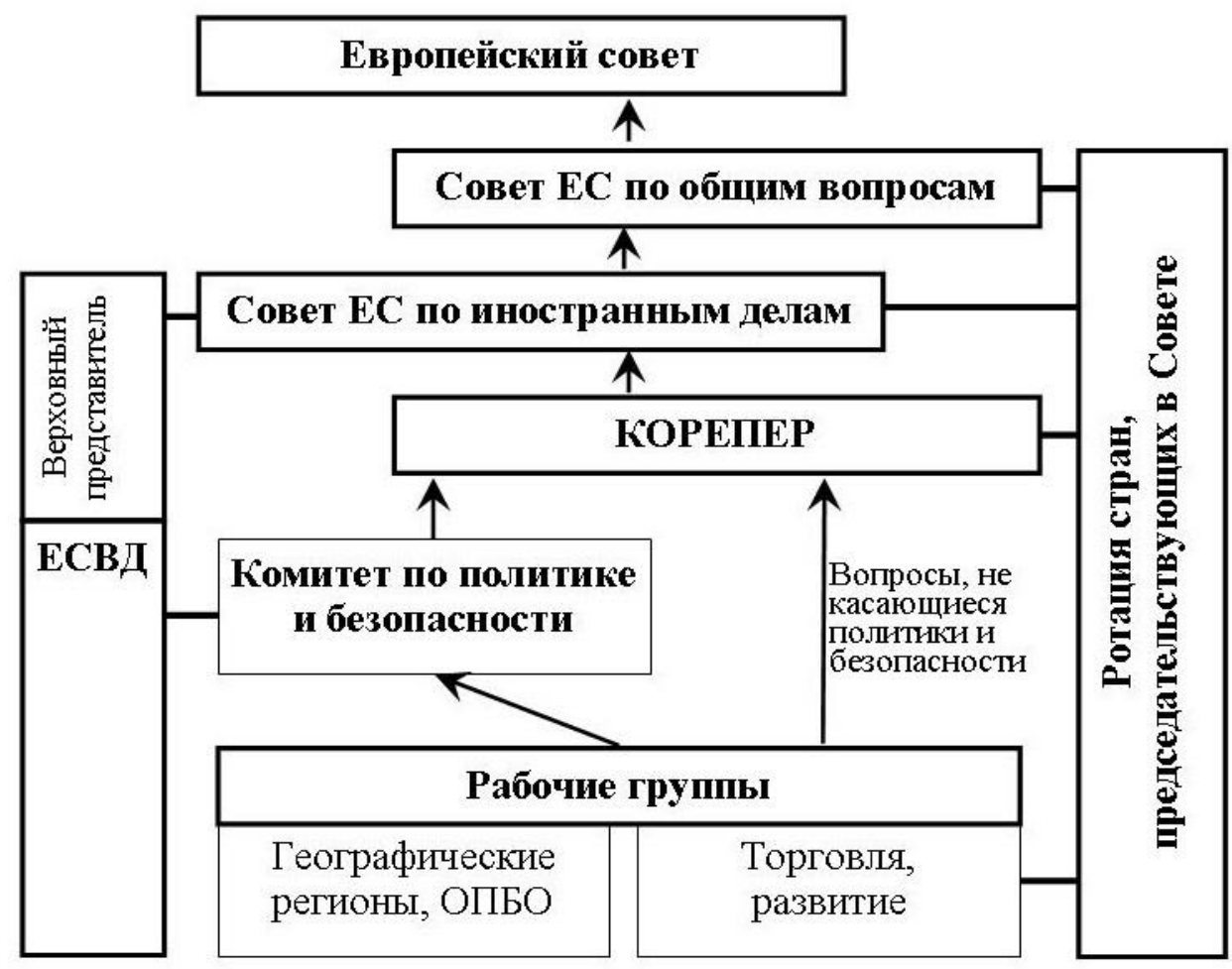

Схема 2-1. Принятие решений в Совете по иностранным делам

2015 г. бюджет ЕСВД составил всего 602.8 млн. евро плюс от Комиссии Служба получила ещё 204.7 млн. евро в компенсацию расходов по линии функционирования представительств ЕС по всему миру).

Согласно формулировке, которая содержалась в Маастрихтском договоре, Комиссия была полностью ассоциирована с Общей внешней политикой и политикой безопасности. Но теперь прежний Генеральный директорат Комиссии по внешним сношениям (DGRELEX) влили в ЕСВД, а прежние делегации Комиссии за рубежом стали представительствами (миссиями) Европейского союза. 
Комиссия сохранила право (совместно с Верховным представителем) предлагать Совету проекты решений, касающихся действий ЕС в международной среде. Служба по внешнеполитическим инструментам (Service for Foreign Policy Instruments - FPI), отвечающая за оперативные расходы ${ }^{76}$, остаётся структурным подразделением Комиссии, но должна держать отчёт непосредственно перед Верховным представителем в его/её роли как первого заместителя председателя Комиссии. Служба должна поддерживать достижение целей внешней политики и политики безопасности ЕС в том виде, как они сформулированы в статье 21 ДЕС, в особенности в том, что касается обеспечения мира и предотвращения конфликтов, а также помогать проецировать интересы ЕС и его позитивный облик по всему миру.

Работая в тесной связке с Верховным представителем, ЕСВД и представительствами (посольствами) ЕС, она выполняет следующие задачи:

- исполнение бюджета ОВПБ;

- исполнение мер по реагированию на кризисы и их предотвращению, которые финансируются с помощью Инструмента по обеспечения стабильности и мира (ранее Инструмент по обеспечению стабильности - 2.3 млрд. евро на 2014-2020 гг., 339 млн. в 2016 г.);

- применение Инструмента партнёрства, предназначенного для продвижения стратегических интересов Евросоюза по всему миру (954.8 млн. евро в 2014-2020 гг., 126 млн. в 2016 г.), включая решение проблем по борьбе с изменением климата, энергетической безопасности, а также в поддержку внешнего измерения усилий ЕС по повышению своей конкурентоспособности и по развитию научных исследований;

- применение Инструмента по сотрудничеству с промышленно развитыми странами (в особенности в Северной Америке, Восточной Азии, Юго-Восточной Азии со странами Персидского Залива - имплементируется ежегодно в рамках многолетних региональных или страновых программ Европейской комиссии по сотрудничеству, в которых описываются проекты и указываются выделяемые на них средства);

- применение Европейского инструмента по демократии и правам человека для финансирования миссий по наблюдению за выборами в третьих странах (187 млн. евро в 2016 г.);

- подготовка и реализация предложений по санкциям (служба представляет Комиссию при обсуждении санкционных вопросов с государствами-членами в рамках Рабочей группы советников по иностранным делам (RELEX Counsellors $\left.^{77}\right)$ и готовит проекты регламентов по санкциям, которые принимает затем Совет EC;

- обеспечение представительства Комиссии в «процессе Кимберли» ${ }^{78}$;

- работа по предотвращению торговли товарами, которые могли бы быть использованы для проведения смертной казни или для пыток (Служба готовит делегированные акты Комиссии - например, по спискам таких товаров) ${ }^{79}$.

${ }_{77}^{76}$ В 2014 г. они составили 733 млн. евро. См.: http://ec.europa.eu/dgs/fpi/about/index_en.htm.

77 Группа отвечает за рассмотрение всех горизонтальных аспектов подготовки и имплементации решений Совета. В особенности тех, что касаются институциональных, правовых, материально-технических и финансовых сторон обеспечения ОВПБ.

78 Кимберлийский процесс - организация, созданная в 2003 г. по инициативе международной алмазной индустрии и гражданского сообщества, чтобы перекрыть поток «конфликтных» бриллиантов, а именно алмазного сырья, используемого повстанческими движениями для финансирования своих военных действий, включая попытки подорвать или свергнуть законные правительства. Она насчитывает 54 участника, включая Европейский Союз, всего из 80 стран. Подробнее см.: www.kimberleyprocess.com.

79 Служба исполняет регламент Совета (Council Regulation (EC) No 1236/2005), касающийся торговли соответствующими товарами. Список запрещённых и контролируемых товаров содержится в регламенте Комиссии по имплементации этого решения (Commission Implementing Regulation (EU) No 775/2014). ВнастоящеевремяЕвропейскийпарламентиСоветрассматриваютпредложениеКомиссииповнесениюизмененийвр егламентСовета 2005 г. См.: Proposal for a REGULATION OF THE EUROPEAN PARLIAMENT AND OF THE 
В области торговой политики, где Комиссия ответственна за выработку мандата на ведение международных торговых переговоров и за ведение самих переговоров (конечно, такие мандаты, как и сами торговые соглашения, подлежат одобрению в Совете и ЕП), укреплению её позиций способствовала передача в сферу исключительной компетенции Союза некоторых вопросов ${ }^{80}$ (ранее они относились к смешанной компетенции Союза и государств-членов).Сохранилась координирующая роль ЕК по внешним аспектам внутренних политик (экология, транспорт, юстиция и правосудие), а также в отношении политики соседства, где ЕК отвечает за соответствующие программы. Уточним, что ОВПБ составляет лишь малую долю «широкой» внешней политики ЕС, которая к тому же всё больше пересекается с вопросами защиты прав человека, помощи развитию и гуманитарной помощи, в которых Комиссия тоже сохраняет свой контроль.

\section{ЕВРОПЕЙСКИЙ ПАРЛАМЕНТ}

Европейский парламент не формирует правительство европейского уровня. Такого правительства, по сути, нет, а исполнительную власть на европейском уровне в ЕС в основном делят между собой Совет и Европейская комиссия. Но подавляющее большинство государств-членов Евросоюза являются как раз парламентскими демократиями. В условиях парламентской демократии большинство, определяющее политической лицо (нижней или единственной) палаты, обычно солидаризируется с правительственной линией в международных делах и воздерживается от автономных внешнеполитических действий. Именно в международных отношениях такая поддержка собственного правительства более явно выражена, поскольку во внутренних делах парламентарии склонны защищать особые интересы избирателей собственного округа. Но так как у Европейского парламента нет «собственного» правительства, это даёт ему большую свободу в определении своих внешнеполитических позиций в отсутствие политической необходимости поддерживать позицию Совета, Верховного представителя по иностранным делам или Комиссии, которые, в совокупности, составляют исполнительную власть ЕС в том, что касается его внешней политики. Таким образом, у ЕП возникает существенная политическая автономия, определённый потенциал для развития собственной внешнеполитической идентичности ${ }^{81}$.

Лиссабонский договор укрепил законодательные полномочия Европарламента и его позиции во внешней политике ЕС, тогда как сам ЕП своей активностью на практике добился даже большего внешнеполитического влияния, чем предполагалось по договору ${ }^{82}$. Ранее у него не было формальной роли при ведении от лица ЕС переговоров по международным соглашениям. Теперь ЕП, если следовать букве договора, необходимо «незамедлительно и в полной мере» информировать о ходе таких переговоров «на всех этапах процедуры» (статья 218(10) ДФЕС). Формально Верховный представитель по иностранным делам обязан консультироваться с ним в отношении главных аспектов и основополагающих приоритетов Общей внешней политики и политики безопасности, а также информировать ЕП о развитии ОВПБ, надлежащим образом принимая взгляды ЕП во внимание. ЕП может также обращаться с вопросами (последние, однако, не обязаны отвечать на них) или

COUNCIL amending Council Regulation (EC) No 1236/2005 concerning trade in certain goods which could be used for capital punishment, torture or other cruel, inhuman or degrading treatment or punishment. Brussels, 14.1.2014 COM (2014) $\quad 1 \quad$ final. http://eur-lex.europa.eu/resource.html?uri=cellar:a9b0d53e-7e18-11e3-b88901aa75ed71a1.0002.05/DOC_1\&format=PDF.

80 Это касается сферы услуг, торговых аспектов прав интеллектуальной собственности и прямых иностранных инвестиций.

${ }^{81}$ Thym Daniel. The Intergovernmental Constitution of the EU's Foreign, Security \& Defence Executive // European Constitutional Law Review. 2011. Volume 7, Issue 3, pp. 453-480.

${ }^{82}$ Wisniewski Elisabeth. The Influence of the European Parliament on the European External Action Service // European Foreign Affairs Review. 2013. Vol. 18. № 1.P. 81-101. 
формулировать рекомендации в адрес Совета и Верховного представителя. Дважды в год в ЕП проводятся парламентские дебаты по внешнеполитическим вопросам. Но на деле Парламенту чаще всего приходится полагаться на добрую волю Совета в вопросе получения своевременной и значимой информации. Таким образом, здесь мы усматриваем наличие двойного демократического дефицита, так как вовлечение национальных парламентов в надзор за национальной внешней политикой тоже оставляет желать большего.

ЕП претендует на то, чтобы влиять на содержание международных соглашений, которые заключает Евросоюз. Инструментом для этого служат парламентские резолюции, в которых сформулированы позиции ЕП, излагаются условия, на которых евродепутаты готовы дать своё согласие. Чаще всего такие условия предполагают политическую кондициональность. Торговая политика для Европарламента, в частности, явно не выглядит самоцелью. Они видит в ней скорее средство по продвижению внешнеполитических целей Евросоюза, включая распространение в мире европейских норм. По мнению ЕП, ЕС должен укреплять свои экономические отношения с другими регионами мира на основе мира и принципов суверенитета, уважения гражданских свобод и сохранения окружающей среды, поддержания социальных стандартов, прав человека и целей развития» ${ }^{83}$.

Формально ЕП не имеет касательства к заключению Евросоюзом соглашений в рамках ОВПБ. Но при заключении широкого круга иных международных соглашений (об ассоциации третьих стран с ЕС, о присоединении ЕС к Европейской конвенции по правам человека, соглашений, предполагающих использование средств из бюджета ЕС и др.), включая те, где затрагиваются вопросы, по которым внутри ЕС действует обычная законодательная процедура ${ }^{84}$, от ЕП требуется согласие (consent). Широко применяемая практика трёхсторонних переговоров по европейским правовым актам (trialogues) с участием Комиссии, Совета и государств-членов сделали ЕП важным посредником в соответствующих вопросах.

Значительная часть работы Парламента по ОВПБ осуществляется в специализированных комитетах, в особенности в комитете по иностранным делам (AFET) и двух его подкомитетах - по безопасности и обороне $(S E D E)$ и по правам человека $(D R O I)$, а также в комитете по международной торговле (INTA) и в комитете по развитию (DEVE). Это главные связующие звенья между ЕП и структурами глобального управления (включая $\mathrm{OOH})$, другими институтами ЕС, страной-председательницей в Совете и национальными парламентами государств-членов.

Комитет по иностранным делам включает 76 полных членов и является крупнейшим комитетом Европарламента. Несколько рабочих групп помогают ему определить позицию по определённым вопросам внешней политики (например, рабочие группы по отношениям с ООН, со странами Западных Балкан, по Восточному партнёрству, по конфликтам, безопасности и развитию, а также по различным финансовым инструментам, которые задействованы в области внешней политики ЕС). Комитет по иностранным делам редко занимается законодательной работой - за исключением подготовки парламентского согласия (consent) по международным соглашениям, а также участия в обычной законодательной процедуре один раз каждые пять-семь лет при принятии решений по внешнеполитическим финансовым инструментам. Существенная часть работы этого комитета состоит в контроле или мониторинге действий Комиссии, Совета, Верховного представителя и ЕСВД. Группа европарламентариев, представляющих крупные фракции Европарламента, включая глав

83 European Parliament resolution of 22 May 2007 on Global Europe - external aspects of competitiveness $(\underline{2006 / 2292(I N I))}$ $0196+0+\mathrm{DOC}+\mathrm{XML}+\mathrm{V} 0 / / \mathrm{EN}$.

${ }^{84}$ Обычная законодательная процедура распространяется на большинство аспектов внутренней политики ЕС включая сельское хозяйство, рыболовство и правосудие. 
$A F E T$ и $S E D E$, имеют право доступа к конфиденциальной внешнеполитической информации, проходящей по линии Совета.

В 2008 г. Европарламент по собственной инициативе создал Офис по продвижению парламентской демократии в мире, который заработал на следующий год ${ }^{85}$. Это важный инструмент его работы по линии парламентской дипломатии. Офис по продвижению демократии (в странах соседства и в развивающихся странах) входит в директорат по поддержке дипломатии Генерального директората ЕП по внешней политике. Этот директорат включает также Секцию по наблюдению за выборами и Секцию по правам человека. Группа по поддержке демократии и координации действий по наблюдениям за выборами в составе 15 человек осуществляет политическое руководство Офисом. Председателями группы являются главы комитета по иностранным делам и комитета по развитию $^{86}$. Он поддерживает контакты с Панафриканским парламентом (ПАП - парламент Африканского союза), парламентами ЭКОВАС (Экономическое сообщество западноафриканских государств), САДС (Сообщество развития Юга Африки), ВАС (Восточноафриканское сообщество), а также с региональными парламентами в Латинской Америке.

Парламент организует публичные дебаты (проходящие на пленарном уровне и на уровне комитетов), включая слушания и семинары, принимает резолюции и готовит доклады по собственной инициативе, учреждает специальные комиссии по расследованию, подтверждает назначения на различные посты. Все эти возможности активно используются и применительно к сфере внешней политики ЕС.

Укажем, что переходное соглашение между Евросоюзом и США об условиях доступа американцев к данным международной системы межбанковских платежей SWIFT при проведении антитеррористических расследований, подписанное в конце 2009 г., было отвергнуто ЕП как предоставляющее США неоправданные преимущества и противоречащее базовым ценностям европейского интеграционного объединения ${ }^{87}$.

ЕП должен одобрить многолетние финансовые рамки, включая папку по европейским внешним действиям, для вступления их в силу, он принимает (вместе с Советом) ежегодный бюджет ЕС и контролирует расходы интеграционных институтов. ЕП имеет бюджетные полномочия в отношении гражданских миссий по линии ОВПБ и ОПБО (военные операции не финансируются из общего бюджета), которые он иногда использует, чтобы повлиять на содержание определённых решений. Однако полный парламентский контроль в этом смысле отсутствует. С ЕП формально не советуются при принятии конкретных решений по линии ОВПБ, которые имеют бюджетные последствия.

Всего можно насчитать свыше 100 политических органов, имеющих дело с различными аспектами парламентской внешней политики ЕC, распространяющейся на 190 стран мира ${ }^{88}$.

В их числе следующие межпарламентские делегации:

\footnotetext{
${ }^{85}$ The Office for Promotion of Parliamentary Democracy - An Overview of its first 2 years work (2008-2009) http://www.europarl.europa.eu/meetdocs/2009_2014/documents/deve/dv/oppd_overview_2008_20/oppd_overview_200 8 2009.pdf.

${ }^{86}$ Подробнее о деятельности Офиса см.: OPPD Newsletter - Volume 4 - June 2012. http://www.agoraparl.org/sites/default/files/office_for_promotion_of_parliamentary_democracy_newsletter_-_volume_4_-

june_2012.pdf.

${ }^{87}$ Monar Jörg. The Rejection of the EU-US SWIFT Interim Agreement by the European Parliament: A Historic Vote and Its Implications // European Foreign Affairs Review. 2010. Vol. 15. P. 143-151.

${ }^{88}$ Baltay Peter. Shaping and Controlling Foreign Policy. Parliamentary Diplomacy and Oversight, and the Role of the European Parliament. July 2015. http://www.europarl.europa.eu/RegData/etudes/STUD/2015/549045/EXPO_STU(2015)549045_EN.pdf.
} 
- Совместная парламентская ассамблея АКТ-ЕС. Она включает по 78 депутатов ЕП и национальных парламентов стран Африки, Карибского моря и Тихого океана (подписавших Соглашение Котону 2000 г.);

- ЕвроЛат (EuroLat), совместная многосторонняя ассамблея, куда входят по 75 депутатов от ЕП и латиноамериканских региональных парламентов (Парлатино Латиноамериканский парламент), Парландино (Андский парламент), Парласен (Центральноамериканский парламент), Парласур (парламент группировки Меркосур), а также национальные конгресс Чили и Мексики;

- Парламентская ассамблея ЕвроНест $(\text { EuroNest })^{89}$ - парламентский форум Восточного партнёрства, который имеет четыре постоянных тематических комитета (по вопросам политики, экономики, энергетики и социальной политики), две рабочие группы (по Беларуси и по правилам процедуры) и проводит ежегодные пленарные заседания - в него входят по 60 депутатов ЕП и парламентариев из стран Восточного партнёрства ${ }^{90}$;

- Парламентская ассамблея Средиземноморского союза (120 парламентских представителей из 10 средиземноморских стран. 75 парламентариев из стран ЕС и 45 евродепутатов).

В 2002 г. по инициативе Межпарламентского союза ${ }^{91}$ и ЕП была организована Парламентская конференция Всемирной торговой организации ${ }^{92}$, которая с тех пор собирается ежегодно.

С 2012 г. Европейский парламент и национальные парламенты государств-членов ежегодно организуют две межпарламентские конференции по вопросам внешней политики и политики безопасности (такое межпарламентское сотрудничество предусмотрено Протоколом к Лиссабонскому договору о роли национальных парламентов в Европейском союзе).

\section{СУД ЕС}

Зафиксировав отказ от прежней системы трёх опор, Лиссабонский договор не устранил традиционную дихотомию между Общей внешней политикой и политикой безопасности, включая Общую политику безопасности и обороны, и его прочими внешними компетенциями, которые ранее относились к внешним сношениям Европейского сообщества. Тем не менее, формулировки касательно юрисдикции Суда ЕС в отношении ОВПБ были изменены ${ }^{93}$.

Во-первых, Суд ЕС, хотя и в ограниченных рамках, получил возможность судебного контроля в отношении определённых актов, которые принимаются по линии ОВПБ, т.е. с полным иммунитетом данной политики в вопросе судебного надзора теперь покончено. В частности, Суд ЕС уполномочен контролировать правомерность рестриктивных ограничений, которые действуют в отношении физических и юридических лиц. В статье 24(1) ДЕС говорится, что Суд ЕС вправе контролировать правомерность некоторых решений, указанных во втором абзаце статьи 275 ДФЕС, где, в свою очередь, сказано, что Суд правомочен выносить решения по искам, подаваемым на условиях, предусмотренных в

\footnotetext{
${ }^{89}$ The EU-Neighborhood East Parliamentary Assembly.

9010 мест, выделенных Беларуси, пока остаются вакантными. Белорусские власти отвергли формулу состава делегации, которая включала бы пять членов палаты представителей и пять оппозиционных политиков.

${ }^{91}$ Межпарламентский союз (ㅅг․ Inter-Parliamentary Union, $\phi p$. L'Unio nInterparlementaire) - созданная в

1889 г. международная организация, которая осуществляет координацию действий парламентов мира, см.: http://www.ipu.org/english/home.htm.

92 The Parliamentary Conference of the World Trade Organization, cm.: https://www.wto.org/english/forums_e/parliamentarians_e/parliamentarians_conf_e.htm.

${ }^{93}$ Hillion Ch. A Powerless Court? The European Court of Justice and the EU Common Foreign and Security Policy. January 30, 2014. [Electronic resource]. Mode of access:http://ssrn.com/abstract=2388165 or http://dx.doi.org/10.2139/ssrn.2388165.
} 
четвёртом абзаце статьи 263 ДФЕС 94 . Суд действует в таких случаях в целях контроля правомерности решений, принимаемых Советом, которыми предусматриваются ограничительные меры против физических или юридических лиц. Наделение Суда такими возможностями является дополнением к той юрисдикции, которой он и ранее обладал в отношении актов Европейского сообщества, имплементирующих меры, принимаемые по линии ОВПБ. Таким образом, теперь физических и юридические лица способны оспорить законность любых рестриктивных мер ЕС, которые принимаются в рамках ОВПБ ${ }^{95}$.

Во-вторых, была перенастроена роль Суда ЕС в обеспечении сохранения границы между внешними компетенциями ЕС, которые основаны на Договоре о функционировании ЕС (бывшие внешние сношения) и на договорных положениях, относящихся к ОВПБ. Суд ЕС может иметь право голоса в отношении заключаемых ЕС международных соглашений, содержащих аспекты, относящиеся к ОВПБ. В частности, если такое соглашение было одобрено в нарушение процедурных требований по статье 218 ДФЕС, то его принятие может быть оспорено в Суде ЕС Европейским парламентом. ЕП может также оспорить утверждение Совета, что данное соглашение относится исключительно к сфере ОВПБ.

В-третьих, способность Суда ЕС обеспечивать соблюдение принципов, составляющих фундамент правового порядка Евросоюза, получила более широкую трактовку, нежели раньше. В итоге он далеко не столь бессилен в данной области, как могло бы показаться на поверхностный взгляд. Ведь именно он стоит на страже конституционных норм (демократия, верховенство права, уважение фундаментальных прав), а также принципов, закреплённые в первичном праве ЕС (прежде всего, в основополагающих договорах: например, принципы добросовестного сотрудничества ${ }^{96}$ и единого подхода ${ }^{97}$ ).

\footnotetext{
94 Любое физическое или юридическое лицо может подавать иски против актов, адресатом которых оно является либо которые непосредственно и индивидуально его затрагивают, а также против регламентарных актов, которые непосредственно его затрагивают и не требуют исполнительных мер.

${ }^{95}$ Eckes Christina. EU Counter-Terrorist Sanctions against Individuals: Problems and Perils // European Foreign Affairs Review. 2012. Vol. 17. № 1. Р. 113-132.

${ }^{96}$ Sincere cooperation - принцип, вытекающий из статьи 4 ДЕС - в контексте отношений между Евросоюзом и государствами-членами и статьи 13 ДЕС - в контексте отношений между институтами ЕС. Он означает, что государства-члены должны предпринимать все необходимые меры, чтобы выполнять свои договорные обязательства, и не делать ничего, что причинило бы ущерб должному функционированию Европейского союза.

${ }^{97}$ Consistency principle - данный принцип проявляет себя как в горизонтальном (сотрудничество между институциональными акторами, вовлечёнными в процесс принятия решений в ЕС), так и в вертикальном (ясное разграничение компетенции и предотвращение конфликтов между правовыми порядками ЕС и государствчленов) срезах европейского управления.
} 


\section{§ 2.2 ЕВРОПЕЙСКАЯ СЛУЖБА ВНЕШНЕПОЛИТИЧЕСКИХ ДЕЙСТВИЙ}

По данным 2013 года, в Европейской службе внешнеполитических действий работало 3400 человек, из них около 1450 - в Брюсселе и 1950 - в зарубежных миссиях. Из этой общей цифры в 900 человек были чиновниками высокого ранга. 600 из них пришли в Службу из Комиссии или из Секретариата Совета. Оставшиеся 300 были командированы национальными дипломатическими службами на ограниченное время (так называемые временные агенты). Для сравнения: в том же 2013 г. в национальных дипломатических службах 27 государств-членов трудились совокупно 85000 человек. Таким образом, на долю ЕСВД приходится примерно 4\% от общего числа профессионалов Евросоюза в вопросах внешней политики ${ }^{98}$.

До создания Европейской службы внешнеполитических действий собственную «внешнюю политику» ЕС вели как Европейский совет/Совет, так и Комиссия (с 1958 г. действовал Генеральный директорат ЕК по вопросам внешних сношений, который в 2011 г. был расформирован, но фактически вошел в структуру ЕСВД). Такая двойственность служила причиной институциональных противоречий и негативно сказывалась на способности ЕС выработать консолидированную и последовательную позицию по внешнеполитическим вопросам. Но активная работа по созданию специальной структуры, которая объединила бы хаотичные усилия разных служб и подразделений по проведению внешней политики Евросоюза, велась с начала XXI века. Подтверждением этому служит проект Договора, учреждающего Конституцию для Европы (так и не вступившего в силу), который предусматривал создание должности министра иностранных дел и одновременно создавал министерство иностранных дел. Этот договор был подписан главами государств 29 октября 2004 г., но его не ратифицировали - из-за провала на национальных референдумах в Нидерландах и во Франции в мае-июне 2005 г. В дальнейшем пост министра иностранных дел был заменен на (менее амбициозный по наименованию и по содержанию) пост Верховного представителя ЕС по иностранным делам и политике безопасности, а вместо Договора о конституции в Лиссабоне был принят Договор о реформе (его более скромная версия), т.е. Лиссабонский договор.

Официально Европейская служба внешних связей начала функционировать с 1 января 2011 г. $^{99}$. Во главе службы стоит Верховный представитель ЕС по иностранным делам и политике безопасности, который/которая одновременно является заместителем председателя Европейской комиссии и постоянным председателем Совета ЕС в формате министров иностранных дел (Совет министров иностранных дел), а также формальным главой Европейского оборонного агентства (EOA), (на практике непосредственное управление осуществляет Главный администратор ЕОА).

Первым Верховным представителем по иностранным делам в формате, определённом Лиссабонским договором ${ }^{100}$, в ноябре 2009 г. стала британка Кэтрин Эштон (Catherine Ashton)- до этого она в течение года была членом Европейской комиссии по торговле, где достаточно хорошо себя зарекомендовала. Впрочем, её назначение на новый пост явилось довольно неожиданным. Она оказалась консенсусной фигурой, приемлемой, в первую

\footnotetext{
${ }^{98}$ Ashton C. EEAS Review. European External Action Service. Brussels, 2013. 23 p.; Balfour R., Raik K. The EEAS and national diplomacies // European Policy Centre Paper. 2013. № 73.

99 В качестве даты создания ЕСВД в литературе можно также встретить 1 декабря 2010 г. Но формально Служба начала свою работу именно 1 января 2011 г., поскольку месяц ушел на переезд чиновников из других подразделений в штаб-квартиру ЕСВД.

${ }^{100} \mathrm{~B}$ прежнем виде пост Высокого представителя по внешней политике и политике безопасности, с более скромными полномочиями, был введён в 1999 г. на основании Амстердамского договора (его в течение 10 лет занимал испанец Хавьер Солана, до этого - Генеральный секретарь НАТО).
} 
очередь, для европейских социалистов и социал-демократов. Британский премьер-министр Гордон Браун выдвинул кандидатуру Эштон на пост Верховного представителя после того, как стало ясно, что кандидатура на пост председателя Европейского совета бывшего британского премьера Тони Блэра, чья репутация в Европе пострадала из-за принятого им решения об участии Великобритании в военной кампании НАТО в Ираке, не получит достаточной поддержки в Брюсселе и основных европейских столицах. В 2014 г. Могерини сменила Эштон в роли Верховного представителя ЕС по иностранным делам.

Верховный представитель назначается Европейским советом, который действует при этом квалифицированным большинством, при согласии главы Комиссии. Но чтобы взять на себя роль в Комиссии в качестве заместителя её председателя, будущий Верховный представитель должен/должна также явиться в ЕП, чтобы ответить на вопросы, и затем его/её кандидатура подлежит одобрению со стороны Европарламента (в полном составе новой Комиссии).

В число обязанностей Верховного представителя Союза по иностранным делам и политике безопасности входит следующее:

(1) ведение внешнеполитического курса EC;

(2) координация работы тематических инструментов реализации внешней политике ЕC;

(3) участие в выработке общего курса во внешней политике стран;

(4) регулярное присутствие на встречах глав государств и правительств стран ЕС в составе Европейского совета;

(5) обеспечение последовательности внешних действий Евросоюза, которые предпринимаются по разным направлениям;

(6) представительство ЕС в вопросах, относящихся к общей внешней политике и политике безопасности, ведение политического диалога с третьими сторонами от лица Евросоюза, выступления с изложением позиций ЕС в международных организациях и на международных конференциях;

(7) руководство ЕСВД и делегациями Евросоюза в третьих странах и международных организациях;

(8) управление работой Европейского оборонного агентства и Института ЕС по изучению вопросов безопасности.

Компетенции Верховного представителя столь же многообразны, как и его/её структурные связи с различными институтами и органами. В качестве члена Комиссии, она должна подчиняться внутренним правилам работы ЕК и следовать коммунитарному (наднациональному) методу ведения дел. В вопросах «высокой» внешней политики она должна вписаться в межправительственный метод.

В трактовке Амстердамского договора Высокий представитель по иностранным делам был связан только с Советом. Это был чистой воды межправительственный актор, который занимался исключительно внешней (в узком смысле) и оборонной политикой. Те сферы внешних сношений, которые были включены в первую опору, оставались прерогативой Комиссии.

От главы внешнеполитической службы Евросоюза ждут исполнения четырёх ролей, которые, по большей части, лежат в разных плоскостях:

(1) роли лидера в проведении внешней политики вместе с государствами - членами $\mathrm{EC}$, но без ущемления их интересов, что позволяло бы продвигать общую политику обороны (это напрямую указывается в Договоре о ЕС - ст. 18(2), ст. 22(2), ст. 27(1), ст. 30(1));

(2) роли посредника между странами ЕС в случае конфликта интересов, который будет способствовать налаживанию диалога, поиску взаимопонимания и компромиссов именно для этого Верховный представитель выступает постоянным председателем Совета ЕС по иностранным делам; 
(3) роли гаранта стабильности внешнеполитического курса ЕC, что требует от неё быть достаточно хорошим управленцем, чтобы обеспечить слаженные действия всех институтов ЕС и их подразделений, имеющих компетенции на международной арене;

(4) роли дипломата и лица, представляющего ЕС во внешнем мире.

Итоги пребывания К. Эштон на посту Верховного представителя ЕС по иностранным делам получили довольно скромную оценку: она, по общему мнению, лучше справилась с ролью дипломата и управленца, но ей не удалось проявить себя как яркого лидера. От неё исходило слишком мало инициатив. Ей не удалось создать согласованный тандем с председателем Европейского совета Херманом Ван Ромпёем.

У нового Верховного представителя Федерики Могерини тоже не хватает двух наиболее существенных черт, которые, по всей видимости, нужны были бы более эффективному представителю внешней политики ЕС: это опыт руководящей работы в интегрированной Европе и персональный международный статус. Она не работала ранее в системе ЕС, т.е. не может пока знать досконально его сложную институциональную систему. У неё нет и непосредственного предшествующего опыта участия в выстраивании замысловатой бюрократии ЕСВД. Её срок работы в Совете тоже минимальный - в конце концов, до нынешнего назначения она лишь полгода провела на посту итальянского министра иностранных дел, и за пределами Европы её знали мало.

Генеральным секретарём Службы с 1 сентября 2016 г. назначена немецкий дипломат Хельга Мария Шмид (Helga Maria Schmid). Её назначение, как следует из комментариев наблюдателей, могло последовать после неожиданной отставки предыдущего Генерального секретаря Алена Леруа (Alain Le Roy), который, хлопнув дверью, выразил тем своё недовольство сокращением масштаба своих действий по формированию политики на этом посту по сравнению с обязанностями Пьера Вимона (Pierre Vimont), занимавшего его при Эштон ${ }^{101}$.

Генеральный секретарь осуществляет надзор за ежедневной работой в штаб-квартире ЕСВД. Заместители Генерального секретаря курируют основные направления работы Службы, в том числе пять крупных департаментов по географическому признаку: по Азиатско-Тихоокеанскому региону, по Африке, по Европе и Центральной Азии (в его составе Россия отнесена к подразделению, которое занимается также странами Восточного партнёрства, Центральной Азией, региональным сотрудничеством и Организацией по безопасности и сотрудничеству в Европе), по Большому Ближнему Востоку и по Америк (см. далее Схему 2-2).

К ним примыкает департамент по правам человека, по глобальным и многосторонним вопросам (включая координацию усилий ЕС в сфере международного развития, а также продвижение демократии) (см. далее Схему 2-3). Отдельный блок образуют органы, действующие в сфере политики безопасности и обороны, а также кризисного урегулирования (см. далее Схему 2-4).

Лиссабонский договор трансформировал систему представительств ЕК в делегации Евросоюза, наделив их более широкими (политическими) функциями. Делегации ЕС действуют в тесном сотрудничестве с дипломатическими и консульскими миссиями государств-членов. В ежедневной работе они подчёркивают свою дополнительную полезность относительно усилий национальных дипломатических служб. Но вместе с тем делегации ЕС становятся значимыми дипломатическими акторами, у которых больше веса и которые заметнее в стране пребывания, чем большинство национальных посольств. Они призваны выполнять три задачи:

- представлять Евросоюз в третьих странах по широкому кругу вопросов;

\footnotetext{
${ }^{101}$ Heath Ryan. Juncker in trouble - Brexit - EEAS' Le Roy resigns // Politico, 16.06.2016. [Electronic resource]. Mode of access: http://www.politico.eu/newsletter/playbook/politico-brussels-playbook-presented-by-qualcomm-juncker-introuble-brexit-eeas-le-roy-resigns/
} 
- координировать усилия государств-членов и помогать им;

- вносить свой вклад в выработку внешней политики ЕС в качестве неотъемлемой части ЕСВД.

После реформы по Лиссабонскому договору вся эта система вошла в состав Европейской службы внешнеполитической деятельности, а функции делегаций существенно расширились. Поскольку делегации обеспечивают прямую и постоянную связь между Европой и третьими странами, мы можем назвать их важным инструментом по обеспечению Евросоюзу общего голоса в мире. Мандаты делегаций ЕС и глав делегаций определены в решении Совета от 26 июля 2010 г. (ст. 5) ${ }^{102}$. Там указано, что делегации ЕС должны оказывать помощь институтам $\mathrm{EC}$, в частности, Европейскому парламенту, в их деятельности в третьих странах, а также поддерживать страны ЕС в их дипломатических отношениях и предоставлять консульскую защиту европейским гражданам в третьих странах. Делегации ответственны не только за внешнеполитические вопросы, но и за те вопросы внутренней политики ЕС, которые имеют международное измерение, но попрежнему отнесены к компетенции Комиссии. Члены делегаций, включая главу делегации и его заместителей, зачастую перегружены административной работой, что мешает

${ }^{102}$ Council Decision of 26 July 2010, establishing the organisation and functioning of the European External Action Service (2010/427/EU). URL: https://eeas.europa.eu/sites/eeas/files/eeas_decision_en.pdf. 


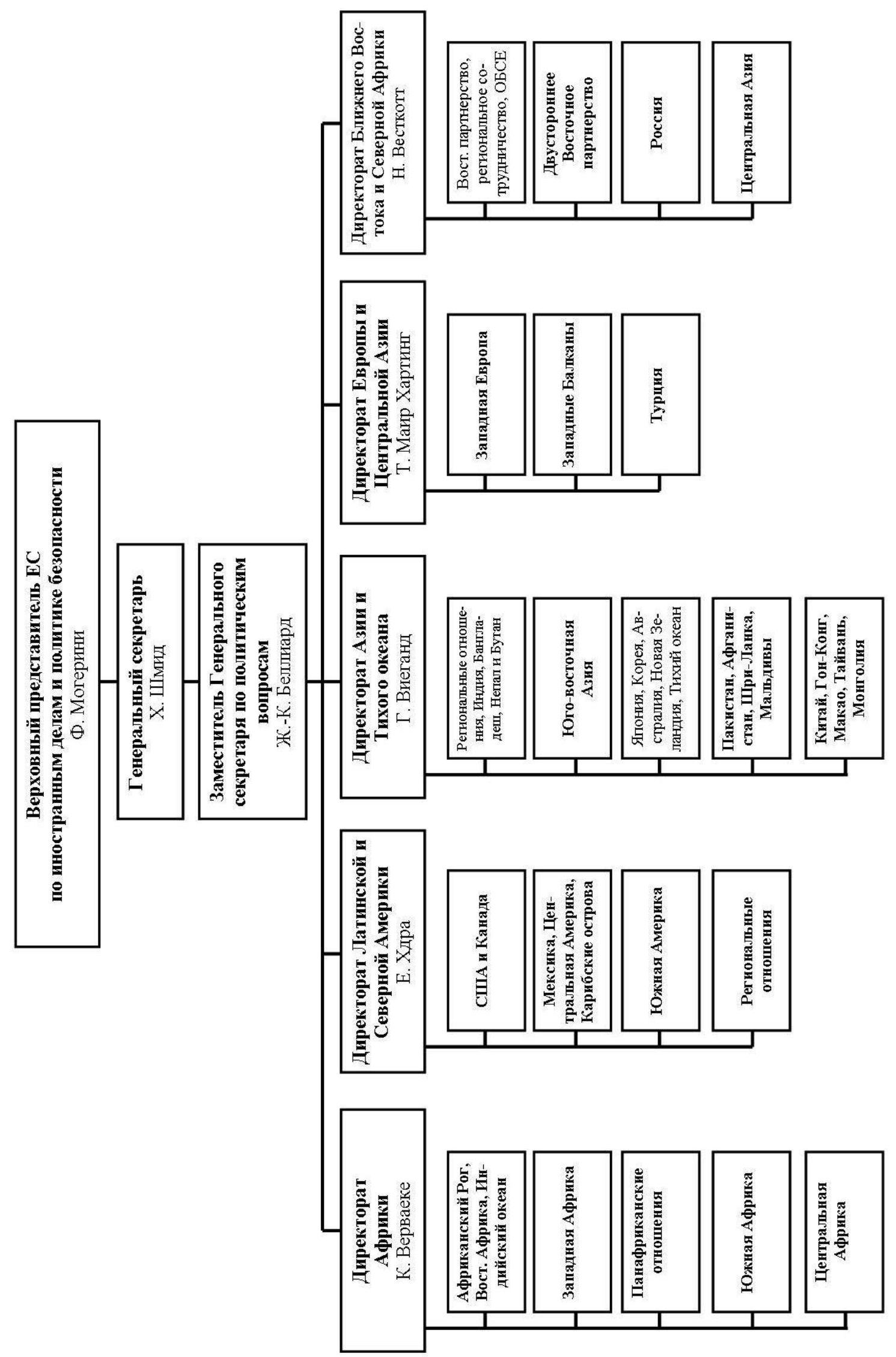

Схема 2-2. Географические департаменты ЕСВД 


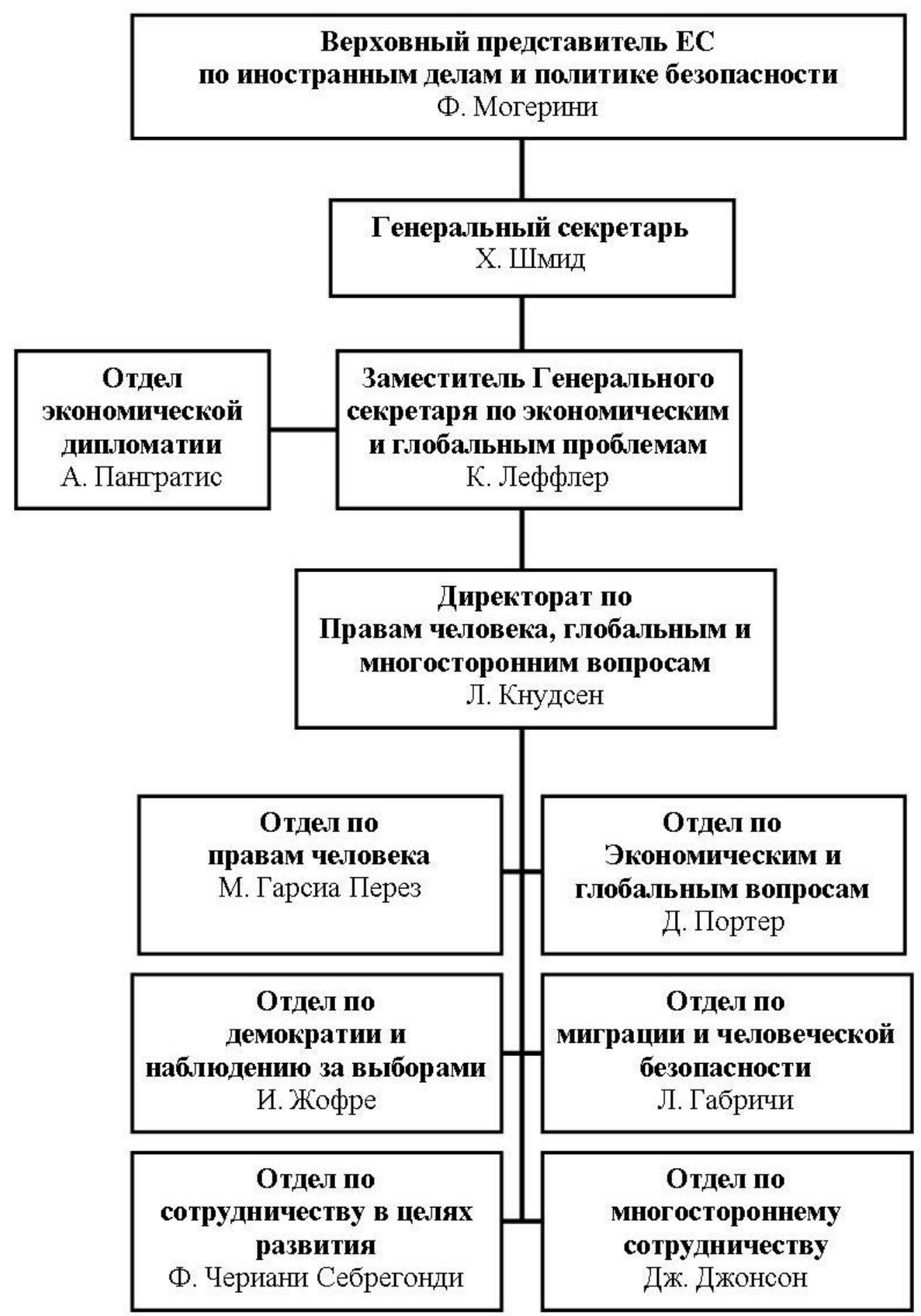

Схема 2-3. Отделы ЕСВД по экономическим и глобальным проблемам 


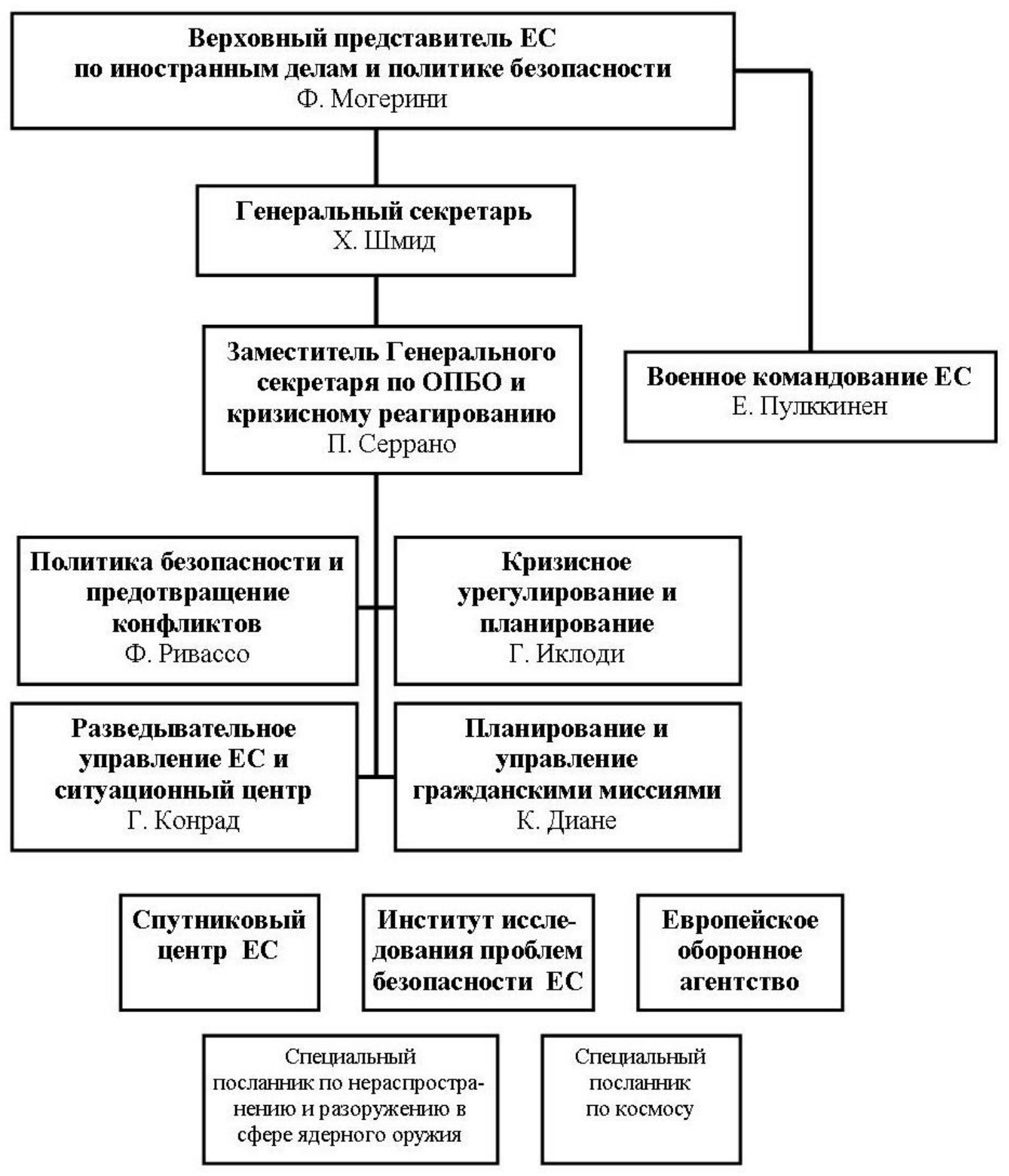

Схема 2-4. ЕСВД: Блок ОПБО и кризисного реагирования

сконцентрироваться на политической составляющей их деятельности. В административную работу входит также управление финансовыми программами, с чем часть даже опытных сотрудников миссий попросту не сталкивалась ранее (пришлось организовать специальные курсы и тренинги по финансовым вопросам для глав делегаций). Ещё одной сложной задачей стала выработка общей корпоративной культуры (esprit de corps). Абсолютное большинство глав делегаций ЕС - дипломаты из стран ЕС, ранее не работавшие в системе европейских институтов. Почти половину контингента сотрудников ЕСВД в делегациях 
составляют дипломаты государств-членов, направленные в ЕСВД в качестве «временных агентов» на период от 4 до 10 лет. Остальные - это бывшие сотрудники Комиссии, перешедшие в ЕСВД в декабре 2010 г. Есть также меньшая часть сотрудников, направленная на работу в делегации по инициативе самих стран ЕС - командированные национальные эксперты, чья работа оплачивается национальными правительствами.

Решение объединить в делегациях сотрудников Комиссии и ЕСВД выглядит, на первый взгляд, рискованным. Трения действительно возникают, но серьёзного раскола на наднациональную и межправительственную сферы работы делегаций не наблюдается.

Главы делегаций получают инструкции от Верховного представителя, которому они подчиняются. Комиссия также имеет право направить главам делегаций свои инструкции по вопросам, выходящим за рамки общей политики обороны и безопасности. При этом, для смягчения межинституциональных противоречий, которые все же имеют место, Комиссия направляет копию таких инструкций также Верховному представителю и в ЕСВД. Взаимодействие между делегациями и ЕСВД сводится к тому, что делегации регулярно отправляют в Брюссель аналитические отчеты о своей работе и о состоянии дел в стране пребывания.

Вопрос о демократической подотчётности ЕСВД остаётся по существу не решённым. Между тем в современных демократических обществах всё меньше доверия вызывает точка зрения, что внешняя политика и дипломатия несовместимы с демократическим и прозрачным процессом принятия решений ${ }^{103}$. Более того: для внешнеполитической службы, представляющей Евросоюз как организацию, которая стремится играть по сути менторскую роль в процессах строительства государства и демократической системы в различных странах по всему миру, обеспечение демократической подотчётности непременно должно стать важной заботой. Ведь разница между традиционными дипломатами и дипломатическими представителями ЕС в таких странах, как Босния-Герцеговина, очень существенна: последние непосредственно участвуют в управлении страной, имеют в этом смысле серьёзные полномочия и распоряжаются существенными бюджетами.

${ }^{103}$ Hill Christopher. The Changing Politics of Foreign Policy. London: Palgrave Macmillan, 2003. 416 p. 


\section{§ 2.3 СПЕЦИАЛЬНЫЕ ПРЕДСТАВИТЕЛИ}

Ocобое место в дипломатии ЕС занимают специальные представители (таковых сейчас насчитывается девять) ${ }^{104}$. Спецпредставители присутствуют в таких регионах и странах, как Центральная Азия, Ближний Восток, Афганистан, Босния и Герцеговина, Косово, Южный Кавказ и Грузия, Африканский Рог и в Сахеле. Кроме того, в 2012 г. учрежден пост специального представителя ЕС по правам человека. Есть также три специальных посланника: по нераспространению и разоружению в сфере ядерного оружия ${ }^{105}$, по космосу и по мирным переговорам в Колумбии ${ }^{106}$. Первые два были назначены в составе ЕСВД и работают в сфере ответственности Генерального секретаря Службы. Третий, будучи назначен в ноябре 2015 г., работает под прямым руководством Верховного представителя (специальные посланники менее тесно связаны с Советом, чем специальные представители). В 2016 г. председатель ЕК Юнкер назначил собственного посланника - для продвижения свободы вероисповедания или веры за пределами $\mathrm{EC}^{107}$.

Специальные представители ${ }^{108}$ призваны, прежде всего, оказывать содействие Верховному представителю ЕС по иностранным делам в деятельности по урегулированию международных конфликтов в проблемных странах и регионах. Первый специальный посланник- Альдо Айело (Aldo Ajello) был назначен в регион Великих Африканских озёр (в марте 1996 г.), после чего последовало назначение еще одного спецпредставителя ЕС - по ближневосточному мирному урегулированию (в ноябре 1996 г.) ${ }^{109}$. В это время у Европейской комиссии в Африке уже был много постоянных представительств, но они занимались помощью развитию, торговлей и строительством институтов, и государствачлены не считали их важными действующими лицами в сфере «высокой» политики и безопасности, к которой относится урегулирование конфликтов.

Появление такой должности в 1990-е годы отражало уже длительную на тот момент вовлеченность ЕС в процессы урегулирования конфликтов в странах Центральной Африки и на Ближнем Востоке, но главная задача спецпредставителей сначала сводилась только к сбору данных о ситуации в зоне конфликта с тем, чтобы в дальнейшем ЕС, на основе полученных сведений, мог с большей уверенностью выстраивать свой курс в отношении определенной страны или региона.

Страны назначения спецпредставителей распадаются на три группы: (1) страны Западных Балкан, являющиеся кандидатами на вступление в EC; (1) страны, участвующие в Европейской политике соседства (ЕПС); страны, не входящие в ЕПС, на которые, тем не менее, распространяются стратегические интересы ЕС. Отметим, что не все спецпредставители физически находятся в регионах своего назначения - большая часть из них постоянно работает в Брюсселе, периодически посещая страны своего мандата.

\footnotetext{
${ }^{104} \mathrm{http}: / /$ eeas.europa.eu/headquarters/headquarters-homepage/3606/eu-special-representatives_en.

$105 \mathrm{http}: / /$ www.eeas.europa.eu/non-proliferation-and-disarmament/special_envoy/index_en.htm

${ }^{106}$ EU Special Envoy for The Peace Process In Colombia. http://www.gilmore.ie/euenvoy/

${ }^{107}$ European Commission Press Release. President Juncker appoints the first Special Envoy for the promotion of freedom of religion or belief outside the European Union. Vatican City, 6 May 2016. [Electronic resource]. Mode of access: http://europa.eu/rapid/press-release_IP-16-1670_en.htm.

${ }^{108}$ Fouéré E. The EU Special Representatives: A dwindling but resilient resource at the service of EU Foreign and Security Policy // CEPS Policy Brief. 2016. № 348. 12 p.

${ }^{109}$ Whitman R.G., Wolff S. The European Union as a Global Conflict Manager. London: Routledge, 2012. P. 156.
} 


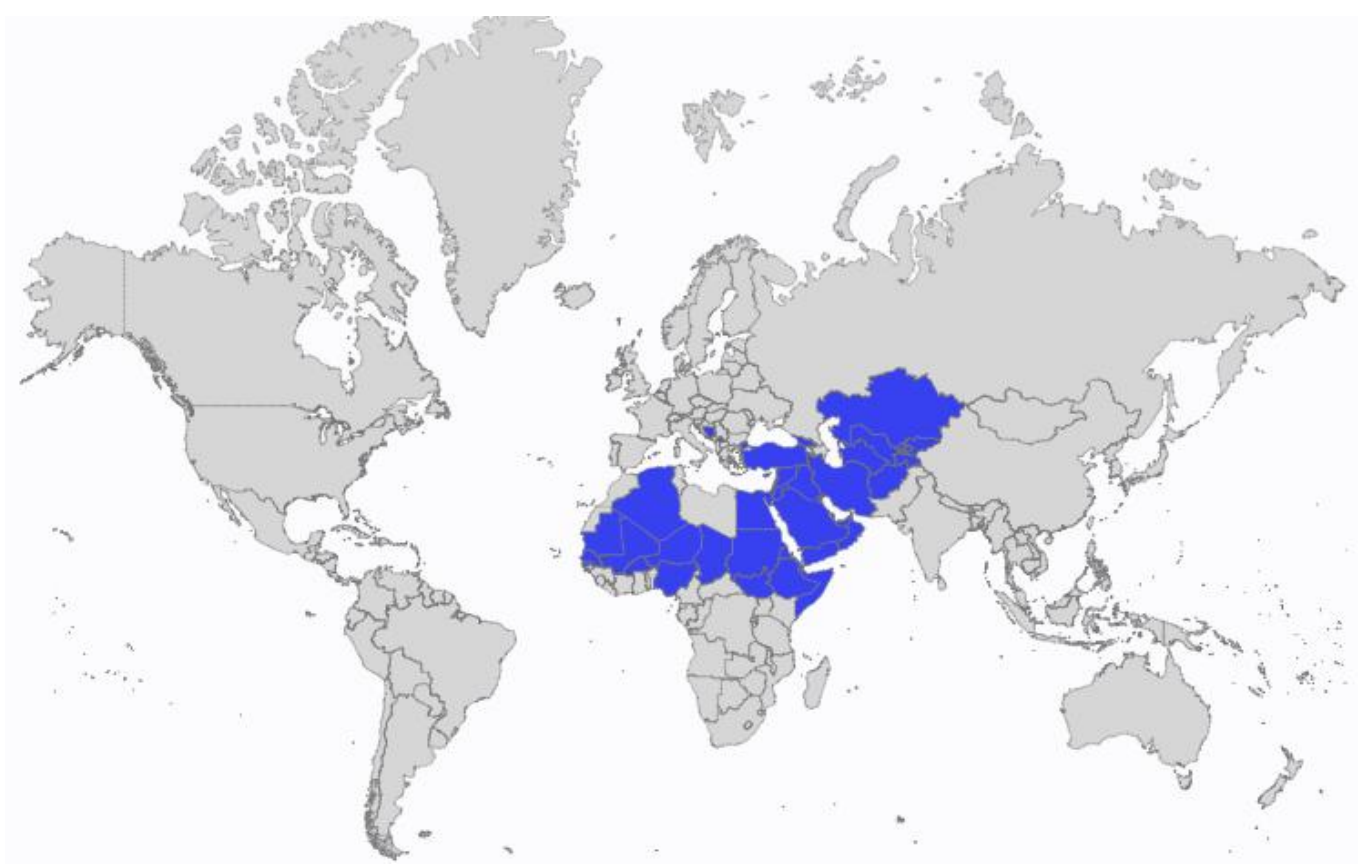

Рисунок 2-1. Страны мира, на которые распространяются мандаты специальных представителей ЕС географического профиля

Специальные представители не являются частью формальной иерархии ЕСВД. Фактически это инструмент Совета, который работает под стратегическим руководством Комитета по политике и безопасности (КПБ), входящего в его структуру. Процесс назначения специальных представителей закреплен в ст. 33 ДЕС, где говорится: «Совет по предложению Верховного представителя Союза по иностранным делам и политике безопасности может назначать специального представителя, которого он наделяет мандатом в отношении отдельных политических вопросов. Специальный представитель осуществляет свой мандат под руководством Верховного представителя». Выбор конкретного лица на пост спецпредставителя - это всегда результат компромисса и согласования позиций странучастниц по разным кандидатурам. Однако формальное предложение об их назначении, как мы видим, в компетенции Верховного представителя.

Пост спецпредставителя занимают, как правило, дипломаты высокого ранга из стран Союза, работавшие ранее либо в международных организациях, либо в институтах ЕС, либо в национальных министерствах иностранных дел. Три спецпредставители (в Афганистане, Боснии и Герцеговине и в Косово) носят «двойную шляпу», являясь одновременно главами представительств Евросоюза. Они размещаются в соответствующих столицах. Остальные специальные представительства базируются в Брюсселе. Впрочем, Верховный представитель намеревается положить конец использованию модели «двойной шляпы» в феврале 2017 г., когда истекут мандаты трех представительств (данное предложение находится на рассмотрении в Комитете по политике и безопасности).

Описанная выше институциональная невнятица с положением спецпредставителей может провоцировать трения между Верховным представителем и Советом. Так, ещё в июле 2010 г. действительно разгорелись споры между Кэтрин Эштон и странами-участницами по поводу наметившейся отставки сразу нескольких спецпредставителей ${ }^{110}$. С подачи своего главного советника Роберта Купера, К. Эштон объявила о прекращении мандатов ряда спецпредставителей с февраля 2011 г., практически не уведомив государства-члены о таком

${ }^{110}$ The European Union as a Diplomatic Actor / Ed. by Joachim A. Koops and Gjovalin Macaj. - London: Palgrave Macmillan, 2015. P. 71. 
решении заранее, с тем, чтобы их работу продолжили делегации ЕС на местах или же сама ЕСВД в Брюсселе. Такое предложение встретило жесткую критику со стороны Совета. Страны Балтии, Финляндия, Швеция, Чехия, Румыния и Болгария настаивали на сохранении мандата спецпредставителя по урегулированию конфликта на Южном Кавказе. В результате был найден компромисс, и мандат спецпредставителя на Южном Кавказе был объединен с мандатом спецпредставителя ЕС в Грузии. На тот момент Эштон удалось упразднить несколько портфелей спецпредставителей (включая первого - в регионе Великих Африканских озёр) и передать их полномочия ЕСВД, однако дальнейшее развитие событий в Африке и на Ближнем Востоке побудило Совет ЕС, напротив, ввести новые мандаты для спецпредставителей в регионах Южного Средиземноморья, Африканского Рога, Сахеля и Ближнего Востока.

В 2013 г. Эштон предложила, чтобы институт специальных представителей был полностью интегрирован в ЕСВД, сохранив тесную связь с государствами-членами через Комитет по политике и безопасности. Она явно относилась к институту специальных представителей с подозрением. Могерини занимает в этом вопросе более компромиссную позицию и признаёт полезность сохранения данного инструмента. Несмотря на то, что Лиссабонский договор наделил Верховного представителя определёнными возможностями по назначению и смещению спецпредставителей, ситуация последних лет подтверждает, что если группа государств-членов настаивает на назначении спецпредставителя в определенный регион, Верховный представитель не в состоянии оказать этому решительное сопротивление.

Назначение спецпредставителей помогает ЕC более рационально расходовать бюджетные средства и человеческие ресурсы. Ведь изначально предполагалось, что Европейская служба внешнеполитических действий будет располагать большим числом сотрудников в своем штате, нежели вышло на самом деле. В результате ЕСВД оказалась перегружена разными задачами при недостаточном количестве кадров для их решения. При большей численности персонала, управляющие директора ЕСВД со временем, вероятно, могли бы взять на себя и функции спецпредставителей ЕС. Но на практике они оказались настолько поглощены текущей работой, что дополнительные миротворческие обязанности и регулярные командировки в регионы конфликтов оказались ЕСВД не под силу.

В Совете считают, что сохранение мандатов спецпредставителей ЕС резонно. В отличие от бюджета ЕСВД, который утверждает Европейский парламент, все расходы спецпредставителей контролируются Службой внешнеполитических инструментов - т.е. службой Комиссии. Несмотря на то, чтобы данная служба проверяет целесообразность расходования средств, спецпредставители все же обладают большой долей автономии в распределении своих бюджетов, что делает их, в восприятии представителей национальных правительств в Совете, более гибким и эффективным инструментом при посредничестве и урегулировании конфликтов.

Мандаты отдельных спецпредставителей существенно разнятся между собой, что отражает объём выделяемых им бюджетов. Эти средства покрывают все расходы, включая затраты по содержанию команды спецпредставителя, которая, как правило, состоит из экспертов по региону, политических советников (часть из них непременно базируется в Брюсселе и обеспечивает взаимодействие с институтами ЕС) и обслуживающего персонала, нанимаемого на месте, если спецпредставитель базируется за рубежом. Финансирование специальных представителей привязано к срокам их мандатов. В случае, если мандат продлевается, спецпредставитель получает новые средства на соответствующий период. Заинтересованные государства - члены ЕС также могут предложить командировать своих сотрудников в качестве членов команды спецпредставителя. 
Таблица 2-1

Специальные представители ЕС и их бюджет (по состоянию на октябрь 2016 г.) ${ }^{111}$

\begin{tabular}{|c|c|c|c|}
\hline $\begin{array}{c}\text { Специальный } \\
\text { представитель / страна } \\
\text { прочсхождения }\end{array}$ & Мандат & $\begin{array}{l}\text { Бюджет, } \\
\text { млн. евро }\end{array}$ & $\begin{array}{c}\text { Бюджетный } \\
\text { период }\end{array}$ \\
\hline $\begin{array}{l}\text { Франс-Микаэль Сколд Меллбин / } \\
\text { Дания }\end{array}$ & Афганистан & 7.625 & $\begin{array}{l}01.11 .2015- \\
28.02 .2017\end{array}$ \\
\hline Ларс-Гуннар Вигемарк / Швеция & $\begin{array}{c}\text { Босния } \\
\text { Герцеговина } \\
\end{array}$ & 7.6 & $\begin{array}{l}01.11 .2015- \\
28.02 .2017\end{array}$ \\
\hline Петер Буриан / Словакия & $\begin{array}{l}\text { Центральная } \\
\text { Азия }\end{array}$ & 0.81 & $\begin{array}{l}15.04 .2015- \\
30.04 .2016\end{array}$ \\
\hline Александр Рондос / Греция & $\begin{array}{l}\text { Африканский } \\
\text { Рог }\end{array}$ & 3.5 & $\begin{array}{l}01.11 .2015- \\
28.02 .2017\end{array}$ \\
\hline Ставрос Ламбринидис / Греция & Права человека & 0.788 & $\begin{array}{l}01.03 .2015- \\
29.02 .2016 \\
\end{array}$ \\
\hline Самуэль Збогар / Словения & Косово & 3.135 & $\begin{array}{l}01.11 .2015- \\
28.02 .2017\end{array}$ \\
\hline Фернандо Джентилини / Италия & $\begin{array}{l}\text { Ближневосточный } \\
\text { мирный процесс }\end{array}$ & 1.98 & $\begin{array}{l}15.04 .2015- \\
30.04 .2016\end{array}$ \\
\hline Анхель Лосада / Испания & Сахель & 1.77 & $\begin{array}{l}01.11 .2015- \\
28.02 .2017\end{array}$ \\
\hline Герберт Сальбер / Германия & $\begin{array}{l}\text { Южный Кавказ } \\
\text { и кризис в Грузии }\end{array}$ & 2.8 & $\begin{array}{l}01.11 .2015- \\
28.02 .2017\end{array}$ \\
\hline
\end{tabular}

Среди главных функций спецпредставителей ЕС можно выделить информационную, посредническую и финансовую. Представительские задачи, в свою очередь, возложены на глав делегаций ЕС. Делегации ЕС занимаются и всеми вопросами торгово-экономического сотрудничества. В первую очередь, спецпредставители являются «глазами и ушами» единой Европы в регионах своей работы. Спецпредставители тесно взаимодействуют с внутренними структурами ЕС и выступают координаторами при согласовании позиций всех участников процесса выработки внешнеполитический курс ЕС в отношении конкретной страны или региона. Сведения, которые передают спецпредставители непосредственно с места развития событий, особенно важны для тех стран ЕС, которые сами не располагают широкой сетью дипломатических ведомств за рубежом.

Ключевая функция спецпредставителей - посредничество в мирном урегулировании конфликтов. Они берут на себя посреднические функции в переговорах между конфликтующими сторонами, предлагают варианты разрешения противоречий и используют разные дипломатические методы. Если в регионе действует миссия ЕС, то спецпредставитель автоматически входит в её командный состав. Основываясь на своих наблюдениях и полученных сведениях, они готовят отчеты для Комитета по политике и безопасности. В своё время регулярные доклады спецпредставителя по региону Великих Африканских озёр и его присутствие в регионе конфликта помогли ЕС выработать единое видение ситуации, что было весьма непросто, так как бывшие колониальные державы Франция, Великобритания и Бельгия - имели там разнонаправленные интересы. В качестве ещё одного успешного примера здесь можно назвать выработку общей позиции ЕС по ситуации на Южном Кавказе, где между странами ЕС имелись противоречия ${ }^{112}$.

${ }^{111}$ EUISS Yearbook of European Security. YES 2016 / Paris: European Union Institute for Security Studies, 2016. P. 80.

112 Болгова И.В. Политика ЕС В Закавказье и Центральной Азии. Истоки и становление. М.: Навона, 2008. 
От лица единой Европы спецпредставитель участвует в переговорах с местными властями, поддерживает связи с послами третьих стран и международными организациями. Многие спецпредставители ЕС участвуют в международных координационных комитетах в зонах конфликтов, включая Афганистан, Боснию и Герцеговину, Косово, Южный Кавказ, Грузию.

В регионах командирования спецпредставители также сотрудничают с местными властями и организациями гражданского общества. Поддерживая процессы государственного строительства, демократической трансформации и становления новых институтов, они фактически оказываются вовлеченными в политические процессы на местах. Однако их влияние разнится от региона к региону. Наибольшим влиянием спецпредставители пользуются в странах Западных Балкан - Косово и Боснии и Герцеговине. В обеих странах спецпредставители ЕС выполняли дополнительные обязанности: в Боснии и Герцеговине представитель ЕС Валентин Инцко выступал в роли координатора международных усилий в рамках Дейтонских соглашений о мире 1995 г. по выполнению гражданских аспектов мирного урегулирования ${ }^{113}$, а в Косово спецпредставитель ЕС одновременно имел полномочия международного гражданского представителя. Его задачей было наблюдать за ходом выполнения «плана Ахтисаари» ${ }^{114}$. В отличие от своих коллег на Балканах, спецпредставители ЕС в других регионах не могут предложить странам, в которых они работают, прямую возможность вступления в ЕС, в силу чего их влияние на внутреннюю политику этих стран и на поддержание там процессов демократической трансформации менее существенно.

Ситуацией, которая продемонстрировала важность роли специальных представителей ЕС в зонах конфликта, стало подписание в 2011 г. декларации о независимости Южного Судана. Спецпредставитель ЕС оказывал непосредственное содействие бывшему президенту Южно-Африканской Республики Табо Мбеки в переговорах с представителями властей Судана и Южного Судана при подписании мирного соглашения ${ }^{115}$. Те функции, которые выполняют спецпредставители ЕС на местах, не могут сравниться с функциями делегаций ЕС или самой ЕСВД. Последние обладают меньшей гибкостью и недостаточной степенью автономии, чтобы выступать посредниками между конфликтующими сторонами или участвовать в процессах мирного урегулирования. Дипломатические успехи ЕС с применением инструмента спецпредставителей не подлежат сомнению, хотя напрямую эффективность их работы оценить сложно, так как многие детали деятельности спецпредставителей не подлежат обнародованию.

Результат работы спецпредставителей зависит не только от их дипломатических навыков, но и в значительной мере от их умения грамотно выстраивать отношения с институтами ЕС, которые вовлечены в формирование и проведение внешней политики ЕС. Сложная институциональная среда, с которой вынуждены взаимодействовать спецпредставители, может оказаться препятствием в их деятельности, равно как и подспорьем. При выполнении своих служебных обязанностей им приходится постоянно находиться в тесном контакте с соответствующими институтами и органами ЕС, в особенности с ЕСВД и Европейской комиссией.

113 Соглашение о мире в Боснии и https://ria.ru/spravka/20101121/296950694.html.

${ }^{114}$ Бывший президент Финляндии Марти Ахтисаари, будучи специальным посланником ООН, подготовил в 2007 г. доклад, так называемый «план Ахтисаари», который предполагал независимый статус Косово под международным контролем. Москва не поддержала этот план. «Схема отложенной автоматической независимости Косова для нас неприемлема», - заявил министр иностранных дел России Сергей Лавров. См.: Лавров раскрыл план Ахтисаари. 12 июля 2007. URL: http://vz.ru/politics/2007/7/12/93913.html.

${ }^{115}$ Zwan J. Evaluating the EU's Role and Challenges in Sudan and South Sudan: Sudan and South Sudan Case Study // International Alert. London, 2011. URL: http:/www.internationalalert.org/sites/default/files/publications/092011IfPEWSudan_0.pdf. 
Как уже отмечалось выше, спецпредставителей назначает Совет ЕС по иностранным делам, но фактически свое взаимодействие с Советом спецпредставители осуществляют через Комитет по политике и безопасности - именно он осуществляет стратегическое и политическое руководство деятельности спецпредставителей. Рабочие группы Совета ЕС по внешней политике, которые состоят их национальных дипломатов, возглавляемых чиновниками из ЕСВД, внимательно следят за работой спецпредставителей и, совместно с Верховными представителем, могут поставить вопрос о прекращении, продлении или создании новых мандатов.

В своей повседневной работе спецпредставители также взаимодействуют с Комиссией, поскольку последняя по-прежнему отвечает за широкий спектр внешнеполитических вопросов. Именно Комиссия может принять решение о финансировании тех или иных инициатив спецпредставителей. Меньше внимания в своей работе спецпредставители уделяют взаимодействию с Европейским парламентом: если бюджет ЕСВД утверждается с одобрения Парламента, то финансирование спецпредставителей осуществляется через специальную Службу внешнеполитических инструментов. Иными словами, ЕП не имеет такого рычага, как финансовый контроль над спецпредставителями. Тем не менее, с 2010 г. перед вступлением в должность спецпредставители официально выступают перед парламентским комитетом по иностранным делам и также регулярно информируют данный комитет о результатах своей деятельности.

Специальные представители ЕС вносят немалый вклад в выработку единой внешней политики ЕС, осуществляют информирование и координацию стран-участниц ЕС по вопросам, касающихся ситуаций в их регионе, устанавливают контакты с другими акторами, включая местные власти, третьи страны и международные организации. Специальные представители не раз доказал эффективность своей работы при урегулировании конфликтов, поэтому уже более двадцати лет они остаются важным и весьма гибким дипломатическим инструментом в распоряжении Совета ЕС. Даже после вступления в силу Лиссабонского договора специальные представители не утратили своей значимости. Специальных представителей больше ценят государства-члены, нежели институты ЕС (их статус относительно ЕСВД остаётся несколько неопределённым). 


\section{Глава 3 \\ ПОЛИТИКИ}

\section{§ 3.1 ТОРГОВАЯ ПОЛИТИКА}

Европейский союз, взятый в целом, является крупнейшей экономикой мира. Его ВВП в 2014 г. составил 13920541 млн. евро (больше, чем у США). Это крупнейший в мире торговый блок, занимающий первое место в торговле промышленными товарами и услугами, а также в сфере инвестиций (как входящих, так и исходящих). Это важнейший торговый партнёр для 80 стран мира (для сравнения: Соединённые Штаты являются первым торговым партнёром примерно для 20 стран). В частности, Евросоюз активно торгует с развивающимися странами, импортируя оттуда больше, чем США, Канада, Япония и Китай, вместе взятые ${ }^{116}$. Евросоюз является крупнейшим торговым визави для таких стран, как Бразилия, Индия, Китай, Россия, Южная Африка и США. В таком качестве, ЕС заинтересован в подержании стабильной и гармоничной внешней среды, благоприятствующей его процветанию и позволяющей избегать такого рода конфронтационной политики, которая притягивает к себе проекты строительства мирового порядка иного плана, в большей мере ориентированные на баланс сил.

Наднациональная торговая политика появилась у западноевропейского интеграционного объединения очень давно. Она отнесена к исключительной компетенции европейских институтов. Уже в Римском договоре 1957 г., на основании которого было учреждено Европейское экономическое сообщество (ЕЭС), вопросы торговли были отданы на европейский уровень. Установление общего внешнего тарифа для всего ЕЭС, продвижение торговой либерализации в отношениях с третьими странами и применение доступных защитных мер были необходимым внешним компонентом заработавшего в 1960-е годы Таможенного союза.

Здесь в полной мере продолжает действовать «метод Сообщества» (Community method). Это значит, что интересы ЕС в торговых переговорах с третьими странами представляет Комиссия, в частности - её Генеральный директорат по торговле, насчитывающий свыше 600 сотрудников. Двусторонние соглашения между государствами-членами ЕС и третьими странами допускаются только в том случае, если Евросоюз даёт на это своё специальное согласие. Его компетенция распространяется не только на торговлю товарами, но и на торговлю услугами, а также «коммерческие аспекты» прав интеллектуальной собственности (за исключением исполнения уголовно-правовых предписаний) и прямые иностранные инвестиции. С точки зрения Комиссии, исходя из договорных положений по свободному движению капитала, её власть распространяется и на портфельные инвестиции ${ }^{117}$, с чем склонны в целом согласиться Совет и ЕП при некоторых сомнениях, высказываемых со стороны ряда государств-членов. Общая торговая политика (ОТП) - одна из наиболее интегрированных областей хозяйственно-политической деятельности в ЕС. Квалифицированное большинство при голосовании является общим правилом в Совете министров ЕС при принятии решений по всем аспектам ОТП - за некоторыми отдельными

\footnotetext{
$116 \mathrm{http} / / /$ ec.europa.eu/trade/policy/eu-position-in-world-trade.

117 European Commission (2010), Communication "Towards a comprehensive European international investment policy", COM final of 7.7.2010. P. 8 .
} 
исключениями. Инструментами торговой политики ЕС выступают тарифы, квоты, добровольные экспортные ограничения, антидемпинговые меры и торговые санкции ${ }^{118}$.

Лиссабонский договор, в частности, многократно усилил ту роль, которую в торговой политике играет Европейский парламент. Все односторонние решения европейского уровня (базовые акты) в рассматриваемой области (включая меры торговой защиты и торговые преференции) должны проходить через слушания в ЕП для их принятия. Все торговые соглашения (и двусторонние, и многосторонние), заключаемые EC, нуждаются в парламентском одобрении. Помимо этого, Комиссия должна регулярно отчитываться перед ЕП (точнее, перед парламентским Комитетом по международной торговле) о ведущихся ею торговых переговорах.

Согласно принятым в ЕС процедурным правилам, цели торговых переговоров с третьими странами устанавливаются Советом министров на основании предложения Комиссии, которое она представляет в сформированный Советом межправительственный Комитет по торговле (КТ - бывший Комитет 133 статьи). Он объединяет старших национальных должностных лиц по торговым вопросам. Стараясь достичь консенсуса, КТ изучает предложение и может вносить в него изменения, а затем передает его в Комитет постоянных представителей стран ЕС в Брюсселе (КОРЕПЕР) - орган, ассистирующий Совету, и, в конечном счете, в сам Совет. Ранние стадии обсуждения проходят за закрытыми дверями, чтобы скрыть переговорные цели ЕС от торговых партнеров.

Совет (по рекомендации Комиссии) принимает решение о выдаче ей мандата на ведение переговоров, действуя квалифицированным большинством. Единогласное решение Совета отныне предусмотрено только в отношении торговых переговоров и заключения соглашений в сфере торговли услугами и коммерческих аспектов интеллектуальной собственности, а также прямых иностранных инвестиций, но только если подобные соглашения включают позиции, по которым единогласие требуется для принятия в Евросоюзе внутренних правил. Единогласие допускается также в тех случаях, когда европейские обязательства по линии культурных услуг грозят подорвать многообразие в культуре интегрированной Европы, в том числе лингвистическое, или когда обязательства ЕС по социальным, образовательным и медицинским услугам могут серьезно нарушить национальную организацию предоставления подобных услуг и помешать национальной власти их оказывать.

Сами торговые переговоры, как уже сказано выше, ведет Комиссия, которая, однако, постоянно консультируется по ходу дела с государствами-членами. КТ пристально следит за переговорами, а команда непосредственных переговорщиков от ЕС постоянно контактирует с национальными представителями. ЕК информирует также Комитет по международной торговле Европарламента.

Результаты переговоров парафируют переговорщики, затем они получают одобрение в Совете (при необходимости Совет может предложить применять одобренное соглашение на временной основе). После того как Европарламент даст свое согласие (ЕП при этом голосует простым большинством), Совет подписывает соглашение (иными словами, он должен принять еще и второе решение о формальном заключении соглашения). На практике, вопреки возобладавшему правилу квалифицированного большинства при голосовании в Совете, все стадии принятия торговых решений, которые проходят внутри Евросоюза, попрежнему характеризуются преимущественным стремлением достичь и поддерживать консенсус между государствами-членами.

Наряду с многосторонними переговорами и двусторонними соглашениями, третьей «опорой» общей торговой политики Евросоюза необходимо назвать те инструменты,

\footnotetext{
${ }^{118}$ Подробнее по этому вопросу см.: Prytula N.V. Instruments of Foreign Trade Policy of the European Union // ECONOMICS: time realities. 2015. No2 (18). URL: http://cyberleninka.ru/article/n/instruments-of-foreign-tradepolicy-of-the-european-union.
} 
которыми он пользуется в одностороннем порядке и изо дня в день, чтобы защитить Единый внутренний рынок от «недобросовестной» конкуренции со стороны торговых партнеров или от внезапно возросшего импорта. В соответствии с правилами ВТО, у ЕС есть три таких инструмента - антидемпинговые (наиболее часто и все активнее используемые), компенсационные и специальные защитные меры.

Переговоры по смешанным соглашениям ${ }^{119}$ также ведёт Комиссия, но процедура ратификации более сложная: в этом случае требует согласие не только ЕП, но и каждого национального парламента.

Осуществление торговой политики изо дня в день делегировано Советом ЕС Европейской комиссии, в компетенции которой выработка торговых правил и ведение двусторонних и многосторонних торговых переговоров. При этом государства-члены сохраняют мощные контрольные механизмы за собой. Разрешение на начало переговоров Комиссия должна получить у Совета. В ходе переговоров за её действиями пристально наблюдает специальный комитет (Комитет по торговой политике), состоящий из представителей государств-членов. В случае успешного завершения переговоров достигнутое соглашение должно получить одобрение в Совете. Несмотря на то, что по формальным правилам для такого одобрения требуется квалифицированное большинство голосов, на деле Совет всегда принимает подобные решения единогласно, фактически наделяя каждое государство-член правом вето.

Общая торговая политика ЕС развивалась под большим влиянием как внутренних (его собственная регуляторная система и acquis communautaire), так и международных факторов (прежде всего, многосторонние переговоры в рамках ГАТТ/ВТО).

Развивающимся странам ЕС предлагает невзаимный рыночный доступ в форме сниженных тарифов на их товары при попадании на европейский рынок. Речь идёт об общей системе преференций (Generalized System of Preferences), действовавшей с 1971 г., которая с 2014 г. регулируется регламентом № 978/2012 120. Согласно этому регламенту, предоставление соответствующих преференций может быть приостановлено Евросоюзом по следующим обстоятельствам: серьёзное и систематическое нарушение прав человека и трудовых прав; экспорт товаров, произведённых заключёнными; торговые практики, подрывающие справедливые условия торговли; подрыв целей региональных рыболовных организаций и иных международных договорённостей.

В результате реформы количество стран, пользующихся таким преимуществом, было сокращено (в связи с ростом доходов на душу населения в этих странах) с 178 до 92. В том числе снижение пошлин на определённые группы товаров больше не распространяется на такие страны, как Россия, Беларусь и Казахстан, но сохранено для Индии и Китая.

Система GSP предусматривает три режима:

(1) стандартный преференциальный режим $(G S P)^{121}$;

(2) режим дополнительных тарифных преференций для стимулирования устойчивого развития $(G S P+)^{122}$;

(3) режим доступа на рынок ЕС без пошлин и квот для всех товаров, кроме оружия, происходящих из 49 наименее развитых стран $(E B A)$.

Режим $G S P+$, требующий от стран, им пользующихся, выполнения политических обязательств, оснащён системой мониторинга, который осуществляют ЕСВД и службы

\footnotetext{
${ }^{119}$ К смешанным соглашениям относят такие соглашения, в которых одновременно участвуют и Европейский союз и одно или более из его государств-членов. Соглашение также может рассматриваться как смешанное, если в нём речь идёт о вопросах, относящихся к смешанной компетенции ЕС и государств-членов.

${ }^{120}$ URL: http://trade.ec.europa.eu/doclib/docs/2012/october/tradoc_150025.pdf.

121 Данный режим действует в отношении 29 стран, но в Европе он распространён только на Украину.

122 Получение преференций обставлено дополнительными условиями, касающимися соблюдения прав человека, основных трудовых стандартов, охраны окружающей среды и эффективного управления. Данный режим действует в отношении 14 стран, включая Армению и Грузию.
} 
Комиссии. К ноябрю 2017 г. Комиссия должна отчитаться перед ЕП и Советом о действии данной системы в отношении стран-бенефициаров ${ }^{123}$. За пределами системы GSP тарифные преференции предоставляются в форме автономных торговых мер (Autonomous Trade Measures) шести странам Западных Балкан с 2000 по 2016 гг. ${ }^{124}$.

В то же время ЕС активно прибегает к услугам органа по разрешению споров в ВТО (WTO Dispute Settlement Body ${ }^{125}$ ). В частности, Европейская комиссия с 2012 г. (со времени вступления России в ВТО) в рамках соответствующей процедуры запрашивала консультации с Россией в нескольких случаях:

(1) по утилизационным сборам на транспортные средства;

(2) по мерам, влияющим на импорт живых свиней, свинины и других продуктов из свинины;

(3) по антидемпинговым пошлинам на лёгкие коммерческие автомобили из Германии и Италии;

(4) по расчёту импортных пошлин на определённые сельскохозяйственные и промышленные товары ${ }^{126}$.

Краеугольным камнем торговой политики ЕС в настоящее время принято называть приверженность устранению торговых барьеров, включая экспортные налоги. На глобальной арене Евросоюз, чтобы обеспечить себе более широкий и надёжный доступ к дешёвому сырью, добивается либо запрета на экспортные налоги, либо введения серьёзных ограничений на способность развивающихся стран взимать либо повышать таковые. Между тем многие развивающиеся страны облагают налогами или другими ограничениями свой сырьевой экспорт, чтобы повысить доходы государственного бюджета, развивать местную перерабатывающую отрасль или защищать окружающую среду. С точки зрения ЕС, подобные меры являются «контрпродуктивными», а развивающимся странам следует, напротив, делать всё возможное для максимизации своего экспорта ${ }^{127}$.

В отличие от большинства стран, ЕС ищет не только негативной интеграции в международной торговле (т.е. устранения торговых барьеров ${ }^{128}$ ), но и позитивной интеграции (выработки общих антимонопольных правил, а также правил, регулирующих государственные закупки, инвестиционную сферу и вопросы защиты окружающей среды и трудовых стандартов), которые согласовывались бы на глобальном уровне - прежде всего в ВТО. Но предложения ЕС по позитивной интеграции мирового рынка встречают стойкое сопротивление развивающихся стран и не имеют достаточной поддержки стран развитых.

Не следует обходить вниманием и вопрос легитимности общей торговой политики EC. Как было показано выше, процесс принятия решений в этой области отличается повышенной секретностью. Обсуждения в рамках Комитета по торговле Совета являются

${ }^{123}$ Report on the Generalised Scheme of Preferences covering the period 2014-2015. Report from the Commission to the European Parliament and the Council. Brussels, 28.1.2016. URL: http://trade.ec.europa.eu/doclib/docs/2016/january/tradoc_154180.pdf.

${ }^{124}$ European Commission online information, "Autonomous trade measures".URL:

http://ec.europa.eu/enlargement/policy/glossary/terms/association-trade-measures_en.htm.

${ }^{125}$ Сизов Алексей. Разрешение споров по правилам ВТО: международный опыт и российские перспективы. 18.06.2013. URL: http://www.kiaplaw.ru/press-centr/mneniya-ekspertov/

${ }^{126}$ Баева М.А. Торговые споры в рамках ВТО, в которых участвует Россия, и механизм из разрешения // Российский внешнеэкономический вестник. 2015. № 3. C. 75-90. [Electronic resource].Mode of access: http://www.rfej.ru/rvv/id/e002c9819/\$file/75-90.pdf.

${ }^{127}$ Подробнее см.: Curtis Mark. The New Resource Grab: How EU Trade Policy on Raw Materials is Undermining Development. Aitec/Comhlámh/Oxfam,Germany/Traidcraft/WEED, November $2010 . \quad$ URL: http://curtisresearch.org/publications/the-new-resource-grab-how-eu-trade-policy-is-undermining-development/

128 Стремление ЕС к либерализации правил международной торговли не распространяется на продукцию сельского хозяйства, текстильной промышленности и одежду. См.: Heron T. European Trade Diplomacy and the Politics of Global Development: Reflections on the EU-China "Bra Wars" Dispute // Government and Opposition. 2007. Vol. 42. № 2. P. 190-214. 
закрытыми, что мешает парламентариям и гражданскому обществу эффективно контролировать принимаемые решения. В ходе международных торговых переговоров детали предложений и содержание переговорного мандата Комиссии остаются не известными даже государствам-членам. Здесь же уместно вспомнить постоянную критику со стороны неправительственных организаций по поводу того, что решения в общей торговой политике ЕС обычно принимаются в угоду крупным производителям.

Наконец, подъём новых торговых держав (Бразилия, Россия, Индия и особенно Китай) способствовал изменениям в международной торговой системе. В ЕС с беспокойством ожидают, что в будущем это приведёт к дальнейшему усложнению многосторонних переговоров по вопросам торговли. С такими ожиданиями связан возросший интерес Союза к двусторонним торговым соглашениям.

Дохийский раунд переговоров в рамках ВТО, стартовавший в 2001 г., выявил непреодолимые разногласия между Западом и развивающимися странами. Ответственность за это следует в большей мере возложить на страны развитые. США и Евросоюз в рамках Дохийского раунда, который застопорился, начиная с 2005 г., добивались устранения тарифов на автомобили и продукцию фармацевтики, но не торопились открывать собственные сельскохозяйственные рынки. Свободная торговля, без сомнения, приносит выгоду потребителям по всему миру. Но торговля - это также и политический вопрос, в котором сталкиваются особые интересы. Поэтому, начиная с 2006 г., стратегия «Глобальная Европа» открыла очередной этап в торговой политике ЕС, определивший его разворот к заключению с важными партнёрами двусторонних соглашений нового поколения о свободной торговле. Первое из таких соглашений (между Евросоюзом и Республикой Корея) вступило в силу в 2011 году.

Двусторонние торговые соглашения Евросоюза можно классифицировать следующим образом: (1) соглашения со странами Европейского экономического пространства (Исландия, Норвегия, Лихтенштейн) плюс Швейцария, (2) соглашения в рамках ЕвроСредиземноморского партнёрства, (3) соглашения об ассоциации с EC, (4) соглашения с развивающимися странами и (5) преференциальные торговые соглашения.

К числу последних отнесём соглашение ЕС-Канада о торгово-экономическом сотрудничестве (CETA), которое было подписано 30 октября 2016 г. и находится на ратификации. Уточним, что сначала саммит ЕC - Канада, где должно было пройти подписание этого соглашения, был запланирован на 27 октября 2016 г., но затем был отложен, поскольку соглашение заблокировала Бельгия (против него выступил парламент франкоязычной Валлонии, который 28 октября снял свои возражения, достигнув согласия с федеральным правительством страны ${ }^{129}$ ).

Переговоры ЕС-США о Трансатлантическом торговом и инвестиционном партнёрстве (ТТИП), начатые в 2013 г., пока не завершены. С победой на президентских выборах в США кандидата от Республиканской партии Дональда Трампа, который заявлял о намерении пересмотреть в протекционистском духе как действующие, так и пока ещё не вступившие в силу торговые соглашения США, решение этого вопроса отодвигается в неопределённое будущее.

Торговое соглашение по борьбе с контрафактной продукцией (Anti-Counterfeiting Trade Agreement, ACTA) - пример плюрилатеральных договоров (в них участвуют не все члены ВТО). В этом вопросе Комиссия достигла соглашения с ограниченным числом торговых партнёров (в данном случае ЕС поддержал инициативу США и Японии). Переговоры проходили в 2008-2010 гг. К ним присоединились Швейцария, Мексика, Сингапур, Австралия, Новая Зеландия и Республика Корея. Но в итоге соглашение было

\footnotetext{
${ }^{129}$ Выраженные им озабоченности касались международного арбитража и сельскохозяйственных аспектов. По бельгийской конституции, прежде чем такой документ может одобрить правительство Бельгии, с ним должны согласиться все три региона страны - Валлония, Фландрия и Брюссель.
} 
отвергнуто ЕП в июле 2012 г., что, в конечном счёте, его и «похоронило». Волну протестов в Восточной Европе и Германии, в частности, вызвала одна из статей соглашения - о защите интеллектуальной собственности в интернете. Согласно данной статье, провайдеры услуг в сети должны были бы предоставлять сведения о пользователях не по решению суда, а по требованию административных органов.

Таким образом, у нас нет оснований усомниться в том, что Евросоюзу в сфере международной торговли принадлежит одна из ведущих ролей. Торговая политика, без сомнения, относится к числу его ключевых внешнеполитических инструментов. Но в последние годы торговые партнёры ЕC начинают высказывать сомнения в его договороспособности. Основанием для этого служат, в частности, упомянутые выше эпизоды.

В зависимости от используемых экспертами критериев, рынок ЕС называют крупнейшим либо вторым крупнейшим (после США) рынком в мире. Он имеет огромную притягательную силу для третьих стран. Опасение быть исключенным с этого рынка, как и надежда получить привилегированный доступ на него, во многих случаях побуждают третьи страны, в особенности экономически менее сильные, внимательно прислушиваться к его требованиям либо даже уступать им - причём не только по торговым вопросам, но и по политическим. Поэтому справедливым следует признать мнение о том, что Евросоюз «использует доступ на свой рынок с целью произвести изменения на внутренней арене стран, являющихся его торговыми партнёрами, начиная с вопросов трудовых стандартов и заканчивая политикой развития, и на международной арене, начиная с глобального управления и заканчивая внешней политикой» ${ }^{130}$. Доступ к ЕС как крупнейшему в мире рынку составляет фундамент его нормативной власти во внешней политике. Поскольку торговая политика стала важным направлением внешней политики ЕС, мы можем поэтому согласиться с мнением о том, что он является внешнеполитическим актором, отчасти «действуя с чёрного хода» 131.

Евросоюз сыграл одну из ключевых ролей в основании ВТО в 1994 г. Его можно назвать твёрдым приверженцем многосторонней системы управления мировой торговлей. Но ввиду обозначившейся сложности достижения общего согласия на глобальном уровне ЕС готов идти вперёд с теми участниками ВТО, кто проявляет к этому достаточный интерес (в качестве, по крайней мер, временного решения).

\footnotetext{
${ }^{130}$ Meunier S., NicolaidisK. The European Union as a conflicted trade power // Journal of European Public Policy. 2006. Vol. 13. № 6. P. 906.

${ }^{131}$ Meunier S., NicolaidisK. The European Union as a conflicted trade power. International relations and the European Union. New York: Oxford University Press, 2011. P. 275-298.
} 


\section{§ 3.2 ПОЛИТИКА РАЗВИТИЯ}

Политика развития выросла из соглашений о сотрудничестве и ассоциации ЕЭС с бывшими колониями государств-членов и прежде всего - Яундских и Ломейских конвенций ${ }^{132}$. В 1950-1980-е годы она трактовалась в ЕС как «естественное партнёрство», а участвующие в нём стороны - как равные друг другу. Она отличалась политической нейтральностью и подчинялась принципу невмешательства во внутренние дела. Однако в 1980-1990-е годы Евросоюз воспринял Вашингтонский консенсус по поводу принципов экономической политики (предоставление помощи стали подчинять, прежде всего, определённым экономическим условиям). Начиная с 2000-х годов, помощь стала обусловливаться стремлением стран-получателей к достижению целей, согласованных совместно с ЕС (или под его давлением).

В ноябре 2000 г. ЕК и Совет совместно приняли Декларацию по политике развития ${ }^{133}$, которая установила её главную цель (сокращение бедности). Приоритет в предоставлении средств был отдан развивающимся странам с низкими доходами. Для ЕС (в отличие от государств-членов) была признана необходимость сфокусироваться на таких сферах деятельности, как связь между торговлей и развитием, региональная интеграция, макроэкономическая поддержка, транспорт, городское развитие, здравоохранение, образование, институциональный потенциал. В 2005 г. ЕК, Совет и ЕП приняли новый документ под названием «Европейский консенсус в вопросах развития» ${ }^{134}$. В нём они отстаивали роль ЕС, отличную от автономных программ стран-участниц, подтвердили акцент на помощи самым бедным странам развивающегося мира, а странам со средним уровнем развития - только при наличии у них серьёзных проявлений неравенства, и расширили список сфер деятельности ЕС, включив в него дополнительно водоснабжение, энергетику, сельское хозяйство, здравоохранение, социальное сплочение и вопросы занятости. В нём также подчёркивалось, что ЕС придерживается многостороннего подхода, т.е. в рамках ООН содействует продвижению системы правил, институтов и международных инструментов, созданных международным сообществом. Наконец, принятый в 2007 г. добровольный Кодекс поведения ${ }^{135}$ упорядочил разделение труда между государствамичленами и самим Евросоюзом.

В этот период и произошло усиление политического компонента в диалоге ЕС с развивающимися странами: он используется для обсуждения таких вопросов, как мир и безопасность, предотвращение и разрешение конфликтов, прогресс в обеспечении прав человека и демократизации, институциональные изменения и административные реформы, борьба с терроризмом и распространение оружия массового уничтожения. Кроме того, большое значение при планировании стратегий развития отдельных стран ЕС придаёт участию их неправительственных организаций, частного сектора, а также региональных и местных властей. Предоставление помощи основывается не только на оценке потребностей

\footnotetext{
132 Подробнее см.: Подбиралина Г.В. Организационные и экономические аспекты сотрудничества ЕС и африканских стран // Вестник PЭA. 2008. № $1 . \quad$ P. $103-107 . \quad$ URL: http://rus.neicon.ru:8080/xmlui/bitstream/handle/123456789/7032/20_\%D0\%9F\%D0\%BE\%D0\%B4\%D0\%B1\%D0\%B $8 \% \mathrm{D} 1 \% 80 \% \mathrm{D} 0 \% \mathrm{~B} 0 \% \mathrm{D} 0 \% \mathrm{BB} \% \mathrm{D} 0 \% \mathrm{~B} 8 \% \mathrm{D} 0 \% \mathrm{BD} \% \mathrm{D} 0 \% \mathrm{~B} 0 . \mathrm{pdf}$ ? sequence=1.

${ }_{133}$ Development Policy Statement. URL: http://ec.europa.eu/development/body/legislation/docs/council_statement.pdf. 134 European Consensus on Development/ URL: - http://eurlex.europa.eu/LexUriServ/LexUriServ.do?uri=OJ\%3AC\%3A2006\%3A046\%3A0001\%3A0019\%3AEN\%3APDF.

${ }^{135} \mathrm{EU}$ Code of Conduct on Division of Labour in Development Policy. [COM(2007) 72 final - Not published in the Official Journal]. [Electronic resource]. Mode of access: http://eur-lex.europa.eu/legalcontent/BG/TXT/?uri=uriserv:r13003.
} 
каждой страны, но и на том, как в этой стране справляются с использованием поступающих средств $^{136}$.

Парадоксы в нынешней организации европейской внешней политики хорошо просматриваются на следующем примере, связанном с решениями Суда ЕС. Операции по разминированию, проводимые в развивающихся странах, в 2001 г. перенесли из ОВПБ в область функционирования Европейского сообщества ${ }^{137}$, тогда как правовая база в вопросах борьбы с незаконным распространением стрелкового оружия и лёгких вооружений оставляла вопросы, с которыми в 2008 г. разбирался Суд ЕС ${ }^{138}$, в сфере ОВПБ. В данном случае для имплементации совместного действия по борьбе с распространением стрелкового оружия и лёгких вооружений Совет в рамках ОВПБ принял решение поддержать соответствующие инициативы Экономического сообщества государств Западной Африки (ЭКОВАС). В ходе обсуждений, предшествовавших принятию этого решения, Комиссия стала настаивать, что оно должно быть принято в рамках коммунитарной политики развития, и выступила с законодательным предложением сходного содержания. Впоследствии Комиссия обратилась в Суд ЕС с иском об аннулировании решения Совета. В результате Судом ЕС это решение действительно было аннулировано, поскольку оно основывалось на договорных положениях об ОВПБ, тогда как статья 47 Маастрихтского договора 1992 г. запрещала использовать эту правовую базу при принятии решений, для которых имеются правовые основания в рамках (наднациональной) первой опоры. Но в Лиссабонском договоре нет статьи, аналогичной статье 47 Маастрихтского договора. Иными словами, теперь - в подобной ситуации Комиссия вряд ли могла бы настоять на своём, обратившись в Суд ЕС.

Таким образом, вывод Комиссии о недостаточной согласованности политики развития и ОПБО в известной мере сохраняет актуальность ${ }^{139}$. Такого рода прямые столкновения, как стычка Советом и Комиссией по поводу поддержки действий ЭКОВАС, описанная выше, возникают нечасто. Но более мелкие трения между институтами, тем не менее, продолжают отвлекать время и энергию задействованных институциональных игроков от усилий по эффективной реализации европейского внешнеполитического курса.

В сфере сотрудничества в вопросах помощи международному развитию в распоряжении у Евросоюза имеются три долговременных географических инструмента (Инструмент соседства ${ }^{140}$, Европейский фонд развития, Инструмент сотрудничества в вопросах развития ${ }^{141}$ ) и два отраслевых инструмента (Европейский инструмент поддержки демократии и прав человека ${ }^{142}$ и Инструмент стабильности $)^{143}$.

Европейский фонд развития (European Development Fund) - главный инструмент предоставления помощи бывшим европейским колониям: 79 странам Африки, Карибского

\footnotetext{
${ }^{136}$ Carbone M. Mission Impossible: The European Union and Policy Coherence for Development // Journal of European Integration. 2008. Vol. 30. № 3. P. 323-342.

${ }^{137}$ Regulation (1724/2001/EC) of 23 July 2001 concerning action against anti-personnel landmines in developing countries, (Sept. 1, 2001), OJ L234/1.

${ }^{138}$ European Commission Legal Service. Summaries of Important Judgments. C-91/05 Commission v Council, Judgment of 20 May 2008. [Electronic resource].Mode of access: http://ec.europa.eu/dgs/legal_service/arrets/05c091_en.pdf.

${ }^{139}$ Thematic Evaluation of European Commission Support to Conflict Prevention and Peace-Building. 2011.P. 94. [Electronic resource]. Mode of access: http://ec.europa.eu/europeaid/how/evaluation/evaluation_reports/reports/2011/1291_vol4_en.pdf.

140 Предоставляет средства на условиях совместного финансирования в целях продвижения должного управления, а также социального и экономического развития.

141 Финансирует сотрудничество с развивающимися странами, на которые не распространяются другие финансовые инструменты, а также тематические программы для всех развивающихся стран.

142 Согласно своему названию, поддерживает защиту прав человека и развитие демократии в тех странах, где они находятся под угрозой. Это гибкий инструмент, который позволяет ЕС оказывать прямую поддержку гражданскому обществу в странах, с которыми у него нет соглашения о помощи в целях развития.

${ }^{143}$ Подробнее см.: Bartelt S. The Institutional Interplay Regarding the New Architecture for the EC's External Assistance // European Law Journal. 2008. Vol. 14. № 5. P. 655-679.
} 
бассейна и Тихого океана $(\text { АКТ })^{144}$, а также заморским странам и территориям (эта помощь предоставляется в соответствии с Соглашением Котону о партнёрстве 2000 г., заключенным на двадцатилетний период ${ }^{145}$ ). Средства в ЕФР поступают напрямую от государств-членов. Он не входит в бюджет ЕС, но переговоры в Совете по различным его элементам проводятся параллельно с переговорами по бюджетным инструментам общей внешней политики. На период 2014-2020 гг. средства Фонда составляют 30.5 млрд. евро.

Торговые отношения ЕС со странами АКТ регулируются соглашениями об экономическом партнёрстве (Economic partnership Agreements), в которых задействованы несколько межрегиональных конфигураций, включая CARIFORUM ${ }^{146}$ - соглашение о создании зоны свободной торговли между Европейским союзом, пятнадцатью членами Карибского сообщества (КАРИКОМ) и Доминиканской Республикой было подписано в 2008 г,

В Соглашении Котону 2000 г. определены политические, технические и демократические условия, которые страны АКТ должны выполнять в обмен на помощь. Это обеспечивает определенные рамки для обеих сторон в том, что касается соблюдения фундаментальных прав. Предусмотрен определённый период консультаций (до двух месяцев) на тот случай, когда эти права нарушаются. Согласно статье 97 Соглашения, если консультации не приносят искомого результата, либо в «случаях, вызывающих опасения», страны-доноры вправе прибегнуть к «соответствующим действиям», включая приостановку финансирования, для выправления ситуации. Как показывает практика, подобная реакция со стороны ЕС обычно следует лишь в ответ на подрыв демократического порядка.В данном смысле к «случаям, вызывающим опасения», следует отнести государственный переворот на Мадагаскаре 2009 г. и аналогичные события в Зимбабве («дворцовый переворот» 2015 г.), Того (2004 г.), Гвинее-Бисау (военный переворот 2003 г.).

Там, где вызовы безопасности подрывают действия ЕС по линии политики развития, все названные инструменты используются для прямого финансирования действий, направленных на решение проблем безопасности, таких как проведение в странахполучателях военной реформы, разоружения, демобилизации и реинтеграции общества, а также гражданской обороны.

Два финансовых инструмента, находящихся в руках Комиссии, прямо нацелены на место стыковки политики развития с ОПБО. Это Механизм по миру в Африке (African Peace Facility $^{147}$ ), учреждённый в 2004 г. в ответ на соответствующее предложение африканских лидеров на саммите 2003 г. Африканского союза в Мапуто (Мозамбик). По этой линии выделено 740 млн. евро для миссий, осуществляемых самим африканцами, в том числе на поддержку миссий Африканского союза в Сомали и в Судане и миссии Экономического сообщества государств Центральной Африки по консолидации мира в Центральноафриканской Республике (MICOPAX), а также действий по операционализации различных элементов африканской региональной архитектуры поддержания мира и безопасности $^{148}$ и первых стадий посреднических действий и миссий по прояснению фактического состояния дел, которые проводятся в рамках миротворческой деятельности либо Африканским союзом, либо региональными экономическими сообществами Африки (Механизм по миру в Африке финансируется из Европейского фонда развития).

Второй подобный инструмент - это уже упомянутый выше Инструмент в поддержку стабильности. Его функция отчасти состоит в обеспечении связки между ОПБО и мерами по

\footnotetext{
${ }^{144}$ На эти страны в общем объёме внешней торговли ЕС приходится около 5\%.

145 Переговоры о внесении в него изменений проходят каждые пять лет.

${ }^{146} \mathrm{http}$ //offshore.su/blog/offshore_news/soglashenie-kariforuma-o-svobodnoj-torgovle-pojdet-na-polzu.html.

${ }^{147} \mathrm{http}: / /$ www.africa-eu-partnership.org/en/success-stories/african-peace-facility.

148 Об африканской региональной архитектуре поддержания мира и безопасности см., например, по адресу: http://www.eurasialegal.info/index.php?option=com_jcontentplus\&view=article\&id=2997:

1\&catid=116:2011-09-19-12-34-31
} 
линии политики развития ЕС применительно к тем странам, которые стали или рискуют стать жертвами кризисов либо природных катастроф ${ }^{149}$. У данного инструмента есть краткосрочный компонент (помощь в восстановлении базовых условий для сотрудничества) и долгосрочный компонент (последний действует там, где имеются стабильные условия для сотрудничества на местах, обеспечивая техническую и финансовую помощь в поддержании закона и порядка, критически значимую инфраструктуры и здравоохранения). Таким образом, Комиссия, помимо своей более традиционной роли в политике развития ЕС, занимается разными инструментами, имеющими отношение к возникающим в данной связи аспектам безопасности.

Уже в 2001 г. в ЕС заговорили о необходимости интегрировать (непосредственно сцепить между собой) политику развития с политикой безопасности (об этом свидетельствует Гётеборгская программа 2001 г. по предупреждению острых конфликтов ${ }^{150}$ ) - в дальнейшем эта проблема получила в ЕС наименование security-development nexus ${ }^{151}$. Сложность такой интеграции связана с тем, что вопросы, относящиеся к сфере международного развития, в ЕС подлежат решению согласно обычной законодательной процедуре (это сфера совместного решения Европейского парламента и Совета, действующего квалифицированным большинством), тогда как по вопросам безопасности, по общему правилу, решения единогласно принимают Европейский совет и Совет. Эта разница, заложенная в Договоре, мешает проявиться взаимодополняемости и частичному совпадению двух политических полей (в вопросах нераспространения оружия массового поражения, предотвращения конфликтов, гражданского урегулирования кризисов, поддержки верховенства права).

Вопрос о применении кондициональности в сфере политики развития до сих пор является предметом разногласий между государствами-членами. Так, Бельгия в 2014 г. отказала Руанде в дополнительной выплате 40 млн. евро помощи из-за невыполнения последней условий по обеспечению свободы средств массовой информации и должного управления, а также политической транспарентности. Но в других европейских странах, в особенности во Франции, подробные жесты считают контрпродуктивными ${ }^{152}$. По мнению французских представителей, от них напрямую страдают наиболее уязвимые группы населения, а вовсе не правительство, нарушающее права человека либо демократические требования.

В Евросоюзе сейчас многие согласны с тем, что традиционная (бескорыстная) политика помощи устарела. Ведь асимметрия в отношениях между Европой и АКТ порождает дисбалансы, непосредственно сказывающиеся на европейской безопасности, в особенности в силу наблюдаемого растущего миграционного давления на Европу. Следовательно, сотрудничая с этими странами и предоставляя им помощь, Европа, которая испытывает сочетание угроз безопасности со стороны стран более бедных и экономический вызов со стороны растущих рынков, должна сегодня больше заботиться о продвижении в отношениях с ними собственных интересов безопасности и принципов своей внешней политики.

\footnotetext{
${ }^{149}$ Ganzle S. Coping with the 'Security-Development Nexus': The European Community's Instrument for Stability Rationale and Potential. German Development Institute, 2009. P. 52-55.

${ }^{150}$ О Гётеборгской программе подробнее см.: Schunnemann Julia. EU conflict prevention 10 years after Göteborg: Front-runner or lame duck? 10 years from the EU Programme for Conflict prevention // Policy Paper of the Institut Catalana Internacional per la Pau. June 2011. № 01. URL: https://www.academia.edu/1406975/EU_conflict_prevention_10_years_after_G\%C3\%B6teborg_Frontrunner_or_lame_duck_10_years_on_from_the_UE_Programme_for_Conflict_Prevention.

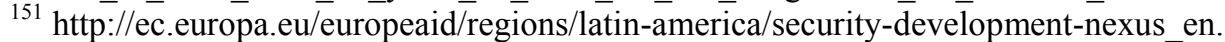

$152 \mathrm{http} / /$ www.euractiv.fr/section/aide-au-developpement/news/l-ue-divisee-sur-1-octroi-d-aide-au-developpement-enfonction-des-droits-de-l-homme/
} 
Таким образом, цели и принципы более современной политики развития ЕС были сформулированы в начале 2000-х годов. В основу политики развития Евросоюза теперь был положен дискурс о моральной ответственности и солидарности, в эпицентре которого - идея нормативной или этической власти, способной не только служить положительным примером для других, но и брать на себя инициативу в продвижении «глобальных публичных благ». Сквозной темой в этом смысле являются сокращение бедности и социальные вопросы. Иными словами, сам Евросоюз видит себя защитником интересов мировой бедноты. Комиссия играет здесь главную роль. Она не только направляет прямую донорскую помощь ЕС странам-реципиентам (в форме грантов, ссуд или инвестиций), но и занимается координацией политики развития государств-членов, чему способствуют делегации Евросоюза на местах. Координация и взаимная дополняемость курсов политики развития самого ЕС и отдельных входящих в Союз стран тем более важны ввиду большого объёма задействованных ресурсов.

Получателем донорской помощи от ЕС является, в частности, Беларусь. Так, в 20062011 гг. эта страна получила от ЕС и его государств-членов 493 млн. долл., что составило $72 \%$ от всей донорской помощи Беларуси. Для сравнения: за тот же период США предоставили Беларуси 104 млн. долл. помощи, или 15\% от её общего объёма ${ }^{153}$

ЕС предоставляет помощь развитию около 150 стран мира. Но в последние годы в некоторых развивающихся странах наблюдался заметный экономический рост, и им удалось улучшить ситуацию в том, что касается сокращения бедности. Поэтому, начиная с 2014 г., ЕС проводит поэтапное сокращение помощи таким странам, как Индия и Малайзия, а также многие страны в Латинской Америке, в большей мере сосредоточиваясь на беднейших регионах мира. В 2013 г. Евросоюз и его государства-члены потратили на цели развития 56.5 млрд. евро (более половины «официальной помощи развитию» по классификации ОЭСР), что составляет 0.43\% совокупного ВНД стран Евросоюза. Напомним, что в 2005 г. государства-члены ЕС обещали довести соответствующую цифру до $0.7 \%$ в 2015 г., но глобальный кризис помешал исполнению обещанного в полном объёме, хотя четыре страны EC (Великобритания, Дания, Люксембург и Швеция) уже преодолели эту планку. Сумма, выделенная на цели международного развития непосредственно из бюджета ЕС в 2013 г., составила 14.86 млрд. Помощь развитию пользуется стабильно высокой поддержкой европейских граждан (85\% опрощенных по данным Евробарометра $\left.{ }^{154}\right)$.

Решения о том, следует ли при этом инвестировать средства в здравоохранение, школьное образование или строительство дорог, принимаются в тесном сотрудничестве между ЕС и правительством страны-реципиента, которое также зачастую само управляет соответствующими программами и проектами. При подготовке программ в обсуждение вовлекаются организации гражданского общества соответствующих третьих стран.

ЕС является одним из самых влиятельных доноров в сфере содействия международному развитию $^{155}$. Но в последнее время ему всё более активно бросают вызов новые доноры, демонстрирующие иные модели помощи, предоставляемой на те же цели. Меняются потребности и запросы стран-получателей такой помощи, происходят и касающиеся данной сферы институциональные изменения внутри самого ЕС ${ }^{156}$. Сегодня на мировой арене с новой силой возрождаются геополитика и геоэкономика. Растущие интерес,

\footnotetext{
153 Подробно см.: Shyla K., Yahorau A. Civil society's role and place in the system of the EU's donor assistance for Belarus // Working paper. Center for European Transformation, 2013. http://cet.eurobelarus.info/files/File/AidAssistance-WD_EN.pdf.

$154 \mathrm{https} / /$ europa.eu/eyd2015/en/content/eu-development-aid.

155 В 2013 г. из европейских фондов и национальных бюджетов стран ЕС на помощь развитию было выделено в совокупности 56.2 млрд. евро.

${ }^{156}$ Michael Smith Foreign policy and development in the post-Lisbon European Union // Cambridge Review of International Affairs. 2013. Vol. 26, No. 3. P. 519-535.
} 
в особенности к странам Африки, со стороны США, Китая и других держав, может провоцировать соперничество между донорами.

Институциональное устройство ЕС очень серьёзно сказывается на том, что доступно Евросоюзу в плане его международных отношений. В сфере политики развития ситуация складывается таким образом, что ЕСВД формирует политический курс, тогда как Комиссия реализует этот курс на практике. Новые государства-члены пока не готовы вносить в неё свой равноценный вклад, а те страны ЕС, у кого своя развитая политика помощи, не горят желанием отказываться от неё в пользу общего подхода. В какой-то мере цели Евросоюза в данном отношении заданы внешними институциональными рамками - такими, как, например, Цели развития тысячелетия, которых государства-члены ООН и целый ряд международных организаций договорились достичь к 2015 г. ${ }^{157}$

В отличие от общей торговой политики, в данном случае речь идёт о сфере смешанной компетенции ЕС и государств-членов. Европейская помощь международному развитию формально подчинённая действию принципов взаимодополняемости (финансовых усилий ЕС и государств-членов), координации (согласования их программ помощи) и согласованности (учёта потребностей и интересов развивающихся стран в развитии глобальной экономики). С одной стороны, ЕС сам выступает донором по отношению к развивающимся странам. С другой стороны, он координирует усилия государств-членов, которые осуществляют помощь развивающимся странам самостоятельно ${ }^{158}$.

В статье 208 ДФЕС подтверждено, что сокращение и искоренение бедности - главная цель такого сотрудничества, что необходимо учитывать институтам ЕС при осуществлении тех направлений политики (миграционная, климатическая, гуманитарная помощь), которые в первую очередь способны воздействовать на развивающиеся страны. Но в то же время в политику развития ЕС инкорпорированы цели торговой либерализации и соображения безопасности (как известно, южные страны ЕС особенно озабочены проблемой миграции из Северной Африки).

Вопросы менеджмента переданы делегациям ЕС на местах. В рамках Комиссии в январе 2011 г. появился объединённый Генеральный директорат по развитию и сотрудничеству (DG DEVCO - EuropeAid), который впоследствии разделил с ЕСВД, включившей в себя Генеральный департамент Комиссии по внешним сношениям ( $D G$ $R E L E X)$, обязанности по разработке финансовых программ (программированию). С 1 января 2015 г. действует реформированный Генеральный директорат по международному

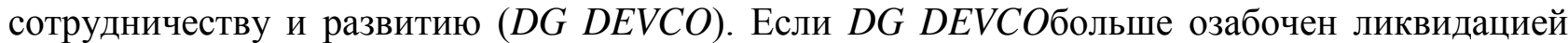
нищеты, то ЕСВД придерживается в целом более политизированного подхода, тогда как Генеральный директорат по торговле, отвечающий за связку между торговыми вопросами и помощью развитию, продвигает повестку торговой либерализации глобальных масштабов. Понятно, что подобные структурные особенности не способствуют согласованности общего курса ЕС в соответствующих вопросах.

Европейская комиссия совместно с ЕСВД осуществляют программирование, т.е. они вырабатывают и принимают решения, которые касаются приоритетов и объёмов финансирования по линии политики развития. ЕСВД лидирует в первых трёх фазах программирования: (1) распределение средств по странам; (2) подготовка стратегических докладов, касающихся каждой страны и каждого региона; (3) подготовка национальных и

\footnotetext{
1571 января 2016 г. вступили в силу 17 целей в области устойчивого развития (ЦУР), изложенные в Повестке дня в области устойчивого развития на период до 2030 года, которая была принята мировыми лидерами в сентябре 2015 года на саммите Организации Объединенных Наций. Евросоюз сыграл важную роль в её формировании. См.: http://ec.europa.eu/europeaid/policies/european-development-policy/2030-agenda-sustainabledevelopment_en.

${ }^{158}$ Подробнее см.: Dearden S. EU Development Policy: Delivering Aid Effectiveness // Jean Monnet/Robert Schuman Paper Series. 2008. Vol. 8, № 10. 8 p. URL: http://aei.pitt.edu/9008/1/DeardenEUdevelopmentLong08edi.pdf.
} 
региональных индикативных программ, которые затем поступают к Верховному представителю и члену Комиссии по международному сотрудничеству и развитию и должны получить одобрение коллегии ЕК в целом. После этого к своим обязанностям приступает Генеральный директорат по развитию, отвечающий за следующие две фазы программирования: (4) выработку ежегодных планов действий и (5) выполнение программ. Член Комиссии по развитию (в настоящее время эту позицию занимает Невен Мимица) контролирует весь цикл программирования. Европарламент голосует по вопросам финансирования политики развития из бюджета ЕС и поддерживает постоянный контакт с членом Комиссии по развитию.

Помимо прочего, Комиссия заявила о намерении использовать положительный опыт Европейского фонда стратегических инвестиций(ЕФСИ -European Fund for Strategic Investments)- финансового инструмента инвестиционного плана Юнкера ${ }^{159}$, чтобы создавать в будущем дополнительные условия для частных инвестиций в развивающихся странах (Комиссия предлагает принять Европейский план внешних инвестиций и учредить Европейский фонд устойчивого развития, чтобы мобилизовать, при условии участия в реализации плана государств-членов ЕС, до 88 млрд. евро публичных и частных средств для инвестирования как в Африке, так и в странах европейского соседства ${ }^{160}$ ).

В обмен на финансовые поступления в страны Африки ЕС ожидает от государствполучателей финансовой помощи большего содействия в разрешении миграционного кризиса, переживаемого Европой, в том числе реадмиссии граждан, которые проникают в ЕС нелегально, даже при отсутствии у ЕС официальных соглашений с этими странами о реадмиссии. Последнее вызывает сомнения у ряда депутатов Европарламента, которые усматривают в таких договорённостях опасность нарушения прав мигрантов ${ }^{161}$.

Среди представителей различных теоретических подходов отсутствует единство в оценке политики развития ЕС. В области теории международных отношений спорят между собой представители школы реализма, которые утверждают, что помощь третьим странам используется главным образом для продвижения политических и экономических интересов доноров, и либеральная школа, приверженцы которой признают полезность такой помощи для её получателей, которые могут использовать эти средства на цели модернизации. В области европейских исследований спор ведётся между сторонниками межправительственного/транснационального подхода, для которых ключевыми акторами выступают государства, и наднационального. Последние уверяют, что в политике развития ЕС главная роль принадлежит ЕК. Для приверженцев транснационализма, в свою очередь, эта политика представляет собой результат альянса, сложившегося между ЕК, некоторыми государствами-членами и международными организациями.

Среди государств-членов тоже отсутствует единство мнений в рассматриваемых вопросах. Но мы можем выделить три основные группы. Во-первых, это государства-члены из Северной Европы, имеющие собственные позитивные результаты в плане помощи третьим странам. Они предоставляют большие объёмы помощи бедным странам, ориентируясь главным образом на демократические правительства (за период с 1989 по 2008 годов количество демократических режимов в странах Африки к югу от Сахары выросло с 3 до 23), и при этом не являются энтузиастами дальнейшего углубления интеграции (в том числе более сплочённой общей внешней политики) в самом ЕС.

\footnotetext{
159 Подробно см.: Стрежнева М.В. Европейский союз: Инвестиционный план Жан-Клода Юнкера / М.В. Стрежнева // Год планеть:: экономика, политика, безопасность. Ежегодник. - Выпуск 2015 г. - С. $220-231$.

160 European Commission. State of the Union 2016: EU External Investment Plan. URL: https://eeas.europa.eu/sites/eeas/files/state_of_the_union_2016_external_investment_plan_factsheet.pdf.

${ }^{161}$ Потёмкина Ольга. «Новое партнёрство» Комиссии ЕС- - «амбициозный план» с неясными перспективами. Аналитическая записка №31 Института Европы PAH, 2016 (№61). C. 3-4. URL: http://instituteofeurope.ru/images/uploads/analitika/an61.pdf.
} 
Противоположность этой группе составляют южные и восточные государства-члены, которые не отличаются аналогичными высокими показателями, предоставляют помощь более состоятельным развивающимся странам с относительно недемократическими правительствами, но выступают большими энтузиастами в отношении дальнейшей европейской интеграции.

Наконец, две крупнейшие страны ЕС, считающиеся локомотивами интеграционного развития в Европе, отличаются в этом плане своей спецификой каждая. Так, объёмы французской помощи развитию не назовёшь стабильными. Она предоставляется в основном бывшим французским колониям с относительно недемократичными правительствами. Германская помощь в принципе невелика, особенно если брать в расчёт экономические возможности ФРГ, и при этом помощь странам с низким уровнем дохода не является для Берлина особым приоритетом, однако следует подчеркнуть высокую эффективность немецкого курса в достижении тех целей, которые он для себя при этом ставит (главная из них - содействие экспорту самой Германии ${ }^{162}$ ). Великобритания, в отличие от Германии и Франции, традиционно подчёркивала своё отрицательное отношение к укреплению собственной роли ЕС в международной политике и развитии, отстаивая свою особость и в этом вопросе. В 2000 г. британские представители даже называли европейскую политику помощи развитию «самой никчёмной в мире» ${ }^{163}$. В 2015 г. сам Лондон предоставил на цели развития более чем 100 развивающихся стран около 12 млрд. фунтов стерлингов $(0.7 \%$ своего ВНП $\left.{ }^{164}\right)$. Крупнейшим реципиентом британской помощи является Пакистан. Из указанной суммы только 1.5. млрд. распространялись по каналам ЕС. Принято считать, что британская политика помощи развитию отличается высоким качеством.

Главная ценность политики развития для самого ЕС состоит не в том, что она обеспечивает ему глобальное присутствие, а в том, что Евросоюз способен эффективно скоординировать и обеспечить разделение труда в этой области между государствамичленами. С окончанием холодной войны главный стратегический мотив для оказания помощи развивающимся странам утратил прежнее значение. Общества европейских стран стали с большим пристрастием относиться к соответствующим решениям своих правительств. Нарастает и критика многосторонних институтов со стороны НПО (она касается неолиберальной повестки и непрозрачного управления политикой помощи). Доноры стараются противопоставить этому большую открытость своих действий и более откровенно увязывают помощь со своими подразумеваемыми интересами (в сферах торговли, инвестиций и миграции).

\footnotetext{
162 По имеющимся подсчётам, каждый евро, потраченный Германией на помощь развитию в третьих странах, добавляет 1.8 евро к германским экспортным доходам. Помощь развитию в целом рассматривается в Берлине как важное средство для создания новых рабочих мест в Германии. См.: http://www.new-yorkun.diplo.de/contentblob/3099068/Daten/1194490/110322_German_Development_Policy_at_a_glance.pdf.

file://C:/Documents\%20and $\% 20$ Settings/strezhneva/\%D0\%9C $\% \mathrm{D} 0 \% \mathrm{BE} \% \mathrm{D} 0 \% \mathrm{~B} 8 \% 20 \% \mathrm{D} 0 \% \mathrm{~B} 4 \% \mathrm{D} 0 \% \mathrm{BE} \% \mathrm{D} 0 \% \mathrm{BA}$ $\% \mathrm{D} 1 \% 83 \% \mathrm{D} 0 \% \mathrm{BC} \% \mathrm{D} 0 \% \mathrm{~B} 5 \% \mathrm{D} 0 \% \mathrm{BD} \% \mathrm{D} 1 \% 82 \% \mathrm{D} 1 \% 8 \mathrm{~B} /$ Downloads/Szent-Ivanyi,\%20Balazs $\% 20$ -

\%20Brexit\%20What\%20impact\%20on\%20UK\%20and\%20EU\%20development\%20policy.pdf.

${ }^{164}$ Более $0.7 \%$ ВНП на цели мирового развития выделяют такие страны ЕС, как Швеция, Люксембург, Дания и Нидерланды (в порядке убывания).
} 


\section{§ 3.3 ГУМАНИТАРНАЯ ПОМОЩЬ}

Главный вызов политике гуманитарной помощи, которой Евросоюз занимается с 1992 г., составляет нехватка средств (при том, что гуманитарная помощь предоставляется в растущих объёмах). Ежегодный бюджет европейских институтов на соответствующие операции составляет свыше 1 млрд. евро. Как показывает диаграмма 3-1, вклады Евросоюза и государств-членов, взятые вместе, выводят ЕС на первое место в мире по объёму оказываемой им третьим странам гуманитарной помощи. Её распределением занимаются непосредственно ЕК либо (опосредованно) международные организации, включая агентства ООН. Средства по этой линии не предоставляются правительствам третьих стран. Чтобы быстро реагировать на внезапно возникшие гуманитарные кризисы, в ЕС выработаны процедуры для оперативного принятия финансовых решений в течение максимум трёх дней в наиболее острых случаях.

Гуманитарная помощь Евросоюза имеет широкий географический охват ${ }^{165}$. Два относительно недавних примера - это помощь в преодолении последствий землетрясения в Непале в 2015 г. $^{166}$ и связанный с конфликтом в Украине гуманитарный кризис. Акцент в принципе сделан на чрезвычайных ситуациях и «забытых кризисах» - тех местах, где есть большая нужда в гуманитарной помощи, но от других доноров она уже не поступает. Речь может идти о помощи продовольствием, чистой водой, дезинфекции и помощи с обеспечением гигиены ${ }^{167}$, помощи по линии здравоохранения ${ }^{168}$. В Сирии и Ираке в настоящее время ЕС оказывает гуманитарную помощь, которая увязана с попытками поставить под контроль миграцию (поток беженцев) из этих стран в Европу.

Генеральный директорат Комиссии по гражданской обороне и гуманитарной помощи (Directorate-General for European Civil Protection and Humanitarian Aid Operations - DG $E C H O)$ находится, естественно, в Брюсселе, но оснащён глобальной сетью из 48 отделений на местах (региональных - сразу для нескольких стран, национальных и субнациональных). Они размещены более чем в 40 странах. 12 региональных офисов (в Алма-Ате, Аммане, Каире, Боготе, Манагуа, Дакаре, Киншасе, Найроби, Яунде, Бангкоке, Исламабаде и Нью Дели) оказывают техническую и административную поддержку прочим, более мелким, отделениям в своём регионе.

\footnotetext{
165 http://ec.europa.eu/echo/factsheets_en.

${ }^{166}$ Для преодоления последствий землетрясения в Непале Евросоюз выделил 12 млн. евро. Уже через несколько часов после начала землетрясения на месте высадились направленные туда Комиссией эксперты по гуманитарной помощи и гражданской обороне. Был задействован Механизм по гражданской обороне, что помогло скоординировать помощь по двум направлениям (доставка технического оборудования и заброска поисковых и спасательных команд). См.: European Commission. Nepal Earthquake Factsheet, June 2015. http://ec.europa.eu/echo/files/aid/countries/factsheets/nepal_earthquake_en.pdf.

${ }^{167} \mathrm{http} / / /$ ec.europa.eu/echo/files/aid/countries/factsheets/thematic/wash_en.pdf.

168 ЕК ежегодно выделяет около 200 млн. евро в поддержку гуманитарных программ по здравоохранению. По этой линии было оказана прямая помощь мерам по сдерживанию распространения вируса Эбола в Западной Африке и вакцинации против полиомиелита в Украине. URL: http:/ec.europa.eu/echo/what/humanitarianaid/health_en.
} 


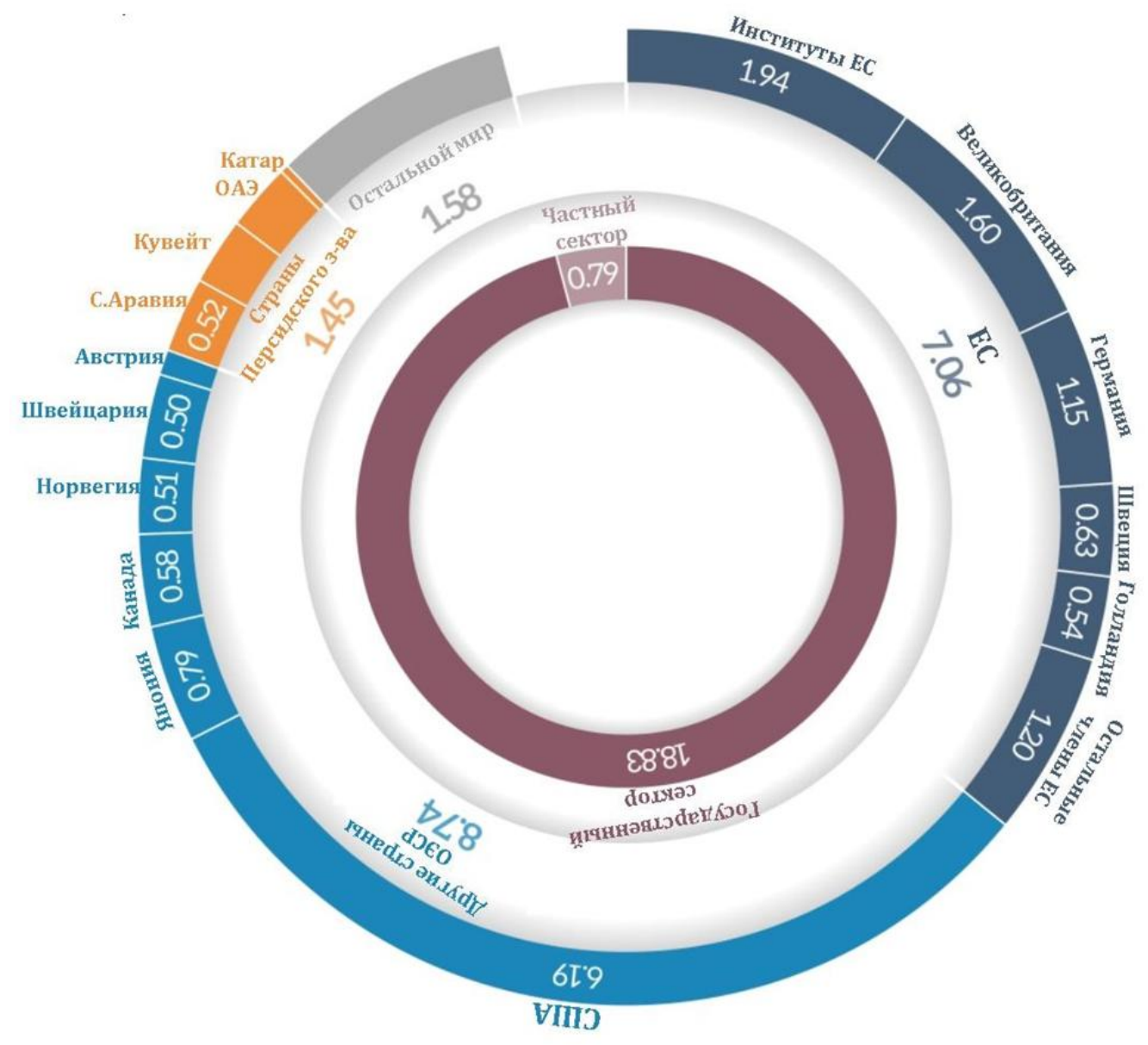

Диаграмма 3-1. Доноры гуманитарной помощи и их вклады в 2015 г. (в миллиардах долларов США)

Источник: Dobreva Alina and Latek Marta. Funding gap: A challenge for the World Humanitarian Summit (WHS) // EP Briefing: European Parliamentary Research Service. May $2016^{169}$.

Особый Механизм ЕС по гражданской обороне был создан в 2001 г., чтобы укрепить сотрудничество между соответствующими национальными органами. В настоящее время в нём участвуют все 28 стран ЕС, а также Исландия, Черногория, Норвегия, Сербия и Бывшая Югославская Республика Македония (БЮРМ). Механизм обеспечивает более оперативный и действенный ответ на чрезвычайные ситуации, координируя доставку бригад по гражданской обороне в пострадавшую страну (за такой помощью к ЕС может обратиться любая страна мира, за годы существования Механизма было получено более 200 таких запросов). Его действия, помимо прочего, распространялись на преодоление последствий тайфуна на Филиппинах (2013 г.) и наводнения в Сербии и Боснии и Герцеговине (2014 г.), вспышки лихорадки Эбола (2014 г.) и на урегулирование кризиса с беженцами на территории Европы (2015 г.).Операционным центром Механизма по гражданской обороне выступает Координационный центр по преодолению чрезвычайных ситуаций (Emergency Response Coordination Centre-ERCC).

Предоставление гуманитарной помощи относится к совместной компетенции Евросоюза и государств-членов. Правовую основу для собственно европейской

${ }^{169} \mathrm{http}: / /$ www.europarl.europa.eu/RegData/etudes/BRIE/2016/582030/EPRS_BRI(2016)582030_EN.pdf. 
гуманитарной помощи обеспечивает статья 214 ДФЕС. Согласно этой статье, Европарламент и Совет определяют рамки, в которых такая гуманитарная помощь осуществляется. В 2007 г. главы Совета, Парламента и Комиссии подписали документ о европейском консенсусе в вопросах гуманитарной помощи ${ }^{170}$. Онобеспечилболее тесное институциональное сотрудничество и последовательность в оказании помощи, подтверждая лидерство Комиссии в вопросах координации. Комиссия также отвечает за представительство ЕС на международных площадках в тех случаях, когда речь идёт о вопросах гуманитарной помощи.

В 2015 г. цели расходования средств по этой линии были определены Комиссией следующим образом ${ }^{171}$ :

1. оказывать гуманитарную и продовольственную помощь, улучшать состояние дел и предоставлять защиту подверженному опасности населению, затронутому техногенными кризисами;

2. оказывать гуманитарную и продовольственную помощь, улучшать состояние дел и предоставлять защиту подверженному опасности населению, затронутому природными катастрофами;

3. оказывать гуманитарную поддержку для повышения готовности населения к противостоянию катастрофам;

4. поддерживать стратегии, позволяющие местным сообществам и институтам лучше подготовиться к природным катастрофам, смягчать их последствия и противостоять им (Южная Азия, Тихий океан, Карибский бассейн и Южная Америка);

5. совершенствовать способы доставки помощи посредством дополнительных и тематических действий, направленных на повышение эффективности, качества, своевременности гуманитарных акций и осведомлённости о них местного населения.

Европейский союз (сам Союз и его государства-члены в совокупности) выделяют самые большие объёмы финансирования на гуманитарные цели в мире. Бюджетная позиция «Глобальная Европа» позволяет оказывать срочную помощь из бюджета ЕС вне территории ЕС в случаях природных и техногенных катастроф. На эти цели выделяется всего $0.61 \%$ от общей суммы расходов в рамках Многолетней финансовой перспективы 2014-2020 гг., что, тем не менее, составляет в сумме внушительные 6621.70 млн. евро на весь период. Потребность в гуманитарной помощи трудно предсказывать заранее, а потому согласованные годовые цифры могут меняться при необходимости. Кроме этого, предусмотрен Резерв ЕС для экстренной помощи (EU Emergency Aid Reserve), который является частью «Гибких и специальных инструментов» (Flexibility and Special Instruments). Он позволяет выделить ещё 280 млн. евро в год, чтобы отреагировать на неожиданные события и серьёзные кризисы вне территории ЕС - такие, как конфликты в Сирии и в Мали или засуха в Сахеле.

Дополнительной инициативой $\mathrm{EC}$ в сфере гуманитарной помощи является Европейский добровольный корпус гуманитарной помощи (European Voluntary Humanitarian Aid Corps - EVHAC) , запущенный в 2011 г. Корпус координирует усилия добровольцев и организаций, в особенности молодёжи, из стран ЕС и из других стран. На 2014-2020 гг. на его деятельность из бюджета ЕС выделено 148 млн. евро. Данная инициатива поддерживает НПО и международные организации, активные в области гуманитарной помощи и снижения

${ }^{170} \mathrm{http}: / /$ ec.europa.eu/echo/files/media/publications/consensus_en.pdf.

171 European Commission. Commission Implementing Decision of 15.6.2015, amending Commission Implementing Decision C (2014) 10012 of 5.1.2015 on the financing of humanitarian aid operational priorities from the 2015 general budget of the European Union. http://ec.europa.eu/echo/files/funding/decisions/2015/worldwide_01000_mod_en.pdf/ 
риска катастроф. Такие НПО должны формировать партнёрства и предлагать проекты,

Таблица 3-1

Бюджетные ассигнования на гуманитарную помощь (на определенные цели) в 2015 г.

\begin{tabular}{|c|c|c|}
\hline Цели & \begin{tabular}{l}
\multicolumn{2}{l}{ Изначально } \\
выделенные средства (в \\
млн. евро)
\end{tabular} & Окончательная сумма \\
\hline $\begin{array}{l}\text { Техногенные } \\
\text { катастрофы }\end{array}$ & 477.6 & 573.6 \\
\hline Природные катастрофы & 138.6 & 174.3 \\
\hline $\begin{array}{c}\text { Готовность к } \\
\text { преодолению кризиса } \\
\end{array}$ & 9 & 9 \\
\hline \begin{tabular}{l}
\multicolumn{1}{c}{ Способность } \\
справиться с кризисом (для \\
Южной Азии, Тихого \\
океана, Карибского \\
бассейна и Южной \\
Америки) \\
\end{tabular} & 37.3 & 37.3 \\
\hline Доставка помощи & 36.9 & 43.3 \\
\hline Всего & 699.4 & 837.5 \\
\hline
\end{tabular}

Источник: Commission Implementing Decision of 15.6.2015, Annex II.

умножающие их собственные возможности в указанных областях, чтобы получить европейское финансирование, и направлять европейских волонтёров в поддержку гуманитарных операций по всему миру (за пределами ЕC) ${ }^{172}$.

С 2013 г. Европейская комиссия может использовать также новый инструмент трастовых фондов ЕС (в случае чрезвычайных ситуаций и для помощи в преодолении их последствий $)^{173}$. Это фонды, финансируемые одновременно из многих источников, однако большая часть средств опять-таки исходит из бюджета ЕС и/или из Европейского фонда развития. К числу первых трастовых фондов, созданных в 2014 г., относятся фонд Bêkou (108 млн. евро) на цели стабилизации и восстановления в Центральноафриканской Республике и фонд Madad (542 млн. евро) для Сирии. В 2015 г. Евросоюзомбыл создал крупнейший на сегодняшний день трастовый фонд в 1,8 млрд. евродля решения миграционных проблем в Африке. Он оказывает помощь африканским странам в урегулировании миграционного кризиса) ${ }^{174}$. Фонд призван служить для помощи в регионе Сахеля, в бассейне озера Чад, на Африканском Роге и в Северной Африке (через эти регионы проходят главные африканские миграционные пути в Европу). Фонд обеспечен финансовыми инструментами Европейского союза, а также вкладами государств-членов ЕС и других доноров (например, Норвегия и Швейцария), которые, впрочем, сравнительно

$172 \mathrm{http}: / /$ www.europarl.europa.eu/RegData/etudes/BRIE/2016/582030/EPRS_BRI(2016)582030_EN.pdf.

173 EU Trust Funds for external action. First uses of a new tool. http://www.europarl.europa.eu/RegData/etudes/BRIE/2015/572797/EPRS_BRI\%282015\%29572797_EN.pdf.

${ }^{174} \mathrm{http}: / /$ www.interfax.ru/world/478862 
невелики. Аналитики усматривают в подобных трастовых фондах некую промежуточную категорию между помощью двусторонней и многосторонней ${ }^{175}$.

Поскольку реагирование на чрезвычайные ситуации первостепенной значимости требует быстрых финансовых решений, соответствующие процедуры предусматривают трёхдневный срок для принятия решения, трёхмесячный срок имплементации и денежный лимит в 3 млн. евро. Согласно классификации $\mathrm{OOH}$, в настоящее время к чрезвычайным гуманитарным ситуациям третьего уровня (наиболее экстренным) отнесены, исходя из их масштаба и сложности, ситуации в Сирии, Южном Судане, Ираке и Йемене. Другие чрезвычайные ситуации, связанные с новыми и уже существующими гуманитарными кризисами, которые не требуют столь же быстрой реакции, финансируются в полугодовой срок и не имеют ограничений по объёму выделяемых при этом средств (объём определяется исходя из потребности).

Важным географическим направлением для гуманитарной помощи Евросоюза с 1990-х годов являлась Центральная Азия, где она в основном сосредоточена на Кыргызстане и Таджикистане. Её ключевую организационную структуру в данном регионе составляет программа глобального охвата по обеспечению готовности к чрезвычайным ситуациям (Disaster Preparedness - DIPECHO ${ }^{176}$ ), запущенная в 1998 г., которая призвана снижать риски катастроф и их последствия. Центральная Азия, как и Южный Кавказ, были включены в неё в 2003 г. Впрочем, у этой программы немного собственных проектов. В основном она опирается на сотрудничество с разными НПО, с ООН и связанными с ООН организациями, которые выступают в роли «подрядчиков».

Но в том же регионе работают сейчас и другие доноры, в том числе из стран, не входящих в ОЭСР, включая Казахстан, который в 2000-2012 гг. потратил на гуманитарную помощь 63.6 млн. долларов США, из которых треть была израсходована именно в других странах Центральной Азии.

Кроме того, на низовом уровне (особенно в Таджикистане, Кыргызстане и Узбекистане) важным источником поступления средств, превосходящим по значимости иностранную помощь, стали денежные переводы туда трудовых мигрантов (прежде всего тех, кто работает в России). Они обеспечивают относительно более высокую экономическую и социальную устойчивость местных сообществ к катастрофам и потрясениям по сравнению с ситуацией $1990-$ х годов ${ }^{177}$.

Средства, выделенные на гуманитарные цели, как уже сказано, не попадают непосредственно в руки соответствующих правительств. Они поступают к партнёрским организациям Евросоюза по оказанию помощи (это специализированные агентства государств - членов ЕС, агентства ООН, международные организации и НПО).

\footnotetext{
${ }^{175}$ Reinsberg B., Michaelowa K, Eichenauer V. Z. The rise of multi-bi aid and the proliferation of trust funds, 2015. URL: http://www.ipz.uzh.ch/forschung/lehrstuehle/ep/research/internationaldevelopment/multi-bi-aid/A1_9apr15.pdf.

${ }^{176}$ Humanitarian Aid and Civil Protection/ URL: http://ec.europa.eu/echo/what/humanitarian-aid/risk-reduction_en. CM. также: European Commission. Disaster Preparedness Programme: DIPECHO. URL: http://ec.europa.eu/echo/files/policies/dipecho/presentations/programme_overview_11_07_en.pdf

177 De Cordier Bruno. The EU's humanitarian aid and civil protection policy in Central Asia: Past crises and emergencies to come // EUCAM Policy Brief, № 29, January $2013 . \quad$ URL: http://www.eucentralasia.eu/uploads/tx_icticontent/EUCAM-PB-29-EN-EU-Humanitarian-Aid.pdf.
} 


\section{§ 3.4 ЕВРОПЕЙСКАЯ ПОЛИТИКА СОСЕДСТВА}

Европейская политика соседства действует с мая 2004 г. ${ }^{178}$. Её запуск был связан с процессом массированного расширения ЕС в 2000-х годах, сопровождавшимся серьёзным изменением его внешних границ, что создавало проблему выстраивания отношений Евросоюза со странами нового соседства. По выражению Карела де Гюхта, в то время министра иностранных дел Бельгии, Евросоюз уже достиг пределов в своей способности «усваивать новые страны-члены» ${ }^{179}$.В контексте нарастающей усталости европейцев от быстрого роста интеграционного объединения вширь ${ }^{180}$ (enlargement fatigue ${ }^{181}$ ) ЕПС преследовала цель в краткосрочной и среднесрочной перспективе положить предел дальнейшему расширению ЕС, но при этом продолжить распространение вовне европейских ценностей демократии, уважения прав человека и рыночной экономики с тем, чтобы пограничные с ЕС страны не создавали для него угроз, способных прямо или косвенно нарушить мир в единой Европе (как максимум) или помещать ему в реализации его собственных стратегических целей и задач (как минимум).

Отметим, что само название данной политики с приставкой «европейская» в англоязычном варианте (European Neighbourhood Policy) выглядит нарочитой попыткой ЕС присвоить «марку» принадлежности к Европе прежде всего себе, что противоречит концепции Совета Европы, все члены которого, в том числе и не входящие в ЕС, являются европейскими странами. При этом политика соседства не включает Россию (Россия в своё время отказалась присоединиться к данной инициативе, отдав предпочтение двустороннему формату отношений $\mathrm{c}$ ЕС). Политика соседства EC предусматривает упор на кондициональность, что не подходит России.

ЕПС была распространена на 6 восточных (Азербайджан, Армения, Беларусь, Грузия, Молдова, Украина) и 10 южных (Алжир, Египет, Израиль, Иордания, Ливан, Ливия, Марокко, Палестинская Автономия, Сирия, Тунис) по своему месторасположению относительно Евросоюза стран, определяемых в качестве его «соседей». Не все из них граничат с ЕС территориально (по морю или по суше) - так, Иордан и Азербайджан в географическом смысле непосредственными соседями ЕС не являются. В целом же, если не считать географической близости перечисленных стран к $\mathrm{EC}$, a также проблем с конфликтами, стабильностью и соблюдением прав человека, то в принципе у них мало общего. По состоянию на период завершения 2016 г. инструменты ЕПС действуют лишь в 12 перечисленных странах - переговоры с Алжиром пока не окончены, Беларусь, Ливия и Сирия остаются вне действия большинства инструментов ЕПС.

Официальный Брюссель приостановил сотрудничество с Минском после президентских выборов 2010 г. в Беларуси, которые были признаны в Европе недемократичными (оно стало частично восстанавливаться, начиная с 2014 г.). Ливия изначально не заключала соглашения об ассоциации с ЕС, но получала финансовую помощь в рамках тематических программ по поддержке гражданского населения. Отношения ЕС с

\footnotetext{
${ }^{178}$ Подробно см.: Poli Sara, ed. The European Neighbourhood Policy - Values and Principles. London and New York: Routledge, 2016.

179 Бельгия - против ускоренного вступления Грузии и Украины в ЕС и НАTO. 15 / 09 / 2008. URL: http://xn-80azep.xn--p1ai/ru/news/20080915/00356.html.

${ }^{180}$ По теме соотношения процессов расширения и углубления интеграции см.: Борко Ю.А. Взаимосвязь процессов расширения и углубления европейской интеграции; Россия - Европейский Союз: сценарии взаимоотношений // Расширение Европейского Союза и Россия. М., 2006.

${ }^{181}$ О феномене усталости от расширения см., например: Szołucha Anna. The EU and Enlargement Fatigue:

Why has the European Union not been able to counter enlargement fatigue? // Journal of Contemporary European Research. 2010. Volume 6, Issue 1. Available at: http://www.jcer.net/index.php/jcer/article/view/124/192.
} 
Дамаском были заморожены с 2011 г. из-за эскалации насилия режима Башара Асада против сирийского населения и многочисленных нарушений прав человека.

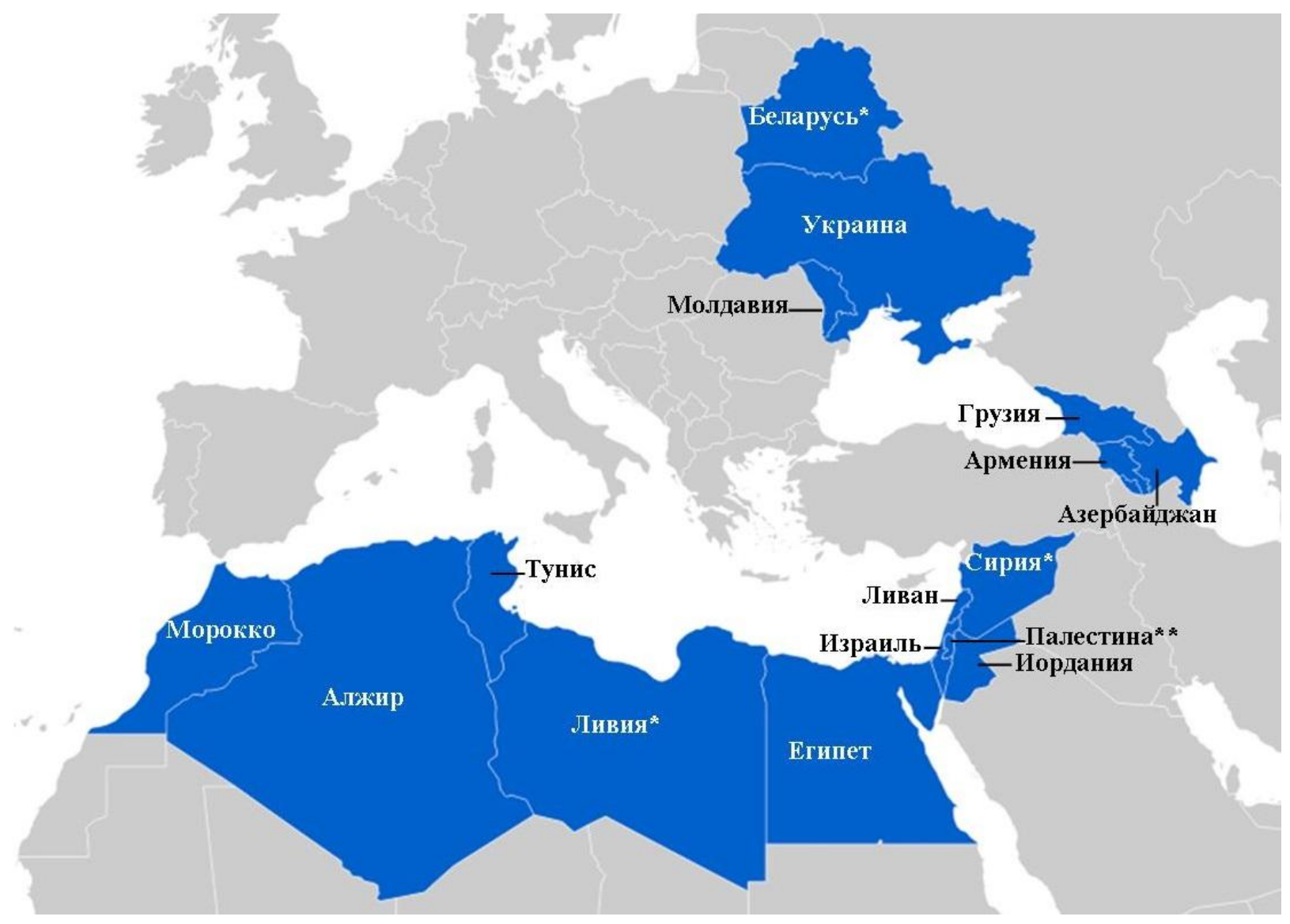

Рисунок 3-1. Страны-участницы Европейской политики соседства ${ }^{182}$

* Временно приостановлено.

** Упоминание Палестины не следует толковать как формальное признание Евросоюзом Государства Палестина.

В политике соседства используются следующие основные инструменты:

1) Евросоюз (и его государства-члены) заключают либо соглашения о партнерстве и сотрудничестве (СПС), либо соглашения об ассоциации (СА). В частности, в последние годы заключены Соглашения об ассоциации и создании углублённой и всеобъемлющей зоны свободной торговли с Грузией, Республикой Молдова и Украиной, ведутся переговоры по новому рамочному соглашению с Арменией и авторизовано со стороны ЕС начало переговоров по новому всеобъемлющему соглашению с Азербайджаном.

2) С 2014 г. ключевым инструментом по линии ЕПС является Европейский инструмент соседства (ЕИС) общим объемом 15,4 млрд. евро на период 2014-2020 гг. ЕИС поддерживает 4 вида программ: двусторонние программы для стран соседства, региональные программы для восточных и южных стран соседства, финансирование по линии программы «Эразмус для всех» и программы трансграничного сотрудничества между государствамичленами и странами соседства (на период до 2020 г. реализуется 16 программ приграничного сотрудничества, в 7 из которых предусмотрено участие России).

182 EUISS Yearbook of European Security. YES 2016 / Paris: European Union Institute for Security Studies, 2016. P. 24. 
3) Для каждой страны соседства разрабатываются стратегические доклады и планы действий (повестки дня ассоциации для стран Восточного партнёрства) с краткосрочными и среднесрочными приоритетами, отражающими потребности и возможности конкретно страны и интересы ЕС, на период от трёх до пяти лет. Ежегодно Комиссия совместно с Верховным представителем публикуют отчёт о прогрессе в достижении целей, зафиксированных в этих документах.

4) Стандартным внешнеполитическим инструментом в рамках Европейской политики соседства стали соглашения об облегчении визового режима и реадмиссии или о партнёрстве в вопросах мобильности. Соответствующие соглашения заключены с Украиной, Молдовой, Грузией, Арменией, Азербайджаном. С Беларусью в 2014 г. были начаты соответствующие переговоры.

5) Инструмент макрофинансовой помощи применяется ЕС в отношении стран, которые переживают кризис платёжного баланса. Помощь предоставляется в виде среднесрочных и долгосрочных займов, кредитов, грантов. Этот продвинутый инструмент был создан специально для стран, которые близки ЕС географически, экономически и/или политически. Не считая Украины, в разное время финансовую помощь от ЕС уже получили или получают до сих пор Тунис, Грузия, Армения, Молдавия, Киргизия и Иордания. Предварительным условием для получения макрофинансовой помощи является соблюдение прав человека, наличие действующей демократии, включая многопартийную парламентскую систему, верховенство права. При этом транши помощи строго увязаны с выполнением условий, направленных на усиление финансовой и макроэкономической стабильности в стране-реципиенте. Соответствующие условия зафиксированы в меморандумах о взаимопонимании между ЕС и конкретной третьей страной.

Речь, таким образом, идёт, прежде всего, об отношениях Евросоюза и его государствчленов с каждой отдельно взятой страной-партнёром в формате « $28+1 »(28$ стран ЕС +1 страна-партнёр). Эти «двусторонние» отношения дополнены региональными и многосторонними инициативами - Союз Средиземноморского партнёрства (ранее известный как Барселонский процесс) ${ }^{183}$, Восточное партнёрство ${ }^{184}$ и Синергия Чёрного моря ${ }^{185}$. Нельзя отрицать того, что столь сложная, запутанная конструкция, сама по себе, способна провоцировать некоторую неразбериху.

В то же время финансовые возможности ЕС в рамках этой политики невелики, хотя официальные представители Комиссии выражали надежду, что в 2016 г. удастся перераспределить в пользу ЕПС часть средств, выделяемых на внутренние нужды ЕС (по линии сельскохозяйственной политики и структурных фондов). Процедуры ведения переговоров, мониторинга и отчётности (со всеми их преимуществами и недостатками), практиковавшиеся в отношении стран-кандидатов на вступление в Евросоюз, впоследствии были навязаны и «соседям».

В рамках ЕПС Евросоюз предложил партнёрам привилегированные отношения (доступ на единый внутренний рынок и безвизовый режим), построенные на подразумеваемой приверженности общим ценностям. Уровень взаимоотношений поставлен в зависимость от того, в какой мере эти ценности разделяют обе стороны. По ожиданиям ЕС, приверженность демократии должна включать свободные и справедливые выборы, свободу волеизъявления, свободу собраний и объединений, независимость суда, борьбу с коррупцией

\footnotetext{
183 Трофимова О.Е. Эволючия средиземноморской политики Евросоюза: путь от сотрудничества к интеграциии. М.: ИМЭМО, 2011. 122 с.

${ }_{184}$ Восточное партнёрство до и после Вильнюса. Доклады Института Европы. М.: Институт Европы РАН, 2014. № $301.94 \mathrm{c}$.

185 Язькова А.А. Синергия Чёрного моря и «Восточное партнёрство» // Независимая газета. 15.06.2009. [Electronic resource]. - Mode of access: http://www.ng.ru/courier/2009-06-15/11_Sinergiya.html
} 
и демократический контроль над вооруженными силами. Евросоюз всегда подчёркивал роль гражданского общества в продвижении демократии.

Согласно избранному формату, финансовые средства по линии ЕПС расходуются на сотрудничество с 16 названными странами. Ключевым элементом управления в этом контексте выступают двусторонние планы действий в рамках ЕПС, формально являющиеся предметом взаимной договорённости между ЕС и каждой из стран в отдельности. В планах определена повестка политических и экономических реформ, установлены краткосрочные и среднесрочные приоритеты. В складывающемся таким образом «партнёрстве» Евросоюз, тем не менее, сохраняет главенствующую роль за собой, поддерживая асимметричную форму диалога $^{186}$. Отношения, таким образом, приобретают скорее иерархические черты, нежели горизонтальные, даже если «соседи» присоединяются к позиции ЕС добровольно.

Изначально ЕПС опиралась на институты, которые появились в рамках соглашений о партнёрстве и сотрудничестве Евросоюза с бывшими советскими республиками ещё в первой половине 1990-х годов (и на старые соглашения об ассоциации в случае стран Южного Средиземноморья), т.е. подход к институциональным аспектам данной политики был крайне консервативным. Лишь в порядке исключения и для решения особых задач в сфере обеспечения безопасности, причём первоначально на временной основе, создавались такие структуры, как Мониторинговая миссия Евросоюза в Грузии (создана в 2008 г. численностью в 200 человек первоначально на год, но с тех пор её мандат регулярно продлялся, за её работой надзирает Совет ЕС), Специальный представитель ЕС по разрешению конфликта в Приднестровье (А. Якобовиц де Сегед был назначен на этот пост в 2005 г.) или Консультативно-техническая Миссия ЕС по оказанию пограничной помощи Молдове и Украине (открыта в 2005 г., за работу миссии отвечает ЕК).

ЕПС иногда называют гибридной политикой, утверждая, что её трудно отнести к какой-то определённой категории ${ }^{187}$. Судя по набору инструментов, имеется явное сходство с процессом расширения $\mathrm{EC}^{188}$. В концептуальном плане её можно толковать как форму экстернализации (перенесения действия из внутреннего во внешний план). В основе применения ЕПС лежала уверенность Брюсселя, что если страна добилась вхождения в открытый и интегрированный рынок общеевропейского уровня, функционирующий на основе совместимых или гармонизированных правил, то она сблизилась с Евросоюзом в максимальной степени, доступной тем государствам, которые не являются его полными членами, и фактически сможет пользоваться подразумеваемыми преимуществами своего нового статуса, трактуемого как членство в ЕС без права голоса ${ }^{189}$. Речь первоначально шла о намерении перенести ценности и нормы Евросоюза на страны соседства, реализуемом в рамках общего процесса европеизации.

Хотя политическую обусловленность придумали не в ЕС, он прибегает к ней чаще других международных акторов. Кондициональность подразумевает увязывание ожидаемых выгод для другой стороны (в плане финансовой помощи, уступок в торговле, соглашений о

\footnotetext{
${ }^{186}$ Hettne B., Söderbaum F. Civilian Power or Soft Imperialism? EU as a Global Actor and the Role of Interregionalism // European Foreign Affairs Review. 2005. Vol. 10. № 4. P. 535-552.

187 Gaenzle S. Policy-making and New Modes of Governance in the European Neighborhood Policy // Jean Monnet/Robert Schuman Paper Series. 2008.Vol. 8 № 8.18 p.

${ }^{188}$ Tulmets E. Adapting the Experience of Enlargement to the Neighbourhood Policy: The ENP as a Substitute to Enlargement? / The EU and its Neighbourhood: Policies, Problems, Priorities/ Ed. by P. Kratochvíl. Prague: Institute of International Relations, 2006. P. 29-57.

${ }^{189}$ Meloni G. Is the same toolkit used during enlargement still applicable to the Countries of the New Neighbourhood? A problem of mismatching between objectives and instruments // Workshop paper. European University Institute, 2006. P. 10.
} 
сотрудничестве, политических контактов) с выполнением условий, касающихся защиты прав человека и продвижения демократии ${ }^{190}$.

В 1980-е гг. международные финансовые институты стали обставлять условиями, связанными с продвижением либеральных экономических реформ, предоставление ими отдельным странам макрофинансовой помощи. К 1990-м гг. у них сложилась практика увязывания такой помощи уже не только с требованиями по линии экономического управления, но и с политическими требованиями (исходя из того соображения, что эффективное использование такой помощи страной-реципиентом требует верховенства закона и укрепления институтов). Некоторые из стран ЕС (Великобритания, Германия, Голландия, Дания, Швеция) традиционно обусловливали свою помощь развивающимся странам политическими требованиями, исходя из этических соображений. Комиссия, со своей стороны, до 1990-х годов держалась технократической линии и избегала обусловленности в этом вопросе, но затем изменила свою позицию и стала проявлять более активную заботу о соблюдении в развивающихся странах прав человека.

Но наибольшую значимость кондициональность обрела в ходе расширения ЕС в 1990-2000-е годы ${ }^{191}$. В этом случае политическая трансформация в странах Центральной Европы была прямо увязана с перспективой присоединения к ЕС. Евросоюз установил принципы и критерии для оценки успехов соответствующих стран в политических и экономических реформах (копенгагенские критерии 1993 г.), ввёл методы «скрининга» складывающейся там ситуации, ежегодные отчёты по внедрению в этих странах законодательства ЕC (aquis communautaire), а также адресовал им руководящие указания, целевые ориентиры и приоритеты, которых они должны были придерживаться.

Политика Евросоюза по трансформации Центральной Европы через вхождение стран региона в состав ЕС, которая проводилась в 1990-2000-е годы, была впоследствии расценена как наиболее успешная часть его внешней политики, тогда как политическую обусловленность посчитали важным элементом такого успеха, от которого не следует отказываться и впредь ${ }^{192}$. В политике соседства большая часть инструментов была позаимствована именно из того арсенала, который сложился в процессе расширения ${ }^{193}$.

Однако, по мнению Аннализы Мелони, такой упор на политическую составляющую (кондициональность) в области ЕПС создавал больше проблем, нежели их решал ${ }^{194}$. Как справедливо замечает другой специалист - Роза Бальфур ${ }^{195}$, заимствование логики и инструментов расширения было произведено без учёта принципиальных различий между Центральной Европой и странами соседства:

1) отсутствия в последнем случае гарантированной перспективы присоединения к ЕС в качестве побуждения к соблюдению условий, выдвинутых ЕС;

2) отсутствия консенсуса по поводу необходимости «возращения в Европу»;

3) принципиально иного понимания суверенитета и допустимых пределов вмешательства во внутренние дела.

190 Smith K.E. The Use of Political Conditionality in the EU's Relations with Third Countries: How Effective? //European Foreign Affairs Review. 1998.Vol. 3. № 2. P. 253-274.

${ }^{191}$ Стрежнева М.В. Условия партнерства с Европейским союзом // Мировая экономика и международные отношения. 2007. № 6. С. 3-13.

192 Balfour R. EU Conditionality after the Arab Spring. 2012. [Electronic resource]. - Mode of access: http://www.epc.eu/documents/uploads/pub_2728_papersbalfour_for_euromesco16.pdf.

${ }^{193}$ Kelley J. New Wine in Old Wineskins: Promoting Political Reforms through the New European Neighbourhood Policy // Journal of Common Market Studies. 2006.Vol. 44.№ 1. P. 29-55.

${ }^{194}$ Meloni A. EU Visa Policy and Conditionality: A Two Way Road // Europe As A Global Actor. Conference Paper. 2016. [Electronic resource]. - Mode of access:http://cei.iscte-iul.pt/europeglobalactor/eu-visa-policy-andconditionality-a-two-way-road/

195 Balfour R. Ibid. P.14. 
Ввиду этого впоследствии Комиссия несколько смягчила собственную позицию, обратившись к идее «совладения» (joint ownership) политикой соседства и к формам взаимодействия с партнёрами, больше отражающим «горизонтальную, интерактивную, гибкую и инклюзивную структуру управления, которую часто называют «сетевым управлением» ${ }^{196}$. Она стала больше внимания уделять методу социализации. Было признано, что вопрос о приоритетах, как и о сроках достижения поставленных целей, отныне нужно решать во взаимодействии обеих сторон. Однако социализация способна принести осязаемые плоды только в длительной перспективе.

Соглашения об ассоциации или о партнёрстве, связавшие ЕС со странами соседства, непременно содержат пункт, который в принципе позволяет Евросоюзу прибегать к негативным мерам по отношению к странам-соседкам, начиная от временного прерывания помощи и до полного прекращения отношений, в случае нарушения последними фундаментальных принципов (хотя ЕС и не злоупотребляет такой возможностью). Слишком много внимания уделяется именно двусторонним отношениям, тогда как многие проблемы стран соседства требуют регионального подхода к их решению.

Кондициональность выступает как главное средство по достижению сближения с европейскими образцами в законодательстве, но неопределённость конечной цели в углублении сотрудничества (отсутствия для стран соседства чёткой перспективы последующего вхождения в ЕС) в данном случае подрывает эффективность его использования. Если в случае кандидатов на членство в ЕС такая цель вполне ясна, то страны-соседи находятся в принципиально иной ситуации.

На практике, скажем, кондициональность сильно поспособствовала стимулированию усердия Киева в проведении реформ (как минимум, в принятии национальных законов, регулирующих государственные закупки, и антикоррупционного законодательства) ${ }^{197}$. Официальный Брюссель, кроме того, дал понять, что выплаты Киеву по линии ЕПС будут задержаны в случае дальнейшего промедления с судебной реформой в Украине, и 2 июня 2016 г. украинский парламент (Верховная рада) окончательно утвердил закон, меняющий нормы Конституции Украины с целью оградить правосудие от политического воздействия. Впрочем, эксперты не выражают оптимизма по поводу внедрения этого и прочих новых законов в жизнь. Согласно официальным заявлениям ЕС, финансовая помощь будет увеличена только в случае явных доказательств борьбы с коррупцией в Украине ${ }^{198}$.

Первым и наиболее амбициозным из договоров нового поколения между ЕС и странами Восточного партнёрства стало Соглашение об ассоциации между ЕС и Украиной, подписанное 27 июня 2014 г. Оно было ратифицировано Верховной радой и Европейским парламентом 16 сентября 2014 г. и заменило ранее действовавшее Соглашение о партнерстве и сотрудничестве от 1998 г. Соглашение2014 г. задаёт новые рамки для двусторонних отношений Евросоюза с Украиной, устанавливая политическую ассоциацию и глубокую экономическую интеграцию с взаимным свободным доступом на рынки.

В принципе такие соглашения призваны обеспечить совместное с соседями поддержание на длительную перспективу отношений на основе общих ценностей и в соответствии с принципами демократии, верховенства права, надлежащего управления ( $\mathrm{good}$ governance) и основных свобод. Однако практика показывает, что соглашения об ассоциации нового поколения, в которые входят договорённости о глубокой и всеобъемлющей зоне

\footnotetext{
${ }^{196}$ Lavenex S., Schimmelfennig F. EU rules beyond EU borders: theorizing external governance in European policy // Journal of European Public Policy. 2009.Vol. 16. Issue 6. P. 796.

${ }^{197}$ Подробнее об этом см.: Danrowski Marek. EU Association Agreement Could Help Ukraine to Reform. Blog Post. 16 March 2016. URL: http://bruegel.org/2016/03/eu-association-agreement-could-help-ukraine-to-reform/

${ }_{198}$ Youngs R. Fine-Tuning EU Support for Ukrainian Democratization // Policy Outlook. 06.04.2016. [Electronic resource]. - Mode of access: http://carnegieeurope.eu/publications/?fa=63250.
} 
свободной торговли, вероятно, не в равной мере подходят не всем странам, которым они были предложены.

В список основных приоритетов этих стран на самом деле не входит сближение с ЕС в законодательном регулировании. В настоящее время многие внутри Евросоюза соглашаются с тем, что таким странам, вероятно, лучше подошла бы более лёгкая форма взаимодействия. Однако теперь ЕС тем труднее отступиться от реализации идеи глубокой и всеобъемлющей зоны свободной торговли с Украиной, Молдовой и Грузией, что пока он однозначно выбрал линию бескомпромиссного соперничества с Россией в определении их дальнейшей судьбы.

Методология, используемая в ЕПС, как уже сказано, позаимствована из опыта расширения Евросоюза, однако данная политика полноправного вхождения в ЕС странамсоседкам формально не обещает. Исходя из успехов процесса расширения, создатели политики соседства основывались на довольно высокомерном допущении, что на реформирование государственного аппарата и экономические реформы в соседних странах Евросоюзу достаточно воздействовать, в качестве рычага, «морковкой» обещаний, в случае их усердия, допустить эти страны на свой рынок, открыть для них безвизовый въезд в ЕС и в принципе развивать с ними более тесное сотрудничество.

Однако подобный менторский подход, явно переоценивающий притягательность интегрированной Европы, на практике показал свою несостоятельность, в особенности для тех стран, которые не ищут более тесной ассоциации с ЕС. Опыт решения в ЕС греческой долговой проблемы выглядит в глазах их граждан весьма непривлекательным. Для них зачастую соображения по поводу безопасности превалируют над идеями продвижения экономических интересов или ценностей. В то же время отсутствие твёрдого обещания грядущего членства в ЕС разочаровывает те страны (Украина, Грузия, Молдова), которые к этому, напротив, явно стремятся.

С институциональной точки зрения, Европейской комиссии в ЕПС отведена очень важная роль. Она осуществляет управление в ежедневном режиме, готовит проекты стратегических докладов и планов действий. Занимается этой политикой Генеральный директорат по переговорам о соседстве и расширении (the Directorate-General for Neighbourhood and Enlargement Negotiations - DG NEAR), в сфере ответственности которого также координация отношений со странами Европейского экономического пространства (Норвегия, Исландия и Лихтенштейн) и Европейской ассоциации свободной торговли (куда, помимо указанных стран, входит также Швейцария). В вопросах ЕПС он сотрудничает с ЕСВД и с рядом «тематических» генеральных директоратов (по торговле, по развитию, по энергетике, по мобильности и транспорту).

Формально намерение ЕС состоит в поддержке структурной трансформации восточных и южных соседей, в продвижении демократии, верховенства закона и институтов рыночной экономики. Но к настоящему времени большинство наблюдателей согласны в том, что эта политика не оправдывает возложенных на неё ожиданий. Серьёзную проблему составляют как концептуальные изъяны, так и непоследовательная имплементация.

Контроль Евросоюза над соответствием экономических и политических реформ в странах-соседках нельзя назвать сильной стороной ЕПС (юридическая подотчётность в данном случае отсутствует). Максимум, что можно отметить, так это «тень иерархии», которая сопровождает переговоры ЕС с партнёрами по ЕПС. Последние могут ожидать неких благ в будущем, в том числе маячащей вдали возможности присоединиться к ЕС в качестве полного члена, в обмен на последовательное соблюдение выдвигаемых Евросоюзом условий. Подобно практике, укоренившейся в сфере расширения, работают процедуры мониторинга (регулярные отчёты стран-соседок), позволяющие ЕС тщательно отслеживать их успехи в данном отношении, как и недочёты в различных областях. Но в конечном счёте, всякие переговоры между Евросоюзом и отдельными странами ЕПС являются 
асимметричными в том смысле, что Евросоюз неизменно занимает в них превосходящее партнёра положение.

Некоторые элементы применяемой ЕС кондициональности весьма обременительны и носят бюрократический характер, а также не имеют отношения к утверждению демократии. Есть основания для вывода о том, что ЕС порой более озабочен гармонизацией технических стандартов, упирая на программы по профессиональной подготовке и развитию компетенций, нежели продвижением ключевых политических реформ.

С точки зрения замысла, эта политика евроцентрична. Роль третьих стран в регионе соседства Евросоюза (не только России, но также стран Персидского Залива, Ирана, Турции и Китая) зачастую просто игнорируется. Между тем, некоторые из перечисленных стран предоставляют странам данного региона существенные финансовые средства, не обставляя свою помощь политическими условиями в западном стиле. Разработанные в расчёте на долговременное взаимодействие в стабильных условиях, инструменты ЕПС не срабатывают в обстановке радикальных изменений, которые большинство соседей Евросоюза переживают в настоящее время.

В 2011 и 2015 гг. политика соседства пересматривалась, что было вызвано её суровой критикой в европейских политических и академических кругах. $\mathrm{B}$ результате последовательных пересмотров ЕС несколько отошёл от единообразного навязывания «соседям» собственных моделей развития и более явно сосредоточился на решении таких задач, как обеспечение региональной стабильности, безопасности и контролирование миграции, основой для чего должны послужить взаимные интересы в торговле, инвестициях и энергетическом сотрудничестве.

Тесное взаимодействие с «соседями» в вопросах обеспечения внутренней безопасности, охраны границ и борьбы с терроризмом, развивающееся уже в течение ряда лет, в последнее время интенсифицировалось и обсуждается более открыто. В совместном информационном послании Комиссии и Верховного представителя о будущем европейской политики соседства, обнародованном в ноябре 2015 г., демократизация более не рассматривается как императивная её часть. Теперь ЕС намерен поддерживать демократии только там, где они возникают - но в упомянутом послании непосредственно упоминаются исключительно Тунис и Грузия как позитивные примеры в данном отношении.

Согласно оценкам Трансперенси Интернэшнл, во всех странах-соседках, за исключением Грузии, коррупция в период с 2003 по 2013 гг. на деле не снизилась, а возросла. Деловой климат улучшился в большинстве из них, но, по оценкам Всемирного банка, только Грузия, Армения и Беларусь входят в список 50 стран с наилучшим деловым климатом ${ }^{199}$.

Актуальным примером того, в чем заключаются сильные и слабые стороны ЕПС, являются украинские события. Соглашение об ассоциации ЕС с Украиной представляет собой новую модель ассоциации, основанную на двух элементах:

1) продвинутая политическая ассоциация (политический диалог, сотрудничество в сфере внешней политики и политики безопасности, а также в сфере внутренних дел и юстиции);

2) далеко идущая экономическая интеграция (соглашение о свободной торговле, предоставляющее Украине доступ на единый внутренний рынок ЕС и распространяющее на неё европейское законодательство).

Предусмотрена постепенная экономическая интеграция, включая создание глубокой и всеобъемлющей зоны свободной торговли, сближение в области законодательства и регулирования. Намечается слияние не только экономических, но и правовых порядков, на

\footnotetext{
199 Исследование Всемирного банка: Ведение бизнеса в 2016 году. [Electronic resource]. - Mode of access: http://gtmarket.ru/news/2015/10/28/7261.
} 
деле превращающее Украину в часть правовой системы ЕС. Это правовой инструмент интеграции через ассоциацию 200.

Подразумеваются четыре рыночные свободы (их возможная реализация носит ограниченный масштаб, за исключением свободы передвижения товаров), а также экономическое и регуляторное сближение в ряде отраслей, включая энергетику. Свобода передвижения услуг, платежей и капиталов, а также украинской рабочей силы, нанятой на территории какого-либо из государств-членов на законных основаниях, подлежит определённым ограничениям.

Преференциальный торговый режим был в одностороннем порядке предоставлен Евросоюзом Украине ещё на стадии временного применения Соглашения об ассоциации (до завершения процесса ратификации). 16 апреля 2014 г. ЕП и Совет приняли регламент № 374 об одностороннем снижении или устранении таможенных платежей на товары, исходящие из Украины. С 1 января 2016 г. ему на смену пришёл режим временного применения Соглашения об ассоциации. Взамен Украина в начале декабря 2015 г. взяла на себя обязательство к началу 2016 г. ввести у себя почти 15000 новых государственных стандартов, смоделированных по образцам ЕС, отменив тем самым прежние стандарты, унаследованные с советских времён. Целью является создание экономического пространства $^{201}$, схожего с тем, что связывает ЕС с Норвегией, Исландией, Лихтенштейном и (отдельно) со Швейцарией, а также с таможенными союзами ЕС с Турцией, Андоррой, СанМарино и Монако.

Вместе с тем украинские события подтолкнули политизацию ЕПС, несмотря на то, что изначально эта политика преподносилась как средство модернизации, а вовсе не как политический инструмент. Более того, объединение вопросов расширения и соседства в одном ключе подтверждает, что политика соседства есть, по сути, инструмент геополитики для Евросоюза. Хотя в повестке дня отношений ЕС с Украиной стоит рыночная интеграция, прогресс в этом отношении остаётся очень ограниченным. Тем не менее, как мы видим, ЕС снижает тарифные барьеры для партнёров и проводит асимметричную политику открытости в их пользу.

В условиях политического кризиса власти Украины были вынуждены прибегнуть к помощи своих международных партнеров, главным образом, ЕС и МВФ. При этом Комиссия четко обрисовала, при каких условиях и в какие сроки возможно предоставление финансовой помощи Украине ${ }^{202}$. Пытаясь соответствовать европейским стандартам и в надежде на получение очередных траншей макрофинансовой помощи от ЕС (главным образом, кредиты, предоставляемые Европейским инвестиционным банком и Европейским банком реконструкции и развития), власти Украины в режиме ускоренного обсуждения проводят реформы, которые сами по себе являются весьма позитивными, но, при наложении на украинскую действительность, едва ли возымеют должный эффект на деле. В частности, речь идет о снятии запрета на экспорт древесины, снятии фитосанитарных барьеров в торговле (например, продуктами животного происхождения). Также правительство Украины должно обеспечить надлежащий бизнес-климат и сделать реальные шаги в борьбе с коррупцией. Наблюдатели практически единодушны в том, что темп реформ оставляет

\footnotetext{
${ }^{200}$ Hillion Ch. Integrating an Outsider: An EU Perspective on Relations with Norway // Europautredningen, Rapport №16. 2001. [Electronic resource]. - Mode of access: http://www.europautredningen.no/wpcontent/uploads/2011/04/Rap16-E\%C3\%98S-sett-fra-EU.pdf

${ }^{201}$ European Commission. Review of the European Neighbourhood Policy. Joint Communication to the European Parliament, the Council, the European Economic and Social Committee and the Committee of the Regions, Brussels, 18 November 2015, doc. JOIN(2015) 50 final. [Electronic resource]. - Mode of access: http://eeas.europa.eu/enp/documents/2015/151118 joint-communication_review-of-the-enp_en.pdf.

${ }^{202}$ European Commission's support to Ukraine. [Electronic resource]. - Mode of access: http://europa.eu/rapid/pressrelease_MEMO-14-159_en.htm.
} 
желать лучшего, причём им сопротивляются как Верховная рада Украины, так и официальные лица в украинском правительстве 203.

C точки зрения самих украинцев, излишние условия порой выдвигаются им со стороны ряда стран ЕС (о федерализации и нейтральном статусе) с целью умиротворения России, а вовсе не из искренней заботы об украинской демократии ${ }^{204}$, тогда как бесконечное обсуждение вопроса об отмене виз, не находя до сих пор своего разрешения, становится раздражающим украинское общество, а не стимулирующим к реформам фактором.

Предложение о безвизовых поездках для граждан Украины в рамках Шенгенской зоны (кратковременные поездки, не предполагающие разрешения на работу) является объектом формального обсуждения с 2008 г. Диалог о либерализации визового режима ЕС ведет не только с Украиной, но ещё с Грузией и Молдавией. В Европейской комиссии этим вопросом занимается Генеральный директорат по миграции и внутренним делам, который разрабатывает соответствующие планы действий по поэтапной отмене визового режима.

В числе условий, выдвигаемых ЕС и МВФ, находятся также борьба с коррупцией и реформы в энергетическом секторе Украины, который считается крайне неэффективным и одним из главных источников олигархической коррупции. Основу последней составляет сложная система взаиморасчётов, сочетающаяся с разными ценами на газ для разных потребителей и с компенсациями государством разницы в цене, что приводило к злоупотреблениям. Планы по реформированию энергетического сектора Украины при международной поддержке, сформулированные уже несколько лет тому назад, так и не были претворены в жизнь. МВФ потребовал сокращения субсидий в энергетике, Евросоюз выполнения обязательств Украины по либерализации газового рынка, связанных с её участием с 2011 г. в Энергетическом сообществе ${ }^{205}$. Эти условия включают основные аспекты так называемого Третьего энергетического пакета ${ }^{206}$ - дробление НАК «Нафтогаз Украины» по отдельным видам деятельности и демонополизацию в интересах потребителей. Планируется создать два акционерных общества - «Украинская газотранспортная система» и «Украинские газовые хранилища».

В Голландии 6 апреля 2016 г. состоялся референдум по вопросу о поддержке соглашения ЕС с Украиной, ранее уже одобренного парламентом данной страны. В ходе референдума $61 \%$ голосов было подано против такой поддержки (к этому времени сам ЕС, государства-члены ЕС и Украина соглашение уже ратифицировали). Противники соглашения в Голландии выражали опасения, что из-за него налогоплательщикам придётся в дальнейшем раскошеливаться на растущую финансовую поддержку Украины и, кроме того, волна иммиграции из этой страны возрастёт дополнительно. Референдум был отлагательный и совещательный, т.е., с формальной точки зрения, он всего лишь отодвигал вступление в силу национального акта об одобрении данного соглашения на время до получения результатов голосования. Правительство Голландии не было обязано учитывать эти результаты. Явка на референдуме составила $32 \%$ (при необходимом минимуме в $30 \%$ ). Понятно, что это событие не добавило стабильности или последовательности процессу принятия внешнеполитических решений в ЕС. Тем не менее, премьер-министр ГолландииМарк Рютте заявил, что его правительство учтёт результаты апрельского

\footnotetext{
${ }^{203}$ Lasocki J. How EU conditionality is helping to transform Ukraine// European Council on Foreign Relations. Commentary. 22.03.2016. [Electronic resource]. - Mode of access: $\mathrm{http} / / / \mathrm{www} . e c f r . e u /$ article/commentary_how_eu_conditionality_is_helping_to_transform_ukraine6046.

${ }^{204}$ European Council on Foreign Relations. What does Ukraine Think? [Electronic resource]. - Mode of access: http://www.ecfr.eu/page/-/WHAT_DOES_UKRAINE_THINK_pdf.pdfP.22.

${ }^{205}$ Об участии Украины в Энергетическом сообществе ЕС подробнее см.: Конопляник А. Вхождение Украины в Договор об Энергетическом сообществе ЕС со странами Юго-Восточной Европы: последствия для всех заинтересованных сторон // Нефть и газ. 2010. № 6. С. 20-36.

${ }^{206} \mathrm{O}$ третьем энергетическом пакете ЕС см., в частности: Кавешников Н.Ю. Многоликая энергетическая безопасность // Международная жизнь. Декабрь 2011. С.99.
} 
референдума, что поставило под вопрос окончательное вступление Соглашения в силу. В настоящее время кабинет министров Голландии продолжает переговоры с оппозиционными партиями страны, изыскивая возможности для компромисса по вопросу о Соглашении ЕС с Украиной.

Запуская политику соседства в 2004 г., в ЕС намеревались окружить себя кольцом друзей, сформировать пространство процветания, стабильности и безопасности, но политические события и кризисные явления, с которым столкнулись соседние с Европой страны, показали, что ЕПС не является эффективным механизмом реагирования на чрезвычайные ситуации или их предупреждения. Уже в 2011 г. ЕПС вполне продемонстрировала свою несообразность в отношении тех перемен, которые произошли в странах Ближнего Востока и Северной Африки. ЕС и его партнеры столкнулись с экономическим и социальным давлением, притоком беженцев и мигрантов и угрозами безопасности. Все эти сложно предсказуемые события наслоились на слабые стороны ЕПС, которые волей-неволей были заложены в ней изначально. Иными словами, в своих архитектурных формах ЕПС отталкивалась от политики расширения, но при этом не содержала столь же убедительных стимулов для стран, на которые она была направлена, чтобы те подчинялись указаниям со стороны ЕС. В результате это привело к разочарованию и неудовлетворенности как в странах-партнёрах, так и в самом Евросоюзе.

Вместе с тем, за годы проведения политики соседства ЕС получил колоссальный опыт взаимодействия со странами своего ближнего зарубежья, из чего Евросоюз вынес несколько важных уроков. Во-первых, официальный Брюссель почувствовал, что далеко не все партнёры в равной степени заинтересованы в углублении отношений по модели политического плюрализма и интеграции. Более того, по ряду направлений ЕС столкнулся с конкуренцией интересов и борьбой за сферы влияния, что также стало важным внешнеполитическим сигналом для ЕС, своего рода «обратной связью». Во-вторых, переживая крупнейший за последний годы экономический кризис, ЕС осознал конечность своих ресурсов, а вместе с этим и определенную черту в распространении общеевропейских ценностей, дальше которой он идти не готов. В-третьих, проведение политики соседства помогло ЕС узнать ближе своих соседей и соотнести свои собственные интересы и амбиции с их интересами. Та доза разочарования, которую получил ЕС, мотивирует его искать более эффективные внешнеполитические инструменты.

Вышесказанное, в частности, побуждает Евросоюз к переходу от многосторонней «архитектуры» к двустороннему формату в отношениях со странами-соседками и к меньшему упору на кондициональность. Однако всё это не означает, что Евросоюз полностью отказался от своего прежнего ценностного подхода в отношениях с соседними государствами. Напротив, усвоенные уроки лишь укрепили намерение единой Европы вовлекать своих соседей в диалог и сотрудничество по линии гражданского общества, но теперь лишь в той мере и в тех формам, к которым готовы сами партнёры (по отдельности). При этом, в силу разного уровня амбиций своих партнёров (восточных и южных), ЕС оставляет за ними право собственного выбора, что говорит о Союзе как о взвешенном игроке на внешнеполитической арене ${ }^{207}$.

Как и ранее, от Брюсселя звучат призывы к упрочению демократии, обеспечению достойного управления и соблюдению прав человека. Продолжается выполнение европейских программ в поддержку развития в странах, на которые распространяется политика соседства, систем судопроизводства, государственной администрации и гражданского общества, т.е. в тех областях, где у ЕС накоплен особенно богатый опыт. Но главная политическая идея, составлявшая стержень ЕПС, которая заключалась в подразумеваемой способности Евросоюза трансформировать своих соседей в либеральном

${ }^{207}$ EUISS Yearbook of European Security. YES 2016 / Paris: European Union Institute for Security Studies, 2016. P. 186. 
духе, к настоящему времени практически выветрилась. Это произошло не в силу смены убеждений в Европе, но из-за понимания слабости самого Евросоюза, проявившейся перед лицом многочисленных международных кризисов недавнего времени.

Вместе с тем, несмотря на более чем десятилетний срок функционирования ЕПС, однозначные итоги этой политики в настоящее время подвести сложно. В программных документах по политике соседства ЕС открыто заявляет о необходимости пересмотреть её принципы и механизмы функционирования, но лишь с целью сделать ЕПС более эффективной - о том, чтобы отказаться от этой политики речи не идёт. Из чего можно заключить, что, во-первых, ЕС все-таки удалось извлечь из политики соседства определенное рациональное зерно; во-вторых, Европейская политика соседства на данный момент не исчерпала свой потенциал в качестве средства поддержания общей стабильности, безопасности и процветания для ЕС и его стран-партнёров.

Важно подчеркнуть, что какие бы противоречивые оценки ни получала политика соседства, тем не менее, этот механизм заставляет менять государственное законодательство те страны, на которые он распространяется, что само по себе является нечастым прецедентом во внешней политике. В дальнейшем ЕС планирует более тесную интеграцию политики соседства с общей внешней политикой, о чем заявил председатель ЕК Ж.-К. Юнкер, призывая страны-участницы ЕС внести свои новые предложения о реформировании ЕПС. Параллельно с этим, Комиссия пересматривает цели и перспективы по дальнейшему расширению ЕС. Отметим, что в своей политической программе Юнкер заявил, что в ближайшие пять лет присоединения новых стран к ЕС не предполагается ${ }^{208}$.

В целом, для оценки эффективности европейской политики соседства сложно найти объективные критерии, поскольку традиционные государствоцентричные подходы едва ли могут быть применимы к ЕС. Не стоит забывать, что в составе ЕС находятся государства, активно и последовательно проводящие собственный внешнеполитический курс. Евросоюз представляет собой принципиально иное формирование, требующее другого подхода к оценке своей внешнеполитической деятельности.

Главное, что предъявляет ЕС в доказательство своей эффективности - это 70 лет мира $^{209}$. Не стоит умалять значение этого достижения для континента, который за свою многовековую историю не знал столь длительного периода отсутствия войн.

\footnotetext{
${ }^{208}$ Juncker J.-C. A New Start for Europe: My Agenda for Jobs, Growth, Fairness and Democratic Change. Political Guidelines for the next European Commission. [Electronic resource]. - Mode of access: https://ec.europa.eu/priorities/sites/beta-political/files/juncker-political-guidelines-speech_en_0.pdf.

${ }^{209}$ Juncker J.-C. State of the Union Address 2016: towards a better Europe a Europe that protects, empowers and defends. Strasbourg, 14 September 2016. [Electronic resource]. Mode of access: http://europa.eu/rapid/pressrelease_SPEECH-16-3043_en.htm.
} 


\section{§ 3.5 ОБЩАЯ ВНЕШНЯЯ ПОЛИТИКА И ПОЛИТИКА БЕЗОПАСНОСТИ}

Серия югославских войн, начавшись в 1991 г., в полной мере проявила неспособность интегрированной Европы к решительным внешнеполитическим действиям. Тогда это побудило страны ЕС добиваться большего сплочения своих усилий. Опираясь на ранние шаги в деле межправительственной координации внешней политики государств-членов западноевропейских экономических сообществ, Маастрихтский договор 1992 г. о Европейском союзе формально учредил Общую внешнюю политику и политику безопасности ЕС, относящуюся к сфере «высокой» политики. Необходимо уточнить, что в соответствующих вопросах последнее слово до сих пор остаётся за правительствами государств-членов - слово «общая» в данном случае подразумевает, что 28 суверенных правительств работают вместе в той мере, в какой они способны достичь консенсуса в каждом отдельно взятом вопросе.

ОВПБ появилась в 1993 г. как «собственная» внешняя политика, позволившая ЕС заявить о себе на международной политической арене. Но она с самого начала страдала от серьёзных структурных недостатков. Государства-члены, у каждого из которых были свои внешнеполитические возможности и идеи на данный счёт, из-за большого числа разногласий между ними, сумели договориться на европейском уровне лишь о таких институциональных рамках, которые отличались административной неповоротливостью и не открывали лазеек для передачи полномочий общим институтам. Лиссабонский договор укрепил роль Верховного представителя ЕС по иностранным делам и позволил создать ЕСВД, а также передал в ведение последней военно-политические аспекты внешней политики ЕС, но такие направления, как рассмотренная выше Европейская политика соседства, были оставлены Комиссии.

В конечном счёте, такая внешняя политика, которую проводят государства, остаётся для ЕС недоступной до сих пор, поскольку его не назовёшь цельным самостоятельным актором, у которого имелась бы хорошо продуманная стратегия в отношении зарубежных стран. Государства-члены ЕС, действуя поодиночке, по-прежнему ведут, пусть в урезанных или остаточных формах, собственный курс в общении и с третьими странами, и с международными организациями. По каждому вопросу им приходится координировать свои курсы заново, причём возможность одностороннего действия всегда остаётся для них в запасе.

Главными институтами в сфере ОВПБ являются Европейский совет и Совет. Каждое государство-член может адресовать Совету вопросы и выступать с собственными инициативами и предложениями. В то же время Лиссабонский договор требует, чтобы они координировали свои действия в международных организациях и на международных конференциях.

Инструментами ОВПБ по Лиссабонскому договору выступают решения четырёх типов:

(1) по стратегическим целям и интересам EC;

(2) по общим позициям;

(3) по совместным действиям;

(4) по имплементации общих позиций и совместных действий.

Общие позиции нередко напоминают о целях ЕC и определяют коллективный, согласованный дипломатический подход к определённому региону или какой-то стране. Они могут адресоваться при этом к какой-то проблеме, например, к подразумеваемому нарушению иностранным правительством принципов соблюдения прав человека, демократии или международного права. Возможны и общие позиции по таким транснациональным вопросам, как предотвращение и разрешение конфликтов, 
нераспространение оружия массового поражения, контроль над вооружениями и борьба с терроризмом. Вопрос о санкциях может быть включён, в качестве одного их элементов, в общую позицию более широкого охвата. Совместные действия часто касаются запуска либо продления зарубежных гражданских миссий или военных операций по линии ОПБО.

По своей природе все эти инструменты составляют отдельную категорию принимаемых в ЕС решений и находятся в некоей «серой зоне» между законодательством и политическим сотрудничеством. Они обязательны для исполнения, но юрисдикция Суда ЕС в соответствующих вопросах остаётся относительно слабой.

Формально ОВПБ является главным направлением действий Евросоюза в сфере внешней политики, безопасности и обороны, но её бюджет весьма невелик (в том числе в сравнении с некоторыми бюджетами других политик из внешнеполитического «пула», которыми занимается Комиссия). Нынешние многолетние финансовые рамки на 2014-2020 годы предусматривают общий бюджет по линии «Глобальная Европа» в сумме 66 млрд. евро при бюджете ОВПБ в сумме 2,3 млрд. евро.

Комиссия между тем отвечает и за ведение бюджета ОВПБ. Совет с годами нарастил изощрённый аппарат, помогавший ему готовить, осуществлять и контролировать внешнеполитические действия ЕС, который теперь по большей части передан ЕСВД. В рамках Совета общим мониторингом ОВПБ и ОПБО, а также осуществлением политического контроля и стратегического руководства в отношении операций по урегулированию кризисов (согласно статье 38 ДЕС) занимается Комитет по политике и безопасности - КПБ (Political and Security Committee- PSC). Кроме того, имеется также Генеральный директорат С по внешней политике, расширению и гражданской обороне, входящий в Секретариат Совета ${ }^{210}$.

КПБ является постоянным органом, куда входят представители государств-членов в ранге послов, который находится в Брюсселе. Он формулирует мнения по соответствующим вопросам по запросу Совета, Верховного представителя либо по собственной инициативе. ПостоянныйпредседательКПБнапрямуюсвязансколлегиальнымуправлениемЕСВД. ВработеемупомогаютВоенныйкомитетиКомитетпогражданскимаспектамурегулирования кризисов.

Единогласие является общим правилом при принятии решений в сфере ОВПБ. Однако члены Совета имеют возможность воздерживаться при голосовании, а также сделать формальное заявление о таком намерении. Это даёт им возможность не участвовать в выполнении конкретного решения, которое во всём прочем является для Евросоюза обязательным. Если число членов Совета, продекларировавших такое намерение, составляет более одной трети государств-членов, соответствующее решение не принимается.

В области внешней политики Совет действует квалифицированным большинством только в следующих случаях:

(1) принимая решение, определяющее действие или позицию Союза, на основании решения Европейского совета, относящегося к обеспечению стратегических интересов и целей ЕС;

(2) принимая решение, определяющее действие или позицию Союза, по предложению Верховного представителя по иностранным делам, реагирующего на специальный запрос Европейского совета;

(3) принимая любое решение по имплементации уже принятого решения об акции или позиции Союза;

(4) при назначении специального представителя;

(5) Европейский совет может единогласно принять решение, на основании которого Совет должен будет действовать квалифицированным большинством

${ }^{210} \mathrm{http} / /$ www.consilium.europa.eu/en/general-secretariat/secretary-general/ 
в случаях, не относящимся к перечисленным выше (за исключением решений, которые имеют военные или оборонные последствия - статья 31(3) ДЕС).

Конечно, все эти исключения не подрывают сохраняющейся центральной значимости единогласия при принятии сугубо внешнеполитических решений. Путь перехода от единогласия к квалифицированному большинству находится под надежной защитой и будет немедленно перекрыт, если у государств-членов возникнут опасения по поводу ущерба, наносимого жизненно важным национальным интересам.

В сфере ОВПБ (как и в рамках неисключительной компетенции Союза в принципе) возможно также продвинутое, или углублённое, сотрудничество (enhanced cooperation $)^{211}$. нём участвуют не все государства-члены, но не менее девяти из них. Соответствующее решение принимается Советом ЕС единогласно, но только в качестве последнего средства когда Совет установит, что цели, преследуемые данным сотрудничеством, не могут быть в разумный срок достигнуты Союзом в целом.

По статье 329(2) ДФЕС, государства-члены, которые желают установить между собой продвинутое сотрудничество в рамках общей внешней политики, направляют свою заявку в Совет, которые передаёт её Верховному представителю по иностранным делам. Верховный представитель даёт заключение о согласованности намеченного продвинутого сотрудничества с ОВПБ, а Комиссия - заключение относительно его согласованности с другими направлениями политики Союза. Европейский парламент лишь информируется о происходящем. Если инициатива о продвинутом сотрудничестве уже одобрена Советом, то все члены Совета вправе участвовать в его обсуждениях, но лишь государства-члены, участвующие в данной инициативе, отныне голосуют по решениям, его касающимся.

К ЕСВД теперь отошли структуры по урегулированию кризисов, которые раньше входили в Секретариат Совета. Они находятся под прямой властью Верхового представителя (см. схему 2-4). Директорат по кризисному урегулированию и планированию (учреждён в 2008 г.) отвечает за политико-стратегическое планирование гражданских миссий и военный операций, а также за их критический анализ. Хотя ЕС проводит больше гражданских миссий, нежели военных операций, среди сотрудников Директората, напротив, больше людей с военным опытом. Отдел по планированию гражданских миссий (Civilian Planning Conduct Capability - CPCC) насчитывает около 60 человек, включая постоянных и временно прикомандированных от отдельных стран экспертов, которые из Брюсселя координируют и поддерживают гражданских сотрудников, работающих в миссиях на местах (примерно три тысячи человек). Главой Отдела является командующий гражданскими миссиями, который подчиняется Верховному представителю по иностранным делам и, через него/неё - Совету.

Военный штаб ЕC (EU Military Staff - EUMS) был передан из Секретариата Совета в ЕСВД в 2011 г. Он работает под руководством Рабочей группы Военного комитета ${ }^{212}$ (в Комитет входят главы министерств обороны государств-членов) и подчиняется Верховному представителю. Военный штаб занимается ранним предупреждением, оценкой ситуации и стратегическим планированием для миссий по линии ОПБО. Он включает офисы по связи с ООН и с НАТО, а также звено в Штабе верховного главного командования Объединённых вооружённых сил НАТО в Европе для тех операций, в которых используются возможности и потенциал НАТО согласно договорённостям Берлин-плюс ${ }^{213}$.

\footnotetext{
211 Положения о продвинутом сотрудничестве см. в статьях 20 ДЕС и статьях 326 - 334 ДФЕС.

${ }^{212} \mathrm{http}$ //www.consilium.europa.eu/en/council-eu/preparatory-bodies/european-union-military-committee-workinggroup/

213 Договоренности «Берлин плюс» служат основой для взаимодействия НАТО-ЕС при урегулировании кризисов. Евросоюзу обеспечивается доступ к коллективным силам и средствам НАТО при проведении операций под его руководством, включая механизмы управления и помощь при оперативном планировании. Они позволяют Североатлантическому союзу поддерживать операции под руководством ЕС, в которых НАТО не задействована как организация. См.: http://www.nato.int/cps/ru/natohq/topics 49217.htm.
} 
Комитет по гражданским аспектам управления кризисами (Committee for Civilian aspects of Crisis Management - CIVCOM) является совещательным органом, консультирующим КПБ и получающим от него руководящие указания.

Ситуационный центр EC (EU SituationCentre - SITCEN) является «разведывательным центром» Евросоюза. Это подразделение ЕСВД, которое служит для информации и координации деятельности ситуационных центров в государствах-членах и в некоторых третьих странах. Он проводит мониторинг международной ситуации, сосредоточиваясь на определенных регионах и сложных вопросах - таких как терроризм и распространение оружия массового уничтожения. Он обеспечивает экспертный анализ для своевременного принятия решений по линии ОВПБ и ОПБО.

Межправительственное Европейское оборонное агентство (ЕОА), созданное в 2004 г., поддерживает государства-члены в их усилиях по совершенствованию европейского оборонного потенциала. ЕОА фактически находится под властью Совета, перед которым оно отчитывается и от которого принимает указания. В нём участвуют все государства-члены, за исключением Дании. EOA поддерживает государства-члены и Совет в усилиях по совершенствования европейского оборонного потенциала. Государства-члены вкладывают свои средства в ежегодный бюджет Агентства в соответствии с формулой, привязанной к показателю ВНП ${ }^{214}$. Его рабочий план зависит от одобрения государств-членов. Последние могут решать, участвовать или не участвовать в проектах Агентства (касающихся возможностей дозаправки самолётов в воздухе, сотрудничества военно-медицинских служб, преодоления нехватки вертолётов для операций по управлению кризисами и др.), исходя из национальных потребностей. ЕОА подписало административные соглашения с Норвегией (2006), Швейцарией (2012), Сербией (2013) и Украиной (2015), что даёт указанным странам возможность участвовать в его проектах и программах. Чтобы вступить в силу, такие административные соглашения нуждаются в одобрении Европейского совета. Как заключает российский автор Сергей Андрюшенко, стратегические инициативы ЕОА «отличаются от национальных стратегий необязательностью их исполнения. ...Они представляют собой набор программных документов, которыми следует руководствоваться при определении национальных оборонных программ и военных исследований и разработок. ...Однако у данного института имеется значительный потенциал, который может быть реализован через углубление интеграции и придание Агентству более широких наднациональных функций в области безопасности и обороны» ${ }^{215}$.

Лиссабонский договор уточняет типы кризисного урегулирования (гражданское или военное) и расширяет список «Петерсбергских задач» ${ }^{216}$, составляющих основу ОПБО, добавляя к нему возможность проведения операций по разоружению, предотвращению конфликтов и постконфликтной стабилизации, а также военных консультаций и оказанию помощи. Он также увязывает «Петерсбергские задачи» с борьбой против международного терроризма.

Процесс принятия решений в ЕС в связи с тем или иным кризисом выстраивается следующим образом.

Политическая фаза

1. КПБ, действуя при поддержке различных консультативных органов, а также географических и тематических департаментов ЕСВД, оценивает

\footnotetext{
214 Валовый национальный продукт.

215 Андрюшин С.В. Стратегический потенциал Европейского оборонного агентства // Вестник СПбГУ. Сер. 6. 2015. Buın. 1. C. 97-110. URL: http://vestnik.spbu.ru/html15/s06/s06v1/12.pdf.

${ }^{216}$ Петерсбергские задачи - меры гражданского и военного характера, применяемые при кризисном управлении (предусматриваются гуманитарная помощь и операции по спасению, меры по сохранению мира и применение военной силы для преодоления кризисов, включая миротворческие мероприятия).
} 
целесообразность действий ЕС в конкретной ситуации. Если Комитет принимает решение, что такие действия целесообразны, то начинается их планирование.

2. Директорат по кризисному урегулированию и планированию разрабатывает концепцию урегулирования данного кризиса, в которой излагаются связанные с ним политические интересы ЕС, практически осуществимые варианты действий с его стороны (гражданские или военные) и цели возможной гражданской миссии или военной операции. В случае необходимости в ту страну, где ЕС предполагает действовать, может быть в предварительном порядке направлена делегация для ознакомления с положением дел на месте, для установления предварительных контактов с правительством данной страны и выработки рекомендаций касательно форм вовлечения Евросоюза в складывающуюся там ситуацию.

3. КПБ завершает работу над концепцией кризисного урегулирования и направляет её в КОРЕПЕР (вспомогательная инстанция Совета) и непосредственно в Совет для формального одобрения.

Стратегическая фаза

4. В зависимости от оценки конкретной ситуации, Военный штаб разрабатывает варианты военных действий, а Отдел по планированию гражданских миссийневоенных действий (в политической или гражданской области), к которым Комитет по гражданским аспектам управления кризисами иВоенный штаб предлагают свои замечания.

5. КПБ готовит проект решения по различным вариантам и передаёт его в КОРЕПЕР и Совет.

Запуск операции/миссии

6. Совет принимает формальное решение. Оно содержит мандат миссии или операции, на основании которого назначается её глава.

7. Назначенный командующий операцией / руководитель миссии ответственен за выработку общего замысла операции/миссии и оперативного плана действий.

8. После одобрения этих документов Совет запускает операцию/миссию, которая проводится под политическим контролем и стратегическим руководством КПБ.

Поскольку сотрудничество в рамках ОВПБ остаётся межправительственным по своему характеру, функция демократического контроля над имплементацией соответствующих решений правительствами закономерным образом сохраняют за собой национальные парламенты. Но эти парламенты имеют ограниченный доступ к соответствующей информации, а депутаты в целом не могут похвастать хорошим пониманием сюжетов европейской внешней политики. К тому же у отдельных национальных парламентов в Европе различный круг компетенций и не совпадающие процедуры, что затрудняет их сотрудничество между собой, тогда как Европарламент не имеет формальных оснований, чтобы всецело их заменить в данной области.

В Лиссабонском договоре нет чётких указаний, как решать такую проблему. Тем не менее, на основании Протокола о роли национальных парламентов в ЕС, прилагаемого к Лиссабонскому договору, в 2012 г. была учреждена Межпарламентская конференция по вопросам ОВПБ и ОПБО (её пленарные сессии проводятся ежегодно), в работе которой вместе участвуют представители национальных парламентов государств-членовЕС и ЕП. Она весьма слаба в институциональном отношении (там действует правило единогласия, заключения Конференции не носят обязательного характера). Её главная ценность - в появлении платформы, которая позволяет организовывать межпарламентские слушания и готовить предложения национальных парламентов по внешнеполитическим вопросам, обращённые к ЕП, Совету и Комиссии.

Преобладание Организации Североатлантического договора (НАТО) в качестве коллективной организации обороны трансатлантического сообщества объясняет, почему 
Общая политика безопасности и обороны в рамках ОВПБ получила столь скромное развитие. Из общего понимания неизбежных слабостей ОВПБ, мало способной к принятию быстрых решений в кризисных ситуациях, возникают контуры особенной общей внешней политики.

Она нацелена на долговременную перспективу формирования устойчивых политических, правовых, социальных и прочих структур, которые могут располагаться на разных подходящих для этого уровнях (индивидуальном, общественном, государственном, региональном, глобальном) определённого пространства. Проводя такую структурирующую внешнюю политику, ЕС ожидает в перспективе появления более благоприятного для себя внешнего окружения (международной среды), стараясь привлечь третьи страны к собственному подходу и пониманию в решении разных вопросов. В этом смысле наиболее успешной внешнеполитической компанией в структурном духе следует, как ни парадоксально, признать восточное расширение ЕС (вхождение в него стран Центральной и Восточной Европы).

Но подобного рода структурная внешняя политика, чтобы быть последовательно успешной, должна быть принята как легитимная теми людьми, которых она затрагивает. Вне пределов собственно ЕС добиться этого довольно сложно. Вызванные её применением изменения в политике, экономике и законодательстве третьих стран должны инкорпорироваться людьми, которых эти изменения затрагивают, в их мировоззрение или идентичность. Легитимность ЕС в качестве глобального игрока со стороны предстаёт не слишком убедительной, особенно в последнее время: представляя себя в качестве нормативной силы, он не дал ответа на кризисы на Балканах и в Ливии, которым можно было бы гордиться, а его сосредоточенность на усилиях по преодолению кризиса в Еврозоне вообще выдают ориентацию скорее вовнутрь, нежели вовне.

Европейская политика безопасности и обороны стартовала в 1998-1999 гг., но до сих пор интеграция в этой области остаётся на низкой стадии. Её развитию препятствовали, в том числе, опасения, что если Евросоюз, как «гражданская сила», обзаведётся военными инструментами, то это негативно скажется на его идентичности. Кроме того, имели место сомнения в плане возможных последствий для отношений европейских стран с США в рамках Североатлантического союза, а также перспектив «проникновения» наднациональности в ОВПБ вследствие оформления «европейской армии» ${ }^{217}$.

Адвокатами интервенционизма в сфере ОПБО традиционно выступали Франция и Великобритания - две ядерные державы в составе ЕС, тратящие более всего средств на оборону. Однако запущенная по инициативе Франции и Великобритании, ОПБО не обрела тех экспедиционных, милитаристских черт, которые в заметной мере присущи воинственным и интервенционистским подходам этих двух стран в международных делах. Но не получилось и «мягкой» гуманитарной организации по поддержанию мира, которая ограничивалась бы действиями по мандату ООН. У каждого из государств-членов своя стратегическая культурная идентичность, и все их в данном случае требовалось свести в единое целое, что не удалось сделать в полной мере.

По очевидным историческим причинам, Германия воздерживалась до сих пор от участия в военных интервенциях (операциях) ЕС. Она выступила, как мы уже упоминали, против акции в Ливии в 2011 г., воздержавшись при голосовании по данному вопросу в Совете Безопасности ООН. Германия также проявила очевидную сдержанность по поводу операции французских вооруженных сил в Мали в 2013 г. (британские войска тоже не приняли в ней участия, однако Великобритания оказала помощь в логистическом сопровождении французской операции). В сирийском вопросе, в отличие от Франции и

\footnotetext{
${ }^{217}$ Salmon T., Shepherd J.K.A. Toward a European Army: A Military Power in the Making? Denver: Lynne Rienner Pub., 2003.
} 
Великобритании, Германия тоже настаивала на поисках, прежде всего, дипломатического решения кризиса.

Решения, относящиеся к ОПБО, как и к ОВПБ в целом, тоже принимают Европейский совет и Совет (статья 42 ДЕС), действуя единогласно - но с некоторыми заметными исключениями, которые касаются Европейского оборонного агентства - ЕОА (решения по нему Совет принимает квалифицированным большинством) и постоянного структурированного сотрудничества (см. далее). С предложениями для таких решений обычно выступает Верховный представитель. Лиссабонский договор установил сцепку между ОПБО и другими политиками Союза, потребовав, чтобы, где это необходимо, ЕОА выполняло свои задачи во взаимосвязи с Комиссией (это затрагивает в особенности вопросы научных исследований, промышленную политику и космическую отрасль).

Сфера ОПБО требует повышенной меры секретности, конфиденциальности и гибкости, чтобы быстро принимать решения, обеспечивающие интересы безопасности как самого ЕС, так и его государств-членов. Можно сказать, что в этой области на европейском уровне воспроизводится присутствующая и на национальном уровне традиция весьма ограниченного парламентского контроля. У ЕП отсутствует формальное право голоса в вопросе выдачи санкции на запуск операций и миссий, будь то военных или гражданских. Тем не менее, после роспуска Парламентской ассамблеи Западноевропейского союза в 2012 г. была создана новая Межпарламентская конференция (с участием 16 представителей ЕП и 6 - от каждого из национальных парламентов) для многоуровневого наблюдения за ОВПБ и ОПБО.

В деле С-658/11 (Парламент против Совета), которое рассматривалось в Суду ЕС, Европарламенту удалось добиться аннулирования решения Совета, касающегося военноморской операции ЕС против морских пиратов у побережья Сомали «Аталанта» на том основании, что Совет не предоставил ЕП достаточную информацию о ней. По рассуждениям Суда ЕС, в результате ЕП лишён был возможности осуществлять в её отношении демократический надзор. Иными словами, Суд ЕС в этом деле решительно встал на защиту процедурного аспекта демократической отчётности на европейском уровне. Решение, принятое Советом и впоследствии отменённое Судом ЕС, в данном случае касалось заключения соглашения между ЕС и Республикой Маврикий об условиях передачи Маврикию лиц, подозреваемых в пиратстве ${ }^{218}$.

Необходимо отметить, что далеко не все действия, предпринимаемые по линии ОПБО, являются исключительно военными. Чаще речь идёт как раз о гражданских действиях (например, повышение квалификации судебных работников или реформа национального сектора безопасности). Проводятся не столько боевые операции в традиционном смысле, сколько операции по поддержанию мира, предотвращению конфликтов, урегулированию кризисов, постконфликтной стабилизации, а также гуманитарные миссии. Европейский совет и Совет министров играют здесь ключевые роли в стратегическом руководстве и в принятии решений, тогда как важнейшие функции Верховного представителя - это помощь государствам-членам в нахождении консенсуса и имплементация.

В институциональном отношении общая политика обороны ЕС особенно слаба. К решению проблемы недостаточного военного потенциала ОПБО в ЕС обращались неоднократно, но по факту мало что было сделано, чтобы такую проблему решить ${ }^{219}$. Отсюда и основной акцент в области ОПБО на предотвращение конфликтов и урегулирование кризисов, а не на наращивание общих возможностей и функций, которые традиционно

\footnotetext{
${ }^{218} \mathrm{http}: / /$ eur-lex.europa.eu/resource.html?uri=cellar:123dd124-b6bc-4c92-ab7b03482fd6cec9.0011.02/DOC_2\&format=HTML\&lang=EN\&parentUrn=CELEX:32011D0640.

${ }^{219}$ Biscop, S. \& Fiott, D. (eds.) The State of Defence in Europe: State of Emergency? // Egmont Paper. 2013. №62. URL: http://www.egmontinstitute.be/wp-content/uploads/2014/01/ep62.pdf.
} 
ассоциируются с военной сферой, включая оборону территории и сдерживание путём устрашения (последние остаются в компетенции НАТО).

Постоянное структурированное сотрудничество нацелено на повышение гибкости в системе ОПБО. В статье 44 ДЕС говорится, что Совет может поручать реализацию миссий ЕС группе государств-членов (числом не менее двух), которые желают этого и располагают для подобной миссии необходимыми военными потенциалами. При участии Верховного представителя по иностранным делам такие государства договариваются между собой об управлении процессом реализации своего сотрудничества в рамках такой миссии. Согласно статье 42(6) ДЕС такие страны формируют самоуправляемую «продвинутую» группу, к которой другие государства ЕС могут присоединиться впоследствии.

Речь не идёт о том, чтобы создать новую категорию операций Евросоюза. Масштаб возможных миссий ОПБО данным положением не расширяется. Оно не открывает путь к альтернативному процессу принятия решений. Его цель - только облегчить развёртывание операций по линии ОПБО, создав для этого такие рамки, которые помогут государствамчленам, желающим участвовать в деле, провести миссию как можно более эффективно, опираясь на общие возможности ЕС. Эта статья не была ещё ни разу задействована на практике.

Оговорка о взаимной помощи в Лиссабонском договоре (статья 42(7) ДЕС) предусматривает, что в случае, если государство-член подвергнется вооруженной агрессии на его территории, другие государства-члены должны оказывать ему помощь и содействие всеми возможными средствами, действуя в соответствии со статьей 51 Устава Организации Объединенных Наций. Однако данный пункт в Лиссабонском договоре включает разъяснение, что «обязательства и сотрудничество в данной области продолжают соответствовать обязательствам, принятым в рамках Организации Североатлантического Договора, которая для государств, входящих в её состав, остаётся фундаментом их коллективной обороны» ${ }^{220}$.

Пункт о солидарности, в свою очередь, предусматривает, что Евросоюз должен мобилизовать все инструменты, имеющиеся в его распоряжении, включая военные ресурсы, предоставленные государствами-членами, на поддержку того государства-члена, которое стало объектом террористического нападения или жертвой природной или техногенной катастрофы. Эти два положения в совокупности обеспечивают условия для запуска механизма, при котором солидарность с другими государствами-членами в случае военного нападения или массового бедствия становится обязательной и подпадает под юрисдикцию Суда ЕС.

Договорные положения, которые касаются «взаимной помощи» и «солидарности» (статья 222 ДЕС), позволяют предполагать, что в дальнейшем ОПБО может выйти за рамки управления зарубежными (для Евросоюза) кризисами и обрести внутренний с точки зрения Евросоюза план. В среднесрочной перспективе ОПБО может, таким образом, вылиться в более уверенные действия. До сих пор она оставалась инструментом кризисного урегулирования, охватывающего гражданские и военные аспекты, но эксперты не исключают, что в будущем она также будет играть роль в противодействии гибридным угрозам, которые, как считают в самом ЕС, сейчас исходят главным образом от России - в дополнение к первоочередной ответственности НАТО по обороне территории ${ }^{221}$.

Подчеркнём ещё раз, что пока не все положения Лиссабонского договора были полностью имплементированы. Так, ни одна из боевых групп никогда не была задействована

\footnotetext{
${ }^{220}$ Подробнее см.: Хиллион Кристоф, Блокманс Стивен. Самооборона Европы: один за всех и все за одного? // Журнал международного права и международных отношений. 2015 - № 4.URL:

http://www.evolutio.info/content/view/2447/235/

${ }^{221} \mathrm{https}$ ://www.clingendael.nl/sites/default/files/European\%20Strategy\%2C\%20European\%20Defence $\% 20$ and $\% 20$ the $\%$ 20CSDP.pdf.
} 
в операциях Европейского союза 222 . По мнению Ж-К. Юнкера, ситуация нуждается в корректировке: «За последнее десятилетие мы участвовали более чем в 30 гражданских и военных миссиях ЕС от Африки до Афганистана. Однако без постоянной структуры наши действия не будут эффективными. Операции, которые срочно необходимы, откладываются. Параллельные миссии имеют отдельное руководство, даже если они проходят в одной стране или в одном городе. Пора бы нам обзавестись единым командованием для таких операций» $^{223}$.

Средства на ведение ОВПБ, включая гражданские миссии по линии ОПБО, выделяются из наднационального бюджета ЕС, но расходы по военным операциям осуществляются только самими государствами-членами. В этом случае действует, в частности, так называемый Афинский механизм, учрежденный в $2004 r^{224}$. Он позволяет профинансировать сопутствующие общие расходы на транспорт, инфраструктуру, медицинские услуги и прочие общие нужды по таким операциям как «Алтея» в Боснии и Герцеговине, «Аталанта» по борьбе с морским пиратством в районе Африканского рога, тренировочная миссия «Сомали», операция «София» по борьбе с нелегальной переброской беженцев через Средиземное море и тренировочная миссия в Центральноафриканской Республике. Национальные вклады при этом пропорциональны валовому национальному доходу отдельных государств. Кроме того, Лиссабонский договор даёт возможность Совету образовать стартовый фонд из вкладов от государств-членов для быстрого доступа к средствам по финансированию срочных инициатив, которые нельзя поддерживать из бюджета

Евросоюза.

\footnotetext{
222 Подробнее о боевых группах см.: Журкин, там же, С. 165-170.

${ }^{223}$ State of the Union Address 2016: towards a better Europe - a Europe that protects, empowers and defends. Strasbourg, 14 September 2016. URL: http://europa.eu/rapid/press-release_SPEECH-16-3043_en.htm.

${ }^{224}$ Подробнее см.: FACTSHEET. Financing of military operations: the ATHENA mechanism. Brussels, 10 January 2014. URL:

http://www.europarl.europa.eu/meetdocs/2014_2019/documents/sede/dv/sede110914factsheetathena_sede110914facts heetathena_en.pdf;http://www.consilium.europa.eu/en/policies/athena/
} 


\section{Глава 4 МНОГОСТОРОННОСТЬ}

Лиссабонский договор подчеркивает приверженность Европейского союза принципу многосторонности в системе международных отношений. Ключевым аспектом деятельности EC на этом направлении является участие в международных организациях, в выстраивании отношений с которыми он стремится взять на себя роль лидера или, по меньшей мере, задавать тон в работе этих организаций. На деле, интеграционное формирование сталкивается с серьёзными препятствиями, что не позволяет претворить в жизнь явно завышенные амбиции.

Организации, с которыми сотрудничает EC, можно разделить на международные, региональные и неформальные форумы.

Таблица 4-1

Сотрудничество ЕС с международными организациями (выборочно)

\begin{tabular}{|c|c|}
\hline $\begin{array}{c}\text { Тип } \\
\text { международной } \\
\text { организации }\end{array}$ & Наименование организации \\
\hline Глобальные & $\begin{array}{l}\text { Всемирная торговая организация (ВТО) } \\
\text { Организация исламского сотрудничества (ОИС) } \\
\text { Организация Объединённых Наций (ООН) } \\
\text { Организация Объединённых Наций по вопросам образования, } \\
\text { науки и культуры (ЮНЕСКО) } \\
\text { Организация Североатлантического договора (НАТО) } \\
\text { Организация экономического сотрудничества и развития (ОЭСР) }\end{array}$ \\
\hline Региональные & $\begin{array}{l}\text { Андское сообщество } \\
\text { Ассоциация государств Юго-Восточной Азии (АСЕАН) } \\
\text { Африканский союз } \\
\text { Европейская экономическая зона (ЕЭЗ) } \\
\text { МЕРКОСУР } \\
\text { Организация по безопасности и сотрудничеству в Европе (ОБСЕ) } \\
\text { Совет Европы } \\
\text { Совет сотрудничества арабских государств Персидского залива } \\
\text { (ССАПЗ) } \\
\text { Форум «Азия-Европа» (АСЕМ) } \\
\text { Южно-Азиатская ассоциация регионального сотрудничества } \\
\text { (СААРК) }\end{array}$ \\
\hline $\begin{array}{l}\text { Неформальные } \\
\text { форумы }\end{array}$ & $\begin{array}{l}\text { G7/G8 } \\
\text { G20 }\end{array}$ \\
\hline
\end{tabular}

Статус Евросоюза при международных организациях варьируется от полного членства до отсутствия всякого официального статуса. В большинстве случаев ЕС довольствуется неполным членством с разного рода дополнительными возможностями или их полным/неполным отсутствием - в зависимости от конкретной организации. С одной стороны, на положение ЕС в международных организациях влияет распределение полномочий внутри ЕС между институтами и государствами-членами (чем меньше полномочий у институтов, тем ниже соответствующий статус). С другой стороны, в уставах большинства международных организаций определено, что их членами могут быть только государства (в таком случае уровень представительства самого ЕС в международной 
организации зависит от степени политической лояльности к нему руководства этой организации).

На сегодняшний день можно выделить следующие варианты участия ЕС в работе международных организаций.

1) П Полное членство с правом голоса - исключительная ситуация для ЕС. Так, ЕС является полноправным членом ВТО, поскольку международная торговля - это именно та сфера, в которой у него имеются как властные ресурсы, так и большой институциональный потенциал. То же самое относится к статусу ЕС в Продовольственной и сельскохозяйственной организация $\mathrm{OOH}$ (ФАО) и в большинстве международных рыбохозяйственных организаций (например, в Международной комиссии по сохранению атлантических тунцов - ИККАТ, Комиссии по рыболовству в северо-восточной части Атлантического океана -НЕАФК). Однако между членством ЕС в ВТО и ФАО, с одной стороны, и организациях по управлению рыболовством, с другой стороны, есть важное различие: если в первом случае ЕС представлен наряду со своими государствами-членами, то во втором случае параллельное членство отсутствует, то есть ЕС отстаивает интересы сообщества без участия собственных государств-членов (пожалуй, это именно тот максимум, к которому стремится Евросоюз в взаимодействии с международными организациями). При параллельном представительстве ЕС и его государств-членов в одних и тех же организациях между ними нередко возникают споры и разногласия (например, в рамках ФАО), несмотря на разделение компетенций, согласованное специальным заключением Комиссии от 1991 г. (с обновлением на 1994 и 2013 гг.). Более успешным опытом параллельного сосуществования можно считать ВТО: в практике разрешения споров существует только один прецедент, когда страна - участница ЕС подала иск против ЕС и получила удовлетворение - ситуация касалась «рыбных войн» между Союзом и Фарерскими островами 225 .

2) Статус наблюдателя близкий $к$ полному членству, или продвинутый наблюдатель- иллюстрацией в данном случае могут послужить отношения ЕС с ООН (подробнее - см. ниже) и Всемирной таможенной организацией (ВТамО). В последней статус ЕС приближен к полноценному членству, однако для формального обретения оного требуется, чтобы все 172 государства-члена ВТамО приняли соответствующую поправку в его устав, которая позволяла бы экономическим и таможенным союзам присоединяться к Организации наряду с суверенными государствами. Государства-члены ВТамО всячески тормозят вступление ЕС на правах полноценного участника. Поэтому повышение статуса при международных организациях - результат кропотливой и длительной работы представителей единой Европы. Хотя права продвинутого наблюдателя не включают участие в голосовании, в зависимости от конкретной организации, ему могут предоставить такие возможности как выступление на пленарном заседании, участие в рабочих группах, внесение поправок и прочее. Однако далеко не все государства - члены ЕС ратуют за расширение полномочий европейского наднационального формирования в тех международных организациях, членами которых они являются сами.

3) Постоянный наблюдатель - этот статус ЕС имеет, например, при Международной организации труда (МОТ), Всемирной организации здравоохранения (ВО3),

${ }^{225}$ В 2013 г. Дания, действуя от лица автономной провинции Фарерских островов, обратилась в ВТО с запросом о проведении консультаций с ЕС. В запросе Дании указывается, что принятые Евросоюзом меры, запрещающие импорт сельди и скумбрии, выловленной судами Фарерских островов, в страны ЕС, являются дискриминационными и идут вразрез с правилами международной торговли. Это был первый случай, когда страна, будучи членом Союза, инициировала против него разбирательство в международной организации и выступила в роли истца. На уровне ВТО Дания была вынуждена отстаивать позицию Фарерских островов против ЕС, так как Фареры, наряду с Данией, являются членом ВТО с 1995 г., но, будучи автономной провинцией, а не суверенным государством, Фарерские острова все-таки не могут действовать самостоятельно на международном уровне. 
Международном валютном фонде (МВФ) и др. При этом страны ЕС являются полными членами этих организаций, то есть имеет место параллельное представительство. В большинстве случаев, будучи постоянным наблюдателем, Евросоюз всячески пытается повысить свой статус до продвинутого наблюдателя, но удаётся ему это далеко не всегда. Примером такой политической борьбы является Международная морская организация (ИМО), в которой Европейская комиссия (не Сообщество ранее и не Союз теперь) имеет статус наблюдателя с 1974 г. В 2002 г. Комиссия рекомендовала Совету добиваться полного членства в ИМО. Но во время обсуждений в Совете инициатива ЕК наткнулась на сопротивление стран - участниц ЕС. С тех пор статус Комиссии при ИМО остался неизменным. Таким образом, расширению полномочий ЕС в международных организациях противостоят не только третьи страны, но зачастую и сами государства Союза.

4) Отсутствие официального статуса - нередкое для ЕС явление в практике международного сотрудничества. К примеру, несмотря на широкие полномочия и наличие наднационального законодательства в сфере транспорта, ЕС так и не смог получить даже статус наблюдателя при такой влиятельной транспортной организации как Международная организация гражданской авиации (ИКАО). Другим примером является Совет Безопасности $\mathrm{OOH}$, в котором представительство интересов Союза осуществляется посредством странучастниц, согласно ст. 34 ДЕС. Также ЕС пока не удалось стать наблюдателем при Арктическом совете, несмотря на троекратную подачу заявки (подробнее - см. ниже). Частным случаем предстаёт Международное агентство по атомное энергии (МАГАТЭ), где у ЕС нет формального статуса наблюдателя, но при этом соответствующий статус есть у Европейского сообщества по атомной энергетике (Евратом).

Согласно Лиссабонскому договору, представлять ЕС на международной арене могут председатель Европейского совета, председатель Европейской комиссии, Верховный представитель ЕС по иностранным делам и политике безопасности и глава делегации ЕС при ООН.По общему правилу, за исключением вопросов ОПБО и ряда других случаев, предусмотренных учредительными договорами, представительство ЕС в международных организациях обеспечивает Комиссия. На практике это означает, что вопросами европейского взаимодействия на международной арене занимается тот генеральный директорат, чей профиль соответствует тематике данной организации. Верховный представитель по иностранным делам осуществляет внешнее представительство ЕС в вопросах, которые относятся к ОВПБ. На уровне глав государств интересы ЕС представляет председатель Европейского совета, реже -председатель Европейской комиссии, в отдельных случаях - оба (например, на саммитах G20). Разумеется, такое рассредоточение функций представительства вносит неразбериху.

Как мы могли убедиться, важным аспектом участия ЕC в международных организациях являются внутренние правовые вопросы и разделение компетенций между институтами ЕС, с одной стороны, и государствами-членами, с другой. С нормативной точки зрения, договорная основа и правоприменительная практика Суда ЕС поддерживают повышение уровня участие ЕС в международных организациях для осуществления наднациональных полномочий. Сложность заключается в том, что разные направления политики находятся в разных сферах компетенции. Согласно ДФЕС, компетенция Евросоюза подразделяется на три основные категории: исключительная, совместная и вспомогательная.

К первой категории относятся вопросы, решение которых целиком изъято из ведения стран-участниц и передано институтам и органам ЕС: таможенный союз, общая торговая политика, денежно-кредитная политика в пределах еврозоны и др. Во вторую категорию входит подавляющее большинство вопросов, среди которых внутренний рынок, сельское хозяйство и рыболовная политика, охрана окружающей среды, транспорт, энергетика, защита прав потребителя. В этих сферах государства-члены не лишены возможности принимать собственное законодательство на национальном уровне с оговоркой, что данные 
меры не должны противоречить уже действующему европейскому праву, поскольку последнее имеет приоритет.

В 1974 г. Европейскому экономическому сообществу был официально присвоен статус наблюдателя при ООН. Функции представительства ЕЭС в ООН были возложены на Европейскую комиссию. Это был первый случай в истории $\mathrm{OOH}$, когда негосударственное формирование получило статус наблюдателя, наряду с правом участия в Экономическом и социальном совете. Несмотря на то, что полноценное членство в ООН для Евросоюза остается недоступным, - оно предусмотрено только для суверенных государств - это не помешало ЕС подписать более чем 50 многосторонних договоров и конвенций ООН и стать полноценным участником нескольких структур Организации. В 1991 г. ЕС опять-таки стал первой негосударственной структурой, получившей полноценное членство с правом голоса в Продовольственной и сельскохозяйственной организации ООН. Сегодня ЕС осуществляет всеобъемлющее сотрудничество с ООН и её структурами за исключением Совета Безопасности, хотя статья 34 ДЕС предусматривает следующее: «Государства-члены, которые также являются членами Совета Безопасности Организации Объединенных Наций, будут согласовывать свои действия и в полной мере информировать остальные государствачлены, а также Верховного представителя. Государства-члены, которые являются членами Совета Безопасности, при осуществлении своих функций будут защищать позиции и интересы Союза, без ущерба ответственности, возлагаемой на них согласно положениям Устава Организации Объединенных Наций».

Евросоюз сотрудничает с ООН практически по всем направлениям деятельности Организации, включая политику развития, защиту прав человека, экологическую политику, миротворчество, разоружение и нераспространение ядерного оружия, гуманитарная помощь, борьба с коррупцией, управление миграционными потоками и др. ЕС также имеет свои делегации при агентствах и структурах $\mathrm{OOH}$, которые базируются в Женеве, а именно: Совет по правам человека, Управление верховного комиссара $\mathrm{OOH}$ по делам беженцев, Конференция ООН по торговле и развитию, Всемирная организация здравоохранения, Международная организация труда, Конференция по разоружению и Международная организация по миграции.

Стоит также упомянуть о том, что ЕС вместе со своими государствами-членами делают самые крупные взносы на финансирование системы ООН(38\% обычного бюджета Организации, более $40 \%$ бюджета миротворческих операций и более $50 \%$ всех фондов и программ ООН формируются из взносов стран ЕС). Кроме того, ЕК ежегодно тратит из евробюджета 1.35 млрд. долларов на финансирование проектов $\mathrm{OOH}$ по оказанию внешней помощи. ЕС, институты ЕС и страны ЕС, вместе взятые, являются самыми крупными донорами для программ ООН по оказанию гуманитарной помощи и содействию в развитии.

Несмотря на это, для дальнейшего укрепления позиций $\mathrm{EC}$ в системе $\mathrm{OOH}$ существуют достаточно серьезные ограничения. Прежде всего, это связано с государствоцентричной природой ООН, которая практически не оставляет возможности для пересмотра Хартии, предусматривающей членство в Организации только для суверенных государств.

В 2010 г. ЕС внес предложение на обсуждение Генеральной ассамблеи о расширении своего статуса наблюдателя (до полного членства, но без права голоса). Тем не менее, эта инициатива встретила противостояние со стороны нескольких региональных группировок, включая Карибское сообщество и группу стран во главе с Австралией. Спустя год, в результате многочисленных консультаций на международных площадках (между Брюсселем, Женевой и Нью-Йорком) и с третьими странами, Евросоюз добился расширения своего статуса и получил привилегии, какими до этого пользовались только Палестинская автономия и государство Ватикан. Соответствующая Резолюция А/65/276 была принята 3 мая 2011 г. и стала настоящим достижением европейском дипломатической службы и ее главы Кэтрин Эштон, которая хорошо справилась с возложенными на неё функциями 
координатора и переговорщика в деле продвижения этой инициативы. Отныне представители ЕС получили возможность выступать на заседаниях Генеральной Ассамблеи, представляя позиции ЕС как единого актора, а также участвовать в общих дебатах и пользоваться правом незапланированного выступления в ходе заседаний.

Принятие данной резолюции было особенно важно для ЕС. Европейские власти опасались непреднамеренного ослабления позиций единой Европы в $\mathrm{OOH}$ после принятия Лиссабонского договора - в силу того, что Договор отменил ротацию председателей в Совете ЕС по иностранным делам, который ранее поочередно возглавляли страны ЕС, являющиеся полноценными членами $\mathrm{OOH}$, обладающие правом голоса в её руководящих органах и имеющие доступ в комитеты и рабочие группы.

Это была та ниточка, которая связывала Совет ЕС со структурами ООН, поскольку национальные министры иностранных дел, председательствующие в Совете ЕС были важным каналом для донесения позиций ЕС с трибуны ГА. Однако по Лиссабонскому договору, функции постоянного председателя Совета ЕС по иностранным делам были возложены на Верховного представителя, который не имеет собственного доступа в ООН. ЕС это грозило, по меньшей мере, сужением влияния и даже изоляцией, так как возможности для его участия в дебатах были сведены к минимуму ${ }^{226}$. Таким образом, задачей первостепенной важности стало получение права для Верховного представителя выступать перед Генеральной Ассамблеей. Предоставление негосударственному актору возможности участвовать в дебатах демонстрируют не только важность ЕС как международного игрока, но и усиление роли наднациональных формирований в мировой политике в целом.

Впервые перед Генеральной Ассамблеей в новой роли наблюдателя ООН с расширенными полномочиями от лица Евросоюза 22 сентября 2011 г., наряду с главами стран, выступил председатель Европейского совета Херман Ван Ромпёй. Приоритеты ЕС заранее согласовываются странами Союза перед каждой сессией Генеральной ассамблеи и утверждаются Советом ЕС. Важной привилегией, предоставляемой по Резолюции А/65/276, стала возможность для членов делегации ЕС выступать на формальных встречах в ООН, тем самым давая возможность участвовать в процессе переговоров и согласования позиций от начала и до конца. Это гарантирует непрерывность и последовательность в работе делегации, что существенно укрепляет позиции ЕС. Кроме того, делегация ЕС получила право напрямую, а не через делегации стран - участниц ЕС, как это было организовано раньше,распространять среди других делегаций свои письменные послания в качестве официальных документов ООН. ЕС также получил право выступить с ответами на вопросы в ходе завершающего раунда общих дебатов, однако это право ограничено только одним выступлением по каждому пункту повестки дня. Незначительным на первый взгляд, но важным пунктом той же Резолюции стало выделение мест в Генеральной Ассамблее для членов делегации ЕС. Согласно правилам, членам делегации каждой из суверенных стран предоставлено шесть мест, наблюдателям - два места, хотя ЕС сначала пытался добиться для себя выделения шести кресел (гарантированное закрепление кресел за представителями ЕС имеет значение лишь в тех случаях, когда заседания проходят в небольших помещениях).

Вопросы и перспективы взаимодействия с ООН также освещаются в «Глобальной стратегии ЕС по внешней политике и политике безопасности» 2016 г. В Стратегии чётко обозначено стремление ЕС усиливать свои позиции в международных организациях, следуя принципам глобального управления. Также признается необходимость реформирования структуры $\mathrm{OOH}$, включая Совет Безопасности, так как сопротивление переменам в динамично развивающемся мире подтачивает влияние Организации и грозит созданием новых, параллельных группировок в ущерб интересам стран ЕС. В документе сделан акцент

\footnotetext{
226 До принятия этой резолюции представитель ЕС имел право выступить только в конце дебатов и только после получения специального на то разрешения.
} 
на готовности Союза и дальше расширять своё сотрудничество с ООН по линии миротворчества и оказания гуманитарной помощи.

Отношения сотрудничества между Советом Европы (CE) и Европейским экономическим сообществом были установлены еще в 1957 г. Однако первые совместные программы в области защиты прав человека и образования были запущены лишь в 1992 г. Сегодня в основе сотрудничества между двумя организациями лежат принципы и ценности, изложенные в 2006 г. Ж.-К. Юнкером, в то время премьер-министром Люксембурга, которому было поручено вести переговоры с Советом Европы от лица ЕС, в послании о «Едином стремлении Европейского континента» 227.

Евросоюз в своей внешней политике в принципе полагается на стандарты СЕ в отношении фундаментальных прав. Новый этап сотрудничества ЕС и Совета Европы ознаменовало подписание в 2007 г. Меморандума о взаимопонимании ${ }^{228}$. ЕС не имеет формального статуса наблюдателя при Совете Европы, хотя с 1 сентября 2010 г. начала свою работу делегация ЕС при СЕ. Обе организации активно развивают политическое сотрудничество. Начиная с 2012 г., ЕС публикует документы, определяющие приоритеты в сотрудничестве с СЕ. На 2016-2017 гг. в качестве таких приоритетных направлений были выбраны географическое сотрудничество, тематическое сотрудничество (права человека, демократия, верховенство права) и сопутствующие вопросы.

В настоящее время сотрудничество между ЕС и Советом Европы также строится на основе подписанной в апреле 2014 г. «Декларации о намерениях» ${ }^{229}$, которая охватывает страны Восточного партнерства и Южного Средиземноморья. Еще одним важным программным документом является План действий по правам человека и демократии на 2015-2019 гг. Проводятся в жизнь десятки совместных программ, составляющих крупнейший источник финансирования для проектов СЕ по технической помощи и сотрудничеству в поддержку демократических реформ в странах Юго-Восточной и Восточной Европы, Южного Кавказа и Турции. В рамках инициативы ЕС по Восточному партнерству Совет Европы был приглашен к участию в многосторонних платформах по «Демократии, надежному управлению и стабильности» и «Контактам между народами».

По Лиссабонскому договору Евросоюз взял на себя обязательство присоединиться к Европейской конвенции по правам человека Совета Европы, участниками которой уже являются все его государства-члены. В статье 6(2) Лиссабонского договора прямо говорится, что «Союз должен присоединиться (shall accede) к Европейской конвенции по правам человека». Специальные условия такого присоединения оговорены в Протоколе № 8 к Договору. Основным условием стало требование, чтобы в результате присоединения ЕС сохранил свои особые характеристики и правопорядок - иными словами, присоединение Евросоюза к Европейской конвенции по правам человека (далее - Европейская конвенция, Конвенция) не должно затрагивать исключительное право Суда ЕС рассматривать споры между своими государствами-членами по вопросам, касающимся права ЕС. Соответствующее положение закреплено в праве ЕС и действует даже в тех случаях, когда государства-члены являются участниками международных договоров, предполагающих иные механизмы для разрешения споров.

\footnotetext{
${ }^{227}$ Juncker J.-C. A sole Ambition for the European Continent. Report 11.04.2006. 36 p. [Electronic resource]. Mode of access:

https://rm.coe.int/CoERMPublicCommonSearchServices/DisplayDCTMContent?documentId=09000016804e3d96\#sear $\mathrm{ch}=\mathrm{a} \% 20$ sole $\% 20$ ambition.

${ }^{228}$ Memorandum of Understanding between the Council of Europe and the European Union. [Electronic resource]. Mode of access: http://ec.europa.eu/justice/international-relations/files/mou_2007_en.pdf.

${ }^{229}$ Statement of the Intent for the Cooperation Between the Council of Europe and the European Commission. [Electronic resource]. Mode of access: https://rm.coe.int/CoERMPublicCommonSearchServices/DisplayDCTMContent?documentId=090000168066b99e.
} 
Вместе с тем, присоединение ЕС к Европейской конвенции решило бы сразу несколько проблем. Во-первых, оно положило бы конец практике применения двойных стандартов, когда Евросоюз, оставаясь вне рамок данной Конвенции, требует от стран кандидатов на вступление в ЕС обязательного участия в ней. Во-вторых, оно приблизило бы практику Суда ЕС к стандартам Европейской конвенции, то есть к судебной практике Европейского суда по правам человека (ЕСПЧ). К слову сказать, решения Суда ЕС в последнее время стали всё более расходиться с этими стандартами, особенно, когда речь заходит о выдворении за пределы Евросоюза нелегальных иммигрантов, предоставлении убежища и выдаче преступников. Наконец, в-третьих, институты ЕС, которые в настоящее время находятся вне юрисдикции Конвенции, стали бы объектом внешнего (относительно самого Евросоюза) контроля (подразумеваются, например, решения ЕК о наложении штрафов, решения Суда ЕС). Следует отметить, что присоединение ЕС к Конвенции не означало бы, что Евросоюз автоматически сам становится членом Совета Европы.

В апреле 2013 г. представители 47 стран Совета Европы (и Европейского союза) согласовали проект Соглашения о присоединении ЕС к ЕКПЧ. Его проект проходил весьма непростую процедуру согласования. Сначала он(не без осложнений) был утвержден на уровне государств - членов ЕС (в своё время Великобритания выступала с рядом претензий, которые угрожали похоронить Проект). Затем утверждённый проект ратифицировали 47 государств - членов Совета Европы. Далее, согласно статье 218 ДФЕС, Соглашение подлежало утверждению Советом ЕС, причём решение должно быть принято единогласно и только после получения согласия Парламента. Кроме того, Протокол №8 предусматривал обязательное обращение в Суд ЕС для получения заключения о совместимости данного соглашения с учредительными договорами ЕС. После официального обращения Комиссии с запросом дать своё заключение, Суд ЕС провёл двухдневные слушания, где в поддержку проекта Соглашения были представлены мнения Совета ЕС и ЕП. Также в ходе слушаний в той или иной форме Соглашение поддержали 24 государства - члена ЕС.

Однако 18 декабря 2014 года Суд Европейского союза вынес отрицательное Заключение 2/13 по вопросу о соответствии Соглашения о присоединении ЕС к Европейской конвенции о защите прав человека и основных свобод учредительным договорам ЕС, что стало неожиданностью как для государств - членов ЕС, так и для официального Брюсселя. В своём Заключении Суд ЕС подчёркивает, что Конвенция и ее $\square$ судебный механизм создавались для суверенных государств, в то время как ЕС по своей природе государством не является. Как поясняет российский специалист по международному праву А. Исполинов, «свою задачу в данном случае Суд видит в проверке, насколько положения Проекта о присоединении соответствуют положениям учредительных договоров ЕС (их Суд ЕС, кстати, называет конституционной Хартией) и сохраняют особенности правопорядка ЕС и независимость его норм как от национального, так и международного права. Автономный характер правопорядка ЕC требует, чтобы толкование основных прав человека осуществлялось исключительно в рамках институциональной структуры самого Союза» ${ }^{230}$.

В Заключении проанализировано несколько предпосылок для принятого Судом ЕС решения. Одна из них - введение механизма соответчика, позволяющего ЕСПЧ вмешиваться в вопросы распределения компетенции между ЕС и государствами-членами, что на данный момент может делать только Суд ЕС. По сути, этот механизм позволяет ЕСПЧ толковать практику Суда ЕС, с чем последний смириться не готов. Ещё одной предпосылкой для отрицательного заключения по Проекту соглашения стал вопрос о судебном контроле над актами ЕС, принимаемыми в сфере ОВПБ. Сегодня юрисдикция Суда ЕС по данным решениям невелика. Вместе с тем, проект Соглашения позволял толковать его таким

${ }^{230}$ Исполинов А.С. Суд Европейского Союза против присоединения ЕС к Европейской конвенции по правам человека (причины и следствия) // Международное правосудие. 2015. №1. С. 126. 
образом, будто сам ЕСПЧ станет обладать правом судебного контроля над решениями ЕС по вопросам ОВПБ.

Иными словами, для Суда ЕС сама попытка наделить международный суд, находящийся вне институциональной системы ЕС, правом судебного контроля над актами $\mathrm{EC}$, оказалась неприемлемой. Необходимо признать, что суть Заключения сводится к нежеланию Суда ЕС терять свою исключительную компетенцию. А. Исполинов следующим образом трактует мотивацию Суда: «Постоянно расширяя сферу применения Хартии и ставя действия государств ЕС под ее $\square$ контроль, Суд начинает реализовывать свою никак не афишируемую идею судебной федерализации Союза» ${ }^{231}$.

По оценкам наблюдателей, возникшая ситуация не отменяет перспективы присоединения Евросоюза к ЕКПЧ (в конце концов, оно остаётся обязательным по договору), но теперь потребует более существенного времени и усилий для преодоления возникшего препятствия. Весьма вероятным следует считать возобновление переговоров по тексту Соглашения о присоединении ЕС к ЕКПЧ с целью учёта в нём тех озабоченностей, которые выразил Суд ЕС.

С Организацией по безопасности и сотрудничеству в Европе (ОБСЕ) ЕС взаимодействует в сферах предотвращения конфликтов, урегулирования кризисов и демократизации (включая мониторинг выборов). Все страны ЕС являются участниками ОБСЕ, обеспечивая до 70\% бюджета последней, а также значительную часть внебюджетных поступлений и $80 \%$ кадрового состава. Отметим, что по правилам Организации ЕС сам по себе не может быть донором средств в её единый бюджет, поэтому ЕС активно финансирует именно внебюджетные программы и проекты.

ЕС и ОБСЕ преследуют ряд общих целей и интересов, среди которых поддержание мира и безопасности в Европе, предотвращение конфликтов. Обе организации поддерживают постоянный политический диалог, проводятся регулярные встречи (самый высокий уровень - «министерская тройка» ЕС-ОБСЕ). При этом статус ЕС в рамках ОБСЕ формально не определен. По действующим процедурным правилам, Еврокомиссия, входя в делегацию страны-председательницы ЕС, может участвовать в заседаниях органов ОБСЕ при условии, что рассматриваемый вопрос относится к сфере компетенции Евросоюза (по большей части это вопросы, относящиеся к Общей политике безопасности и обороны ЕС). В сферах, которые находятся в исключительной и смешанной компетенции европейского уровня власти, Комиссия может участвовать в дискуссии наравне со странами-участницами ЕС от имени всех стран Евросоюза.

Делегация ЕС в Вене сотрудничает с институтами ОБСЕ на постоянной основе. ЕС имеет своего посла / постоянного представителя, аккредитованного при ОБСЕ. В целом, согласно протоколу, на делегацию ЕС распространяются те же правила и процедуры, что и на делегации отдельных стран. На заседаниях Постоянного совета (где за ЕС зарезервировано отдельное место) Евросоюз обычно выступает с единым заявлением. Отдельные страны-участницы ЕС имеют право на выражение своего несогласия, однако к этой мере они прибегают нечасто. Рабочая группа Совета министров ЕС по ОБСЕ в Брюсселе встречается один раз в месяц, но основную работу выполняют европейские делегации в Вене. В рамках этой работы ЕС постоянно ведет консультации со своими странами-кандидатами, а также с Норвегией, Швейцарией, Канадой. Позиции, с которых ЕС выступает, зачастую обретают поддержку большинства. В саммитах ОБСЕ принимает участие председатель Европейской комиссии, а Верховный представитель ЕС по иностранным делам и политике безопасности - в ежегодной встрече Совета министров иностранных дел.

${ }^{231}$ Исполинов. Там же. С. 129. 
В рамках взаимодействия ЕС с Организацией экономического сотрудничества и развития (ОЭСР), куда входят 35 государств (из них 21 государство ЕС), основной акцент сделан не на выработку обязывающих правил, а на обмен информацией, лучшими практиками и на мягкие формы регулирования. В первую очередь, ОЭСР - это форум, где происходит обмен мнениями и разрабатываются новые подходы по вопросам общей политики. Следует отметить, что ОЭСР сотрудничает еще с 70 странами, которые не входят в число постоянных членов организации. В условиях глобализации и растущей экономической взаимозависимости, такое вовлечение широкого числа участников в диалог делает ОЭСР привлекательной площадкой, где разные страны могут не просто «сверить часы», но и наладить взаимоотношения друг с другом, запустить общие проекты экономического развития. Кроме того, ОЭСР также ежегодно публикует статистические данные и исследования экономических показателей своих стран-участниц, что представляет собой ценный аналитический материал. Организация постоянно принимает открытые многосторонние соглашения, которые в совокупности образуют мягкое право с целью устойчивого экономического роста, финансовой стабильности и открытости мировой экономики.

Штаб-квартира ОЭСР находится в Париже. Как и государства-члены, ЕС имеет при ОЭСР свою постоянную делегацию, в которую, в частности, входит представитель Европейского центрального банка (ЕЦБ) и дипломаты разного уровня и сотрудники Европейской комиссии. В целом, ЕС имеет в ОЭСР «призрачный статус», поскольку, несмотря на то, что глава делегации Евросоюза является членом Совета ОЭСР, он не имеет права голоса при принятии правовых актов. ЕС может голосовать только в Комитете по развитию, где он выступает в качестве дополнительного донора. Представители ЕК и другие сотрудники постоянной делегации заседают в различных специализированных комитетах системы ОЭСР, наряду с национальными представителями. При этом, несмотря на то, что Комиссия зачастую берет на себя лидирующую роль, страны-участницы ЕС по большей части сохраняют право участвовать в обсуждениях.

В целом, ЕС добивается повышения своего статуса в ОЭСР до аналогичного в ВТО или ФАО, то есть полноценное членство с правом голоса. Однако для этого опять-таки необходимо внесение поправок в Устав организации, которые предусматривает членство только для суверенных государств.

Основными методами работы ОЭСР являются диалог, консенсус и взаимоконтроль. В рамках этой международной экономической организации, нацеленной на развитие торговли, статус ЕС выходит за рамки наблюдателя и близок к статусу полноправного участника, однако ЕС не наделен правом голоса при принятии законодательных актов Советом ОЭСР. Вместе с тем, члены делегации ЕС могут быть избраны в качестве членов вспомогательных органов ОЭСР, участвовать в выработке законодательных актов и обсуждении, вносить неограниченное количество поправок. Крупнейшей международной организацией в сфере сотрудничества по валютным и макроэкономическим вопросам является Международный валютный фонд (МВФ) со штаб-квартирой в Вашингтоне. Членами МВФ являются 185 государств, и целью их деятельности является обеспечение стабильности международной валютной системы. Главная задача МВФ - продвижение глобального финансового сотрудничества и международной торговли. МВФ представляет собой классическую международную организацию, которая своими корнями уходит в бреттон-вудскую систему. Соответственно, членами данной организации могут выступать только суверенные государства, поэтому интересы ЕС представляют только страны-участницы. При этом, страны Европы, которые полностью участвуют в Экономическом и валютном союзе (ЭВС), утратили суверенитет в денежно-кредитной сфере, и внешнее представительство Евросоюза в данной области возложено на Европейский центральный банк (ЕЦБ). Тем не менее, в Исполнительном совете МВФ, у ЕЦБ лишь статус наблюдателя. Когда там обсуждаются 
вопросы, касающиеся евро, от лица ЕС заявления делают наблюдатель от ЕЦБ и/или представитель страны ЕС, председательствующей в ЭКОФИН (Совет министров экономики и финансов). Если в ЭКОФИН председатель из страны, не входящей в еврозону, такая задача возлагается на страну зоны евро, которая стоит следующей в списке на председательство.

\section{SWOT-анализ отношений ЕС с МВФ}

\section{Таблица 4-2}

\begin{tabular}{|c|c|}
\hline Сильные стороны & Слабые стороны \\
\hline $\begin{array}{l}\text { - сотрудничество ЕС } \\
\text { с }\end{array}$ & $\begin{array}{l}\text { - тесное сотрудничество ЕС с МВФ в } \\
\text { вопросах преодоления финансового кризиса } \\
\text { (на чём настаивала канцлер Германии } \\
\text { А. Меркель) демонстрирует неуверенность } \\
\text { ЕС в способности самостоятельно решать } \\
\text { свои проблемы; } \\
\text { - работа ЕС с МВФ сопровождается } \\
\text { разногласиями между ответственными } \\
\text { лицами с обеих сторон. }\end{array}$ \\
\hline Возможсности & Угрозы \\
\hline $\begin{array}{l}\text { - сотрудничество с МВФ помогает ЕС } \\
\text { «закрепиться» в качество актора глобального } \\
\text { финансового управления; } \\
\text { - работа с МВФ помогает ЕС перенять } \\
\text { опыт по преодолению кризисов. }\end{array}$ & $\begin{array}{l}\text { - МВФ зачастую подвергает критике за } \\
\text { продвижение «западных интересов»; } \\
\text { - из-за противоречий между ЕС и МВФ, } \\
\text { тесное сотрудничество, продолжавшееся в } \\
\text { 2010-2015 гг. рискует подойти к концу; } \\
\text { - негативная реакция общественности на } \\
\text { программы жёсткой экономии, которые } \\
\text { навязываются МВФ. }\end{array}$ \\
\hline
\end{tabular}

За последние годы МВФ стал для ЕС важным партнёром в деле преодоления финансового кризиса. С одной стороны, совместная работа была определённо полезна обеим организациям, несмотря на возникавшие противоречия входе такого взаимодействия. С другой стороны, опыт работы ЕС с МВФ поставил под вопрос беспристрастность и объективность последней.

Координация позиций отдельных стран ЕС во Всемирном банке (ВБ)менее структурирована. В основе работы Всемирного банка лежит межправительственный принцип. Данная международная организация оказывает помощь в развитии. Европейские представители при ВБ плюс Комиссия в качестве наблюдателя встречаются не менее, чем раз в неделю для обмена информацией и выработки совместных заявлений на основании предложений председательствующей в ЕС страны. Роль ЕС в отношении ВБ в основном состоит в оказании финансовой помощи, чем занимается Европейская комиссия.

Особого рассмотрения заслуживают отношения ЕС со Всемирной торговой организацией (ВТО). ЕС имеет долгую историю членства не только в ВТО, но и в организации ей предшествующей - Генеральном соглашении по тарифам и торговле (ГАТТ). Общая торговая политика находится в сфере исключительной компетенции ЕС, и в данной области ЕС располагает наибольшими властными ресурсами и институциональным потенциалом. В ВТО участвуют все страны ЕС, как и Евросоюз в целом (всего в 
Организации 157 членов). Евросоюз представляет собой третью экономику мира, поэтому в рамках ВТО по праву является одним из ключевых игроков. Интересы Евросоюза в ВТО представляет Европейская комиссия, которая ведет многосторонние переговоры и участвует в разрешении споров с другими участниками.

В отличие от классических международных организаций бреттон-вудской системы, сотрудничество в рамках таких неформальных форумов как «Большая восьмёрка» ${ }^{232}$ и «Большая двадцатка» ${ }^{233}$ предполагает выработку решений, которые не имеют обязательной силы. Эти форумы не обладают правовой базой или постоянно действующими административными структурами. Государства-участники поочередно, в течении года, выполняют на таких встречах-конференциях председательские обязанности, сменяя друг друга в порядке ротации. Тем не менее, им принадлежит важная координирующая роль в глобальном экономическом и финансовом управлении.

«Большая восьмёрка» - это привилегированный клуб, который обсуждает вопросы, относящиеся к ключевым областям компетенции Евросоюза (исключительной, либо совместной с государствами-членами ЕС) и затрагивающие его стратегические интересы. Еврокомиссия и страна-председательница в органах ЕС участвовали от лица Сообщества в заседаниях G7/G8, начиная с 1977 г. (в рамках «семёрки» со времени создания евро ЕК сменили ЕЦБ и Еврогруппа). Но между «восьмёркой» и ЕС нет формальной связи. Отсутствие статуса полного члена «восьмёрки» лишает Евросоюз некоторых привилегий. Так, ЕС не может взять на себя проведение саммита или проявить инициативу в формировании повестки дня. ЕК и председатель Европейского совета пребывают на саммитах G8 как бы в двойном статусе - они представляют как Евросоюз в целом, так и те страны ЕС, которые не входят в «восьмёрку».

В 1999 г. в качестве ещё одного неформального экономического форума была создана «Большая двадцатка», в рамках которой министры финансов и главы центральных банков соответствующих стран обсуждали финансовые вопросы. По мере развертывания глобального финансово-экономического кризиса в рамках G20 проводятся встречи на высшем уровне для координации антикризисной стратегии. Первая из них состоялась в ноябре 2008 г. в Вашингтоне. В 2009 г. «Большая двадцатка» стала главной ареной международной экономической координации, потеснив в этом смысле «семёрку». В G20 полноценно участвуют четыре страны ЕС (Великобритания, Германия, Италия, Франция) и сам Евросоюз, а также присутствуют Испания и Нидерланды, не являющиеся его официальными членами, что позволяет критикам справедливо указывать на то, что представительство интегрированной Европы в «двадцатке» непропорционально велико.

Непосредственное представительство ЕС на саммитах $G 20$ осуществляют совместно председатель Европейского совета (по общим вопросам сотрудничества) и председатель Европейской комиссии (в тех сферах, которые находятся в исключительной компетенции ЕC), в то время как Верховный представитель Союза по иностранным делам представляет EC на министерском уровне на саммитах $G 7$ по вопросах общей политики безопасности и обороны и не входит в состав делегации ЕС на саммитах G20. Вместе с тем, под руководством Верховного представителя Европейская служба внешнеполитических действий осуществляет административную поддержку делегации ЕС во время саммитов. Отсутствие четких правил участия ЕС в «Большой двадцатке» порождает сложности не только для ЕС, но и для международных партнёров, которым приходится мириться с двойным представительством ЕС.

\footnotetext{
${ }^{232}$ Данная группа была сформирована в 1975 г. в качестве группы шести (Великобритания, Германия, Италия, США, Франция, Япония), к которой в 1976 г. присоединилась Канада («семёрка»), а в 1998 г. - Россия («восьмерка»). В 2014 г. лидеры стран «семёрки» приняли решение о приостановке членства России в $G 8$.

${ }^{233}$ Помимо членов G8, включает Аргентину, Австралию, Бразилию, Китай, Индию, Индонезию, Мексику, Саудовскую Аравию, Южную Африку, Южную Корею, Турцию и ЕС.
} 
Несмотря на то, что решения, принимаемые на саммитах $G 20$, носят рекомендательный характер, ЕС является пионером в том, что касается имплементации этих решений. Например, об этом свидетельствует принятие ЕС новых норм финансового регулирования в ответ на глобальный экономический кризис - в подавляющем большинстве эти нормы были основаны на решениях G20. Страны-участницы ЕС, которые не являются членами $G 20$, имеют ограниченные возможности для защиты своих интересов в формате таких саммитов, что стало особенно очевидно в условиях финансового кризиса. Примером этому может послужить ситуация, сложившаяся на саммите $G 20$ в Лондоне в 2009 г., когда Австрия, Бельгия и Люксембург были признаны «налоговыми гаванями», несмотря на принятое до этого решение Европейского совета о том, что ни одной стране ЕС не будет присвоено такое незавидное звание. Вскоре после окончания этого саммита три упомянутые страны довольно резко отреагировали на такое заключение и обвинили европейских партнеров в предательстве их интересов.

SWOT-анализ отношений EC с G20

Таблица 4-3

\begin{tabular}{|c|c|}
\hline ные стороны & Слабые стороны \\
\hline $\begin{array}{l}\text { - G20 служит площадкой для продвижения } \\
\text { европейских норм и стандартов на } \\
\text { глобальном уровне; } \\
\text { - представители стран ЕС имеют } 25 \% \text { мест в } \\
G 20 ; \\
\text { - ЕС является лидером по имплементации } \\
\text { решений } G 20 ; \\
\text { - участвуя в } G 20, \text { ЕС может претворять в } \\
\text { жизнь такие решения, которые встретили бы } \\
\text { протест со стороны отдельных членов ЕС. }\end{array}$ & $\begin{array}{l}\text { - нехватка механизмов для координации ЕС } \\
\text { и стран-участниц ЕС в рамках } G 20 \text {; } \\
\text { - ЕП не может участвовать в координации } \\
\text { позиции ЕC в G20; } \\
\text { - ЕC не входит в список поочередно } \\
\text { председательствующих в } G 20 \text { стран, что не } \\
\text { позволяет ему влиять на повестку дня и } \\
\text { выступать в качестве принимающей стороны; } \\
\text { - слабые механизмы подотчетности. }\end{array}$ \\
\hline Возможнности & \\
\hline $\begin{array}{l}\text { - расширение повестки дня } G 20 \text { позволило } \\
\text { бы ЕС оказывать влияние в большем числе } \\
\text { сфер; } \\
\text { - большая } \\
\text { способствовала } \\
\text { имплетицентации политики ЕС на глозация }\end{array}$ & $\begin{array}{l}\text { - создание коалиций в рамках } G 20 \text { против } \\
\text { ЕС; } \\
\text { - смещение компетенции от институтов } \\
\text { Евросоюза в сторону } G 20 ; \\
\text { - вероятный институциональный конфликт } \\
\text { между ЕС и } G 20 \text { относительно принятия } \\
\text { окончательных решений; } \\
\text { - смещение акцентов в } \\
\text { межправительственного подхода в вопросах } \\
\text { экономического управления. }\end{array}$ \\
\hline
\end{tabular}

Другим примером стала реформа МВФ, в которой непосредственное участие принимали страны «Большой двадцатки». Страны-участницы ЕС, не представленные в G20, были поставлены в известность об изменении в распределении квот МВФ постфактум. Осознав, что решения $G 20$ оказывают на них прямое действие, они стали настаивать на согласовании общей позиции ЕС. Нужно отметить, что до этого позиция ЕС согласовывалась только между Великобританией, Германией, Италией и Францией, являющимися членами G20. Таким образом, начиная с 2010 г., в практику были введены более структурированные механизмы для согласования интересов всех стран ЕС перед саммитами «Большой двадцатки». 
Из проведённого SWOT-анализа (см. таблицу 4-3) следует, что некоторые аспекты взаимоотношений Евросоюза с «Большой двадцаткой» могут быть оценены как положительно, так и отрицательно, в зависимости от конкретной интерпретации и от повестки дня, а также от того, что считать первостепенным - эффективность или подотчетность. Тем не менее, у ЕС явно имеется потенциал для укрепления своих позиций в $G 20$ и, соответственно, на глобальном уровне.

Отношения ЕС с НАТО - отдельная большая тема. На Лиссабонском саммите в ноябре 2010 г. атлантические союзники выразили намерение усовершенствовать стратегическое партнерство по линии НАТО-ЕС. Тем не менее, успешной формализации сотрудничества двух сторон продолжают препятствовать как трансатлантические трения, так и разногласия внутри самого Евросоюза. В натовских кругах никогда не находили нужным поддерживать претензий ЕC на автономную международную роль даже в такой ограниченной области как миротворчество.

В то же время среди членов Евросоюза отсутствует единство в вопросах определения характера основных угроз европейской безопасности, степени независимости ЕС по отношению к США и масштабов будущего европейского военного потенциала. Частично эти вопросы были затронуты в новой «Глобальной стратегии ЕС по внешней политике и политике безопасности», где говорится о необходимости большей автономии ЕС в отношениях с НАТО.

Североатлантический союз является для ЕС не только партнёром, но и конкурентом, что дает о себе знать во взаимоотношениях их бюрократических аппаратов. Каждая из организаций сохраняет свой военный потенциал (хотя они частично пересекаются). Почти одновременно принятые решения о создании боевых групп ЕС (2002 г.) и Сил реагирования НАТО (2003 г.) говорит о низком уровне согласованности их усилий.

В соответствии с договоренностями «Берлин-плюс», зафиксированными в декабре 2002 г., которые вступили в силу в марте 2003 г., Евросоюз получил доступ к коллективным средствам НАТО при проведении своих операций по кризисному управлению, в которых НАТО не участвует. Представители ЕС и НАТО должны регулярно встречаться на уровне министров иностранных дел, послов, высоких военных чинов и советников для обсуждения вопросов, представляющих взаимных интерес. С 2005 г. при Военном штабе появилась натовская постоянная группа связи, в 2006 г. возникла специализированная команда ЕС при Верховном главнокомандовании объединенными вооруженными силами НАТО в Европе.

Но в реальности использование важнейших механизмов «Берлин-плюс» оказалось ограниченным, по сути, двумя миротворческими операциями - «Конкордия» (Македония, 2003 г.) и «Алтея» (Босния и Герцеговина, 2004 г.). Однако в сложных экономических условиях последних лет заинтересованность атлантических партнеров в координации оборонных усилий несколько возросла. Со стороны ЕС об этом свидетельствует шведскогерманская инициатива по развитию военного сотрудничества «Pooling and Sharing» от декабря 2010 г., а со стороны НАТО - инициатива «Умная оборона» от февраля 2011 г. На сегодняшний день у ЕС и НАТО имеется общее понимание основных угроз безопасности в $\mathrm{XXI}$ веке. Подразумевается, что две организации во многом дополняют друг друга своими преимущественно военными (НАТО) и гражданскими (ЕС) возможностями кризисного регулирования. Но на деле в их отношениях немало сложностей, а также элементов соперничества. При этом ЕС в большей мере фокусируется на региональных конфликтах и нестабильности, особенно вблизи собственных границ, а в НАТО больше озабочены транснациональными и технологическими проблемами. В плане оперативного взаимодействия и совершенствования потенциалов связка ЕС и НАТО имеет некоторые достижения и перспективы, но в целом развитие сотрудничества и их практических диалог по-прежнему страдают от нехватки координации и взаимного доверия. 
Взаимодействие Евросоюза с Арктическим советом является примером ситуации, когда ЕС не удаётся получить статус наблюдателя, несмотря на неоднократные попытки. В Арктический совет, созданный в 1996 г. по инициативе Финляндии, входят восемь стран. Пять из них имеют официальный арктический статус - это Дания, Канада, Норвегия, Россия и США. Они уже ведут фактическое экономическое освоение Арктики. Еще три члена Арктического совета - Исландия, Дания, Финляндия - имеют приарктический статус. Иными словами, из всех участников этой организации членами ЕС являются три государства. При этом Норвегия, Исландия и Россия выступают партнёрами ЕС в формате «Северного измерения». Арктический совет представляет собой межправительственный форум высокого уровня, где решения принимаются консенсусом. Входящие в него страны представляют министры иностранных дел на встречах, которые проводятся дважды в год.

Активный интерес к Арктическому совету ЕС начал проявлять с конца 1990-х годов. $\mathrm{C}$ тех пор Евросоюз трижды подавал заявку на получение наблюдательного статуса. Дважды инициатива была заблокирована Канадой и Норвегий из-за запрета, введённого Евросоюзом, на ввоз на его территорию товаров и продукции из тюленей и последовавшего разбирательства по этому вопросу в ВТО. Для обеих стран тюлений промысел имеет важность с исторической и экономической точек зрения. Вдобавок, ЕС конфликтует с Исландией и Данией из-за китобойного промысла, что также затрудняет повышение статуса Брюсселя в Арктическом совете.

На встрече участников организации в Кируне (Швеция) в 2013 г. было принято решение предоставить статус постоянных наблюдателей ряду стран, которые территориально не относятся к Арктике: в том числе Китаю, Индии, Италии, Сингапуру, Японии, Южной Корее и (условно) ЕС. Формально заявка ЕС на получение статуса наблюдателя была рассмотрена положительно, но её имплементацию отложили из-за неурегулированности спора о тюленях. На сегодняшний день ЕС так и не получил искомого статуса при Арктическом совете. Обозреватели сходятся во мнении, что осложнение отношений между Россией и ЕС из-за украинских событий и введения взаимных санкций также же играет не в пользу последнего.

Члены Арктического совета, в особенности пять стран «арктического клуба», выражают обеспокоенность относительно интернационализации арктических дел и растущих политических амбиций ЕС в регионе. В своих документах, посвященных данной тематике, EC на первый план выдвигает вопросы экологии и защиты окружающей среды, всячески подчеркивая, насколько негативно последствия климатических изменений сказываются на европейском регионе. В этом свете ЕС выдвигает себя на роль эксперта по развитию энергосберегающих технологий и сохранению ресурсов Арктики. Таким образом, экологическая составляющая ставится во главу угла аргументации ЕС, однако под «зелёными» декларациями прощупывается твёрдая экономическая почва.

$\mathrm{EC}$, в частности, призывает Международную морскую организацию (в которой ему также не удалось получить статус наблюдателя) ввести запрет на использование тяжелого горючего (мазута) для арктических судов. Он указывает при этом на вредное воздействие такого вида топлива на окружающую среду. Вместе с тем, подобные инициативы скрывают желание ЕС распространить свои нормы и стандарты на судоходство в Арктическом регионе с тем, чтобы в будущем иметь конкурентное преимущество в борьбе за управление регионом и в добыче природных ресурсов.

Следует отметить, что данная инициатива имеет антироссийскую направленность, поскольку именно российские суда, осуществляющие морские перевозки в водах Арктики, как правило, используют недорогое топливо с высоким уровнем содержания серы. В свою очередь, российские порты предоставляют именно этот тип топлива. Как справедливо заключает О.Б. Александров, изменение стандартов и «перевод российских арктических судов с мазута на дизельное топливо приведёт к резкому удорожанию стоимости перевозок и 
сделает российские порты неконкурентоспособными, по сравнению с портами стран ЕС» ${ }^{234}$. Таким образом, интегрированная Европа имеет чётко обозначенный экономикостратегический интерес к региону, но вплоть до настоящего времени встречает отпор от «ключевых» членов Арктического совета, который на данный момент считается главной легитимной организацией, объединяющей страны Арктического региона. Кроме того, отечественные учёные В.Н. Конышев и А.А. Сергунин отмечают, что в борьбе за влияние в Арктике ЕС сталкивается не только с сопротивлением стран - участниц Арктического совета, но и «в обозримом будущем ЕС будет наращивать усилия по расширению своего присутствия в $\mathrm{p}$ егионе и более решительно отстаивать свои права на Арктику. Правда, в отличие от НАТО, США и Норвегии, ЕС будет делать это без заметного акцента на военную силу, предпочитая дипломатические и экономические методы» ${ }^{235}$.

Подводя итог рассмотренным выше аспектам участия ЕС в работе международных организаций, отметим, что на пути к более успешному и эффективному представительству своих интересов ЕС сталкивается с различного рода сложностями: нормативно-правовыми, политическими и внутренними (институционально-организационными). Основным нормативно-правовым препятствием остается тот факт, что большинство современных международных организаций по своей природе тяготеют к бреттон-вудской системе и, с формальной точки зрения, хотят видеть своими членами суверенные государства, а не международные организации или интеграционные формирования, каким является Евросоюз. Отсюда вытекают и политические препятствия: далеко не все державы, проводящие собственный внешнеполитический курс, готовы смириться с усилением экономических блоков и региональных объединений. Данный тезис касается, в том числе, и ряда государств-членов ЕС (Германии, Франции, Великобритании до выхода из Союза), которые не проявляют намерений передавать свои полномочия по работе в международных организациях на наднациональный уровень.

Есть сложности и внутри институциональной структуры ЕС. В изначальном проекте европейских сообществ активное сотрудничество с международными организациями не предполагалось. Поэтому и соответствующие институциональные подразделения появились позже, что стало причиной их фрагментированности сегодня (функции взаимодействия с международными организациями возложены частично на Комиссию, частично на Совет, частично на ЕСВД, а иногда для этого создаются подразделения ad hoc).

В целом, практика представительства в международных организациях в первую очередь даёт понимание внешнеполитических приоритетов ЕС. Во-первых, именно взаимодействие с ООН является для ЕС основой многосторонности. Во-вторых, распределение компетенции между ЕС и странами-участницами в действительности не является решающим фактором в выборе международных организаций для сотрудничества. Вместе с тем, сохраняющаяся неясность относительно полномочий и юридического статуса в ряде случаев порождает сложности не только для ЕС и его членов, но и для третьих стран. Втретьих, становится очевидно, что вопрос о вовлеченности ЕС в работу международных организаций имеет не только юридическую составляющую, но в равной степени, и политическую, и дипломатическую. Факт повышения важности роли ЕС в среде международных организаций нуждается в дальнейшем тщательном осмыслении.

Отметим, что, помимо представительства в международных организациях, ЕС уполномочен вести переговоры о подписании международных соглашений от лица всех государств-членов. Поскольку такие соглашения, в случае подписания, имеют обязательный

\footnotetext{
${ }^{234}$ Александров О.Б. Интересы и приоритеты Арктической стратегии Евросоюза //Вестник МГИМОУниверситета. 2013. № 3 (30). С. 14.

235 Конышев В.Н., Сергунин А.А. Международные организации и сотрудничество в Арктике // Вестник международных организаций. 2011. №3(34). С. 33.
} 
характер для всех стран ЕС (после соответствующей ратификации Европейским парламентом), возникает немало прений в процессе выбора главного переговорщика от ЕС и его команды.

По Лиссабонскому договору, главного переговорщика от ЕС назначает Совет. Вместе с тем, разные государства-члены стремятся заручиться лояльностью главного переговорщика. Иными словами, они хотят видеть на этой позиции своего человека, поэтому очень часто согласование в Совете по этому вопросу носит характер торга, который протекает не всегда гладко. Широко известен, по крайней мере, один случай, когда разногласия относительно фигуры главного переговорщика привели к дипломатическому кризису ${ }^{236}$.

Пытаясь расширить свои полномочия в ряде организацией, ЕС сталкивается со следующими основными сложностями:

1) нормативное ограничение членства только для суверенных государств;

2) нежелание третьих стран видеть увеличение влияния ЕС;

3) нежелание стран-участниц передавать свои компетенции по работе с международными организациями на наднациональный уровень.

Таким образом, несмотря на амбиции в деле расширения участия в глобальном управлении и международных отношениях, ЕС далеко не всегда располагает необходимым политическим потенциалом и ресурсами для того, чтобы поддерживать и расширять своё участие в международных организациях. Ввиду проанализированных выше структурных ограничений Евросоюзу приходится тщательнее отбирать международных партнеров, учитывая юридические, политические и дипломатические аспекты и нюансы такого сотрудничества.

${ }^{236}$ Corthaut T., Van Eeckhoutte D. Legal Aspects of EU Participation in Global Environmental Governance under the UN Umbrella / Ed. by J. Wouters, H. Bruyninckx, S. Basu, S. Schunz / The European Union and Multilateral Governance. 2012. P. 145-170. 


\section{Глава 5 САНКЦИИ}

ЕС применяет санкции, начиная с 1980-х годов. В настоящее время он пользуется ими чрезвычайно широко 237 . Их применение отнесено к сфере ОВПБ. Ключевую роль играет Совет, даже если исполнение соответствующего решения требует прямого вовлечения Комиссии, когда имплементация санкций затрагивает функционирование Единого внутреннего рынка. Лиссабонский договор дополнительно подчеркнул роль Совета в данном отношении. Впрочем, очевидно, что исходное политическое решение всегда поступает от Европейского совета.

Начиная с середины 1990-х годов, ЕС постепенно перешёл от применения всеобъемлющих эмбарго к таргетированным (прицельным), или «продуманным» (smart) санкциям $^{238}$, при использовании которых объектом воздействия считается элита страны, ответственная за шаги и решения, вызвавшие у ЕС неодобрение, а не её население в целом. Прицельные санкции применяются таким образом, чтобы по возможности затрагивать только определённых индивидов, элитные группы и экономические сектора, а не всю экономику страны в целом ${ }^{239}$.

Для имплементации торговых и финансовых санкций Евросоюза требуется регламент Совета. Европейский парламент, с формальной точки зрения, требуется лишь поставить в известность о введении соответствующих мер. Фактически европарламентарии требуют для себя более важной роли. В некоторых случаях ЕП активно выражает своё мнение о достоинствах и недостатках санкционной политики ЕС, призывая к ведению санкций в отношении каких-то стран либо обвиняя исполнительную власть Евросоюза в двойных стандартах ${ }^{240}$.

Запреты на путешествия для физических лиц, как и оружейные эмбарго, обычно не требуют принятия дополнительных (наднациональных) решений (за исключением списков средств двойного назначения - это могут быть, скажем, определённые типы взрывчатых веществ или коммуникационное оборудование).

В принципе санкции могут быть нацелены на изменение поведения объекта, на который они направлены (т.е. действуют в отношении него как орудие принуждения), на ограничение свободы его действий (оказывают сдерживающее влияние) или же с их помощью международные игроки посылают некий сигнал мировому сообществу, другим странам, негосударственным организациям или отдельным лицам. Таким способом санкционирующая сторона может стараться улучшить собственный имидж на международной арене, повысить свою значимость, укрепить некую глобальную норму или продемонстрировать, что кризис, по её представлениям, перешёл на более высокий и опасный уровень дипломатической конфронтации. В конечном счёте, это своеобразная форма (в ряду других существующих форм) для демонстрации экономического и политического влияния в мире.

\footnotetext{
${ }^{237}$ European Union Restrictive measures (sanctions) in force (Regulations based on Article 215 TFEU and Decisions adopted in the framework of the Common Foreign and Security Policy). Updated on 11.10.2016. http://eeas.europa.eu/sites/eeas/files/restrictive_measures-2016-10-11-clean.pdf.

${ }^{238}$ Tostensen A., Bull B. Are Smart Sanctions Feasible? // World Politics. 2002. Vol. 54. № 3. P. 373-403; Portela C. The EU’s Use of ‘Targeted’ Sanctions: Evaluating effectiveness // CEPS Working Document. March 2014. № 391.

239 В узком понимании таргетированные санкции есть те, что затрагивают только индивидов и негосударственных акторов.

${ }^{240}$ Making EU Sanctions More Coherent and Effective. URL: http://www.europarl.europa.eu/sides/getDoc.do?pubRef=//EP//NONSGML+IM-PRESS+20080903IPR36115+0+DOC+PDF+V0//EN\&language=EN .
} 
Если говорить о сигнализирующих санкциях в особенности, то нанесение противной стороне материального ущерба не является их первостепенной целью, хотя они и могут иметь непрямое негативное экономическое воздействие - например, выражаясь в потере прямых иностранных инвестиций в подвергаемой санкциям стране. Таким образом, санкционный инструмент очень важен для ЕС: это одно из ключевых выражений способности его участников коллективно оказывать экономическое и политическое влияние на глобальной арене, демонстрируя союзникам свою надёжность и мировую мощь.

Санкции, применяемые ЕС, во многом выглядят как политическая альтернатива применению военной силы, материальных стимулов и дипломатии в той ситуации, когда нужна какая-то реакция на действия объекта в международной среде, а иного рода действия для Евросоюза затруднены или вовсе недостижимы (в том числе из-за несогласия в рядах государств-членов). Не располагая собственным серьёзным потенциалом военной силы, ЕС в то же время может быть убедительно назван экономической сверхдержавой. Поэтому само по себе применение или угроза применения экономических и финансовых санкций с его стороны весьма внушительны. Экономические санкции могут включать не только торговые эмбарго, но и замораживание активов. Но в международных отношениях в целом возможны и санкции, не имеющие экономического содержания - например, дипломатические.

Санкции сейчас считают в ЕС особенно важным инструментом реагирования на нестабильную ситуацию в сфере безопасности. Рестриктивные меры Евросоюза не имеют прямой экономической мотивации (укрепления экономических позиций Евросоюза). Но в период по завершении холодной войны относительная демилитаризация европейских государств привела к тому, что в разных странах ЕС элиты расходятся в вопросе о желательности и пределах возможного использования военной силы в международных отношениях. Это дополнительно повышает значимость европейских санкций как инструмента по предотвращению конфликтов и реагирования на кризисы, применение которого государства-члены всё же в состоянии согласовать. Растущие угрозы безопасности в мире питают «санкционный инстинкт» Евросоюза. Так, в ситуации с Ираном согласованная европейская поддержка западных санкций дополнительно возросла из-за опасений, что, если ничего не предпринять, то Израиль нанесёт военные удары по иранским ядерным установкам.

Санкции применяются в тех случаях, когда позитивная кондициональность не рассматривается как подходящий или допустимый вариант. Однако действуют санкции только в пределах юрисдикции ЕС, а именно:

- в рамках его территории, включая воздушное пространство;

- по отношению к гражданам ЕС, где бы эти граждане ни находились;

- для компаний и организаций, инкорпорированных в законодательство государствчленов;

- в отношении всякой деловой активности, которая полностью или частично осуществляется в ЕС;

- на борту судов и самолётов, находящихся под юрисдикцией государств-членов.

В Евросоюзе в данной связи особо подчёркивают, что ЕС, в отличие от США, не прибегает к правовым нормам с экстерриториальным применением, что нарушало бы международное право. Санкции «применяются лишь при наличии связи с ЕС: на его территории, в судах и в отношении граждан и юридических лиц государств - членов ЕС, а также бизнеса, ведущегося полностью или частично на территории ЕС» ${ }^{241}$. Но от странкандидатов на членство в объединении, тем не менее, настойчиво ожидают присоединения к его рестриктивным мерам (ситуация с Сербией, которая выразила неготовность присоединяться к санкциям ЕС против России, продемонстрировала, что в правовом плане

241 Дораев М.Г. Экономические санкции в праве США, Европейского союза и России. Москва: Инфотропик Медиа, 2016. С. 109. 
эта претензия со стороны Евросоюза сомнительна ${ }^{242}$ ). Кроме того, хозяйствующие субъекты, заинтересованные в европейских рынках, часто демонстрируют склонность к «добровольному» соблюдению санкций ЕС - в том числе на российской территории ${ }^{243}$.

Здесь мы говорим, главным образом, о санкциях как о «сознательном, происходящем по инициативе власти, отказе (или об угрозе отказа) от установившихся торговых или финансовых отношений» ${ }^{244}$. Санкции ЕС также можно определить как форму негативной обусловленности (в противоположность позитивной обусловленности/кондициональности, о которой мы говорили выше). К ним прибегают, чтобы с помощью угрозы ужесточения наказания побудить некое государство отказаться от каких-то экономических, политических или военных шагов, которых можно от него ожидать. С такой точки зрения, для санкционирующей стороны всегда важно точно обрисовать требования (критерии), которые должны быть выполнены этим государством для прекращения действия санкций. Поскольку санкции являются одной из форм негативной обусловленности, их важной частью выступают требования или критерии, которые должны быть удовлетворены противной стороной, чтобы санкции прекратились. Изменения в её поведении ожидаются вследствие наносимого санкциями материального ущерба, которого противная сторона хотела бы избежать. Иными словами, та страна, на которую направлены санкции, должна представлять себе, что следует сделать, чтобы не усугублять свои потери.

Так, все соглашения ЕС с третьими странами содержат (довольно унизительные для последних) оговорки о временной приостановке их действия в случае нарушения сторонами «существенных условий» договорённости, включая защиту прав человека и демократические принципы, но точные критерии прописаны в них далеко не всегда.

В 2004 г. Совет ЕС очертил общие рамки для принятия санкций в Евросоюзе в соответствующем документе, который был разработан Комитетом по политике и безопасности ${ }^{245}$, где со всей отчётливостью была выражена готовность использовать их в качестве ключевого инструмента во внешней политике Евросоюза. Следующим важным документом стали «Руководящие указания по имплементации и оценке рестриктивных (ограничительных) мер (санкций), принимаемых в рамках Общей внешней политики и политики безопасности ЕС». Его последняя версия была принята Советом в июне 2012 г. $^{246}$. На его основании мониторинг и оценка действия рестриктивных мер ЕС были возложены на Рабочую группу советников по иностранным делам.

Совет ЕС вводит меры сдерживания либо во исполнение резолюций Совета Безопасности ООН (ЕС присоединяется ко всем санкциям, которые вводит Организация Объединённых Наций), либо в конкретных ситуациях он может также усилить ооновские

\footnotetext{
${ }^{242}$ Russia, China Slate EU Sanctions Pressure on Serbia. URL : http://www.balkaninsight.com/en/article/russia-chinacondemn-eu-policy-on-serbia?utm_medium=twitter\&amp\%3Butm_source=twitterfeed.

${ }^{243}$ Дораев М.Г. Там же. С. $158-159$.

${ }^{244}$ HufbauerG. C., SchottJ. J., ElliottK. A. andOeggB. EconomicSanctions Reconsidered, 3rd ed., Washington, D.C.: Peterson Institute for International Economics, 2007. P. 3.

${ }^{245}$ Council of the European Union. Basic Principles on the Use of Restrictive measures (Sanctions). 10198/1/04. Brussels, 2004. [Electronicresource]. $\quad$ Mode access:http://register.consilium.europa.eu/doc/srv?l=EN\&f=ST\%2010198\%202004\%20REV\%201.

${ }^{246}$ Council of the European Union. Guidelines on implementation and evaluation of restrictive measures (sanctions) in the framework of the EU Common Foreign and Security Policy. 11205/12. COR 2. Brussels, 2012. [Electronic resource]. Mode of access: http://data.consilium.europa.eu/doc/document/ST-11205-2012-COR-2/en/pdf.
} 
санкции собственными дополнениями ${ }^{247}$, либо он вводит санкции полностью по своей инициативе (автономно - такие меры особенно уязвимы для критики ${ }^{248}$ ).

В первом случае в качестве примера ооновских санкций, применяемых в ЕС, можно упомянуть рестриктивные меры в отношении Либерии, Анголы, Гвинеи Бисау, Демократической Республики Конго, Центральноафриканской Республики и Южного Судана. Такие санкции встроены в соответствующий санкционный режим, «узаконенный» решением Совета Безопасности ООН и, по крайней мере, в теории имплементируемый всеми государствами - членами ООН. От Евросоюза в данном случае не требуется никаких самостоятельных шагов или инициативы. Речь идёт о санкциях, которые государства ЕС обязаны исполнять сами - как члены ООН. Вмешательство со стороны ЕС обосновывается необходимостью предотвратить разнобой в правилах, действующих на Едином внутреннем рынке, который возникнет, если государства-члены станут вводить санкции поодиночке.

Во втором случае примером могут служить европейские санкции, которые выходят за рамки и пределы, определённые ООН. Иногда их называют «дополнительными» (относительно ооновских санкций). Это санкции ЕС против Ирана, которые вводились с 2010 г., против Корейской Народно-Демократической Республики, против Ливии (2011 г.) и против Кот-д’Ивуара (2011г.). Россия и ряд других стран ставят легитимность подобных «ужесточённых» мер под вопрос ${ }^{249}$.

Санкции ЕС, которые вводились против Сирии, России, Мьянмы, Зимбабве, Беларуси, Китая, Узбекистана и Коморских островов, являются примерами из категории полностью автономных санкций ЕС. Они обычно вводятся в унисон с односторонними санкциями США или других стран и региональных организаций. Именно подобные санкции были подвергнуты последовательной критике Совета ООН по правам человека ${ }^{250}$.

Персональные санкции запрещают занесённым в «черный список» индивидам въезд в EC (выдачу им виз) и замораживают их финансовые активы либо запрещают им иметь банковские счета в странах ЕС. Селективные санкции могут включать частичные эмбарго, запрет на экспорт или импорт определённых товаров - таких как лесоматериалы, нефть, драгоценные камни, какао, оружие или предметы роскоши. Финансовые санкции (запреты на инвестиции и на платежи или замораживание средств государственных компаний), запреты на полёты самолётов тоже относятся к репертуару применяемых селективных санкций. Они могут иметь более широкое воздействие на экономику, нежели персональные санкции. В таргетивные санкции по принципиальным соображениям не попадают продукты питания и медицинские товары (лекарства), чтобы заведомо вывести из-под удара уязвимые социальные группы в тех странах, в отношении которых применяются санкции ЕС.

Экономические и финансовые санкции Евросоюза в функциональном плане можно разделить на три категории ${ }^{251}$.

\footnotetext{
247 Примером здесь могут служить санкции против Ирана. 16 января 2016 г., когда Международное агентство по атомной энергии подтвердило выполнение Ираном соглашения с «шестёркой» (США, Франция, Великобритания, Германия, Китай и Россия) по его ядерной программе, большая часть санкций ЕС и ООН была отменена.

${ }_{248}^{24}$ К автономным санкциям ЕС прибегает, начиная с 1980-х годов. См.: Vines A. The effectiveness of UN and EU sanctions: Lessons for the twenty-first century // International Affairs. 2012. Vol. 88. №. 4. P. 867-877.

${ }_{249}$ См.: Россия выступила против ужесточения санкций в отношении Ирана. 27.09.2010. http://inosmi.ru/asia/20100927/163203979.html.

${ }^{250}$ Совет ООН по правам человека призвал государства не прибегать к односторонним санкциям. 02.10.2015.http://www.un.org/russian/news/story.asp?NewsID=24637\#.WBTwAMkpr1A. См. также: EU sanctions in context: three types by Thomas Biersteker and Clara Portela[Electronic resource]. Mode of access:http://www.iss.europa.eu/uploads/media/Brief_26_EU_sanctions.pdf.

${ }^{251}$ Подробно об этом см.: The EU Sanctions Landscape in 2015: Everything a German Firm Needs to Know. 24 April 2015. URL: http://www.debevoise.com/insights/publications/2015/04/the-eu-sanctions-landscape-in-2015.
} 
- Замораживание активов - наиболее часто используемая ограничительная мера. Она применяется в отношении физических лиц и компаний, определяемых ЕС в соответствии с установленными критериями. Такие меры имеют два практических последствия:

(1) запрещается переводить фонды и экономические ресурсы, принадлежащие соответствующим лицам или компаниям;

(2) запрещается предоставлять им, прямо или косвенно, другие финансовые средства или экономические ресурсы.

У этих ограничений могут возникнуть и некоторые неожиданные результаты: например, списание долга лица из санкционного списка может само по себе составить запрещённое действие. При определённых обстоятельствах есть шанс получить официальное разрешение на ограниченные коммерческие операции с лицом из списка (скажем, если такому лицу нужно осуществить платёж в связи с контрактом, заключённым до того, как это лицо попало под санкции). Такие разрешения обычно выдаются по усмотрению компетентных органов государств-членов ЕС.

- Отраслевые санкции - направленные против целых отраслей хозяйствования, которые могут иметь следующие цели:

(1) помешать стране покупать товары и услуги, которые нужны для продолжения для её действий, которые в ЕС считают противоправными;

2) оказание на такую страну косвенного давления, путём прекращения доступа для игроков её ключевых отраслей к финансовым ресурсам и инвестициям от Евросоюза.

- Запреты на перевод средств.

Европейские меры представляют собой минимальный стандарт, от которого национальные меры по их имплементации могут отличаться, но только в сторону большего ужесточения.

Основанием для наложения автономных ограничительных мер со стороны ЕС служат решения Совета по иностранным делам, которые принимаются единогласно по предложению Верховного представителя Союза по иностранным делам или любого из государств-членов. Некоторые исключения из правила единогласия, применимые в данном случае, предусмотрены параграфом 2 статьи 31 ДЕС (Совет может принять решение и квалифицированным большинством, если имеется предварительное решение Европейского совета на этот счёт либо конкретное предложение Верховного представителя сделано по особому запросу Европейского совета). Здесь в принципе может действовать и механизм конструктивного воздержания, описанный выше. Договор допускает гибкость, позволяющую кому-то из государств-членов не участвовать в принимаемом решении, не блокируя его, что в принципе даёт возможность вводить более жёсткие санкции ${ }^{252}$.

В предварительном порядке предлагаемые меры рассматривают и обсуждают во вспомогательных органах Совета: в рабочей группе Совета, ответственной за регион, к которой относится страна, подвергаемая санкциям; в Рабочей группе советников по иностранным делам; в Комитете по политике и безопасности и в Комитете постоянных представителей на уровне глав постоянных представительств государств-членов ЕС в Брюсселе (COREPERII $\left.{ }^{253}\right)$.

Такое решение Совета является политическим (непосредственно в сфере ОВПБ правовые акты не принимаются). Но оно позволяет принять соответствующий правовой регламент Совета, обязательный для исполнения всеми физическими и юридическими лицами в пределах ЕС. Регламент требуется в случае введения экономических мер, которые относятся к компетенции Союза. Он уже принимается квалифицированным большинством

${ }^{252}$ Blockmans S. Ukraine, Russia and the need for more flexibility in EU foreign policy-making // CEPS Policy Brief. 2014. № 320. URL: https://www.ceps.eu/publications/ukraine-russia-and-need-more-flexibility-eu-foreign-policymaking.

${ }^{253} \mathrm{http}: / /$ www.consilium.europa.eu/en/council-eu/preparatory-bodies/coreper-ii/. 
голосов на основании совместного предложения Верховного представителя и ЕК и вступает в силу на следующий день после публикации в Официальном журнале ЕС. В регламенте обозначены точные пределы вводимых мер, как и детали для их имплементации. Впрочем, зачастую оба документа (и решение, и регламент Совета) принимают одновременно.

Санкции ЕС должны вводиться в действие государствами-членами (в том числе оружейные эмбарго или запреты на поездки ${ }^{254}$ ) и Комиссией - на основании статьи 215 ДФЕС (замораживание активов или экспортные запреты). Формальная роль Европейского парламента, как мы указали, в принятии санкций невелика.

Двухступенчатая процедура, в рамках которой Совет сначала принимает политическое решение, а затем правовой регламент, может порождать сложности с координацией. Но сохранение этой двойственности продиктовано неизменной заботой государств-членов о сохранении суверенитета в том, что касается внешней политики.

Регламенты ЕС, принятые на основании статьи 215 ДФЕС, подлежат контролю со стороны Суда ЕС и Суда общей юрисдикции ЕС. В частности, может быть подан иск с целью их аннулирования (статья 263 ДФЕС). Решения по линии ОВПБ, предполагающие санкции против физических или юридических лиц, тоже подлежат судебному контролю (статья 275 (2)), что является существенным испытанием для санкционного режима ЕС ввиду большого числа выдвигаемых исков.

Для мониторинга применения санкций собираются регулярные встречи Рабочей группы советников по иностранным делам в так называемом «санкционном формате» (RELEX/Sanctions) $^{255}$

Растущее использование санкций, и отраслевых санкций в особенности, возлагает всё более тяжёлое регуляторное бремя на европейские компании. Власти ЕС до сих пор не занимали слишком агрессивной позиции в вопросе о принуждении компаний к исполнению его санкционных правил - в отличие от США, накладывающих штрафы в миллиарды долларов на компании (в том числе некоторые крупнейшие европейские банки и компании), которые попались на несоблюдении американских санкций. Тем не менее, в Германии наказание за нарушение европейского санкционного режима в принципе тоже может предусматривать административные штрафы и даже тюремное заключение.

Теперь проиллюстрируем вышесказанное более предметно на примерах -

(1) антибирманских, (2) антииранских, (3) антисирийских и (4) антироссийских санкциях Евросоюза.

(1) Санкции Евросоюза против Мьянмы были введены в 1991 г. в связи с тем, что высший руководящий орган страны - Государственный совет мира и развития - отказался признать результаты выборов, состоявшихся в 1990 г. За исключением запрета на поставки в страну оружия (который сохраняется до сих пор), они были сняты в 2012 г. после смены политического курса в Мьянме и перехода к демократизации и демилитаризации управления. Режим санкций, продержавшийся 21 год, можно разделить на три этапа, каждый из которых отвечал определённым политическим задачам ЕС.

На первом этапе (с 1991 по 2007 гг.) европейские санкции распространялись на ввоз товаров и сырья из Мьянмы, а также был наложен запрет на въезд в ЕС представителям правящей военной хунты и ряду других лиц, признанных ответственными за репрессии в стране. Цель состояла в изоляции режима военной хунты. Началом второго этапа послужило подавление массовых протестов в Мьянме в 2007 г., на которое ЕС отреагировал

\footnotetext{
254 Запрет на поездку может повлечь за собой отказ в предоставлении визы или недопущение некоего лица через пункт пропуска на территорию ЕС. Обе меры реализуются национальными властями, поскольку ответственность за выдачу виз и осуществление пограничного контроля в ЕС по-прежнему лежит на национальных правительствах.

${ }^{255}$ Дораев. Там же. С. 111. См. также: http://www.consilium.europa.eu/en/council-eu/preparatory-bodies/workingparty-foreign-relations-counsellors/
} 
распространением санкций на поставку в ЕС лесоматериалов, золота, олова, меди, чёрного металла и т.д., а также расширением списка персон non-grata. Таким способом ЕС хотел дополнительно привлечь внимание международной общественности к событиям в Мьянме. Режим санкций продержался вплоть до 2010 г., когда, неожиданно для большинства наблюдателей, правящая хунта взяла курс на проведение либеральных реформ в стране, включая построение открытой экономики и возвращение гражданских партий в политический процесс. Третий этап, длившийся с 2010 по 2012 гг., был отмечен постепенным снятием санкций со стороны $\mathrm{EC}$ с целью поощрения либеральных преобразований, проводимых правительством Мьянмы. Наконец, санкции были сняты после выборов 2012 г. с приходом к власти в стране Национальной лиги за демократию и избранием в депутаты Аун Сан Су Чжи - известной бирманской правозащитницы, долгие годы боровшейся за соблюдение прав человека и демократические преобразования. Вслед за $\mathrm{EC}$, свои антибирманские санкции сняли также США и другие страны запада.

Таким образом, режим санкций был определяющим инструментом во взаимодействии ЕС с Мьянмой на протяжении более двадцати лет. Поставив меры экономического ограничения в прямую зависимость от политических уступок со стороны военной хунты, ЕС тем самым сделал санкции ключевым элементом своего внешнеполитического курса в отношении этой страны, одновременно лишив себя возможности использовать другие инструменты (позитивная кондициональность, социализация), чтобы повлиять на преобразования во внутренней политике Мьянмы.

Если изначально санкции против Мьянмы сопровождались попытками со стороны Брюсселя наладить сотрудничество с этой страной в отдельных сферах, то последовавшие нарушения прав человека вынудили Евросоюз в 1997 г. исключить Мьянму из своей системы торговых преференций - последовало ужесточение санкций. Поступая таким образом, ЕС предполагал не столько нанести экономических урон Мьянме, сколько подать сигнал международному сообществу о преступлениях режима в стране и нарушениях им прав человека. Озабоченность ЕС разделяли США, тогда как попытки убедить членов АСЕАН последовать данному примеру не увенчались успехом. Иными словами, Мьянма так и не оказалась в международной изоляции, а её ВВП продолжал стремительно расти.

Экономический рост Мьянмы в годы действия санкций следует объяснить, прежде всего, тесными торговыми связями со странами Южно-азиатского региона, прежде всего с Китаем, который стал как крупнейшим инвестором и импортёром ресурсов из страны, так и поставщиком ей вооружения. Иными словами, санкции ЕС не столько побудили Мьянму к политическим преобразованиями, сколько подтолкнули к сотрудничеству с более лояльными партнёрами, в результате чего основная цель санкций осталась не достигнутой. Хотя до введения режима санкций Мьянма не была для ЕС приоритетным торговым партнёром, можно справедливо говорить об упущенных возможностях для ЕС - наблюдаемый в последние годы бурный рост торговых оборотов в отношениях ЕС с Китаем и Таиландом вполне закономерно мог бы распространиться и на Мьянму, если бы не действие режима санкций. Что же касается самой Мьянмы, то до прихода к власти военной хунты эта страна и так уже пробыла в международной полуизоляции более тридцати лет, а потому новые санкции со стороны западных стран не были восприняты как нечто неординарное. Более того, игнорируя Мьянму, западные страны сами себя ограничили в рычагах влияния на неё.

Пример Мьянмы показывает, насколько ограниченной может быть эффективность санкций в плане достижения политических целей. Едва ли можно установить прямую связь между началом демократических реформ в Мьянме и санкциями ЕС, которые до этого и так действовали почти двадцать лет. В отношениях с Мьянмой ЕС не удалось разработать более гибкий подход, который разделяло бы международное сообщество и который был бы адекватен меняющейся внутриполитической ситуации в стране. 
(2) Иран скрыл свои планы по обогащению урана и был обвинён международным сообществом в нарушении Договора о нераспространении ядерного оружия 1968 г. Санкции $\mathrm{OOH} \mathrm{против} \mathrm{Ирана} \mathrm{были} \mathrm{введены} \mathrm{в} 2006$ г., когда стало ясно, что Тегеран не намерен сотрудничать с Международным агентством по атомной энергии (МАГАТЭ). Совет ЕС склонен был истолковать указания по резолюции № 1737 СБ ООН от 23 декабря 2006 г. $^{256}$ в расширительном ключе. На протяжении 2000-х годов Евросоюз был самым важным торговым партнёром для Ирана, что давало ему серьёзный рычаг воздействия на поведение Тегерана как международного игрока. Изменение европейского похода, которое произошло в 2010-2011 гг. и выразилось в переходе к широким отраслевым и финансовым санкциям, больно ударившим по иранской экономике, послало политический сигнал иранскому руководству, что тесные торговые связи с Европой не помогут ему добиваться уступок от Запада по ядерному досье.

В 2012 г. Евросоюзом были наложены ограничения на иранские финансовые институты, а также введено нефтяное и газовое эмбарго ${ }^{257}$. С января 2014 г. Совет ЕС временно прекратил действие рестриктивных мер против Ирана, а в январе 2016 г., когда МАГАТЭ подтвердило выполнение Ираном своих обязательств по ограничению ядерной программы согласно Совместному комплексному плану действий, международные санкции против Ирана были отменены.

Нефтяное эмбарго в отношении Ирана, которое ЕС ввёл в июле 2012 г., резко сократило доходы иранского правительства от продажи нефти. Финансовые санкции, включая замораживание счетов многих иранских банков в Европейском союзе и отключение Ирана от системы SWIFT, ограничили доступные для Ирана объёмы иностранной торговли. Всё это сократило для Ирана возможности для манёвра, породив опасения правящего в Тегеране режима, что осложнения в экономических отношениях с ЕС отразятся на внутренней ситуации в стране, спровоцировав социальную и политическую нестабильность. В результате в 2013 г. иранцы вступили в предметные международные переговоры по своему ядерному досье (в существенной части они сделали это, чтобы обеспечить именно отмену европейских санкций).

В 2011 г. ЕС ввёл также санкции против Ирана в связи с нарушением прав человека. Они включают:

- замораживание счетов и запрет на выдачу виз физическим и юридическим лицам, ответственным за серьёзные нарушения прав человека;

- запрет на экспорт в Иран оборудования, которое могло бы использоваться для внутренних репрессий в стране и оборудования для мониторинга телекоммуникаций.

Эти меры регулярно обновляются. Сейчас их действие продлено до 13 апреля 2017 г.

(3) Отношения между Европейским союзом и Сирийской Арабской Республикой регламентируют два основных соглашения, а именно - Соглашение о партнёрстве и сотрудничестве (1977 г.) и Соглашение о стабилизации и ассоциации (2009 г.). До введения антисирийских санкций в 2011 г. ЕС развивал отношения с Сирией в многосторонних рамках как с участницей Евро-средиземноморского партнёрства и Европейской политики соседства. В отношении Сирии, хотя и с ограниченным успехом, применялись разнообразные европейские инструменты, подразумевающие позитивную обусловленность, что имело целью подтолкнуть проведение в стране политических и экономических реформ в западном духе. Но с началом кризиса в 2011 г. ЕС отказался от этих усилий, сосредоточившись взамен

256 Текст резолюции был разработан Великобританией, Францией и Германией, так называемой тройкой Евросоюза, которая до этого три года вела переговоры с Ираном, прерванные в августе 2005 г., в ответ на отказ Ирана прекратить обогащение урана.

${ }^{257}$ Council Decision 35 of 23 January 2012, 2012/35/CFSP. lex.europa.eu/LexUriServ/LexUriServ.do?uri=OJ:L:2012:019:0022:0030:EN:PDF. Подробнее о роли ЕС в решении иранской проблемы см.: Sauer Tom. The EU as a Coercive Diplomatic Actor // The European Union as a Diplomatic Actor / Ed. by Joahim A. Koops and Gjovanni Macaj. Basingstoke, Hampshire, 2015, P. 103-119. 
на применении санкций. Он пошёл на жёсткие политические действия, что по сути лишило его средств позитивного политического влияния на сирийский режим. Напротив, ЕС получил растущую гуманитарную проблему (кризис с беженцами) и угрозу экстремизма на собственной территории.

Антисирийские санкции были введены 9 мая 2011 г. с целью прекратить насилие, практиковавшееся режимом Башара Асада в отношении гражданского населения. Они действуют по сию пору, но с 2011 г. многократно дополнялись. Такие меры включают замораживание активов входящих в «чёрный список» физических лиц и энергетическое эмбарго (в частности, запрет на импорт в ЕС сирийской нефти).

Как следует из подробного сообщения Совета ЕС за 2012 г. $^{258}$, санкции против Сирии охватили целых 17 блоков, в том числе:

- меры против правительства Сирии (главным образом запрет платежей и поддержки со стороны Европейского инвестиционного банка);

- меры против физических лиц, участвовавших в репрессиях (запрет на въезд в ЕС и замораживание активов на территории $\mathrm{EC}^{259}$ );

- меры против репрессивных органов сирийского режима (запрет на передачу оружия и боевой техники);

- меры, направленные против энергетического сектора (запрет на импорт в Европу сирийской нефти и нефтепродуктов);

- меры в торговой области (запрет на грузовые авиаперевозки и на экспорт товаров роскоши - например, из золота и драгоценных металлов).

В 2013 г. Франция и Великобритания настаивали на пересмотре условий оружейного эмбарго, что позволило бы поставку европейских вооружений силам сирийской оппозиции, но достичь консенсуса по этому вопросу не удалось ввиду возражений других государствчленов.

Сирийскому режиму, оказавшемуся под санкциями, удалось впоследствии в какой-то мере перенаправить торговые потоки, главным образом в Ирак и Ливан. До введения антироссийских санкций в 2014 г. он мог также полагаться на российский банковский сектор, чтобы смягчить действие финансовых санкций $\mathrm{EC}^{260}$.

Отметим, что, по оценке наблюдателей, санкционная политика ЕС в отношении Сирии не сопровождалась тщательной оценкой Брюсселем вводившихся (или отменявшихся) им мер ${ }^{261}$, чему препятствовало отсутствие общего понимания среди государств - членов ЕС того, каких целей в общей внешней политике можно таким образом добиться. Как считают Рим Туркмани и Мустафа Хаид, «сирийский кейс показывает, что одними только санкциями нельзя изменить поведение режима и положить конец конфликту. Более того, при столь существенной внешней поддержке, которую имеет Дамаск, санкции скорее поражают гражданское население, а не сирийский режим» ${ }^{262}$.

(4) ЕС ввёл таргетированные санкции против России 31 марта 2014 г. после вхождения Крыма в состав Российской Федерации. Антироссийские санкции ЕС, впоследствии ужесточавшиеся, распадаются на три основных направления. Это

${ }^{258}$ Council of the European Union "The EU and Syria: Fact Sheet”, Press Release, 20 August 2012.

259 На деле соответствующие поставки из европейских стран прекратились в начале 1990-х годов. Главными поставщиками оружия для Сирии выступают Россия и Иран, которые нарастили поставки с 2011 г. В мае 2013 г. Совет ЕС принял решение отказаться от оружейного эмбарго.

${ }^{260}$ Turkmani R., Haid M. The role of the EU in the Syrian conflict. Paper commissioned by the Human Security Study Group. February 2016, London. P. 16. [Electronicresource]. Mode of access: http://www.feslondon.org.uk/cms/files/fes/img/publications/FES_LSE_Syria_Turkmani_Haid_2016\%2002\%2023.pdf.

${ }^{261}$ Giumelli F., Ivan P. The effectiveness of EU sanctions. An analysis of Iran, Belarus, Syria and Myanmar (Burma) // EPC Issue Paper. 2013. № 76. P. 18.

URL: http://www.epc.eu/documents/uploads/pub_3928_epc_issue_paper_76_-_the_effectiveness_of_eu_sanctions.pdf. ${ }^{262}$ Turkmani R., Haid M. P. 18. 
персональные визовые ограничения, экономические санкции, направленные против ряда российских госкомпаний нефтяного, оборонного и финансового секторов, а также ограничительные меры по Крыму. Экономические санкции, в свою очередь, включают четыре важных звена:

- импортное и экспортное эмбарго на торговлю оружием;

- введение ограничений на экспорт в Россию товаров двойного назначения (применяется разрешительный порядок экспорта), а также оказание финансовой и технической помощи, связанной с такими товарами, что затрагивает экспорт из ЕС для девяти российских компаний, включая концерны «Сириус», «Калашников» и ассоциацию «Станкоинструмент»;

- ограничение доступа России к имеющим стратегическое значение технологиям и услугам, которые могут быть использованы для разработки и добычи нефти (такой экспорт подлежит предварительной авторизации со стороны компетентных властей стран - участниц EC, причём в экспортных лицензиях должно быть однозначно отказано, если экспортируемые товары предназначены для разработки и добычи нефти в Арктике, на глубоководном шельфе, а также сланцевой нефти);

- запрет на сделки с акциями и облигациями.

По данным Министерства энергетики России, под запрет попало 68\% оборудования, импортируемого нефтегазовыми компаниями, что может осложнить поддержание темпов добычи ресурсов на истощающихся месторождениях в Западной Сибири ${ }^{263}$. Министерство финансов России оценило потери российской экономики от санкций в 40 млрд. американских долларов в год ${ }^{264}$.

На заседании Европейского совета 19 марта 2015 г. лидеры стран ЕС увязали перспективу прекращения действия отраслевых экономических санкций против России с полным выполнением Минских соглашений ${ }^{265}$. Предусматривалось, что Минские соглашения будут выполнены до 31 декабря 2015 года. Учитывая, что в этот срок уложиться не удалось, Совет ЕС продлил действие секторальных санкций, предусматривающих ограничения финансового и торгового характера, до 31 июля 2016 года. Впоследствии Совет утвердил согласованное Комитетом постоянных представителей (COREPER) очередное продление действия соответствующих мер до 31 января 2017 г., причём три страны (Франция, Великобритания и Швеция) воспользовались процедурой парламентского резерва, при которой страна должна получить одобрение принятого решения в национальном парламенте ${ }^{266}$.

Решением Совета ЕС от 15 сентября 2016 г. антироссийские санкции, введённые в 2014 г. из-за ситуации в Украине, были продлены ещё на шесть месяцев (до 15 марта

2017 г.). К продлению, помимо стран ЕС, присоединились также Черногория, Албания, Лихтенштейн, Норвегия и Украина. Речь в данном случае идёт о так называемом черном списке, в котором 146 человек и 37 организаций. Фигурантам списка запрещен въезд в Евросоюз, а их активы на территории блока заморожены.

263 Удастся ли России обойти запрет на ввоз нефтегазового оборудования с помощью параллельного импорта. 17.07.2015. URL: https:/www.vedomosti.ru/business/articles/2015/07/17/601012-udastsya-li-rossii-oboiti-zapret-navvoz-neftegazovogo-oborudovaniya-s-pomoschyu-parallelnogo-importa.

${ }^{264} \mathrm{http}: / / \mathrm{minfin} . \mathrm{ru} / \mathrm{ru} / \mathrm{press}-\mathrm{center} /$ ?id_4=33013.

265 Комплекс мер по выполнению Минских соглашений (Второе минское соглашение) - документ, согласованный в феврале 2015 г. «нормандской четвёркой» (Германия, Франция, Украина, Россия) и подписанный контактной группой из представителей России, Украины и непризнанных Донецкой и Луганской народных республик, имеющий целью деэскалацию вооружённого конфликта на востоке Украины.

266 Экономические санкции EC в отношении России продлили на полгода. URL: http://www.interfax.ru/business/516470. 
Ограничения на экономические отношения с Крымом и Севастополем (включая запрет на импорт в ЕС товаров, не имеющих украинских сертификатов) продлены до 23 июня 2017 г.

В 2014-2015 гг. звучали предложения отключить Россию от межбанковской системы обмена информацией SWIFT, но в дальнейшем этого не произошло (в 2012 г. такая мера, как мы помним, была применена в отношении Ирана). В России к такой угрозе отнеслись достаточно серьёзно. По мнению представителей экономического блока российского правительства подобные санкции равносильны военным действиям ${ }^{267}$.

Антироссийские санкции Евросоюза противоречат правилам ВТО. На это указывал, в частности, постоянный представитель России при ЕС Владимир Чижов ${ }^{268}$. Однако, в конце концов, Россия приняла решение не обращаться в ВТО по вопросу о западных санкциях, так как данная организация занимается не политическими вопросами, а сугубо экономическими ${ }^{269}$. Оговоримся, что принципы ВТО, конечно, не распространяются на ограничение свободы передвижения физических лиц. Кроме того, в её системе нет общих правил, которые запрещали бы ограничение в обороте капиталов. Но количественные ограничения экспорта и импорта товаров прямо запрещаются статьей ХІ Генерального соглашения по тарифам и торговле ${ }^{270}$.

Между тем предпринятые Евросоюзом меры, чувствительные в экономическом отношении, ограничивают, в частности, доступ к первичному и вторичному рынкам капитала в ЕС для пяти российский финансовых институтов с мажоритарной долей государства в уставном капитале («Сбербанка России», банка ВТБ, «Газпромбанка», «Внешэкономбанка», «Россельхозбанка»), а также для трёх крупных российских энергетических компаний («Роснефть», «Транснефть», «Газпром нефть») и трёх оборонных фирм (ОПК «Оборонпром», «Объединенная авиастроительная корпорация» (ОАК) и НПК «Уралвагонзавод») - и для их дочерних подразделений, в которых эти организации имеют мажоритарную долю.

Кроме того, страны ЕС поддержали приостановку переговоров о членстве России в ОЭСР и двусторонних переговоров ЕС с Россией касательно визовых вопросов и нового базового соглашения. При всём том санкции не коснулись напрямую наиболее чувствительной сферы - российского экспорта нефти, газа и другого сырья.

При единогласной политической поддержке антироссийских мер, некоторые политики высокого уровня из Венгрии, Греции, Италии, Кипра, Словакии и Словении неоднократно высказывали свои сомнения в отношении санкций против Москвы, указывая на их низкое экономическое воздействие и негативные последствия для экономики государств-членов. Как и в прошлом, на эффективности санкционной политики ЕС в данном случае негативно сказывается несовпадение в интересах его участников.

Официальный Берлин взял на себя ключевую роль в принятии и продлении антироссийских санкций, хотя немцам хорошо известно, что всякое наказание для России в Евросоюзе более обременительно как раз для германской экономики, так как существенная часть экспорта ФРГ до сих пор зависела от хороших отношений с Россией. Укажем вместе с тем, что, настаивая на санкциях, правительство Германии категорически отвергло предложения об отправке в Украину оружия и предпочло сосредоточиться на дипломатическом решении данного кризиса.

\footnotetext{
${ }^{267}$ https://www.gazeta.ru/business/2014/09/19/6221773.shtml.

268 Чижов: Санкции ЕС противоречат нормам ВTO, 1 августа 2014. URL: http://vz.ru/news/2014/8/1/698358.html.

269 Russia Rules Out Appealing to WTO Over Western Sanctions. 24 April 2016. URL: https://sputniknews.com/politics/201604221038475089-russia-wont-appeal-wto-sanctions/

${ }^{270}$ Подробнее см.: Гудков Иван. Санкции ЕC в отношении России: неэффективность и незаконность? URL: http://alleuropalux.org/?p=6574.
} 
Санкционные режимы Евросоюза против Мьянмы, Ирана, Сирии и России в целом иллюстрируют его вновь обретенную готовность имплементировать ограничения, направленные против целых отраслей в определённых странах. Нет сомнения в том, что таким образом на эти страны удаётся оказывать существенное давление, хотя точнее оценить эффективность санкций затруднительно. Но эти меры имеют и большой сопутствующий негативный эффект для европейского бизнеса ${ }^{271}$. Можно говорить и о негативных последствиях для Евросоюза и Запада в целом: страны, подвергнутые санкциям, имеют возможность убедиться, сколь опасна может быть для них высокая степень интеграции в глобальную экономику, подчинённую западным правилам.

По статье 215(2) ДФЕС, Суд ЕС вправе проверять законность актов по имплементации мер, согласованных по линии ОВПБ. При этом первичным правом ЕС ограничен тип таких актов. Как следует из статьи 275 ДФЕС, речь в данном случае идёт только о тех решениях, которыми предусматриваются ограничительные меры против физических или юридических лиц. Другие меры ОВПБ (нерестриктивные) не могут стать предметом рассмотрения в Суде.

В статье 263(4) ДФЕС говорится о том, что физическое или юридическое лицо может подавать иски против вторичных актов (исполнительных), адресатом которых оно является, а также против решений, которые непосредственно его затрагивают, но не требуют исполнительных мер. Речь идёт об исках, имеющих целью отмену подобных актов, которые могут быть поданы в течение двух месяцев с момента, когда истец узнал о данном акте. Однако оспаривание рестриктивных мер по линии ОВПБ в рамках преюдициальной процедуры и иски об их незаконности, не говоря уже о требованиях возместить понесённые при их применении убытки, в таких случаях, по мнению большинства компетентных в данном вопросе юристов, не осуществимы ${ }^{272}$. Впрочем, Высокий Суд Лондона в связи с иском «Роснефти» об оспаривании отдельных актов британских властей, принятых во исполнение санкционных актов Совета ЕС, всё же принял решение воспользоваться правом, предусмотренным статьёй 267 ДФЕС, направив в Суд ЕС преюдициальный запрос для получения разъяснений по применению спорных санкционных актов ${ }^{273}$.

Три российских банка (Сбербанк, ВТБ и ВЭБ) подали иски в Суд ЕС после наложения на них европейских санкций. Своё несогласие с процедурой санкций ранее заявила Суду ЕС и российская компания «Роснефть» ${ }^{274}$. Но шансы на успех в подобных делах юристы в целом оценивают не очень высоко. Впрочем, в своё время иранский банк Mellat добился в суде

271 По итогам 2015 года товарооборот между Германией и Россией снизился почти на 24\%, экспорт из Германии - на 25\%. Падение германского экспорта составило почти 7,5 миллиарда евро. Наибольшие потери понесли германские машиностроители и производители сельскохозяйственной продукции. https://rg.ru/2016/06/16/riudiger-fon-frich-dobrym-otnosheniiam-mezhdu-frg-i-rf-alternativy-net.html.

272 Существует, впрочем, и точка зрения о том, что доступные действия в подобных случаях не должны ограничиваться только исками об аннулировании соответствующих актов. См.: Tridimas T., Nebbia P. European Union Law for the Twenty-First Century: Rethinking the New Legal Order. Vol. 1: Constitutional and Public Law. External Relations. Oxford: Hart Publishing, 2004. P. 128.

${ }^{273}$ См.: Войников Вадим, Туркина Анастасия, Мальцева Юлия. Дело НК Роснефть в суде ЕС. 18 марта 2016. URL: http://russiancouncil.ru/inner/?id 4=7405\#top-content.

274 «Роснефть» оспаривает в Суду общей юрисдикции ЕС европейские санкции в отношении нефтяного сектора, которые ограничивают поставки товаров и услуг для использования в арктических, глубоководных и сланцевых поисках и в производстве нефти в России, а также положения о ценных бумагах и кредитовании, ограничивающие предоставление финансирования и услуг по торговле акциями. См.: http://www.interfax.ru/business/510944. См. также: «Роснефть» сильно искует. 18.10.2014. URL: http://kommersant.ru/doc/2593138?utm_source=kommersant\&utm_medium=doc\&utm_campaign=vrez «Роснефть» возражает по порядку ведения. 13 декабря 2014. http://kommersant.ru/doc/2633162?utm_source=kommersant\&utm_medium=doc\&utm_campaign=vrez. 
отмены санкций, наложенных за его предполагаемое участие в иранской ядерной программе, которое не подтвердилось ${ }^{275}$.

Для отмены санкций в судебном порядке нужно доказать отсутствие связи между целью наложения ограничений в отношении конкретных лиц или компаний и содержанием определённой санкции. Так, по иску Mellat суды в Европе пришли к выводу, что не было озвучено достаточных доказательств того, что этот банк поддерживал иранскую ядерную программу. Важны и процедурные вопросы, а также принципы пропорциональности, соразмерности и справедливости ${ }^{276}$. Однако вместе с тем в июле 2015 г. вступили в силу новые процедурные правила (Rules of Procedure ${ }^{277}$ ) для Суда общей юрисдикции EC (General Court), включающие ст. 105, которая регулируют обращение с информацией или материалами конфиденциального характера, имеющими отношение к безопасности ЕС или его государств-членов либо к ведению ими международных отношений. Эта статья в принципе позволяет Суду впредь оценивать закрытую информацию по конкретным делам, касающимся финансовых санкций, избегая при этом донесения определённых данных до физических и юридических лиц, подвергнутых санкциям ЕС и оспаривающим их в судебном порядке. Новые судебные правила снижают шансы на обжалование санкций в будущем.

Такие изменения вызваны тем, что принятие Советом санкционных решений окружено повышенной секретностью, что мешает затем с точностью установить в судебном порядке, действительно ли такие лица виновны в том, в чём их обвиняют, вследствие чего Суд ЕС до сих пор достаточно часто вставал на сторону таких лиц. Например, в широко обсуждавшемся специалистами судебном решении 2008 года по делу саудовского бизнесмена Яссина Кади (Kadi judgment), который оказался в санкционном списке ЕС по запросу Совета Безопасности $\mathrm{OOH}$ в связи с его предполагаемым участием в финансировании ультрарадикальной международной террористической организации «АльКаида» (запрещённой в России), европейские судьи пришли к выводу, что соблюдение прав человека (в частности, его права на доступ к информации, на основании которой он и попал в этот список) важнее общих и туманно сформулированных соображений международной безопасности, и вычеркнули его имя из «чёрного списка».

В сентябре 2014 г. из-за отсутствия убедительных данных в открытом обосновании, представленном Советом, Суд общей юрисдикции ЕС признал неправомерной заморозку активов Центрального банка Ирана. Палестинская группировка «Хамас», признанная в ЕС террористической организацией, тоже выиграла дело по санкциям против Совета в Суде ЕС. Теперь же Суд ЕС вправе в подобных случаях принимать к рассмотрению конфиденциальные аргументы одной из сторон (Совета), не раскрывая их второй стороне процесса (оспаривающим санкции в их отношении лицам и организациям), т.е. проигнорировать собственные обязательства по обеспечению равного доступа состязающихся сторон к материалам дела. По мнению британского адвоката Сароша Зайвалла, который представлял в Суда ЕС интересы иранского банка Mellat, отмеченные нововведения, в свою очередь, тоже могут быть оспорены как нарушающие Европейскую конвенцию по правам человека (хотя подобная практика принята не только в американских судах, но и в британских $)^{278}$.

В том случае, когда регламентом вводятся санкции не против физических или юридических лиц непосредственно, а против отраслей хозяйства, компании, понесшие

\footnotetext{
275 Банк Mellat выиграл судебные иски в Верховном суде Великобритании, в Апелляционном суде по гражданским искам Великобритании и в Суде общей юрисдикции ЕС. Юридические победы не привели к немедленному упрощению деятельности банка за пределами Ирана.

${ }^{276}$ Кондратьева Ирина. Юридический консалтинг под санкциями: как заработать юристам на экономических ограничениях. 28 января 2016. URL: http://pravo.ru/review/view/125692/

277 Содержание документа см. по адресу: http://eur-lex.europa.eu/legal-
} content/EN/TXT/PDF/?uri=OJ:L:2015:105:FULL\&from=EN.

${ }^{278} \mathrm{http}: / /$ www.rbc.ru/politics/13/02/2015/54dcb2f29a794738d6d1220c. 
экономические потери в результате, тоже могут попытаться оспорить санкции, но здесь такая возможность ограничена формулой Плаумана ${ }^{279}$. Они должны подтвердить, что соответствующий правовой акт затрагивает их неким исключительным образом, выделяющим их из общего круга всех прочих лиц ${ }^{280}$.

В настоящее время США и ЕС достаточно плотно координируют свою санкционную политику. Но так было не всегда. Экстерриториальные санкции, накладываемые официальным Вашингтоном на иностранцев за действия, которые они предпринимают вне американской юрисдикции, длительное время служили источником европейскоамериканских споров ${ }^{281}$. В 1996 г. Совет министров ЕС принял регламент ${ }^{282}$ по защите от применения законодательства третьей страны. Он стал важной частью европейских усилий по нейтрализации экстерриториального воздействия на Европу американских экономических санкций того времени. Евросоюз и отдельные государства-члены (начиная с Великобритании) регулярно доводили тогда до Вашингтона своё недовольство и возражения против подобного американского законодательства ${ }^{283}$. Причём в соответствующих американских актах речь шла не о том, чтобы заставить правительства третьих стран предпринять действия против компаний, зарегистрированных в их юрисдикции, и нарушающих условия американских актов.

Оно позволяло американской администрации ограничивать доступ таких компаний на американские рынки и разными косвенными путями мешать их доступу к международным финансовым рынкам. Регламент Совета 2271-96 запретил тогда гражданам или компаниям ЕС подчиняться американским экономическим санкциям, которые излагались в приложении к нему. Тем самым европейские компании и юридические лица, имеющие имущественные интересы в США, в потенциале оказалась подчинены двум наборам законов с противоречащими друг другу требованиями ${ }^{284}$.

Сейчас США обрели новые возможности, чтобы подталкивать Евросоюз к более широкому использованию санкций. Глобализация и рост финансовых рынков, начиная с 1980-х годов, повысили потребность европейского бизнеса, и в особенности банковской отрасли, в постоянном доступе к американским финансовым сетям. В группу стран, представляющих собой наиболее весомую часть иностранного банковского присутствия в

\footnotetext{
${ }^{279}$ Case 25/62 Plaumann v Commission [1963] ECR 95.

280 Лицо считается «напрямую» затронутым соответствующей мерой, если она прямо влияет на его правовое положение и применяется автоматически, без необходимости принятия промежуточных актов. В свою очередь, «индивидуально» затронутым считается лицо, которого соответствующая мера затрагивает «по причине определенных характеристик, особенных для этого лица, или по причине фактической ситуации, которая отличает его от всех других лиц и выделяет его индивидуально таким же образом, как адресата решения». См.: http://alleuropalux.org/?p=6574

${ }^{281}$ Rathbone M., Jeydel P., Lentz A. Sanctions, Sanctions Everywhere: Forging a Path Through Complex Transnational Sanctions Laws // Georgetown Journal of International Law. 2013. Vol. 44. P. 1055-1126.

${ }^{282}$ Речь идёт о таких американских актах, как Cuban Assets Control Regulations 1963, Helms-Burton Act 1996 (закон о контроле и регулировании кубинских активов) и Iran-Libya Sanctions Act 1996, впоследствии Iran Sanctions Act 2006, налагавший финансовые и практические санкции на хозяйствующие субъекты не из США, которые не отказались от торговли с иранской энергетической отраслью. В 2010 г. действие антииранских американских санкций было дополнительно расширено (См. Comprehensive Iran Sanctions, Accountability and Divestment Act 2010). Содержание регламента Совета 1996 г. см.:

Council Regulation (EC) No 2271/96 of 22 November 1996 protecting against the effects of the extra-territorial application of legislation adopted by a third country, and actions based thereon or resulting therefrom Official Journal L 309, 29/11/1996 P. 0001 - 0006. URL:

http://eur-lex.europa.eu/LexUriServ/LexUriServ.do?uri=CELEX:31996R2271:EN:HTML.

${ }^{283}$ Davidson N. U.S. Secondary Sanctions: the U.K. and EU Response// Stetson Law Review. 1998. № 27. P. 14251435.

${ }^{284}$ Подробнее см.: Kern А. Economic Sanctions: Law and Public Policy. London: Palgrave Macmillan, 2009.
} 
США, входят Германия, Франция, Нидерланды и Великобритания ${ }^{285}$. США видят здесь полезный рычаг для продвижения собственных внешнеполитических целей. Соблазнительную «приманку» в виде доступа иностранных банков на собственную территорию Вашингтон использует для того, чтобы сломить и обойти традиционные для европейских правительств сомнения по поводу экстерриториального действия американских санкций $^{286}$.

К примеру, американский закон о санкциях в отношении Российской Федерации (Ukraine Freedom Support Act of 2014), вступивший в силу летом 2015 г., предусматривает, что санкциям может быть подвергнут любой иностранный банк, «сознательно способствовавший осуществлению значительной финансовой трансакции в интересах любого российского лица» из санкционного списка США. Такому иностранному банку может быть запрещено открытие корреспондентского счёта в США, а на уже существующие счета могут накладываться дополнительные ограничения ${ }^{287}$. Угроза применения США вторичных санкций против SWIFT в своё время помогла Вашингтону «убедить» европейцев отключить от системы попавшие в «чёрные списки» 30 иранских финансовых институтов, включая Центральный банк Ирана ${ }^{288}$.

В последние годы США активно пользовались «вторичными» санкциями, которые вводятся против европейских нарушителей согласованных Западом санкций (компаний и индивидов). В качестве примера упомянем Распоряжение № 13645, принятое американской администрацией в июне 2013 г., которое распространило «вторичные» санкции на компании, сотрудничающие с иранской автомобильной отраслью ${ }^{289}$. Его действие было прекращено ещё до конца 2013 г., однако оно вынудило европейских автомобилистов свернуть такое сотрудничество ${ }^{290}$. При этом в Европе имеет широкое распространение (небезосновательная) точка зрения о том, что США используют «вторичные» санкции, чтобы получить рыночное преимущество над конкурентами из третьих стран, начиная с Европы.

Хотя европейские санкции ныне нередко реализуются в координации с Соединёнными Штатами, российский эксперт Мерген Дораев справедливо обращает внимание на то, что внешнюю схожесть санкционных режимов ЕС и Соединённых Штатов не нужно переоценивать ${ }^{291}$. Основные отличия с европейской стороны сводятся к следующему:

- национальная имплементация, которая оставляет больше «лазеек» для нарушителей санкционного режима, нежели в США;

- бюрократизированный процесс принятия решений в Европе (это мешает быстро принимать санкционные решения;

- европейские меры не предусматривают действия за пределами юрисдикции ЕС;

285 Лузанов Андрей. Глава 2: Иностранные банки в США: география глобальной экспансии. URL: https://econ.wikireading.ru/659

${ }^{286}$ Galbert S de. Transatlantic Economic Statecraft. The Challenge to Building a BalancedTransatlantic Sanctions Policy between the United States and the European Union. 2016. P. 5. [Electronic resource]. Mode of access: https://csis-prod.s3.amazonaws.com/s3fs-public/publication/160621_CNASReport_Economic_State.pdf.

287 Усова Елена. США накажут зарубежные банки за работу с РФ. 24.06.2015. http://www.utro.ru/articles/2015/06/24/1247920.shtml.

${ }^{288}$ Gladstone R., Castle S. Global Network Expels as Many as 30 of Iran's Banks in Move to Isolate Its Economy // The New York Times. 15.03.2012. [Electronic resource]. access:http:/www.nytimes.com/2012/03/16/world/middleeast/crucial-communication-network-expelling-iranianbanks.html? r=0.

${ }^{289}$ Executive Order 13645 of June 3, 2013, Authorizing the Implementation of Certain Sanctions Set Forth in the Iran Freedom and Counter-Proliferation Act of 2012 and Additional Sanctions With Respect To Iran // Federal Register / Vol. 78, № 108 / Wednesday, June 5, 2013 / Presidential Documents. P. 33945-33953.

URL: https://www.treasury.gov/resource-center/sanctions/Programs/Documents/13645.pdf.

${ }^{290}$ Galbert Simond de. Op. Cit.

${ }^{291}$ Дораев. Там же. С. 105. 
- в ЕС действует механизм судебного оспаривания введённых санкций.

Поэтому санкционные режимы ЕС и сейчас отличаются меньшей изощрённостью, нежели американские.

Вопрос о санкциях, как уже было сказано, решается единогласно на европейском уровне. Во время переговоров, предшествующих принятию соответствующего решения, европейским правительствам уже нелегко находить общий знаменатель для своих далеко не во всём совпадающих экономических интересов. Затем принятое решение имплементируется и проводится в жизнь государствами-членами на национальном уровне. Например, замораживание счетов оказавшегося под санкциями банка производится национальными властями страны/стран ЕС, где такие счета находятся; национальные власти также отвечают за выдачу лицензий, позволяющих, в порядке исключения, вести такую деятельность, которая общими правилами определённого санкционного режима запрещена.

Иными словами, в силу национальной имплементации в интегрированной Европе возникает известный зазор, позволяющий государствам-членам придерживаться своей интерпретации регламента ЕС. Нюансы национальной имплементации могут вести к более жёсткому или, наоборот, к более снисходительному подходу в различных юрисдикциях.

Евросоюз, со своей стороны, предпринимает некоторые меры, чтобы гармонизировать национальную имплементацию ${ }^{292}$. Но в ЕСВД не хватает для этого кадров. Службе трудно проследить за исполнением и чётким соблюдением европейских решений во всех странах ЕС на национальном уровне или оценить политическое и экономическое воздействие санкционной политики ЕС на третьи страны, юридические и физические лица, против которых они направлены. Нет ясности в вопросе о том, способны ли государства, в случае обнаруженных нарушений санкционного режима, заставить нарушителей вернуться к его соблюдению либо наказать таковых. Государства-члены не склонны выносить вопрос о подобных нарушениях на европейский уровень, поскольку тем самым они обнаруживают свою собственную неспособность проводить в жизнь европейский санкционный режим. Даже когда такая информация становится известна, Европейский союз мало что может сделать. В принципе государство ЕС, нарушающее европейский санкционный режим, можно, конечно, наказать штрафом с подачи Комиссии, но это маловероятно по политическим причинам.

Сложности возникают и на национальном уровне. Национальные агентства и ведомства, занимающиеся вопросами безопасности, больше заинтересованы в максимизации политического эффекта от санкций. В то же время органы экономического и политического профиля стремятся минимизировать негативные экономические последствия для собственных национальных компаний.

В целом санкционная политика Евросоюза, тем не менее, способствует укреплению его роли на глобальной арене, делает его внешнюю политику более заметной, в силу чего нелогично было бы ожидать, что ЕС откажется от применения этой практики в дальнейшем. Расширяется и контекст, в котором могут применяться санкции: сейчас он включает не только защиту прав человека, но также урегулирование кризисов, борьбу с терроризмом и нераспространение оружия массового поражения. В более или менее отдалённом будущем активное оспаривание в судах связанных с санкциями решений ЕС и сложности с их последовательной имплементацией в отдельных странах на его территории, которые были нами отмечены, могут привести к относительному отходу от санкций, адресованных конкретным физическим и юридическим лицам, в пользу более последовательного применения альтернативных - дипломатических или даже силовых мер.

В то же время в обозримой перспективе отказа от упора в политике ЕС на отраслевые санкции, смягчаемые по ходу дела исключениями и изъятиями, скорее всего, не произойдёт,

\footnotetext{
${ }^{292}$ См., например, Council of the European Union. Update of the EU Best Practices for the effective Implementation of restrictive measures. Brussels, 24.06.2015. http://data.consilium.europa.eu/doc/document/ST-10254-2015-INIT/en/pdf.
} 
несмотря на то, что эффективность санкций ставится под вопрос, в том числе и внутри ЕС: «Какие бы негативные представления ни сохранялись в отношении использования санкций, они не отменяют их реальной стратегической значимости и того факта, что санкции пригодятся и в будущем» ${ }^{293}$. Представления о том, что санкции могут или даже непременно должны вести к изменению поведения тех, на кого они нацелены, зачастую не оправдываются. Однако, помимо функции принуждения, они выполняют такие важные во внешней политике ЕС функции как сдерживание и предупреждение. Не следует недооценивать и сигнальную функцию: «Акт наложения санкций воспринимается как сильное ... заявление, что может иметь как внутреннее употребление, будучи нацелено на аудиторию, которая призывает к действиям, так и внешнее, распространяя некий имидж ЕС за рубежом и посылая определённый мэсседж другим акторам» ${ }^{294}$.

Следует согласиться с Франческо Джумелли в том, что «сигнальный аспект определённых санкций не следует низводить до остаточной категории санкций неэффективных» ${ }^{295}$. Ожидаемыми получателями такого сигнала могут быть не только та страна, которая непосредственно подвергается санкциям, но также международное сообщество в целом, некие третьи страны, включая ближайших союзников ЕС, и даже государств-членов. Положительный результат включает проецирование нормативного облика санкционирующей стороны (в данном случае ЕС) в мире.

${ }^{293}$ Giumelli Francesco. How EU Sanctions Work: A New Narrative. Chaillot Papers, May 2013, No 129. P. $41-43$. URL: http://www.iss.europa.eu/uploads/media/Chaillot_129.pdf.

${ }^{294}$ Ibid., P. 10.

${ }^{295}$ Ibid., P. 19. 


\section{ЗАКЛЮЧЕНИЕ}

Термин «внешняя политика» обыкновенно используется для описания того, как государства осуществляют свои взаимоотношения с другими государствами в рамках международной системы. Согласно традиционным представлениям, внешнюю политику ведёт государство, выступающее как единый актор. При этом контроль над формированием и проведением внешнеполитического курса поручают исполнительной ветви национальной власти. К числу главных действующих лиц в сфере внешней политики относятся тогда глава государства/президент, министр иностранных дел/государственный секретарь и министр обороны. Им помогают дипломатическая служба и советники по вопросам внешней политики и безопасности. Судам в таких рамках не отводят ключевой роли.

В условиях после окончания холодной войны масштаб и содержание понятий «внешняя политика» и «дипломатия» значительно расширились. Они имеют теперь отношение ко всем целям, которые государства (или в данном случае региональный блок) рассчитывают достичь в своих отношениях с партнёрами на международной арене. Сегодня внешняя политика включает не только «высокую» политику, но и такие сферы, как экономическая политика, политика развития, международная торговля, как и растущее число внешних аспектов «внутренней» политики - экологической, внутренней безопасности, защиты данных и др. (последние не были непосредственным предметом нашего исследования, хотя расширяющийся масштаб внешней политики неизбежно усугубляет их политизацию).

Дипломатия, понимаемая в узком смысле, осталась неизменной. Она включает формализованные отношения, обычно между государствами, которые ведутся посредством переговоров, ради продвижения государственных интересов и достижения взаимовыгодных результатов. Кроме этого, дипломатия есть метод, каким международные отношения регулируются официальными представителями, которые находятся в столице государства или за рубежом. В таком смысле это слово часто считают синонимом внешних сношений, если таковые подразумевают ведение внешней политики. Но в более широком понимании дипломатия XXI века определяется как процесс коммуникации и репрезентации, имеющий целью налаживание взаимодействия между разными субъектами и индивидами, а не только или исключительно между государствами. Теперь мы часто рассуждаем о коммерческой, экономической, деловой, открытой или превентивной дипломатии.

Сложность с выбором точной аналитической рамки для разъяснения внешней политики ЕС вызвана малой пригодностью для этого традиционных представлений о внешней политике. Чтобы лучше понять смысл внешнеполитических действий Евросоюза, не нужно непосредственно прилагать к нему категории, которые используются при изучении государственной внешней политики. Такой взгляд искажает подлинное состояние дел. Полезнее задаться вопросом, способен ли Евросоюз, как политическая система, в которой принимаются и проводятся в жизнь определённые решения, добиваться собственных целей на международной арене во взаимодействии с другими международными игроками, используя имеющийся в его распоряжении для этого арсенал инструментов. На этот общий вопрос мы даём положительный ответ, который, однако, нуждается в уточнениях.

В настоящей работе выявлена специфика методов проведения Евросоюзом своей политики на международной арене и продемонстрированы инструменты, которыми он при этом пользуется. Можно утверждать, что формы участия Евросоюза в международных делах сильно отличаются от того, как ведут свою внешнюю политику государства. Тем не менее, есть все основания, чтобы считать его международную политику внешней политикой, к тому же достаточно влиятельной - пусть речь и идёт о внешней политике особого рода. Евросоюз поневоле ведёт себя в мировых делах отлично от государств. Смысл данного отличия не в том, что он «добродетельнее» или «альтруистичнее», нежели государства. Есть масса 
аргументов, которые убедительно оспаривают такие утверждения. Суть специфики, его особости также не в том, что внешняя политика Евросоюза является либеральной в нормативном отношении. Суть дела в том, что внешняя политика ЕС реализуется как особый метод управления, принятый и разработанный внутри ЕС, который как бы опрокидывается вовне - в международную среду. Тем, кто не знаком с внутренним управлением ЕС, труднее распознать его действия на международной арене как внешнюю политику.

Она демонстрирует управленческий (governance) подход, который является господствующим внутри $\mathrm{EC}$, а в данном случае предстаёт в его внешнем преломлении. Важное место при этом занимают разные советы сотрудничества министерского уровня, комитеты и подкомитеты, а также транснациональные сети. Это неспешная работа, которая приносит долговременные плоды, но хуже приспособлена для достижения сиюминутных, экстренных, чрезвычайных результатов. В ней даёт о себе знать технократический процесс.

Именно поэтому мы и рассматриваем здесь внешнюю политику Евросоюза во многом как продукт, сформированный его внутренней организацией. Действуя на международной арене, Евросоюз руководствуется теми же принципами, которыми вдохновлялись его собственное создание, развитие и расширение. Квинтэссенция внешней политики Евросоюза особенно ярко проступает в политике соседства, что отнюдь не значит, что именно данное её направление является наиболее успешным. Многие считают как раз, что это не так. Впрочем, такое мнение, зачастую утрированное, может быть во многом продиктовано как раз традиционным взглядом на внешнюю политику.

Глобальное присутствие ЕС, поверх всего прочего, обеспечено его торговой мощью и связями. Это крупнейший в мире рынок и важный (или ключевой) пункт назначения для экспорта многих развивающихся и развитых стран. Слабости же ЕС как внешнеполитического игрока объясняются, прежде всего, отсутствием институциональных или каких-то иных средств, которые помогали бы игрокам, действующим внутри этой системы, добиваться политического согласия между собой по конкретным внешнеполитическим вопросам, вырабатывая однозначные позиции, на реализацию которых Евросоюз мог бы оперативно бросить имеющиеся у него (в потенциале) внушительные средства.

В политической системе Евросоюза, которая лишена последовательной иерархии, европейские институты не способны добиваться общего стратегического видения, которое позволяло бы чётко расставлять приоритеты его глобальной политики. Это такая система внешнеполитического управления, в которой мы наблюдаем не только несколько взаимно налагающихся и пересекающихся политик, у каждой из которых собственная организационная логика, но и обилие институциональных акторов (как институтов ЕС, так и его государств-членов), располагающихся на разных уровнях. В вопросах «высокой» внешней политики компетенция наднациональных институтов остаётся относительно слабой, неразвитой.

Центральная организационная проблема внешней политики Евросоюза заключается в том, что национальные правительства не хотят формально передавать власть в принятии внешнеполитических решений наднациональным институтам. В итоге Евросоюз ограничен в своей способности реагировать на международные кризисы в режиме реального времени. Поэтому для ЕС сейчас вооружённые вмешательства с целью кризисного урегулирования вне его территории фактически не стоят в актуальной повестке дня, хотя отдельные государства-члены (Франция) проводят такие операции самостоятельно.

Таким образом, в ЕС внешняя политика осуществляется по многочисленным каналам, далеко не все из которых находятся под централизованным контролем отдельно взятой исполнительной власти. На протяжении многих лет отдельные подразделения Комиссии отвечали за ведение разных аспектов его внешних сношений - в области международного развития, торговли, рыболовства, защиты окружающей среды - в то время как Совет и позже 
Европейский совет были причастны к «высоким» политическим вопросам международных отношений. В отсутствие центральной исполнительной структуры специфический метод управления внешней политикой работал одновременно как сложноорганизованных и децентрализованный.

Декларируя некие позиции в энергетической политике по отношению к России, по вопросу о вхождении в ЕС Турции или определяя свою роль в ближневосточном урегулировании, европейское объединение и по сию пору не демонстрирует наличия у него общих целей. Большую долю ответственности за это нужно возложить на крупные государства-члены. Так, у Германии до сих пор нет большой склонности к более активным, глобально ориентированным внешнеполитическим действиям. Великобритания, которой не откажешь в наличии такой склонности, по отношению к интеграционному процессу всегда отличалась повышенным скептицизмом. Франция зачастую смотрит на ЕС как на средство поддержать за рубежом свои претензии на национальное величие. Ни у национальных правительств, ни у населения стран ЕС нет развитого понимания роли Евросоюза в мире.

Проведенное исследование позволяет прийти к общему выводу, что Евросоюз присутствует на международной арене в качестве важного действующего лица (в особенности на региональных и глобальных площадках). При этом внешняя политика Евросоюза шире, чем Общая внешняя политика и политика безопасности. Она носит две формы: это коммунитарная внешняя политика (внешние сношения) и ОВПБ («высокая» внешняя политика, которая обеспечивает политическое измерение его внешних сношений). Со временем они довольно тесно переплелись, что особенно ясно просматривается в политике соседства, но различия между ними всё же сохраняются.

Формы присутствия Евросоюза в различных сферах международной и глобальной политики сильно разнятся между собой:

(1) в тех областях, где у ЕС исключительная компетенция (например, международная торговля), внешние визави имеют дело прежде всего с Европейской комиссией, чьи действия подчинены надзору со стороны государств-членов;

(2) в областях смешанной компетенции ЕС могут представлять Комиссия, государство-член, председательствующее в данный момент в Совете министров ЕС, Верховный представитель по иностранным делам и политике безопасности или команда из сотрудников ЕК либо Европейской службы внешнеполитических действий и дипломатов из государств-членов (в зависимости от конкретного вопроса, о котором идёт речь);

(3) в прочих областях, где у ЕС дополнительная (относительно государств-членов) компетенция, или смешанная, но при большой вовлечённости государств-членов (в качестве примера: энергетическая дипломатия) ЕС могут представлять отдельные государства-члены.

Европейский совет определяет тон и задаёт направление внешних действий ЕС, тогда как Совет исполняет его указания - в том, что касается ОВПБ. От Комиссии, как и ранее, исходят инициативы, касающиеся коммунитаризированных областей внешних сношений ЕС (за пределами ОВПБ), но теперь ЕК в большей мере учитывает соображения из области «высокой» внешней политики благодаря той двойной роли, которую играет Верховный представитель, одновременно занимающий пост первого заместителя председателя Еврокомиссии.

Осуществляет внешнюю политику Верховный представитель по иностранным делам и политике безопасности. Экономические стимулы, которые ЕС может использовать в качестве инструментов своего внешнеполитического воздействия на третьих игроков, различаются как позитивные (заключение соглашений о торговле, сотрудничестве или ассоциации, предоставление помощи) и негативные (эмбарго или бойкоты, задержка вступления в силу или прекращение действия соглашений, снижение объёмов помощи, рестриктивные меры). Суд ЕС не имеет юрисдикции в сфере ОВПБ, за исключением: (1) рассмотрения правомерности рестриктивных мер (санкций), которые ЕС реализует против 
конкретных физических и юридических лиц и (2) мониторинга имплементации ОВПБ институтами ЕС. В том, что касается финансирования ОВПБ, то на операции военного и оборонного значения их выделяют государства-члены, а прочие расходы покрываются из бюджета ЕC.

Лиссабонский договор внёс важные изменения в архитектуру Европейского союза и его институтов. Он создал новые структуры для ведения внешней политики Евросоюза (начиная с ЕСВД). Воздействие этих новых структур (как и связанных с ними процессов) остаётся неоднозначным, уровень сложности в его внешнеполитической архитектуре не только не снизился, но, напротив, пожалуй, даже повысился. Поэтому мы можем встретить весьма различающиеся между собой трактовки природы нынешнего внешнеполитического аппарата ЕС, исходящие не только от учёных и журналистов, но даже от практиков внешнеполитической сферы, занимающих высокие посты в ЕСВД или в правительствах государств-членов.

Положения Лиссабонского договора, касающиеся внешней политики, как и было задумано руководством Евросоюза, обеспечили относительно большую скоординированность институциональной структуры его внешней политики. Миссии ЕС, запущенные в последние годы, такие как EUCAP Nestor (Миссия EC по содействию в подготовке региональных сил береговой охраны в районе Африканского Рога и западной части Индийского океана) и EUCAPSAHEL Niger, стартовавшие в 2012 г., показательны в том смысле, что в них, в отличие от миссий прошлых лет, ЕС использует особенно широкий спектр инструментов, сотрудничая как с государствами-членами, так и с внешними акторами (включая ООН и НАТО).

Однако прежняя система опор оставила после себя глубокие следы, она ушла не вполне, что продолжает сказываться на работе задействованных в сфере внешней политики институтов. Европейская служба внешнеполитических действий является мостом между межправительственными институтами (Европейским советом и Советом) и коммунитарными, наднациональными (Комиссией и Парламентом). Более того, она остаётся пространством политической борьбы между двумя обликами Европы и двумя сферами ответственности, которые за ними стоят. Но складывается впечатление, что исход этой борьбы, которая идёт внутри ЕС, уже предопределён (причём в пользу наднациональных институтов).

К основным нововведениям Лиссабонского договора относятся положения, на основании которых учреждена ЕСВД. Весьма высоко оценивается специалистами работа по всему миру 139 делегаций (миссий) ЕС, способных выполнять некоторые из ключевых функций традиционной дипломатии в координации с посольствами государств-членов. Реализация этих новшеств позволила несколько усовершенствовать процессы имплементации внешнеполитических решений, но также привела и к некоторым новым разочарованиям.

Так, было покончено с практикой ротации, когда председательство на встречах министров иностранных дел и во многих рабочих группах Совета по очереди занимали национальные представители, сменяя друг друга каждые полгода. В Совете ЕС по иностранным делам председательское место закреплено за Верховным представителем, вследствие чего его заседания прибавили в плане преемственности и профессионализма, но лишились известной доли амбициозности и напора, которые зависели от национального вклада. Можно констатировать также, что ЕСВД пока не отличается большой эффективностью в координации различных аспектов внешних сношений Евросоюза.

Кэтрин Эштон, которая была Верховным представителем ЕС по иностранным делам с 1 декабря 2009 г. по 1 ноября 2014 г., была занята созданием ЕСВД и потому не в полной мере использовала свою роль как заместителя председателя ЕК для налаживания взаимодействия европейской дипломатической службы с Комиссией. $\mathrm{B}$ Комиссии, 
возглавляемой Жан-Клодом Юнкером, Федерика Могерини, нынешний Верховный представитель, в качестве заместителя главы Комиссии непосредственно курирует такие направления работы ЕК, как внешняя торговля, меры по борьбе с изменением климата и энергетика, гуманитарная помощь и урегулирование кризисов, транспорт, Европейская политика соседства и переговоры по расширению ЕC, сотрудничество в сфере международного развития, миграция в совокупности с внутренними делами и проблемами европейского гражданства, каждое из которых ведёт один из членов Комиссии.

Идея «общей» внешней политики обращена к наличию общих интересов, которые не могут возникнуть автоматически. Интересы Евросоюза в данном случае проистекают из наличия общих ценностей, которые он хочет продвигать и защищать на международной сцене. Таким образом, исходной целью внешней политики ЕС выступает защита европейских ценностей, основополагающих интересов и независимости.

Цели, к которым Евросоюз стремится на международной арене не предполагают завоевания (территорий). Это не есть цели обладания (possession goals), а скорее цели формирования среды (milieu goals), т.е. приспособление под себя и стабилизация окружающей и международной обстановки и условий. В таком ракурсе акцентируется достижение долговременной безопасности, устойчивости, сотрудничества и мира. Цели формирования среды не исключают преследования актором собственных интересов. Однако его интересы не достижимы вне конструктивного взаимодействия с другими акторами. Их невозможно добиваться или самостоятельно обеспечить в одностороннем порядке. В таком случае в качестве инструментов внешней политики Евросоюзу приходится активнее использовать регуляторные механизмы, разного рода соглашения, правовые нормы, что мы особенно наглядно наблюдаем в области проводимой ЕС политики соседства. Помимо традиционных инструментов (диалог, дипломатия, политические и экономические стимулы), здесь важнее выстраивать сети стабильных, институционализированных и устойчивых отношений с другими странами (обществами), организациями и регионами.

Заслуживает специального внимания вопрос о том, как скажется в будущем на внешней политике ЕС перспектива выхода из него Великобритании. С одной стороны, брекзит серьёзно подрывает глобальные позиции Евросоюза, в особенности его способность играть более серьёзную роль в вопросах безопасности, и создаёт дополнительную угрозу шансам на заключение Трансатлантического торгового и инвестиционного партнёрства. C другой стороны, в отсутствие «неуправляемой» Великобритании, принятие согласованных европейских решений во внешней политике ЕС и в глобальном управлении может даже упроститься. Не исключено, что это выльется со временем в появление постоянной структуры оборонного сотрудничества, в котором потенциалы стран - участниц ЕС будут в большей мере объединены, нежели сейчас, и будет наблюдаться большее согласие в вопросах военного планирования. Об этом позволяет судить, в частности, новый план создания европейских структур обороны, представленный в сентябре 2016 г. Федерикой Могерини. За углубление военной интеграции в ЕС, которое прежде тормозило нежелание Великобритании скомпрометировать военное сотрудничество в рамках НАТО, выступают, прежде всего, Италия, Германия и председатель ЕК Ж.-К. Юнкер, а также страны Восточной Европы.

В сентябре 2016 г. министры обороны Франции и Германии Жан-Ив Ле Дриан и Урсула фон дер Ляйен выступили с инициативой обновления общей оборонной политики ЕС, которая была одобрена главами МИД и военных ведомств стран - членов Евросоюза. Она не предполагает появления евроармии, нового штаба или территориальной обороны. Однако, по словам главы Еврокомиссии Юнкера, создание европейской армии неизбежно, так как в долгосрочном плане США откажутся обеспечивать безопасность Европы.

Отметим, что одним из правил традиционной дипломатии является невмешательство во внутренние дела принимающего государства. Но Европейский союз, как мы убедились, 
вмешивается в дела третьих стран в своих внешних сношениях - в особенности это касается стран-кандидатов на членство в ЕС, участников ЕПС и имеющих тесные отношения с Союзом развивающихся стран. Это должно повышать требования к правилам политической отчётности, действующим в отношении его внешней политики. В зависимости от того, кто участвует во внешнеполитических действиях ЕС на конкретном направлении, эти действия должен контролировать Европейский парламент и его комитеты либо контроль должен осуществляться главным образом на уровне парламентов государств-членов, но в настоящее время действующие механизмы контроля не справляются со своей задачей в полном объеме.

Между ЕС как интегрированным объединением и его государствами-членами сохраняется конфликт по поводу акторности на международной арене, поскольку ЕС не получил монополии на представительство собственных интересов в большинстве сфер деятельности, а государства-члены ревностно сохраняют суверенитет в недрах его наднациональной системы. Государства-члены, действуя поодиночке, по-прежнему ведут, пусть в урезанных или остаточных формах, собственный курс в общении с внешним миром, сохраняют национальное представительство в международных организациях. По каждому вопросу в ЕС приходится координировать курсы постоянно, причём возможность одностороннего действия всегда остаётся для государств-членов в запасе. Даже во внешней торговле, где Комиссия убедительно представляет Евросоюз в целом, государства-члены, как мы убедились, непосредственно вовлечены в работу на всех стадиях процесса.

Вступление в силу Лиссабонского договора по времени совпало с мировым финансовым кризисом и кризисом в Еврозоне, которые привели к гораздо более жестким политическим и финансовым условиям, нежели те, в каких ЕС существовал в период выработки договорного текста. Не отразившись на существе внешней политики ЕС, кризис негативно отразился на его способности к коллективным внешнеполитическим действиям. Внимание европейских институтов в большей мере оказалось сосредоточенным на внутренних проблемах - на фоне таких исключительной важности международных событий, как арабская весна 2011 г. и её последствия, в отношении которых ЕС не продемонстрировал слаженной реакции.

Глубокие изъяны Экономического и валютного союза угрожают историческому проекту европейской унификации. Соответствующие вопросы решаются, идёт строительство банковского союза, но экзистенциальные проблемы, переживаемые ЭВС, продолжают отбрасывать мрачную тень на все попытки отладить внешнеполитический механизм ЕС, которые в подобном свете кажутся не столь уж первостепенно важными. Надежда на то, что все проблемы во внешней политике ЕC (связанные с взаимоотношениями между европейскими институтами, между этими институтами и государствами-членами, а также с несогласованностью отдельных её направлений) скоро удастся преодолеть, невелика.

В долговременном плане Европейский союз, как многостороннее региональное объединение, естественным образом нацелен на мировой порядок, который базировался бы на интегрированных регионах и эффективной многосторонности. Неспособность ЕС продвинуться вперёд по пути выстраивания такого мирового порядка грозит ЕС упадком его международной роли и внутренней сплочённости. В центре усилий ЕС по укреплению своего международного влияния лежит стремление к формированию глобального управления. Его внешние связи составляют широкую сеть взаимно накладывающихся друг на друга многосторонних контактов и обязательств с множеством государств, международных организаций и неправительственных акторов. Выступая в качестве глобального игрока, ЕС нацелен на продвижение именно многостороннего мирового порядка.

В начале 2000-х годов в ЕС надеялись, что их модель эффективной многосторонности станет глобальным стандартом, но такие надежды на сегодняшний день не оправдались. На фоне опережающего роста поднимающихся держав, и в первую очередь Китая, и 
наступательного курса России, которая не хочет смириться с периферийной ролью в Европе, где доминируют НАТО и ЕС, глобальный экономический кризис и кризис суверенных долгов в Еврозоне подточили фундамент позиций интегрированной Европы в мире. С тем большим беспокойством европейцы относятся к нарастанию многополюсности в отсутствие работоспособных многосторонних институтов, что способно вести к усугублению внутренних противоречий и расколов в ЕС и к долговременному сокращению его международной роли.

Украинские события и потрясения на Ближнем Востоке и в Северной Африке вывели вопросы мировой политики в верхние строчки повестки дня в Европейском союзе. Но действия Евросоюза на международной арене в последние годы не оправдывают ожиданий, что в обозримой перспективе ему удастся стать одной из крупнейших держав в мировой политике. Погрузившись в борьбу с последствиями мирового финансового кризиса, он, как подтвердили, в частности, события арабской весны в 2011 г., не готов пока встречать международно-политические вызовы во всеоружии.

ЕСВД нередко называют европейским министерством иностранных дел, и ожидания в её отношении, как и критика её действий, обычно продиктованы этой, такой привычной и понятной, рамкой. Действительно, Европейский союз, не будучи государством, до известной степени готов копировать в организации своей внешней политики тот эталон, который задаётся логикой государствоцентризма. Об этом свидетельствует, например, рассмотренная нами структура ЕСВД, в которой, как и в национальных дипломатических службах, сочетаются географические и функциональные департаменты, a также блоки административной поддержки. Дипломаты, которые приходят в ЕСВД из национальных министерств иностранных дел, приносят с собой туда стандартные практики и культуру государственной дипломатии, а также определённые ожидания относительно той роли, которую ЕСВД должна была бы играть. Стремясь обеспечить свою организационную легитимность в качестве новой внешнеполитической службы, ЕСВД в известной мере подвергается внешнему давлению по гомогенизации, принуждающему её соответствовать тем стандартам, которые приняты в глобальном организационном поле традиционной дипломатии. Однако учтём и целый ряд обстоятельств, свидетельствующих о другом.

Структурную дипломатию, опирающуюся на богатые бюрократические и технические возможности Евросоюза, и прежде всего Комиссии, ЕС проводит по отношению к странам участницам по ЕПС, странам АКТ и своим стратегическим партнёрам. Комиссия по существу распоряжается денежными средствами, которые идут на внешнюю политику. Глава ЕСВД является одним из первых заместителей председателя Комиссии. Четыре члена Комиссии нынешнего состава осуществляют политическое руководство генеральными директоратами, действующими в области внешних сношений ЕС. Это Невен Мимица (Neven Mimica), член Комиссии по международному сотрудничеству и развитию, Христос Стилианидис (Christos Stylianides), член Комиссии по гуманитарной помощи и гражданской обороне, Сесилия Мальмстрём, (Cecilia Malmström), член Комиссии ЕС по торговле, и Штефан Фюле (Štefan Füle), член Комиссии по расширению и политике соседства. Они, вместе с Верховным представителем по внешней политике, образуют влиятельную Группу членов Комиссии по внешним сношениям (Commissioners' Group on External Action - CGEA), мандат и состав которой были формализованы в конце 2014 г.

Из бывшего Генерального директората по внешним сношениям (DG RELEX), переданного, как было отмечено выше, в ЕСВД, сотрудники, занимавшиеся вопросами изменения климата и энергетическими проблемами, были заранее переведены во вновь созданный Генеральный директорат по изменению климата (DG CLIMA) и в Генеральный директорат по энергетике (DG ENER). Это сократило самостоятельное влияние Службы в указанных областях, повысив её зависимость от Комиссии. Кроме того, большую часть кадров в зарубежные миссии ЕС направляет вовсе не ЕСВД, а как раз занятые во внешних 
сношениях генеральные директораты Комиссии, которым эти люди непосредственно и подчиняются.

В отношениях со стратегическими партнёрами Евросоюза ЕСВД приходится заниматься сложной «эквилибристикой», одновременно поддерживая претензии национальной дипломатии крупных государств-членов на собственные двусторонние контакты с ними и обеспечивая единые контактные центры для малых государств-членов. В отношениях со стратегическими партнёрами, по крайней мере, крупные государства-члены предпочли бы, чтобы ЕС ограничился только вспомогательной ролью. В то же время ясно, что в политике соседства у ЕС (и ЕСВД) больше оснований для лидерской роли - особенно в отношении тех стран, которые вызывают ограниченный интерес у государств - членов Евросоюза, взятых по отдельности. Совместно государства - члены ЕС способны оказывать в этом плане гораздо большее влияние, чем поодиночке. При этом учтём, что самым важным двигателем в отношениях ЕС с такими стратегическими партнёрами как страны БРИКС или МИНТ (Мексика, Индонезия, Нигерия, Турция) является внешняя торговля, относящаяся к исключительной компетенции Евросоюза.

Необходимо подчеркнуть, что на самом деле дублирование традиционной государственной национальной дипломатии - весьма невыгодная роль для ЕСВД. На этом направлении Служба вступает в конкуренцию с дипломатией ведущих стран ЕС. Победа в такой конкуренции для неё вряд ли достижима. Её главной целью является обеспечение вертикальной и горизонтальной связности во внешней политике ЕС и его государств-членов, а также между отдельными направлениями внешней политики. Чтобы заявить о себе и обеспечить свою выживаемость, Служба должна, напротив, продемонстрировать некое добавленное качество - последовательность, убедительную координацию и институциональную устойчивость во внешнеполитических действиях Евросоюза, для чего ей важно больше ориентироваться на Комиссию как «держательницу» внешнеполитических ресурсов и инструментов. Как указывает, к примеру, Эдвард Бурке, укрепление координирующей роли Верховного представителя по иностранным делам может быть достигнуто путём большей интеграции генерального директората по торговле и ЕСВД.

Сближение ЕСВД с наднациональной Комиссией, сулящее её вынужденный институциональный изоморфизм (растущую схожесть структурных форм) с более мощной организацией, в поле притяжения которой Служба находится, представляется нам определяющим обстоятельством на фоне отмеченного более поверхностного сходства в организации с национальными дипломатическими службами. Такой результат не является сознательным решением разработчиков Лиссабонского договора, где подобная цель не ставилась. Договор призван был повысить степень взаимной увязки различных направлений внешней политики Евросоюза, наладить условия для согласованных коллективных действий в системе принятия и проведения в жизнь внешнеполитических решений европейского уровня, включая элементы взаимодействия с государствами-членами, чего (до известного предела) и удалось добиться.

Однако в то же время то направление, которое обретает на практике развитие ЕСВД, подтверждает «ползучую трансформацию» политического порядка в интегрированной Европе, в котором европейские институты получают возможность постепенно обрести относительную автономию от правительств государств-членов даже без их явно выраженного на то согласия. Оно, в подтверждение наработок организационной теории, может отражать сложившиеся внутри ЕС организационно-архитектурные формы и внутреннюю логику их дальнейшей эволюции. 


\section{ЛИТЕРАТУРА}

Александров О.Б. Интересы и приоритеты Арктической стратегии Евросоюза //Вестник МГИМО-Университета.2013. № 3 (30). C. $12-17 . \quad$ URL: http://www.vestnik.mgimo.ru/sites/default/files/pdf/02mezhd_otn_aleksandrov.pdf[Aleksan drov O.B. Interesy i prioritety Arkticheskoj strategii Evrosojuza [Interests and priorities of the European Union Arctic strategy] // Vestnik MGIMO-Universiteta. 2013. № 3 (30).

S. 12-17].

Андрюшин С.В. Стратегический потенциал Европейского оборонного агентства // Вестник СПбГУ. Сер. 6. 2015. Вып. 1. С. 97-110. URL: http://vestnik.spbu.ru/html15/s06/s06v1/12.pdf [Andrjushin S.V. Strategicheskij potencial Evropejskogo oboronnogo agentstva [The strategic potential of the European defence agency] // Vestnik SPbGU. Ser. 6. 2015. Vyp. 1. S. 97-110].

Баева М.А. Торговые споры в рамках ВТО, в которых участвует Россия, и механизм из разрешения // Российский внешнеэкономический вестник. 2015. № 3. С. 75-90. [Electronic resource]. Mode of access: http://www.rfej.ru/rvv/id/e002c9819/\$file/75-90.pdf [Baeva M.A. Torgovye spory v ramkah VTO, v kotoryh uchastvuet Rossija, i mehanizm iz razreshenija [Trade disputes in the WTO with Russian participation and the mechanism of their settloement] // Rossijskij vneshnejekonomicheskij vestnik. 2015. № 3. S. 75-90].

Болгова И.В. Политика ЕС В Закавказье и Центральной Азии. Истоки и становление. М.: Навона, 2008 [Bolgova I.V. Politika ES V Zakavkaz'e i Central'noj Azii. Istoki i stanovlenie [Policy of the EU in Transcaucasus and Central Asia]. M.: Navona, 2008].

Борко Ю.А. Россия - Евросоюз: состоялось ли стратегическое партнёрство? // Современная Eвpona. 2014. №33. C. 4-8 [Borko Ju.A. Rossija - Evrosojuz: sostojalos' li strategicheskoe partnjorstvo? [Russia - the European Union: has the strategic partnership been achieved?]// Sovremennaja Evropa. 2014. №33. S. 4-8].

Борко Ю.А. Россия - Евросоюз: от стратегического партнёрства к холодному миру // Европейская безопасность: события, оценки, прогнозы. 2013. №30. С. 4-10 [Borko Ju.A. Rossija - Evrosojuz: ot strategicheskogo partnjorstva k holodnomu miru [Russia - the European Union: from strategic partnership to cold peace] // Evropejskaja bezopasnost': sobytija, ocenki, prognozy. 2013. №30. S. 4-10].

Борко Ю.А. Евросоюз как институциональная система // Мир перемен. 2011. № 2. С. 186-189. [Borko Ju.A. Evrosojuz kak institucional'naja sistema [European Union as an Institutional System] // Mir peremen. 2011. № 2, S. 186-189].

Борко Ю.А. Взаимосвязь процессов расширения и углубления европейской интеграции // Расширение Европейского Союза и Россия. М., 2006 [Borko Ju.A. Vzaimosvjaz' processov rasshirenija i uglublenija evropejskoj integracii; Rossija - Evropejskij Sojuz: scenarii vzaimootnoshenij [The interplay of enlargement and deepening in European integration] // Rasshirenie Evropejskogo Sojuza i Rossija. M., 2006].

Восточное партнёрство до и после Вильнюса // Доклады Института Европы. М.: ИнститутЕвропыРАН, 2014. № 301. 94 с. [Vostochnoe partnjorstvo do i posle Vil'njusa [Eastern partnership before and after Vilnius] // Doklady Instituta Evropy. M.: Institut Evropy RAN, 2014. № 301. 94 s.].

Димаджио Пол Дж., Пауэлл Уолтер В. Новый взгляд на «железную клетку»: институциональный изоморфизм и коллективная рациональность в организационных полях // Экономическая сочииология. Т.11. №1. Январь 2010. С. 34-56 [DimadzhioPolDzh., Paujell Uolter V. Novyjvzgljadna «zheleznujukletku»: institucional'nyjizomorfizm i kollektivnaja racional'nost' $\mathrm{v}$ organizacionnyh poljah [The iron cage revisited": institutional isomorphism and collective rationality in organizational fields] // Jekonomicheskaja sociologija. 2010. T.11. №1, S. 34-56]. 
Дораев М.Г. Экономические санкции в праве США, Европейского союза и России. Москва: Инфотропик Медиа, 2016.

Европейский Союз в XXI веке: время испытаний / Под ред. О.Ю. Потёмкиной (отв. ред.), Н.Ю. Кавешникова, Н.Б. Кодратьевой. М.: Весь мир, 2012 [Evropejskij Sojuz v XXI veke: vremja ispytanij [The European Union in the XXI Century: testing time] / Ed. by O.Ju. Potjomkina, N.Ju. Kaveshnikov, N.B. Kodrat'eva. M.: Ves' mir, 2012].

Журкин В.В. Европейская армия: поражения и победы. М.: Международные отношения, 2012 [Zhurkin V.V. Evropejskaja armija: porazhenija i pobedy [The European Army: traumas and vicktories]. M.: Mezhdunarodnye otnoshenija, 2012].

Игумнова Л.О. Цели и мотивы Европейского союза как антрепренёра норм // Вестник Томского государственного университета. 2012. №1 (17). С. 80-88. http://journals.tsu.ru/uploads/import/423/files/17-080.pdf [Igumnova L.O. Celi i motivy Evropejskogo sojuza kak anterprenjora norm [Aims and motives of the European Union in advancement of norms] // Vestnik Tomskogo gosudarstvennogo universiteta. 2012. №1 (17). S. 80-88].

Исполинов А.С. Суд Европейского Союза против присоединения ЕС к Европейской конвенции по правам человека (причины и следствия) // Международное правосудие. 2015. №1. C. 118-134. [Ispolinov A.S. Sud Evropejskogo Sojuza protiv prisoedinenija ES k Evropejskoj konvencii po pravam cheloveka (prichiny i sledstvija) [The Court of the EU against the EU joining the European Convention on Human Rights] // Mezhdunarodnoe pravosudie. $2015 . \quad$ №1] URL: http://www.ilpp.ru/netcat_files/userfiles/MP_Archiv/MP1(13)2015_ContentsRUS.pdf.

Кавешников Н.Ю. Многоликая энергетическая безопасность // Международная жизнь. Декабрь 2011. C. 88-103 [Kaveshnikov N.Ju. Mnogolikaja jenergeticheskaja bezopasnost' [multifaced energy security] // Mezhdunarodnaja zhizn'. Dekabr' 2011. S. 88-103].

Конопляник А. Вхождение Украины в Договор об Энергетическом сообществе ЕС со странами Юго-Восточной Европы: последствия для всех заинтересованных сторон // Нефть и газ. 2010. № 6. С. 20-36 []Konopljanik A. Vhozhdenie Ukrainy v Dogovor ob Jenergeticheskom soobshhestve ES so stranami Jugo-Vostochnoj Evropy: posledstvija dlja vseh zainteresovannyh storon[Entry of Ukraine to the Energy Community Agreement between the EU and countries of South East Europe: consequences for all interested parties] // Neft' i gaz. 2010. № 6. S. 20-36].

Конышев В.Н., Сергунин А.А. Международные организации и сотрудничество в Арктике // Вестник международных организащий. 2011. №3(34). C. 27-36. [Konyshev V.N., Sergunin A.A.Mezhdunarodnye organizacii i sotrudnichestvo v Arktike // Vestnik mezhdunarodnyh organizacij. $2011 . \quad$ №3(34)]. https://iorj.hse.ru/data/2011/09/08/1267018862/4.pdf.

Миронов В.В. «Новое Средневековье» в концепциях представителей английской школы теории международных отношений // Вестник Омского университета. Серия «Исторические науки». 2015. № 2 (6). C. 23-29 [Mironov V.V. «Novoe Srednevekov'e» v koncepcijah predstavitelej anglijskoj shkoly teorii mezhdunarodnyh otnoshenij ["New Middle Ages" in the concepts of the representatives of the English school in the international relations] // Vestnik Omskogo universiteta. Serija «Istoricheskie nauki». 2015. № 2 (6).

S. 23-29].

Подбиралина Г.В. Организационные и экономические аспекты сотрудничества ЕС и африканских стран // Вестник РЭА. 2008. № 1. P. 103-107 [Podbiralina G.V. Organizacionnye i jekonomicheskie aspekty sotrudnichestva ES i afrikanskih stran [Organisational and economic aspects of cooperation of the EU with African countries] // Vestnik RJeA. 2008. № 1. S. 103-107]. 
Потёмкина Ольга. «Новое партнёрство» Комиссии ЕС - «амбициозный план» с неясными перспективами // Аналитическая записка №31 Института Европы РАН. 2016 (№61). C. 3-4. URL: http://instituteofeurope.ru/images/uploads/analitika/an61.pdf [Potjomkina Ol'ga. «Novoe partnjorstvo» Komissii ES - «ambicioznyj plan» s nejasnymi perspektivami ["New Partnership" of the European Commission - an ambitious plan with unclear perspective] // Analiticheskaja zapiska №31 Instituta Evropy RAN. 2016 (№61). S. 3-4].

Прохоренко И.Л. Глобальная роль Евросоюза: что и как объясняет организационная теория // Вестник Пермского университета. Серия: Политология. 2015. № 2. С. 5-17 [Prohorenko I.L. Global'naja rol' Evrosojuza: chto i kak ob\#jasnjaet organizacionnaja teorija [The global role of the European Union: what can be explained with the help of the organization theory] // Vestnik Permskogo universiteta. Serija: Politologija. 2015. № 2. S. 5-17].

Прохоренко И.Л. Организационная теория в анализе глобального управления // Вестник Московского университета. Серия 25. Международные отношения и мировая политика. 2014. № 3. С. 150-173 [Prohorenko I.L. Organizacionnaja teorija v analize global'nogo upravlenija [The organisation in the analysis of global governance] // Vestnik Moskovskogo universiteta. Serija 25.Mezhdunarodnye otnoshenija i mirovaja politika. 2014. № 3. S. 150-173].

РасширениеЕвропейскогосоюзаиРоссия / Подред. О.В. Буториной, Ю.А. Борко. М., 2006 [Rasshirenie Evropejskogo sojuza i Rossija [Enlargement of the European Union and Russia] / Pod red.O.V. Butorinoj, Ju.A. Borko. M., 2006].

Романова T.A. Евросоюз как нормативная сила и проблемы ее восприятия в России как барьер на пути политико-правового сближения // Вестник Санкт-Петербургского университета. Сер. 6. 2011. Вып. 1. С. 52-66 [Romanova T.A. Evrosojuz kak normativnaja sila i problemy ee vosprijatija v Rossii kak bar'er na puti politiko-pravovogo sblizhenija [The European Union as a normative power and problems of its perception in Russia as a barrier to the political and legal rapprochement] // Vestnik Sankt-Peterburgskogo universiteta. Ser. 6. 2011. No. 1, pp. 52-66].

Саликов А.Н. Интерпретация идей трактата «К вечному миру» И. Канта в современной либеральной теории демократического мира // Кантовский сборник. №4 (42). 2012. С. 42-49 [Salikov A.N. Interpretacija idej traktata «K vechnomu miru» I. Kanta v sovremennoj liberal'noj teorii demokraticheskogo mira [The interpretation of the ideas of the essay "Perpetual Peace" by I. Kant in the modern liberal theory of the democratic peace] // Kantovskij sbornik. №4 (42). 2012. S. 42-49].

Стрежнева М.В. Европейский союз: Инвестиционный план Жан-Клода Юнкера // Год планеты: экономика, политика, безопасность. Ежегодник. Выпуск 2015 г. С. 220 231 Strezhneva M.V. Evropejskij sojuz: Investicionnyj plan Zhan-Kloda Junkera [The European Union: the investment plan of J.-C.Juncker] // God planety: jekonomika, politika, bezopasnost'. Ezhegodnik. Vypusk 2015 g. S. 220-231].

Стрежнева М.В. Территориальный и функциональны типы организации политических пространств (в развитие интеграционной теории) // Политическая наука. 2014. №2. С. 32-43 [Strezhneva M.V. Territorial'nyj i funkcional'ny tipy organizacii politicheskih prostranstv (v razvitie integracionnoj teorii) [Territorial and functional types of organizing the political space (in elaboration of integration theory)] // Politicheskaja nauka. 2014. №2, S. 32-43].

Стрежнева М.В. Условия партнерства с Европейским союзом // Мировая экономика $u$ международные отношения. 2007. № 6. C. 3-13 [Strezhneva M.V. Uslovija partnerstva s Evropejskim sojuzom [Conditions for partnership with the European Union] // Mirovaja jekonomika i mezhdunarodnye otnoshenija. 2007. № 6. S. 3-13]. 
Трофимова О.Е. Эволюиия средиземноморской политики Евросоюза: путь от сотрудничества к интеграции. М.: ИМЭМО, 2011. 122 с. [Trofimova O.E. Jevoljucija sredizemnomorskoj politiki Evrosojuza: put' ot sotrudnichestva k integracii [The evolution of the EU policy in the Mediterranean: from cooperation to integration]. M.: IMJeMO, 2011. 122 s.].URL: http://www.imemo.ru/files/File/ru/publ/2011/11006.pdf.

Хиллион Кристоф, Блокманс Стивен. Самооборона Европы: один за всех и все за одного? // Журнал международного права и международных отношений. 2015. № 4. [Hillion Kristof, Blokmans Stiven. Samooborona Evropy: odin za vseh i vse za odnogo? [European self-defense: one together and all for one?] //Zhurnal mezhdunarodnogo prava i mezhdunarodnyh otnoshenij. $2015 . \quad$ №4]. http://www.evolutio.info/content/view/2447/235.

Цветков А.Ю. Публичная дипломатия как ресурс внешней политики: проблема эффективности // Вестник СПбГУ. Сер. 6, 2000, вып.3. С. 110-116 [Cvetkov A.Ju. Publichnaja diplomatija kak resurs vneshnej politiki problema jeffektivnosti [Public diplomacy as a resource of foreign policy: the effectiveness problem] // Vestnik SPbGU. Ser. 6, 2000, vyp.3. S. 110-116].

Abdelal Rawi and Krotz Ulrich. Disjoining Partners: Europe and the American Imperium // Power in a Complex Global System / Ed. by Louis W. Pauly and Bruce W. Jentleson. London: Routledge, 2014. P. 131-147.

Ahrne G., Brunsson N. How much do meta-organizations affect their members? // Paper presented at SGIR 7th Pan-European International Relations Conference, Stockholm, 9-11 September 2010. URL: http://www.eisa-net.org/be-bruga/eisa/files/events/stockholm/Metaorganizations.pdf.

Ahrne G., Brunsson N. Meta-organizations. Cheltenham: Edward Elgar Publishing, 2008. 200 p.

Ahrne G., Brunsson N. Organizations and Meta-Organizations // Scandinavian Journal of Management. 2005. Vol. 21. № 4. P. 429-249.

Balding Ch., Wehrenfennig D. An Organizational Theory of International Institutions // Journal of International Organizations Studies. 2011. Vol. 2. № 1. P. 7-27. URL: http://journaliostudies.org/sites/journal-iostudies.org/files/JIOS201121final_3.pdf.

Balfour R. EU Conditionality after the Arab Spring. 2012. [Electronic resource]. - Mode of access: http://www.epc.eu/documents/uploads/pub_2728_papersbalfour_for_euromesco16.pdf.

Balfour R., Raik K. The EEAS and national diplomacies // European Policy Centre Paper. 2013. № 73. 187

p.

URL: http://www.epc.eu/documents/uploads/pub_3385_the_eeas_and_national_diplomacies.pdf.

Barkin J.S. International Organization: Theories and Institutions. London: Palgrave Macmillan, 2006. 185 p. URL: https://stackofideas.files.wordpress.com/2012/02/jsamuel_barkin_international_organization_thebookfi-org.pdf.

Bartelt ${ }^{-}$. The Institutional Interplay Regarding the New Architecture for the EC's External Assistance // European Law Journal. 2008. Vol. 14. № 5. P. 655-679.

Bátora J. The 'Mitrailleuse Effect': The EEAS as an Interstitial Organization and the Dynamics of Innovation in Diplomacy // Journal of Common Market Studies. 2013. №51(4). P. 598-613.

Berridge G.R. and James Alan. A Dictionary of Diplomacy, vol. 2. New York: Palgrave Macmillan, 2003.

Bickerton J., Hodson D., Puetter U. The New Intergovernmentalism: European Integration in the Post-Maastricht Era // Journal of Common Market Studies. 2014. Vol.53. № 4. P. 703-722. URL: http://eprints.bbk.ac.uk/11050/1/NI\%20JCMS\%20Pre-Pub\%20(2).pdf.

Bienen H.S., Gersovitz M. Economic Stabilisation, Conditionality and Political Stability // International Organization. 1985. Vol. 39. № 4. P. 729-754. 
Biscop Sven. The EU Global Strategy: Realpolitik with European Characteristics // ESecurity Policy Brief. 2016. № 75. June 2016. P. 1-6/ URL: http://www.egmontinstitute.be/wpcontent/uploads/2016/06/SPB75.pdf.

Blockmans S. Ukraine, Russia and the need for more flexibility in EU foreign policy-making // CEPS Policy Brief. 2014. № 320. URL: https://www.ceps.eu/publications/ukraine-russiaand-need-more-flexibility-eu-foreign-policy-making.

Chou M.H., Riddervold M. The Unexpected Negotiator at the Table: How the European Commission's Expertise Informs Intergovernmental EU Policies // Politics and Governance. 2015. Vol.3. № 1. P. 61-72.

Cohen Stephen B. Conditioning US Security Assistance on Human Rights Practices // American Journal of International Law. 1982. Vol. 76. P. 246-279.

Corthaut T., Van Eeckhoutte D. Legal Aspects of EU Participation in Global Environmental Governance under the UN Umbrella // The European Union and Multilateral Governance / Ed. by J. Wouters, H. Bruyninckx, S. Basu, S. Schunz. 2012. P. 145-170.

Crawford G. Foreign Aid and Political Reform: A Comparative Analysis of Democracy Assistance and Political Conditionality. Basingstoke, UK/New York: Palgrave, 2001. 293 p.

Davidson N. U.S. Secondary Sanctions: the U.K. and EU Response// Stetson Law Review. 1998.

№ 27. P. 1425-1435. URL: http://www.stetson.edu/law/lawreview/media/u-s-secondary-sanctionsthe-u-k-and-e-u-response.pdf.

Dearden S. EU Development Policy: Delivering Aid Effectiveness // Jean Monnet/Robert Schuman Paper Series. 2008. Vol. 8, № 10.48 p. $\quad$ URL: http://aei.pitt.edu/9008/1/DeardenEUdevelopmentLong08edi.pdf.

De Cordier Bruno. The EU's humanitarian aid and civil protection policy in Central Asia: Past crises and emergencies to come // EUCAM Policy Brief, № 29, January 2013. URL: http://www.eucentralasia.eu/uploads/tx_icticontent/EUCAM-PB-29-EN-EU-HumanitarianAid.pdf.

Duchêne F. The European Community and the Uncertainties of Interdependence // A Nation Writ Large? Foreign-Policy Problems before the European Community / Ed. by $\mathrm{H}$. Kohnstammand W. Hager. London: Macmillan Press, 1973. P. 1-21.

Duffield J. The Limits of 'Rational Design' // International Organization. 2003. Vol. 57. № 2. P. 411-430.

Duke S. The European External Action Service and Public Diplomacy // Discussion Papers in Diplomacy. Clingendael, Netherlands Institute of International Relations. The Hague, 2013. $44 \mathrm{p}$.

Egeberg M. Multilevel Union Administration: The Transformation of Executive Politics in Europe. Houndsmills: Palgrave Macmillan, 2006. 228 p.

Eckes Christina. EU Counter-Terrorist Sanctions against Individuals: Problems and Perils // European Foreign Affairs Review. 2012. Vol. 17. № 1. P. 113-132.

Erkelens L., Blockmans S. Setting up the European External Action Service: an Institutional Act of Balance // CLEER Working Papers, 2012. №1. URL: http://www.asser.n1/media/1630/cleer2012-1web.pdf.

Fabbrini S. From Consensus to Domination: The Intergovernmental Union in a Crisis Situation // Journal of European Integration. 2016. Vol. 38. № 5. P. 587-599.

Fallon T. Europe's 'Principled Pragmatism' on the South China Sea // RUSI. 12.07.2016. [Electronic resource]. Mode of access: https://rusi.org/commentary/europe $\%$ E2\%80\%99s$\%$ E2\%80\%98principled-pragmatism $\%$ E2\%80\%99-south-china-sea.

Fierro E. The EU's Approach to Human Rights Conditionality in Practice. The Hague: Kluwer Law International, 2002. $448 \mathrm{p}$.

Fouéré E. The EU Special Representatives: A dwindling but resilient resource at the service of EU Foreign and Security Policy // CEPS Policy Brief. 2016. № 348. 12 p. 
Galbert S de. Transatlantic Economic Statecraft. The Challenge to Building a Balanced Transatlantic Sanctions Policy between the United States and the European Union. 2016. P. 5. [Electronic resource]. Mode of access: https://csis-prod.s3.amazonaws.com/s3fspublic/publication/160621_CNASReport_Economic_State.pdf.

Ganzle S. Coping with the 'Security-Development Nexus': The European Community's Instrument for Stability Rationale and Potential. Bonn: German Development Institute, 2009. URL: http://edoc.vifapol.de/opus/volltexte/2013/4387/pdf/Studies_47.2009.pdfю

Gaenzle S. Policy-making and New Modes of Governance in the European Neighborhood Policy // Jean Monnet/Robert Schuman Paper Series. 2008.Vol. 8 № 8.18 p.

Giumelli Francesco. How EU Sanctions Work: A New Narrative//Chaillot Papers. May 2013.

No 129. URL: http://www.iss.europa.eu/uploads/media/Chaillot_129.pdf.

Giumelli F., Ivan P. The effectiveness of EU sanctions. An analysis of Iran, Belarus, Syria and Myanmar (Burma) // EPC Issue Paper. 2013. № 76. P. 18. URL: http://www.epc.eu/documents/uploads/pub_3928_epc_issue_paper_76_the effectiveness of eu sanctions.pdf.

Hamilton Keith and Langhome Richard. The Practice of Diplomacy: Its Evolution, Theory and Administration, 2nd Edition. New York: Routledge, 2011.

Hannan M. T., Freeman J. H. 1977. The Population Ecology of Organizations //American Journal of Sociology. Vol. 82. P. 929-964.

Hazelzet H. Suspension of Development Co-operation: An Instrument to Promote Human Rights and Democracy? // European Centre for Development Policy Management (ECDPM) Discussion Paper. 2005. №. 64B. 23 p. URL: http://global.wisc.edu/development/resources/clayton-hazelzet.pdf.

Heath Ryan. Juncker in trouble - Brexit - EEAS' Le Roy resigns // Politico. 16.06.2016. [Electronic resource]. Mode of access: http://www.politico.eu/newsletter/playbook/politicobrussels-playbook-presented-by-qualcomm-juncker-in-trouble-brexit-eeas-le-roy-resigns.

Hettne B., Söderbaum F. Civilian Power or Soft Imperialism? EU as a Global Actor and the Role of Interregionalism // European Foreign Affairs Review. 2005. Vol. 10. № 4. P. 535-552.

Hill Ch. Cheques and Balances: The European Union's Soft Power Strategy / Soft Power and US Foreign Policy: Theoretical, Historical and Contemporary Perspectives // Ed. by I. Parmar, M. Cox. - London: Routledge, 2010. P. 182-199.

Hill Ch. The Changing Politics of Foreign Policy. London: Palgrave Macmillan, 2003. 416 p.

Hillion Ch. A Powerless Court? The European Court of Justice and the EU Common Foreign and Security Policy. January 30, 2014. [Electronic resource]. Mode of access: http://ssrn.com/abstract=2388165 or http://dx.doi.org/10.2139/ssrn.2388165.

Hillion Ch. Integrating an Outsider: An EU Perspective on Relations with Norway // Europautredningen, Rapport №16. 2001. [Electronic resource]. - Mode of access: http://www.europautredningen.no/wp-content/uploads/2011/04/Rap16-E\%C3\%98S-sett-fraEU.pdf.

Hooghe L., Marks G. Multi-level Governance and European Integration. Lanham, Maryland: Rowman \& Littlefield, 2001.

Hufbauer G. C., Schott J. J., Elliott K. A. and Oegg B. Economic Sanctions Reconsidered, 3rd ed., Washington, D.C.: Peterson Institute for International Economics, 2007.

Kelley J. New Wine in Old Wineskins: Promoting Political Reforms through the New European Neighbourhood Policy // Journal of Common Market Studies. 2006. Vol. 44. № 1. P. 29-55.

Kelley J. International Actors on the Domestic Scene: Membership Conditionality and Socialization by International Institutions // International Organization. 2004. Vol.58. Issue 3. P. 425457.

Keohane R.O. Multilateralism: An Agenda for Research // International Journal. 1990.Vol. 45. № 4. P. 731-764. 
Kern A. Economic Sanctions: Law and Public Policy. London: Palgrave Macmillan, 2009.

Kerr P., Wiseman G., eds. Diplomacy in a Globalizing World: Theories and Practices. Oxford, New York: Oxford University Press, 2013.

Kerwer D. International organizations as meta-organizations: The case of the European Union //Journal of International Organizations Studies. 2013. № 4. P. 40-53. URL:

http://journal-iostudies.org/sites/journal-iostudies.org/files/JIOS2013-special-issue Kerwer.pdf.

Keukeleire S., Delreux T. The Foreign Policy of the European Union. Palgrave Macmillan, 2014. $408 \mathrm{p}$.

Koenig N. The EU and the Libyan Crisis: In Quest of Coherence? // Istituto Affari Internazionali Working Papers, July 2011. URL: http://www.iai.it/sites/default/files/iaiwp1119.pdf

Lasocki J. How EU conditionality is helping to transform Ukraine// European Council on Foreign Relations. Commentary. 22.03.2016. [Electronic resource]. - Mode of access: http://www.ecfr.eu/article/commentary_how_eu_conditionality_is_helping_to_transform_uk raine6046.

Lavenex S., Schimmelfennig F. EU rules beyond EU borders: theorizing external governance in European policy //Journal of European Public Policy. 2009. Vol. 16. Issue 6. P. 791-812. URL: http://www.tandfonline.com/doi/pdf/10.1080/13501760903087696.

Manners I. Sciology of Knowledge and Production of Normative Power in the European Union's External Actions // Journal of European Integration. 2015. Vol. 37. № 2. P. 299-318.

Manners I. The EU's Normative Power in Changing World Politics // Normative Power Europe in a Changing World: a Discussion / Ed. by André Gerrits. Netherlands Institute of International Relations, 2009.

URL: http://www.clingendael.nl/sites/default/files/20091200 cesp paper_gerrits.pdf.

Manners I. Normative Power Europe: A Contradiction in Terms // Journal of Common Market Studies. 2002. Vol. 40. № 2. P. 235-258.

March J.G., Olsen J.P. The New Institutionalism: Organizational Factors in Political Life // The American Political Science Review. 1984. Vol. 78. № 3. P. 734-749.

Meloni A. EU Visa Policy and Conditionality: A Two Way Road// Europe as A Global Actor. Conference Paper. 2016. [Electronic resource]. Mode of access: http://cei.iscteiul.pt/europeglobalactor/eu-visa-policy-and-conditionality-a-two-way-road/

Meloni G. Is the same toolkit used during enlargement still applicable to the Countries of the New Neighbourhood? A problem of mismatching between objectives and instruments // Workshop paper. European University Instituite, 2006. URL: http://www.eui.eu/Documents/DepartmentsCentres/Law/Professors/Cremona/TheEuropean NeighbourhoodPolicy/PaperMeloni.pdf.

Meunier S., Nicolaidis K. The European Union as a conflicted trade power. International relations and the European Union. New York: Oxford University Press, 2011.

Meunier S., Nicolaidis K. The European Union as a conflicted trade power // Journal of European Public Policy. 2006. Vol. 13. № 6. P. 906-925. URL: http://scholar.princeton.edu/sites/default/files/meuniernicolaidisjepp2006_0.pdf.

Meyer J. W., Rowan B. Institutionalized Organizations: Formal Structure as Myth and Ceremony // American Journal of Sociology. 1977. Vol. 83. N 2. P. 340-363.

Monar Jörg. The Rejection of the EU-US SWIFT Interim Agreement by the European Parliament: A Historic Vote and Its Implications // European Foreign Affairs Review. 2010. Vol. 15. P. 143-151.

Murdoch Z. Organization Theory and the Study of European Union Institutions: Lessons and Opportunities // Organization Studies. 2015. Vol. 36. P. 1675-1692. URL: http://oss.sagepub.com/content/36/12/1675.full.pdf+html.

Murdoch Zuzana, Jarle Trondal and Gänzle Stefan. The Origins of Common Action Capacities in EU Foreign Policy. Observations on the recruitment of Member States' diplomats and 
officials to the European External Action Service (EEAS) // ARENA Working Paper. No. 1, March 2013. URL: http://www.sv.uio.no/arena/english/research/publications/arena-workingpapers/2013/wp1-13.pdf.

Nye J. S., Jr. Soft Power: The Means to Success in World Politics. New York: Public Affairs, 2004. $191 \mathrm{p}$.

Olsen J.P. Change and Continuity: An Institutional Approach to Institutions of Democratic Government // European Political Science Review. 2009. Vol.1. № 1. P.3-32.

Peters B.G. Institutional theory // The Sage Handbook of Governance / Ed. by M. Bevir. London: SAGE Publications, 2011.

Peterson J., Bouchard C. Making Multilateralism Effective: Modernising Global Governance // Multilateralism in the 21st Century. Europe's Quest for Effectiveness / Ed. by C. Bouchard, J. Peterson, N. Tocci. London, New York: Routledge, 2014, pp. 13-38.

Poli Sara, ed. The European Neighbourhood Policy - Values and Principles. London and New York: Routledge, 2016.

Pomorska K., Juncos A. Manufacturing 'esprit de corps': the case of the European External Action Service // Journal of Common Market Studies. 2014. Vol. 52. №. 2. P. 302-319.

Portela C.The EU's Use of 'Targeted' Sanctions: Evaluating effectiveness // CEPS Working Document. March 2014. № 391.

Prytula N.V. Instruments of Foreign Trade Policy of the European Union // ECONOMICS: time realities. 2015. No2 (18). URL: http://cyberleninka.ru/article/n/instruments-of-foreign-tradepolicy-of-the-european-union.

Puetter U. The European Council and the Council: New Intergovernmentalism and Institutional Change. Oxford: Oxford University Press, 2014. 288 p.

Rathbone M., Jeydel P., Lentz A. Sanctions, Sanctions Everywhere: Forging a Path Through Complex Transnational Sanctions Laws // Georgetown Journal of International Law. 2013. Vol. 44. P. 1055-1126. URL: https://www.law.georgetown.edu/academics/lawjournals/gjil/recent/upload/zsx00313001055.PDF.

Ruggie J.G. Multilateralism: The Anatomy of an Institution // International Organization. 1992. Vol. 46. № 3. P. 561-598.

Salmon T., Shepherd J.K.A. Toward a European Army: A Military Power in the Making? Denver: Lynne Rienner Pub., 2003.

Schimmelfennig F., Engert S., Knobel H. Cost, Commitment and Compliance: the Impact of EU Democratic Conditionality on Latvia, Slovakia and Turkey // Journal of Common Market Studies. 2003. Vol. 41. № 3. P. 495-518.

Schimmelfennig Frank. International Socialization in the New Europe: Rational Action in an Institutional Environment // European Journal of International Relations. 2000. No 6(1), pp. 109-139.

Schunnemann Julia. EU conflict prevention 10 years after Göteborg: Front-runner or lame duck? 10 years from the EU Programme for Conflict prevention // Policy Paper of the Institut Catalana Internacional per la Pau. June 2011. № 01. URL: https://www.academia.edu/1406975/EU_conflict_prevention_10_years_after_G\%C3\%B6te borg_Front-

runner_or_lame_duck_10_years_on_from_the_UE_Programme_for_Conflict_Prevention.

Shyla K., Yahorau A. Civil society's role and place in the system of the EU' Belarus // Working paper. Center for European Transformation, 2013. http://cet.eurobelarus.info/files/File/Aid-Assistance-WD_EN.pdf.

Smith K.E. The Use of Political Conditionality in the EU's Relations with Third Countries: How Effective? // European Foreign Affairs Review. 1998.Vol. 3. № 2. P. 253-274.

Smith M. Foreign policy and development in the post-Lisbon European Union // Cambridge Review of International Affairs. 2013. Vol. 26, No. 3. P. 519-535. 
Smith M. Toward a theory of EU foreign policy-making: multi-level governance, domestic politics, and national adaptation to Europe's common foreign and security policy // Journal of European Public Policy. 2004. Vol. 11(4). P. 740-758.

Stiglitz J.E. Globalization and its Discontents. New York, 2002. 304 p.

Szołucha Anna. The EU and Enlargement Fatigue: Why has the European Union not been able to counter enlargement fatigue? // Journal of Contemporary European Research. Volume 6, Issue 1. URL: http://www.jcer.net/index.php/jcer/article/view/124/192.

The European Union as a Diplomatic Actor / Ed. by Joachim A. Koops and Gjovalin Macaj. London: Palgrave Macmillan, 2015.

Thym Daniel. The Intergovernmental Constitution of the EU's Foreign, Security \& Defence Executive // European Constitutional Law Review, Volume 7, Issue 3 October 2011, pp. 453-480.

Tostensen A., Bull B. Are Smart Sanctions Feasible? // World Politics. 2002. Vol. 54. № 3. P. 373403.

Tridimas T., Nebbia P. European Union Law for the Twenty-First Century: Rethinking the New Legal Order. Vol. 1: Constitutional and Public Law. External Relations. Oxford: Hart Publishing, 2004.

Tulmets E. Adapting the Experience of Enlargement to the Neighbourhood Policy: The ENP as a Substitute to Enlargement? / The EU and its Neighbourhood: Policies, Problems, Priorities/ Ed. by P. Kratochvíl. Prague: Institute of International Relations, 2006. P. 29-57.

Turkmani R., Haid M. The role of the EU in the Syrian conflict // Paper commissioned by the Human Security Study Group. February 2016, London. P. 16. [Electronic resource]. Mode of access: http://www.feslondon.org.uk/cms/files/fes/img/publications/FES_LSE_Syria_Turkmani_Ha id_2016\%2002\%2023.pdf.

Vines A. The effectiveness of UN and EU sanctions: Lessons for the twenty-first century // International Affairs. 2012. Vol. 88. №. 4. P. 867-877.

Wessels W., Bopp F. The institutional architecture of CFSP after the Lisbon Treaty: constitutional breakthrough or challenges ahead? // CEPS Challenge Paper. № 10. 2008. URL: https://www.ceps.eu/system/files/book/1677.pdf.

Whitman R.G., Wolff S. The European Union as a Global Conflict Manager. London: Routledge, 2012. P. 156.

Wisniewski Elisabeth. The Influence of the European Parliament on the European External Action Service // European Foreign Affairs Review. 2013. Vol. 18. № 1. P. 81-101

Wood S. The European Union: a normative or normal power? // European Foreign Affairs Review. 2009. Vol. 14. № 1. P. 113-128.

Youngs R. Fine-Tuning EU Support for Ukrainian Democratization // Policy Outlook. 06.04.2016. [Electronic resource]. Mode of access: http://carnegieeurope.eu/publications/?fa=63250.

Zielonka J. Europe as Empire: The Nature of the Enlarged European Union. Oxford University Press, $2007.304 \mathrm{p}$.

Zwan J. Evaluating the EU's Role and Challenges in Sudan and South Sudan: Sudan and South Sudan Case Study // International Alert. London, 2011. URL: http:/www.internationalalert.org/sites/default/files/publications/092011 IfPEWSudan_0.pdf. 
Научное издание

Стрежнева Марина Вадимовна

Руденкова Дарьл Эдуардовна

Европейский союз: архитектура внешней политики

Монография

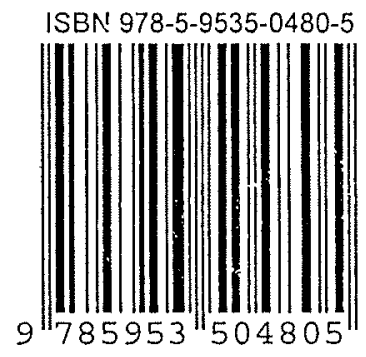

Подписано в печать 14.12.2016.

Формат 60×84/8.Печать офсетная.

Объем 17 п.л., 11 а.л. Тираж 250 экз. Заказ № 45/2016

Издательство ИМЭМО РАН

Адрес: 117997, Москва, Профсоюзная ул., 23 